\title{
DISTRIBUIÇÃO DA DIVERSIDAdE GENÉTICA E CORRELAÇÕES DE CARACTERES EM ETNOVARIEDADES DE MANDIOCA (Manihot esculenta, Crantz) PROVENIENTES DA AGRICULTURA TRADICIONAL DO BRASIL
}

\section{ROBERTO CURY}

Engenheiro Agrônomo

Orientador: Prof. Dr. AKIHIKO ANDO

Tese apresentada ̀̀ Escola Superior de Agricultura "Luiz de Queiroz". Universidade de São Pauld. para obtenção do título de Doutor em Agronomia. Área de Concentração: Genética e Melhoramento de Plantas.

\section{PIRACICABA}

Estado de São Paulo - Brasil

Maio -1998 
Dados Internacionais de Catalogação na Publicação (CIP) DIVISĀo DE BIBLIOTECA E DOCUMENTAÇĀO - Campus "Luiz de Queiroz"/USP

\section{Cury, Roberto}

Distribuição da diversidade genética e correlaçōes de caracteres em etnovariedades de mandioca (Manihor esculenta, Crantz) provenientes da agricultura tradicional do Brasil / Roberto Cury, 1998.

$163 \mathrm{p}$.

Tese (doutorado) - - Escola Superior de Agricultura Luiz de Queiroz, 1998.

Bibliografia.

1. Agricultura tradicional 2. Diversidade genética 3. Ennobotânica 4. Mandioca 5. Melhoramento genético vegetal 6 . Variedade I. Titulo 
Este trabalho é uma homenagem ao Prof Dr Paulo Sodero Martins, um dos maiores evolucionistas brasileiros deste século. 


\section{AGRADECIMENTOS}

to Prof. Dr. Akihiko Ando, pela orientação.

A Prof. ${ }^{3}$ Dr. ${ }^{3}$ Mamey Pascoli Cereda pelo apoio e sugestões.

to Prof. Dr. Roland Vencovsky, pelo apoio nas análises biométricas.

to Dr Nelson da Silva Fonseca Júnior pelo apoio nas análises estatísticas.

to Ronaldo J. Rabello pelo apoio em todas as fases do ensaio.

A todos os funcionários da estação experimental do Anhembi, em especial ao Zé Monteiro. pela competente condução do ensaio de campo.

A todos colegas do curso de pós graduação em genética e melhoramento, em especial aos colegas Beti, Inèz, Rainerio, Nivaldo, Gilda, Fábio, Geraldo, Juliano, Ednei e Elias.

Ao Centro de Raizes Tropicais (CERAT), da UNESP / Botucatu, em especial aos técnicos Francisco Rossi e Luíz Henrique Urbano, pela realização das análises laboratoriais.

Ao CNPQ, pela bolsa de estudos concedida.

A minha esposa Neusa, por permitir minha ausência nestes dias. 


\section{SUMÁRIO}

RESUMO VI

SUMMARY VIII

1. INTRODUÇÃO 1

2. REVISÃO DE LITERATURA 4

2.1. A Mandioca 4

2.1.1. O gènero Manihot, Mill 4

2.1.2. Citogenética 5

2.1.3. Genetica 7

2.1.4. Domesticação 9

2.2. Composição quimica da mandioca 14

2.2.1. Composição das raizes da mandioca. 14

2.2.2. Composição das folhas da mandioca 16

2.2.3. Composição do caule da mandioca 17

2.2.4. O ácido cianidrico na mandioca. 17

3. MATERIAL E MÉTODOS 21

3.1. Material 21

3.2. Ensaio de campo 22

3.3. Caracterização do material 22

3.3.1 Caracteristicas morfológicas $\quad 22$

3.3.2. Características agronòmicas 25

3.3.3. Caracteristicas quimicas. 25

3.4. Avaliação e amostragem $\quad 27$

3.5. Metodologias utilizadas nas análises quimicas. 28

3.6. Análises estatísticas. 29

3.6.1. Análise de variância dos descritores com distribuição contínua 29

3.6.1.1. Análise geral, segundo modelo simplificado 29

3.6.1.2 Desdobramentos da naálise de variància. 31

3.6.2. Estimativas da divergência genética multivariada entre as 
etnovariedades.

4. RESULTADOS E DISCUSSÃO 36

4.1. Caracterização das etnovariedades 36

4.1.1. Caracterização morfológica 36

4.1.2. Caracterização agronômica 38

4.1.2.1. Produção de raizes, em kg/pl 38

4.1.2.2. Peso da parte aérea, em kg/pl 40

4.1.2.3. Indice de colheita 41

4.1.2.4. Número de raízes $\quad 42$

4.1.2.5. Produção de amido, $\mathrm{Kg} / \mathrm{pl}$. 43

4.1.2.6. Relação com a domesticação da mandioca da variabilidade e herança dos caracteres agronômicos $\quad 44$

4.1.3. Caracterização química: ácido cianídrico 45

4.1.3.1. Potencial cianogènico e teor de ácido cianídrico livre nas folhas, $\mathrm{mg} / \mathrm{kg}$ na base seca $\quad 45$

4.1.3.2. Potencial cianogènico na entrecasca e na polpa das raízes, 46 $\mathrm{mg} / \mathrm{kg}$ na base seca

4.1.3.3. Ácido cianídrico livre na entrecasca e na polpa das raizes 49

4.1.3.4. Relação com a domesticação da mandioca do potencial cianogènico nas raizes $\quad 50$

4.1.4. Caracterização química: folhas 51

4.1.4.1. Matéria seca nas folhas, em \% 51

4.1.4.2. Teor de proteinas nas folhas, em \% da matéria seca 52

4.1.4.3. Teor matéria graxa nas folhas, em \% da matéria seca 53

4.1.4.4. Teor de cinzas nas folhas, em \% da matéria seca 54

4.1.4.5. Teor de fibras nas folhas, em \% da matéria seca 54

4.1.4.6. Teor de carboidratos nas folhas, em \% da matéria seca 55

4.1.4.7. Relação com a domesticação da mandioca dos componentes químicos das folhas 
4.1.5. Caracteristicas químicas: Caule 56

4.1.5.1. Teor de umidade no caule, em \% 56

4.1.5.2. Teor de cinzas no caule, em \% da matéria seca 57

4. 1.5.3. Teor de proteínas no caule, em \% da matéria seca 58

4.1.5.4. Teor de fibras no caule, em \% da matéria seca 60

4.1.5.5. Teor de matéria graxa no caule, em \% da matéria seca 60

4.1.5.6. Teor de carboidratos totais no caule, em \% da matéria seca 61

4.1.5.7. Relação com a domesticação da mandioca dos componentes químicos do caule $\quad 62$

4.1.6. Caracteristicas quimicas: Raiz 63

4.1.6.1. Teores de umidade nas raizes, em \% 63

4.1.6.2. Teor de proteina nas raizes, em \% da matéria seca 64

4.1.6.3. Teor de amido (fécula) nas raizes, em \% da matéria seca 65

4.1.6.4. Teor de matéria graxa nas raízes, em \% da matéria seca 67

4.1.6.5. Teor de cinzas nas raizes, em \% da matéria seca 68

4.1.6.6. Teor de fibras nas raízes, em \% da matéria seca 69

4.1.6.7. Teor de açúcar solúvel nas raizes, em \% da matéria seca 70

4.1.6.8 Relação com a domesticação da mandioca dos componentes químicos da raiz $\quad 71$

4.2. Associação genética dos descritores e domesticação 71

4.3. Distribuição da variabilidade genética com base na análise univariada dos descritores $\quad 75$

4.4. Divergência genética multivariada 79

4.4.1. Divergência genética por variáveis canônicas 79

4.4.2. Divergência genética por distância de Mahalanobis 81

5. CONCLUSÕES 83

REFERÊNCIAS BIBLIOGRÁFICAS

Figuras 96

$\begin{array}{ll}\text { Tabelas } & 100\end{array}$ 


\title{
DISTRIBUIĊ̃O DA DIVERSIDADE GENÉTICA E CORRELAÇŌES DE CARACTERES EM ETNOVARIEDADES DE MANDIOCA (Manihot esculenta, Crantz) PROVENIENTES DA A GRICULTURA TRADICIONAL DO BRASIL.
}

\author{
Autor: Roberto Cury \\ Orientador: Prof. Dr. Akihiko Ando
}

\section{RESUMO}

Os objetivos deste trabalho foram: i. avaliar a diversidade em relação a 46 descritores morfológicos, agronòmicos e químicos de 56 etnovariedades de mandioca provenientes de areas de agricultura tradicional autóctone das regiões do Rio Negro (Amazonas e Roraima), Rio Solimões (Amazonas) e litoral sul do Estado de São Paulo; ii. estimar as correlações genéticas entre os descritores, com principal ênfase nas variáveis importantes na domesticação; iii. decompor as estimativas das variâncias genéticas em relação a unidades de agrupamento: roças e regiões. iv. estudar a divergència genética das etnovariedades por meio de técnicas da análise multivariada.

A variabilidade fenotipica descrita pelos descritores morfológicos discretos foi alta. Por este paràmetro, a região do Rio Negro apresentou maior diversidade, seguida da região do Rio Solimões e por último o litoral sul do Est. de São Paulo.

A variabilidade genética demonstrada pelos descritores agronòmicos, quimicos do caule e químicos da raiz também foi alta. Já a variabilidade genética descrita pelos descritores quimicos das folhas não foi tão expressiva. Os descritores continuos que se destacaram por apresentar alta herdabilidade no sentido amplo ao nivel de parcelas $\left(\hat{h}_{p}^{2}\right)$, alto coeficiente de variação genética $\left(\mathrm{CV}_{\mathrm{g}}\right)$ e alta razão entre o coeficiente de variação genética e o coeficiente variação ambiental $\left(\mathrm{CV}_{\mathrm{g}} / \mathrm{CV}_{\mathrm{e}}\right)$ foram: teor de cinzas no caule, teor de proteinas no caule, potencial cianogênico na entrecasca das raizes, o teor de ácido cianidrico livre na entrecasca das raizes, teor de proteina nas raizes, teor de cinzas nas raizes e teor de fibras nas raizes. 
Vários descritores apresentaram alta correlação genética. O peso de raizes apresentou correlação genética alta e positiva com os descritores peso da parte aérea $\left(r_{G 115.16)}=0.75\right)$, indice de colheita $\left(r_{G(15.17)}=0,73\right)$, número de raizes $\left(r_{G(15.18)}=0,87\right)$ e produção de amido $\left(\mathrm{r}_{\mathrm{G} 15.19)}=0,99\right)$; alta e negativa, com os descritores umidade da polpa das raizes $\left(\mathrm{r}_{\mathrm{G}_{115.391}}=-0,64\right)$ e umidade das raizes $\left(\mathrm{r}_{G(15,46)}=-0,64\right)$. O teor de amido apresentou correlação genética alta e negativa com os descritores umidade na polpa das raizes $\left(r_{G(1.1 .99)}=-0,77\right)$, teor de proteina nas raizes $\left(r_{G(41.30)}=-0,73\right)$, teor de cinzas nas raizes $\left(\mathrm{r}_{\mathrm{G}+11 .+3)}=-0.85\right)$, teor de fibras nas raizes $\left(\mathrm{r}_{\mathrm{G}(41.44)}=-0,82\right)$ e teor de umidade nas raizes $\left(r_{G+1.46)}=-0,77\right)$. Associação encontrada, principalmente entre os descritores quimicos da raiz. parece ter favorecido o processo da domesticação.

$\mathrm{Na}$ media de todos $\mathrm{o} 31$ descritores avaliados, $76,13 \%$ da variància genética total foi devida à componente entre etnovariedades dentro de roças dentro de regiões (dentro de roças), 12,81\% a componente entre regiões e $11,05 \%$ a componente entre roças dentro de regiões. A concentração da variabilidade dentro da roça (dentro da população) sugere a ocorrência de fluxo gênico entre as populações.

A região com maior diversidade genética foi a do Rio Negro, seguida da região do Rio Solimões e por último a região do litoral sul do Estado de São Paulo. O padrão de dispersão multivariado das etnovariedades no geral foi contínuo, com apenas uma etnovariedade distanciando-se em demasiado das demais. 


\section{DISTRIBUTION OF GENETIC DIVERSITY AND CORRELATION BETWEEN CHARACTERS IN CASSAVA ETHNOVARIETIES (Manihot esculenta, Crantz) DERIVED FROM TRADITIONAL AGRICULTURE OF BRAZIL}

\section{SUMMARY}

The aims of the present work were: i. to evaluate the diversity related to 46 morphological. chemical and agronomic descriptors of 56 ethnovarieties (land races) of cassava (. famihot esculenta. Crantz) which were collected from traditional agriculture of the following regions: Negro River (Amazonas and Roraima, State), Solimões River (Amazonas State) and the southern coast of Sào Paulo State; ii. to estimate genetic correlations among several descriptors with emphasis on the variables which are important for domestication; iii. to decompose the estimated genetic variance related to the unity of grouping: garden and regions; iv. to study genetic divergence of the ethnorarieties through the multivariate analysis.

The phenotipic variability shown by discrete morphologic descriptors was very high: the region of Negro River presented the highest diversity following by the regions of Solimões River and southern coast of São Paulo State.

The genetic variability demonstrated by agronomic and chemical descriptors of stem and root was also very high. On the other hand, the genetic variability shown by chemical descriptors of the leaf wasn't so expressive. The continuous descriptors distinguished by high heritability in broad sense on parcel level $\left(\hat{h}_{p}^{2}\right)$, high genetic variation coefficient $\left(\mathrm{CV}_{\mathrm{g}}\right)$ and high ratio between genetic variation coefficient and environmental variation coefficient $\left(\mathrm{CV}_{\mathrm{g}} / \mathrm{CV}_{\mathrm{e}}\right)$ were: stem ash content (dry matter), stem protein content (dry matter), cyanogenic potential of root cortex, free cyanide acid content of root cortex, root protein content (dry matter), root ash content (dry matter) and root fiber content (dry matter)

Analysis of several descriptors showed high genetic correlation Root weight presented high positive genetic correlation with the descriptors: aerial part weight 
$\left(\mathrm{r}_{\mathrm{G}(15.16)}=0,75\right)$, harvest index $\left(\mathrm{r}_{\mathrm{G}(15.17)}=0,73\right)$, number of roots $\left(\mathrm{r}_{\mathrm{G}(15.18)}=0,87\right)$ and starch production $\left(\mathrm{r}_{\mathrm{G}(15.19)}=0,99\right)$. Starch content showed high and negative genetic correlation with the descriptors: root pulp humidity content $\left(\mathrm{r}_{\mathrm{G}(41.39)}=-0,77\right)$, root protein content $\left(r_{G(+1.30)}=-0,73\right)$, root ashes content $\left(r_{G(41.43)}=-0,85\right)$, root fiber content $\left(r_{G(41.44)}=-0,82\right)$ and root (pulp and cortex) humidity content $\left(\mathrm{r}_{\mathrm{G}(41.46)}=-0,77\right)$. The correlations found between the in the chemical descriptors of roots seem to be favorable to the domestication process.

For all the 31 descriptions evaluated, on the average, $76,13 \%$ of the total genetic variance was due to components among ethnovarieties within the gardens and regions. $12.81 \%$ was due to components among regions and $11,05 \%$ among gardens within the regions. The concentration of variability within the garden (within the populations) suggests the occurrence of gene flow among the populations.

The highest genetic diversity was observed in the region of Negro River, following by the regions of Solimões River and the southern coast of São Paulo State. The multivariate pattern of the ethnovariety dispersion was, in general, continuous excepting only one ethnovariety showing more distant than the others. 


\section{INTRODUÇÃO}

O Departamento de Genética da Escola Superior de Agricultura "Luiz de Queiroz" da Lniversidade de São Paulo, vem desde a sua fundação desenvolvendo trabalhos na área de evolução de plantas cultivadas, onde no início destacaram-se trabalhos com forte abordagem multidisciplinar principalmente desenvolvidos na cultura do milho (Martins, 1996).

Como conseqüência da forte tradição na área, a partir do início da década de 90, o setor de Genética Ecológica do Departamento de Genética iniciou uma nova etapa no seu programa de pesquisa em evolução de plantas cultivadas com ênfase ao estudo do processo da domesticação de plantas com propagação vegetativa nas terras baixas sul americanas e suas conseqüências, também pautado em forte abordagem multidisciplinar.

A mandioca Manihot esculenta, Crantz foi escolhida como modelo para as espécies que apresentam propagação vegetativa, e que o objeto da domesticação envolve órgãos de reserva que desenvolvem-se no solo, como por exemplo a batata doce Ipomea batatas, o mangarito Xanthosoma sagittifolium, o cará Dioscorea trifida, o ariá Calathea allouia

A mandioca foi a escolhida por diversas razões: desde antes do descobrimento da América já era cultivada por toda as terras baixas tropicais do continente sul americano, era e ainda é a principal fonte de alimento energético cultivado para a maioria dos índios habitantes destas regiōes, e hoje é muito importante para populações que vivem da agricultura de subsistência da África e da América Latina. 
Também é muito importante para a agricultura atual como fonte de alimento energético e de amido para industria de transformação.

Além disso do ponto de vista agronômico, biológico e experimental a mandioca é uma espécie muito interessante: manteve no processo de domesticação a rusticidade; não perdeu a capacidade de se reproduzir sexualmente; é perene e pode ser mantida em coleções vivas; faz parte de um grande gênero com quase uma centena de espécies, em que muitas delas compartilham do mesmo conjunto gênico da espécie domesticada; e o mais interessante, se considerarmos o processo da domesticação como continuo, a domesticação da mandioca continua a ocorrer em muitas roças que mantêm o sistema tradicional autóctone de agricultura.

Como conseqüência do primeiro trabalho na área (Cury, 1993), alguns princípios foram estabelecidos que orientaram os trabalhos realizados a seguir e o estabelecimento de uma coleção de germoplasma: i. A população base como unidade evolutiva é delimitada pela roça cultivada, ii. O universo do conhecimento agrícola dos agricultores é muito importante e as práticas agrícolas influenciam fortemente o processo da domesticação.

Hoje o setor de Genética Ecológica do Dep. de Genética conta com uma coleção de mais de 200 etnovariedades, agrupadas por roça e localidade de coleta, sendo que para maioria da coleção as informações etnobiológicas foram preservadas. Além disso é a única coleção a apresentar materiais do baixo Rio Negro (AM), rio Branco (RR) e baixo Rio Solimões (AM) (Fukuda, et alii 1996). A região do Rio Negro é muito importante pois apresenta alta concentração de tribos indigenas cuja ênfase na agricultura sempre foi o cultivo da mandioca (Ribeiro, 1995).

Portanto os objetivos deste trabalho inserem-se no programa de pesquisa de domesticação da mandioca do referido setor, e dois trabalhos complementares com abordagens de genética molecular e genética isoenzimática estão sendo desenvolvidos paralelamente e complementarmente com o mesmo conjunto de etnovariedades.

Mais especificamente os objetivos deste trabalho foram: 
- Avaliar a diversidade em relação 46 descritores morfológicos, agronômicos e químicos de 56 etnovariedades de mandioca provenientes de áreas de agricultura tradicional autóctone das regiões do Rio Negro (Amazonas e Roraima), Rio Solimões (Amazonas) e litoral sul do Estado de São Paulo.

- Estimar as correlações genéticas entre os descritores, com principal ênfase nas variáveis importantes na domesticação.

- Decompor as estimativas das variâncias genéticas em relação a unidades de agrupamento: roças e regiões.

- Estudar a divergência das etnovariedades por meio técnicas da análise multivariada. 


\section{REVISÃO DE LITERATURA}

\subsection{A Mandioca}

\subsubsection{O gênero Manihot, Mill.}

Manihot esculenta Crantz pertence a classe Dicotyledoneae, subclasse Archilamydeae, ordem Euphorbiales, tribo Manihoteae e gênero Manihot.

Atualmente o trabalho de Rogers \& Appan (1973) é a referência taxonòmica para o gênero, mas não é um consenso. Allem (1989a) reduziu a seção Quinquelobae de 14 para 10 espécies, e o mesmo autor em outro trabalho (Allem, 1989b), descreveu quatro novas espécies de Manihot endêmicas de micro-regiões brasileiras. Alguns fatos colaboraram para a indefinição taxonômica do gênero: o primeiro é o pouco conhecimento das espécies de Manihot sul-americanas; o segundo refere-se ao pouco conhecimento da especiação, pois as espécies botânicas são variáveis quanto a estrutura vegetativa, mas são relativamente uniformes quanto aos órgãos florais, o que propicia a formulação de hipóteses a respeito da recente origem do gênero.

O gênero Manihot é nativo do continente americano, estendendo-se do extremo sul dos EUA ao norte da Argentina. Rogers (1963) e Rogers \& Appan (1973) reconhecem dois grandes centros de diversidade de espécies: o primeiro abrangendo das áreas secas do oeste mexicano à Guatemala e o segundo as regiões nordeste, centro-oeste e sudeste brasileiras. Nassar (1978c) subdividiu o grande centro brasileiro em três, reconhecendo quatro centros de diversidade de espécies: sul de Goiás a oeste de Minas 
Gerais com 38 espécies, sudoeste do México com 19 espécies, nordeste do Brasil com 18 espécies e o oeste do Mato Grosso do Sul e extremo leste da Bolivia com 6 espécies.

Os grupos formados pelas espécies das Américas do Norte e Central e as da America do Sul são marcadamente distintos; com exceção de $M$. esculenta nenhuma das especies da América do Norte se encontra na América do Sul e somente uma espécie da América do Sul, 1. brachylola, é encontrada na América Central.

Todas as especies do gênero são sensiveis a baixas temperaturas, não sendo encontradas em altitudes superiores a 2.000 metros; somente se conhecem duas espécies tolerantes às geadas: M. grahami e M. anisophylla.

Vo geral, as especies de Manihot são encontradas nas diversas unidades fitogeográficas tropicais, mas são mais abundantes em ecossistemas secos. São esporadicas em sua distribuição e nunca são membros dominantes na vegetação. Em ecossistemas florestais, são encontradas em clareiras naturais ou artificiais, sendo consideradas espécies heliófilas e invasoras (Rogers \& Appan, 1973).

Todas as espécies são perenes e variam seu tipo de crescimento, desde arbustos aparentemente desprovidos de caules até árvores com diâmetro de tronco de 30 $\mathrm{cm}$ e altura de 10 a $12 \mathrm{~m}$.

$\mathrm{O}$ gènero apresenta espécies com duas caracteristicas econômicas importantes: presença de raizes tuberosas com acúmulo de amido, cujos expoentes são M. esculenta e M. tristis, e produção de látex cujo expoente é $M$. glaziovii.

\subsubsection{Citogenética}

O primeiro trabalho sobre citologia de Manihot esculenta data de 1935 , "Contribuição para o estudo cytológico da mandioca" de E. A. Graner. Neste clássico trabalho, Graner (1935) observou mais de duzentas metáfases somáticas de 37 variedades de mandioca, onde constatou 36 cromossomos, medindo 1 a 2 micra de comprimento por 
aproximadamente 0.3 micra de largura. o autor observou ainda metáfases da primeira divisão meiótica com 18 cromossomos duplos.

Apesar do pioneirismo do trabalho de Graner, há mais de 50 anos atrás, muito pouco se conhece a respeito da citogenética do gènero Manihot. Das quase uma centena de especies. apenas 20 tiveram o número de cromossomos determinado e em todas foi constatada a ocorrència de 36 cromossomos (Perry, 1943; Cruz, 1968; Nassar 1978a e Silva Jardim, 1984)

Quanto ao nivel de ploidia, Perry (1943) sugere o número básico $x=9$ para o gènero Manihot. Reforçando a hipótese de tetraploidia, Magoon et al. (1969) e Lmanah \& Hartman (1973) observaram a presença de dois pares de cromossomos satélites em M. esculenta e M. glaziovii.

Se os trabalhos de determinação do número cromossômico no gènero Manihot são raros, mais raros ainda são aqueles com respeito a morfologia cromossômica. L'manah \& Hartman (1973) compararam a morfologia cromossômica de M. esculenta e M. glaziovii através das seguintes características: comprimento total, comprimento relativo de braços, posição do centrômero e número de cromossomos satelites. Com exceção do segundo par de cromossomos-sat que em M. glaziovii apresentou comprimento total médio de 3,1 micra e em $M$. esculenta 2,2 micra, os cariotipos foram considerados similares.

Bai et al. (1992) avaliaram o pareamento dos cromossomos no paquiteno da meiose e a separação dos cromossomas na anáfase I dos seguintes híbridos interespecificos: (1) M. esculenta $\times$ M. glaziovii, (2) M. esculenta $\times$ M. epruinosa, (3) M. esculenta $\times$ M. leptophylla, (4) M. esculenta $\times$ M. brachvandra, (5) $M$ esculenta $\times M$. gracilis, (6) M. esculenta M. anomala, (7) M esculenta $\times$ M. tristis, (8) M esculenta $\times$. pohlii, (9) M esculenta $\times$ M. tripartita e (10) M esculenta $\times$ M. flabelifolia. Todos os cruzamentos apresentaram pareamento normal, com exceção do cruzamento (5) que em algumas células foram observados a formação de 17 bivalentes e dois monovalentes. Foi observado ainda a separação normal na anáfase 1 para todos os cruzamentos os 
cruzamentos, e apenas nos hibridos (2), (5) e (10) foram constatados algumas meioses anormais.

\subsubsection{Genética}

A mandioca apresenta várias caracteristicas que favorecem a exogamia: monoicia com dicogamia protoginica, macho esterelidade e a visitação a flores por insetos (Hershey \& Amaya, 1984b). Mas as caracteristicas acima não são suficientes para descartar a autogamia, pois ela pode ocorrer com a abertura sincrònica de flores masculinas e femininas de diferentes cachos da mesma planta ou de diferentes cachos de individuos clonados.

Desta maneira, tanto a autofecundação quanto o cruzamento podem ocorrer naturalmente, sendo que a taxa de cruzamento é dependente da composição da população, mais especificamente de fatores como número de individuos geneticamente diferentes, porcentagem de cultivares macho estéreis, sincronia do florescimento dos cultivares e disposição dos diferentes cultivares no campo.

Devido ao comportamento genético da mandioca, alta heterozigosidade e forte depressão quando submetida a endogamia, pode-se considerá-la como preferencialmente exogâmica. Kawano et al. (1978) demonstraram este fato através de autofecundação de 192 progênies, onde obtiveram perda de vigor média de $54 \%$ para o caráter produção de raizes.

Com respeito a herança dos diversos caracteres, pouco se conhece se compararmos a mandioca a outras espécies de importância alimentar.

Graner (1942) estudou a herança de dois caracteres largura dos lobos das folhas e coloração da pelicula suberosa da raiz, concluindo que ambos apresentam segregação simples segundo a primeira lei de Mendel e são independentes entre si, sendo que lobo estreito das folhas (tipo vassourinha) é dominante sobre lobo largo e pelicula 
marrom da raiz é dominante sobre película branca. Segundo Hershey \& Amaya (1984b), a coloração das nervuras das folhas, verde ou roxa, é também utilizada como marcador.

Outros caracteres com herança monogènica conhecida são: produção de clorofila sendo normal (A) dominante sobre albino (a); hábito de crescimento do talo, sendo crescimento reto $(Z)$ dominante sobre crescimento em ziguezague $(z)$; cor do colènquima do caule. sendo verde claro $(G)$ dominante sobre verde escuro $(\mathrm{g})$; cor do parènquima (polpa) da raiz, herança codominante, branco (yy), amarelo (YY) e amarelo claro (Yy): (Hershey \& Ocampo, 1989). A forma da folha normal (P) versus folha pandurada ( $p$ ) não apresentou herança simples, sendo influenciado por genes não alelos.

A maioria dos caracteres de importância agronômica é controlada por sistemas poligènicos. Kawano (1984), resumindo experimentos realizados pelo CIAT, comenta que os caracteres índice de colheita, conteúdo de matéria seca na raiz e grau de podridão de raizes apresentam alta correlação entre clones genitores e filhos. As resistèncias a bacteriose e a cercospora também são transmitidas facilmente as progènies incluindo as obtidas por hibridação. Já a produção de raizes apresenta baixa correlação entre pais e filhos.

Acosta Espinoza (1984), estudando os progenitores Vassourinha, Branca de Santa Catarina, IAC 12-829, IAC 105-66, IAC 14-18, Taquari, Aipim Bravo, Mico e Engana Ladrão e suas respectivas progènies policruzadas, obteve, respectivamente, as seguintes estimativas para o coeficiente de determinação genotípica, herdabilidade no sentido restrito para progènies policruzadas e coeficiente de variação genética: 0,203, 0,118 e $10,3 \%$ para produção de raizes; $0,374,0,300$ e $18,5 \%$ para peso da parte aérea; $0.376,0.580$ e $7.6 \%$ para índice de colheita; e $0,183,0,231$ e 5,5\% para número de raizes

Barriga (1980) avaliou 12 cultivares de mandioca, sendo 6 de origem amazònica, 2 do nordeste e 4 da região centro sul, em très localidades: Belém - PA, Tracuateua- PA e Macapá- AP, durante três ciclos. Para a variável produção de raízes, as interaçoes simples cultivares $\mathrm{x}$ locais e cultivares $\mathrm{x}$ anos foram significativas, e também foi significativa a interação tripla cultivares $\mathrm{x}$ locais $\mathrm{x}$ anos. Já com relação a variável 
produção de rama, a interação foi significativa para clones $x$ locais, mas não foi significativa para clones $\mathrm{x}$ anos. As estimativas do coeficiente de determinação genotipica. para o variável produção de raízes variaram de 0,610 a 0,941 e para o coeficiente de variação genética, variaram de $22 \%$ a $44 \%$ de acordo com o ano e ou locais avaliados.

Avaliando 146 cultivares do banco de germoplasma da Embrapa de Cruz das Almas. Dantas (1984) estimou os seguintes valores para o coeficiente de determinação genotipica ao nivel de médias: $87,14 \%$ para produção de raizes, $89,10 \%$ para produção de hastes e ramas, $86,62 \%$ para produção de ramas, $85,53 \%$ para produção total. $90.25 \%$ para indice de colheita e $92,80 \%$ para teor de amido determinado pelo metodo da balança hidrostática.

\subsubsection{Domesticação}

As especies de plantas que foram domesticadas nas terras baixas americanas podem ser agrupadas em dois grupos: i. espécies de frutas, ii. plantas alimenticias (Martins, 1994).

A mandioca está dentro do grupo de espécies alimentícias que foram domesticadas nas terras baixas sul americanas. Este grupo de espécies apresenta caracteristicas em comum: a parte comestivel são tubérculos e são propagadas vegetativamente para cultivo. A única exceção é o amendoim, entretanto também neste caso a parte comestivel desenvolve-se dentro da terra (Martins, 1994).

Apesar da importància da mandioca para as populações pré-colombianas das terras baixas americanas, constituindo-se para a maioria das populações indígenas como a principal fonte de alimentos energéticos, poucas informações arqueológicas e geográficas a respeito da cultura estão disponiveis. 
Lathrap (1973) e Reichel-Dolmantoff (1965) sugerem que os ancestrais da mandioca estiveram entre as plantas utilizadas como alimento pelos indios americanos e que há evidências de que a farinha de mandioca foi importante no comércio do nordeste da América do Sul entre o segundo e o terceiro milênio antes de Cristo. Rouse \& Cruxent (1963) dataram artefatos para processar mandioca entre 3000 e 7000 anos atrás. McQuown. citado por Hershey \& Amaya (1984a), indica que a palavra maia para designar mandioca está em uso há cerca de 3500 anos.

Do ponto de vista da taxonomia clássica, a questão da domesticação da mandioca é controversa.

Rogers \& Appan (1973) consideram que Manihot esculenta Crantz é apenas encontrada na forma domesticada e que as espécies selvagens mais aparentadas e provaveis ancestrais do cultigeno são $M$. aescutifolia, $M$. pringlei e $M$. rubricaulis, todas nativas da América Central e México.

Allem ${ }^{1}$ considera que o cultígeno e uma gama de populações selvagens aparentadas são a mesma espécie botânica, e para tanto considera três subespécies: $M$. esculenta subesp. esculenta, que compreende todas as formas cultivadas; $M$. esculenta subesp. peruviana, que compreende as antigas espécies M. peruviana e M. surumuensis, nativas do leste do Peru e oeste do Brasil; M. esculenta subespécie flabelifolia que compreende as antigas espécies $M$. digitiformis, M. melanobasis, M. tristis, $M$. marajoara, M. sprucei, M. saxicola, M. orinocensis e M. surinamensis; nativas das áreas de transição para floresta amazònica do Mato Grosso, Goiás, Pará e Venezuela.

Trabalhos com base em informação molecular reforçam a tese de que o cultigeno é mais próximo das espécies da América do Sul.

Schaal et al. (1994) comparou M. esculenta com 6 espécies selvagens da América do Sul e 10 espécies selvagens da América do Norte, entre estas M. pringlei, M. rubricaulis e M. aescutifolia, com base em dados das seqüências ITS do DNA ribossòmico nuclear, e concluiu que $M$. esculenta e as espécies da América do Sul formam um conjunto isolado das espécies da América do Norte. 
A respeito do isolamento reprodutivo do cultigeno, os dados da literatura são escassos mas apontam no sentido de que o mesmo e as espécies selvagens de Manihot compartilham do mesmo conjunto gênico, mas em diferentes graus.

Storey \& Nichols (1938) utilizaram M. glaziovii em retrocruzamentos com M. esculenta, no melhoramento da mandioca na África, com objetivo de transferir a resistència ao mosaico comum.

Jennings $(1959,1963)$ relatou cruzamentos entre variedades do cultigeno e as espécies $M$. glaziovii, $M$. dichotoma, M. melanobasis e uma espécie não identificada denominada Tree Cassava. Com exceção dos hibridos entre $M$. esculenta e $M$. melanobasis, a fertilidade caia bruscamente na geração $F_{1}$, sendo recuperada após dois ou très retrocruzamentos para $M$. esculenta. Ao contrário, o $F_{1}$ entre $M$. esculenta e $M$. melanobasis não mostrou decréscimo na fertilidade.

Nassar (1978b) cruzou M. esculenta com M. anomala, M. olighanta, M. gracillis e $M$. zehntneri, sendo que todos os cruzamentos mostravam-se férteis, com pareamento normal dos cromossomos. Nassar (1979) relatou que sementes de híbridos entre $M$. esculenta e as espécies $M$. oligantha, $M$. tripartita, $M$. anomala e $M$. reptans apresentaram germinação de 12, 5, 4 e 9\%, respectivamente.

Já Silva Jardim (1984) não obteve sucesso no cruzamento dos cultivares Cateto, Vassourinha e Branca de Santa Catarina com as espécies M. glaziovii, M. pseudoglaziovii, M. caerulescens e M. pohlii.

Bai et al. (1992) avaliaram o pegamento e a formação de sementes dos cruzamento do cultígeno com as espécies $M$. anomala, M. epruinosa, M. tristis, $M$. gracillis, M. tripartita, M. leptophylla e M. pol hlli. A porcentagem de frutos formados e sementes formadas para os cruzamentos interespecíficos foram, respectivamente de: 17,40 e $16,12,16,14$ e $17,07,23,26$ e $17,38,21,50$ e $17,92,26,00$ e $21,33,1,94$ e 1,44 , e 9,32 e 8,28 .

Do ponto de vista da alteração dos caracteres na domesticação, Jennings (1979) afirma que a domesticação da mandioca envolveu seleção para tamanho do

\footnotetext{
Allem. C.A. The origin of Manihot esculenta, Crantz (Euphorbiaceae).
} 
tubérculo. hábito de crescimento ereto, menor número de ramificações, e habilidade para propagação vegetativa através de pedaços do caule (maniva). O processo gerou respostas correlacionadas em diversos outros caracteres, como, por exemplo: a seleção para plantas menos ramificadas favoreceu genótipos menos floriferos e a seleção para propagação vegetativa favoreceu genótipos com acúmulo de reserva no caule e gemas caulinares protuberantes.

A dinàmica evolutiva da mandioca tem sido estudada mais recentemente no Setor de Genética Ecológica do Departamento de Genética da ESALQ-USP, sendo que a mandioca foi adotada como espécie modelo no estudo da domesticação de plantas tuberosas, propagadas vegetativamente para cultivo e que foram domesticadas nas terras baixas da America do Sul. Nestes estudos, algumas questões básicas são investigadas: Como as populações tradicionais ou autóctones mantém alta diversidade intraespecífica? Em plantas. cuja propagação para cultivo é vegetativa, quais fatores são responsáveis pela geração e seleção da variabilidade? (Cury, 1993; Martins, 1994).

$\mathrm{Na}$ agricultura autóctone ou tradicional, a população referencial na qual atuam os processos evolutivos é população da espécie cultivada na roça. Assim sendo, numa população de mandioca na roça autóctone, supõe-se a atuação dos seguintes fatores evolutivos: recombinação, hibridação interespecífica, migração e mutação (Cury, 1993)

Na mandioca, a recombinação é sem dúvida o principal amplificador da variabilidade genotipica da população e se dá preferencialmente pela hibridação intraespecifica já que a mandioca apresenta diversas barreiras contra a autofecundação². Nas nossas coletas é comum a identificação de recombinantes, alguns agricultores a denominam mandioca de semente (Martins, 1994), outros de mandioca do céu³

A importància da recombinação como amplificadora da variabilidade genotípica foi demonstrada por Peroni (1998). Estudando 7 roças de mandioca em áreas de Mata Atlàntica do sul do Estado de São Paulo o autor encontrou, através de

\footnotetext{
- Como as etnovariedades de Manihot esculenta na maioria dos casos são altamente heterozigotas. a autofecundação pode teoricamente amplificar a variabilidade genotípica.
} 
amostragem aleatória na população da roça, números de genótipo de 1,8 a 6 vezes superior ao número de etnovariedades reconhecido pelo agricultor.

A migração possibilita a ocorrência de fluxo gênico entre diferentes roças, sendo principalmente consequeencia da ação humana através da introdução ou troca de cultivares. já que a dispersão de gametas e sementes parece ser limitada na mandioca. Em algumas regiōes. o papel da migração é grande e relacionado a caracteristicas étnicas e culturais de populações humanas (Chernela, 1987). A migração amplifica a variabilidade genética e genotipica da população (Cury, 1993).

Informações de agricultores caiçaras coletadas por Martins (1994) sugerem a formação de banco de sementes de mandioca por ate 25 anos. No entanto, Almeida (1987) não conseguiu comprovar a presença de banco de sementes em roças de agricultura tradicional do Litoral Norte do Estado de São Paulo. Se confirmado, a formação de banco de sementes em roças tradicionais (autóctones) significa a possibilidade de ocorrència de fluxo gênico no tempo.

A hibridação interespecífica entre o cultígeno $\mathrm{e}$ as selvagens, via hibridação introgressiva, é uma possibilidade concreta no gênero Manihot, Mill proporcionada, pela simpatria de ambas na agricultura autóctone e pelo compartilhamento do mesmo conjunto gênico (Cury, 1993). Martins (1994) encontrou muitas mandiocas selvagens dentro das roças nas localidades Marará e Panacarica, ao longo do Rio Branco no Estado de Roraima.

O papel da mutação é clássico, e seu efeito é aumentar o número de alelos por loco (Stebbins, 1970). No caso da mandioca, as mutações podem ser fixadas via propagação vegetativa (Cury, 1993).

Na população da roça atuam a seleção natural e a seleção artificial. A seleção natural no ambiente da agricultura tradicional autóctone é muito forte devido a rusticidade do ambiente agricola. A seleção artificial é fundamental para que os novos recombinantes sejam incorporados ao conjunto de etnovariedades (Cury, 1993; Martins, 1994)

\footnotetext{
${ }^{3}$ Eng Agr. Fábio de Oliveira Freitas. comunicação pessoal.
} 


\subsection{Composição química da mandioca}

\subsubsection{Composição das raízes da mandioca.}

Os principais componentes das raizes são água, os carboidratos, as proteinas, o extrato etéreo, as fibras e as cinzas. As frações normalmente são expressas em porcentagens da matéria úmida ou da matéria seca.

A água sempre representa maior porção das raizes sendo normalmente superior a $60 \%$ do peso das raizes.

A segunda fração mais importante é a de carboidratos que chega a representar cerca de $90 \%$ da matéria seca. Os carboidratos são constituidos na sua maior parte por amido e também por uma pequena fração de açucares redutores (glicose, frutose e maltose) e não redutores (sacarose e rafinose).

A fração protéica é baixa na raiz e além disso não é de boa qualidade. Apresenta baixos teores de histidina, prolina e glicina, e é deficiente nos amino ácidos que contém enxofre, como a metionina, a cisteina, treonina, isoleucina e triptofano.

A fração lipidica geralmente representa no máximo $1 \%$ da matéria seca, é composta por $39 \%$ de ácido oléico, $35 \%$ de palmítico, $18 \%$ de linoléico, $5,6 \%$ de linolênico e 3,1\% de esteárico.

A fração das fibras também é baixa e dificilmente ultrapassa $2 \%$ da matéria seca, apesar do aspecto fibroso das raizes. Segundo Cereda (1994), a metodologia tradicional de análise subestima o teor de fibras.

A fração cinzas representa os minerais, normalmente não ultrapassa $4 \%$ da matéria seca, é composta principalmente de nitrogênio, fósforo, potássio, cálcio, magnésio e sódio, e normalmente apresenta baixos teores de ferro (Cereda, 1994).

Na literatura, é ampla a variação apresentada dos teores da composição centesimal das raizes da mandioca. Cereda (1994) chama atenção para variação devido a 
metodologia da análise. Pode - se citar ainda a variação devido a idade das raizes, ao tipo ou ao formato das raizes, a variabilidade genética entre as cultivares e variação devido aos efeitos ambientais.

Conceição (1987) apresentou a seguinte faixa de variação para composição quimica das raizes de mandioca: umidade de 60 a $65 \%$, amido de 21 a 33\%, proteina de 1,0 a $1,5 \%$, gordura de 0,18 a $0,24 \%$, fibras de 0,70 a $1,06 \%$ e cinzas de 0,60 a $0.90 \%$.

Cereda (1994) a partir de dados de Marttelli (1951) demonstrou que há variação nos componentes da análise centesimal em raizes de diferentes tamanhos. Para raizes. longas e finas, e curtas e grossas, apresenta respectivamente os seguintes teores: 62,10 e $62,10 \%$ para umidade, 1,60 e 1,14 para fibras, 0,65 e 0,24 para extrato etéreo, 0,32 e 0,11 para nitrogênio, 32,95 e 34,70 para carboidratos e 1,20 e 0,86 para cinzas.

Lorenzi (1978), analisando os teores de matéria seca, amido, carboidratos solúveis totais e açúcares redutores das raizes, da variedade IAC-mantiqueira, aos 0, 3, 7, 10 e 14 dias após a poda, encontrou diferenças significativas para os teores de amido e carboidratos solúveis totais, com redução no teor de amido e aumento do teor de carboidratos solúveis totais.

Albuquerque \& Cardoso (1980) apresentaram a variação do teor de água e do teor de amido, para 26 cultivares aos 18 meses de idade procedentes da zona do Tocantins. O teor de água apresentou média de $68,15 \%$, mínimo de $53,38 \%$ e máximo de $92,14 \%$. O teor de amido na base seca apresentou média de $65,50 \%$, mínimo de $35,93 \%$ e máximo de $78,13 \%$.

Wheatley et al. (1992) fizeram a avaliação dos teores de matéria seca e amilose, da "core collection" do CIAT envolvendo 630 clones de mandioca. O teor de matéria seca apresentou média de $34,2 \%$, mínimo de $13 \%$ e máximo de $48,9 \%$. O teor de amilose, em porcentagem da fração amido, apresentou média de $22,3 \%$, mínimo de $15,3 \%$ e máximo de $28,8 \%$. 


\subsubsection{Composição das folhas da mandioca}

Cereda (1994), a partir de dados de Martelli (1951), apresentou a seguinte composição centesimal para folhas da mandioca: água 77,20 \%, fibra 2,54\% da matéria úmida (m.u.), extrato etéreo $1,31 \%$ da m.u., nitrogênio $1,10 \%$ da m.u., carboidrato $10,33 \%$ da m.u e cinzas $1,77 \%$ da m.u..

West et al. (1988) citado por Bokanga (1994b), apresentaram a seguinte composição das folhas de mandioca: $72,0 \%$ de umidade, $7,0 \%$ de proteína bruta, 1,0\% de gordura. $14.0 \%$ de carboidrato total, $4,0 \%$ de fibra bruta e $2,0 \%$ de cinza.

Bokanga (1994b), citou a avaliação de 151 genótipos de mandioca, ainda não publicada. onde foram encontrados média de $26 \%$, mínimo de $20 \%$ e máximo de $32 \%$ para o teor de proteínas nas folhas, na base seca. Albuquerque \& Cardoso (1980) encontraram a amplitude de $8,28 \%$ a $13,64 \%$ para o teor de proteína bruta das folhas úmidas, de 33 clones de mandioca.

No Brasil, as folhas da mandioca são pouco utilizadas na alimentação humana, como por exemplo, no preparo no prato da maniçoba, comida tipicamente amazònica que envolve o preparo das folhas com produtos de origem animal.

Atualmente, devido a importância das folhas na dieta dos habitantes de alguns países africanos, a pesquisa sobre a composição química das folhas da mandioca tèm apresentado interesse crescente. Na África, em países como Zaire, Congo, Tanzânia, Serra Leoa e Guiné, as folhas da mandioca constituem hoje o maior componente da dieta. Conforme Bokanga (1994b), as folhas jovens e tenras são selecionadas, amassadas e fervidas por 15 a 30 minutos, e vários ingredientes são então adicionados para o sabor. Lancaster \& Brooks (1983) citado por Bokanga (1994b), afirmam que no Zaire o consumo diário por habitante de folhas de mandioca é de $500 \mathrm{~g}$. 


\subsubsection{Composição do caule da mandioca}

Sobre a composição química do caule, há poucas referências. Cereda (1996) apresentou a seguinte composição: umidade 65\%, proteina 6,25\% da matéria seca (m.s.), carboidrato $31,91 \%$ (m.s.), matéria graxa $1,78 \%$ (m.s.), cinzas 6,15\% (m.s.) e fibras $52.55 \%$ (m.s.)

\subsection{4. $\mathrm{O}$ ácido cianídrico na mandioca.}

$\mathrm{O}$ cianeto ( $\mathrm{CN}-)$ é encontrado na mandioca na forma livre ou como radical de glicosidios. A forma livre é encontrada geralmente em pequenas quantidades que não ultrapassam $15 \%$ do teor total.

Os glicosídios cianogênicos da mandioca são a linamarina e a lotaustralina. A linamarina está presente em maior quantidade. Os glicosídios cianogênicos são estáveis dentro dos tecidos da mandioca e requerem para a hidrólise e conseqüente liberação de ácido cianidrico a presença de enzimas hidrolíticas, a linamarinase. Conforme Cereda (1994), a linamarinase tem pH ótimo entre 5,5 a 6,0, sendo fortemente inibida por gluconoladona.

A sintese dos glicosídios cianogênicos na mandioca se dá principalmente nas folhas, e nas raizes pouca sintese parece ocorrer (Selmar, 1994). Como em todos os órgãos da planta são encontrados os glicosídios cianogênicos, inclusive nas raizes que funcionam como órgão de armazenamento, o autor propõe a existência de um sistema de translocação, que evite o contato dos glicosídios com as enzimas hidrolíticas. Nas células os glicosidios são armazenados no vacúolo e as enzimas hidrolíticas localizam-se na parede celular. O sistema proposto por ele, para evitar a hidrólise dos glicosídios no trajeto, seria que o monoglicosídio linamarina é transformado no diglucosídio linustatina, antes do transporte via floema até as raizes. 
O radical livre $(\mathrm{CN}-)$ é tóxico aos animais superiores, as plantas e aos microorganismos. Nas plantas superiores e nos microorganismos, o cianeto interfere na fosforilação oxidativa, combinando-se com o citocromo oxidase, inibindo o transporte eletrònico. e consequientemente a formação de ATP (Cereda, 1994). Nos animais superiores a ação tóxica explica-se pela afinidade do cianeto com o ferro, formando ciano-hemoglobina.

A primeira classificação da mandioca de acordo com sua toxidade foi proposta por Kock (1933). Ele classificou as variedades em: i. Inócuas - até $50 \mathrm{mg} / \mathrm{kg}$ de $\mathrm{HCN}$ na polpa crua: ii. Moderadamente venenosas - de 50 a $100 \mathrm{mg} / \mathrm{kg}$ na polpa crua; iii. Venenosas - mais de $100 \mathrm{mg} / \mathrm{kg}$ na polpa crua. Já Normanha (1956) propõe o limite $0.01 \%$ ou $100 \mathrm{mg} / \mathrm{kg}$ na polpa fresca como índice de segurança para julgar a não toxidez para consumo de raizes cozidas

A concentração de ácido cianídrico livre e total varia muito, componentes geneticos e ambientais estão envolvidos e ainda acorrem variações entre órgãos de uma mesma planta. entre tecidos de um mesmo órgão e entre tecidos em diferentes idades. Por isso e ainda devido a diferenças de metodologia de análise e de amostragem, é muito dificil comparar dados de diferentes trabalhos sobre determinação do teor de ácido cianidrico na mandioca

A distribuição do potencial cianogênico no germoplasma da mandioca foi estuda por Bokanga (1994a). Analisando dados de 881 genótipos do IITA, 559 acessos da "core collection" do CIAT, 184 genótipos do Cameroun e 144 cultivares locais da Nigeria. o autor concluiu que a maioria dos genótipos de mandioca apresenta baixo potencial cianogênico na polpa da raiz.

No geral, o potencial cianogènico é superior nas folhas se comparado às raizes. Nas raizes, é superior no córtex (entrecasca) se comparado à polpa (parènquima). A correlação entre o potencial cianogênico nas folhas e na raiz é baixa. Conforme Bokanga (1994a), as razões para a baixa correlação seriam a presença de dois controles, o primeiro a saida dos glicosidios das células das folhas para o floema, e o segundo seria a transferência do floema para o parênquima da raiz. 
Numa nota muito interessante para a época, Normanha (1956) relatou que na parte aerea as folhas são mais ricas em $\mathrm{HCN}$, e nas raizes o córtex é muito mais rico do que a polpa. E ainda supòs que, a não retirada do córtex pode ser uma das explicações para a intoxicação causada pela ingestão de raizes cozidas.

Bokanga (1994b) afirmou que o potencial cianogènico das folhas é cerca de 5 a 20 vezes superior ao potencial das partes comestiveis das raizes. No entanto, a possibilidade de intoxicação humana através das folhas é rara, devido ao processamento para consumo.

Ainda conforme Bokanga (1994b), as folhas além de apresentarem altos niveis de glicosidios cianogènicos, apresentam também grandes quantidades da enzima linamarinase. No processamento quando as folhas são amassadas e os tecidos conseqüentemente rompidos, a enzima entra em contato com os glicosidios que são rapidamente quebrados a cianohidrinas. Próximo do $\mathrm{pH}$ neutro, ocorre a aceleração da quebra das cianohidrinas e conseqüente liberação do $\mathrm{HCN}$. Na temperatura ambiente, o $\mathrm{HCN}$ é um gás. com ponto de ebulição de $25,7^{\circ} \mathrm{C}$. A fervura das folhas aumenta a velocidade de remoção do ácido cianídrico devido a rápida evaporação.

Sinha \& Nair (1968) analisaram o teor de HCN na polpa e na casca da raiz de uma mesma variedade de mandioca cultivada em 5 localidades diferentes. $\mathrm{Na}$ polpa. encontrou amplitude de variação de 30,2 a $102,0 \mathrm{mg} / \mathrm{kg}$ e na casca de 432 a 560 $\mathrm{mg} / \mathrm{kg}$. Bokanga et al. (1994) avaliaram o potencial cianogènico de um genótipo de mandioca. em 8 locais e em dois anos. Para o primeiro ano de avaliação 1990/91, encontrou média de $50,9 \mathrm{mg} / \mathrm{Kg}$, e variação de 15,7 a $80,4 \mathrm{mg} / \mathrm{kg}$, para os diferentes locais. Para o segundo ano de avaliação 1991/92, encontrou média de 93,00 mg/kg e variação de 50,2 a $175,4 \mathrm{mg} / \mathrm{kg}$, para os diferentes locais.

Sinha \& Nair (1968) analisaram também o teor de HCN na polpa e na entrecasca da raiz de 33 diferentes variedades de mandioca. Das 33 variedades analisadas, 31 apresentaram o teor de $\mathrm{HCN}$ da entrecasca superior ao da polpa, em 1 variedade os teores foram praticamente iguais e em apenas 1 o teor da entrecasca foi inferior ao da polpa. O teor de HCN na entrecasca apresentou média de $465,5 \mathrm{mg} / \mathrm{kg}$, mínimo de 151,0 
$\mathrm{mg} / \mathrm{kg}$ e maximo de $1076,0 \mathrm{mg} / \mathrm{kg}$. O teor de $\mathrm{HCN}$ na poupa apresentou média de 150,0 $\mathrm{mg} / \mathrm{kg}$, minimo de $24.0 \mathrm{mg} / \mathrm{kg}$ e máximo de $490,0 \mathrm{mg} / \mathrm{kg}$.

Analisando as raizes de 13 variedades de mandioca dos índios Tukâno, Dufour (1988) encontrou média de $1.088,0 \mathrm{mg} / \mathrm{kg}$, mínimo de $733,3 \mathrm{mg} / \mathrm{kg}$ e máximo de 1.343.2 $\mathrm{mg} / \mathrm{Kg}$, para o potencial cianogênico, e média de $68,3 \mathrm{mg} / \mathrm{kg}$, mínimo de 42,0 $\mathrm{mg} / \mathrm{kg}$ e máximo de $110,4 \mathrm{mg} / \mathrm{kg}$, para o teor de HCN livre.

A herança do potencial cianogênico é complexa. Uma série de experimentos conduzidos pelo IITA estimou a herdabilidade no sentido amplo do caráter potencial cianogènico na raiz avaliado através do método enzimático (Dixon, et al., 1994). As herdabilidades estimadas nos diferentes experimentos foram: i: 0,00 (ensaio com 25 clones); ii: 0,13 (ensaio com 15 clones); iii: 0,28 (ensaio com 10 clones); iv: 0,35 (ensaio com 10 clones); v: 0,50 (ensaio com 10 clones). 


\section{MATERIAL E MÉTODOS}

\subsection{Material}

O material genético utilizado no presente trabalho foi composto de 56 variedades de mandioca, sendo 30 etnovariedades da bacia do Rio Negro nos Estados do Amazonas e Roraima. 16 etnovariedades da bacia do Rio Solimões no Estado do Amazonas, 9 variedades do litoral sul do Estado de São Paulo e 1 variedade comercial adotada como referència.

A coleção da bacia Amazônica e do litoral sul do Estado de São Paulo foram formadas pelo Setor de Genética Ecológica do Departamento de Genética da ESALQ-USP. A coleção da Amazônia encontra-se sucintamente descritas em Martins (1994). A variedade referència adotada foi a IAC Mantiqueira. Todas as variedades fazem parte da coleção do Departamento de Genética da ESALQ-USP.

Maiores detalhes sobre a agricultura do litoral sul do Estado de São podem ser encontradas em Cury (1993). Sobre a etnografia e agricultura da bacia do Rio Negro em Ribeiro (1995).

No estabelecimento da coleção cada variedade foi considerada como clone e as estacas foram colhidas de uma ou no máximo duas plantas. Como relacionado na Tabela 1 foram preservadas as informações de agrupamento, roça e localidade de plantio, e caracteristicas gerais como uso e origem. Devido ao fato de que as variedades no momento da coleta estavam sendo cultivadas num contexto étnico, as denominamos de etnovariedades. 


\subsection{Ensaio de campo}

O experimento foi instalado na Estação Experimental de Anhembi, pertencente ao Departamento de Genética da ESALQ-USP, no inicio de novembro de 1994. e o delineamento experimental utilizado foi blocos ao acaso com 3 repetições, 56 tratamentos e parcela constituída de 5 plantas.

A referida estação localiza-se no Municipio de Piracicaba as margens do rio Tietè. a $22^{\circ} 48^{\prime}$ de latitude Sul, $48^{\circ} 07^{\prime}$ de longitude oeste, e altitude de aproximadamente 469 metros.

O experimento foi conduzido em solo de cerrado, sem correção. Não foram realizadas adubações durante o ensaio.

\subsection{Caracterização do material}

Todas as etnovariedades foram caracterizadas através de descritores morfológicos, químicos e agronòmicos, relacionados a seguir:

\subsubsection{Características morfológicas}

As características morfológicas utilizadas seguiram a relação de descritores selecionados por Cury (1993), com adição de dois novos descritores, a saber: superficie da película externa da raiz e orientação predominante das raizes.

1. Cor do broto foliar:

1. verde

2. verde arroxeado

3. roxo

2. Cor da folha adulta: 
1. roxo

2. verde claro

3. verde escuro

3. Cor do peciolo de folhas adultas:

1. verde

2. verde avermelhado

3. rosa

4. vinho

5. roxo

4. Morfologia do lóbulo foliar:

1. lanceolada

2. reta

3. pandurada

4. obovada

5. Comprimento do pecíolo.

6. Comprimento do lóbulo médio foliar.

7. Largura do lóbulo médio foliar.

8. Pedículo - Cordão lenhoso que liga a raiz a maniva mãe:

1. presente

2. ausente

9. Cintas - constrições ou estrangulamentos ao longo das raízes:

1. presente 


\section{2. ausente}

10. Superficie da película externa da raiz:

1. lisa

2. rugosa

11. Cor da película da raiz - casca externa de células suberificadas:

1. creme

2. marrom claro

3. marrom escuro

4. roxa

12. Cor da entrecasca

1. branca

2. creme

3. amarela

4. rosa

5. roxa

13. Cor da polpa da raiz:

1. branca

2. creme

3. amarela

4. rosa

5. roxa

14. Orientação predominantes das raizes:

1. vertical 
2. horizontal

3. irregular

\subsubsection{Características agronômicas}

15. Peso fresco de raizes: peso médio por planta em $\mathrm{kg}$, equivalente a $\mathrm{kg} / \mathrm{m}^{2}$

16. Peso da parte aerea: peso médio por planta do caule mais folhas no momento da colheita, em kg.

17. Índice de colheita: relação do peso de raizes sob o peso total da planta.

18. Número total de raizes tuberosas por planta.

19. Produção de amido: em kg por planta.

$$
\text { A S }=P R(\mathrm{~kg} / \mathrm{pl}) \times((100-\mathrm{UPR}) / 100) \times(\mathrm{AR} / 100) \text {. }
$$

onde: PR, é peso de raizes, UPR, é teor de umidade da polpa (\%) e AR, é teor de amido na base seca $(\%)$.

\subsubsection{Características químicas.}

As análises quimicas foram realizadas no CERAT - UNESP em Botucatu.

As análises de folhas se referem a folhas sem peciolo e as análises de raizes quando não especificadas se referem a polpa mais entrecasca, isto é raizes sem a película externa. 
20. Potencial cianogènico nas folhas: $\mathrm{em} \mathrm{mg} / \mathrm{kg}$ na base seca.

21. Ácido cianidrico livre nas folhas: em $\mathrm{mg} / \mathrm{kg}$ na base seca.

22. Teor de matéria seca nas folhas: em $\%$

23. Teor de proteina nas folhas: em $\%$ na base seca.

24. Teor de matéria graxa nas folhas: em \% na base seca.

25. Teor de cinzas nas folhas: em $\%$ na base seca.

26. Teor de fibras nas folhas: em $\%$ na base seca.

27. Teor de carboidratos nas folhas: em $\%$ na base seca.

28. Teor de umidade no caule: em $\%$.

29. Teor de cinzas no caule: em $\%$ na base seca.

30. Teor de proteinas no caule: em $\%$ na base seca.

31. Teor de fibra do caule: em $\%$ na base seca.

32. Teor de matéria graxa do caule: em $\%$ na base seca.

33. Teor de carboidratos totais no caule: em $\%$ na base seca.

34. Potencial cianogènico na entrecasca da raiz: em $\mathrm{mg} / \mathrm{kg}$ na base seca. 
35. Ácido cianidrico livre na entrecasca da raiz: em $\mathrm{mg} / \mathrm{kg}$ na base seca.

36. Potencial cianogênico na polpa da raiz: em $\mathrm{mg} / \mathrm{kg}$ na base seca.

37. Ácido cianídrico livre na polpa da raiz: $\mathrm{mg} / \mathrm{kg}$ na base seca.

38. Teor de umidade na entrecasca das raizes: em \%.

39. Teor de umidade na polpa das raizes: em $\%$.

40. Teor de proteina nas raizes: em $\%$ na base seca.

41. Teor de amido nas raizes: em \% na base seca.

42. Teor de matéria graxa nas raizes: em $\%$ na base seca.

43. Teor de cinzas nas raizes: em $\%$ na base seca.

44. Teor de fibras nas raizes: em $\%$ na base seca.

45. Teor de açúcar solúvel nas raizes: em \% na base seca.

46. Teor de umidade nas raízes: em $\%$.

\subsection{Avaliação e amostragem}


Com o objetivo de coletar amostras para análise centesimal e de ácido cianidrico. as folhas foram colhidas no dia 22 de maio de 1995. Para avaliação das caracteristicas quimicas, foram colhidas todas as folhas de uma única planta da parcela.

No ato da colheita, foi retirada uma amostra das folhas para análise do ácido cianidrico. Para amostragem utilizou-se de um vazador onde foram amostradas todas as folhas colhidas com minimo de 5 gramas, a amostra foi conservada em vidros com solução extratora mantidas a baixas temperaturas em caixas de isopor com gelo.

As amostragens para análise química do caule e da raiz foram realizadas ao mesmo tempo da avaliação dos descritores agronòmicos. Para adequar a capacidade de processamento do laboratório do CERAT, o material foi colhido em períodos diferentes. O bloco I em 03/10/95, o bloco II em 23/10/95 e o bloco III em 06/1 1/95.

Para os descritores agronômicos, foram avaliadas todas as plantas da parcela individualmente. $\mathrm{Na}$ análise estatistica foram considerados as médias das plantas individuais da parcela.

Para as análises quimicas da raiz, foram coletadas todas as raízes de uma planta da parcelas. As raizes no mesmo dia foram enviadas ao laboratório, onde foram fatiadas e homogeneizadas, de onde amostrou-se para análise centesimal e de ácido cianidrico.

Para as análises quimicas do caule, foram selecionadas porções do caule utilizando os mesmos critérios da seleção de manivas para o plantio. No laboratório o caule foi secado e moído de onde amostrou-se para análise centesimal.

\subsection{Metodologias utilizadas nas análises químicas.}

Para determinação do potencial cianogênico e do teor de ácido cianidrico livre utilizou-se da metodologia enzimática de Cooke (1979), modificada por Essers (1994). 
Para determinação dos teores de umidade, proteinas, matéria graxa, cinzas e amido utilizou-se a metodologia estabelecida pela Association of Official Analytical Chemists (1975).

Para análise do teor de fibras, utilizou-se a metodologia estabelecida American Association of Cereal Chemists (1995).

\subsection{Análises estatísticas.}

\subsubsection{Análise de variância dos descritores com distribuição contínua}

As análises dos descritores contínuos foram divididas em duas etapas: a primeira foi geral. com um modelo simplificado, em que foram realizadas as análises de variância para cada descritor e a análise de covariância para cada par de descritores; e na segunda foram desdobrados as somas de quadrados de tratamentos conforme a roça e a região de coleta das etnovariedades.

As etnovariedades coletadas foram consideradas uma amostragem da população real da roça, pois como demonstram Cury (1993), Martins (1994) e Peroni (1998) no sistema de agricultura autóctone, embora a mandioca seja propagada vegetativamente para cultivo, o sistema de reprodução sexuada ocorre paralelamente e novos recombinantes são gerados, portanto a variabilidade identificada pelo agricultor é uma amostra da população da roça.

\subsubsection{Análise geral, segundo modelo simplificado}

O modelo matemático adotado na análise simplificada de variância foi:

$$
Y_{i j}=m+b_{i}+t_{j}+e_{i j}
$$



onde: $\quad Y_{\mathrm{ij}}$ : valor fenotípico do descritor na parcela $\mathrm{ij}$.
m: media geral do descritor.
$b_{i}$ : efeito do bloco i.
$t_{j}$ : efeito da etnovariedade $\mathrm{j}$.
$\mathrm{e}_{\mathrm{ij}:}$ erro experimental.

Os descritores 15 a 46, com exceção do descritor 27 , foram submetidos a analise de variància individual para cada descritor, conforme o modelo simplificado, com o objetivo de testar as significàncias pelo teste $F$, e estimar os componentes da variância fenotıpica de cada descritor. Segue-se quadro da esperança dos quadrados médios do modelo simplificado:

F.V. GL QM $\quad$ E(QM)

$\begin{array}{llll}\text { Blocos } & 2 & \mathrm{QM}_{12} & \\ \text { Etnovar. (geral) } & 55 & \mathrm{QM}_{11} & \sigma_{E}^{2}+3 \sigma_{G}^{2} \\ & & & \\ \text { Erro (E) } & 110 & \mathrm{QM}_{1} & \sigma_{E}^{2}\end{array}$

Onde:

$\hat{\sigma}_{G}^{2}$ : estimativa da variància genética total.

$\hat{\sigma}_{E}^{2}$ : estimativa da variância ambiental.

Foram ainda estimados os seguintes parâmetros genéticos para cada descritor (Vencovsky \& Barriga, 1992), a saber:

a) Coeficiente de variação genética:

$\mathrm{CV}_{\mathrm{g}}=\hat{\sigma}_{G} / \bar{Y}$, onde $\bar{Y}$ é a média do descritor. 
b) Coeficiente de herdabilidade no sentido amplo ao nível de parcelas:

$$
\hat{h}_{p}^{2}=\hat{\sigma}_{G}^{2} /\left(\hat{\sigma}_{G}^{2}+\hat{\sigma}_{E}^{2}\right)
$$

c) Coeficiente de herdabilidade no sentido amplo ao nível de médias:

$$
\hat{h}_{m}^{2}=\hat{\sigma}_{G}^{2} /\left(\hat{\sigma}_{G}^{2}+\hat{\sigma}_{E}^{2} / \mathrm{r}\right) \text {, onde r é o número de repetições. }
$$

Os parâmetros genéticos estimados referem-se a uma macropopulação, formada por todos os tratamentos avaliados.

O descritor 27 foi descartado devido a perdas de amostras no laboratório, o descritor 18 , número de raízes, foi transformado em $(\sqrt{x+1})$.

Os descritores também foram submetidos a análise de covariância, com o objetivo de estimar as correlações fenotípicas $\left(\mathrm{r}_{\mathrm{F}(\mathrm{x}, \mathrm{y})}\right)$, as correlações genética $\left(\mathrm{r}_{\mathrm{G}(\mathrm{x}, \mathrm{y})}\right)$ e as correlações ambientais $\left(\mathrm{r}_{\mathrm{E}(\mathrm{x}, \mathrm{y})}\right)$ para cada par de descritores. Igualmente a análise de variância, os descritores agronômicos foram representados pela média da parcela e os químicos por uma planta da parcela. As análises foram realizadas no programa Genes, conforme metodologia descrita em Cruz \& Regazzi (1994).

\subsubsection{Desdobramentos da análise de variância.}

O modelo matemático adotado no desdobramento do quadrado médio de tratamentos (etnovariedades) da análise de variância foi:

$$
Y_{i k l m}=m+b_{i}+a_{k}+r_{l(k)}+v_{m(k l)}+e_{i k l m}
$$

onde: $\quad Y_{\mathrm{ik} k \mathrm{~m}}$ : observação fenotípica referente ao bloco i, região $\mathrm{k}$, roça l e etnovariedade $m$. 
$b_{i}$ : efeito do bloco $i$.

$a_{k}$ : efeito da região $k$.

$r_{1(k)}$ : efeito da roça $l$, dentro da região $k$.

$v_{m(k)]}$ : efeito da etnovariedade $m$, dentro da roça $l$, dentro da

região $k$.

$\mathrm{e}_{\mathrm{iklm}}$ : erro experimental.

Primeiramente as somas de quadrados dos tratamentos para os descritores 15 a 46. com exceção do descritor 27 , foram desdobrados segundo o modelo matematico. Os desdobramentos foram estruturados em função da estratégia de coleta das etnovariedades (Tabela 1). Os efeitos de regiões, roças dentro de regiões e etnovariedades dentro de roças dentro de regiões foram considerados efeitos aleatórios. Para o cálculo dos desdobramentos, para a realização do teste $\mathrm{F}$ e para o cálculo das estimativas das variâncias, utilizou-se o programa SAS (Statistical Analysis System). Na analise dos desdobramentos, a variedade padrão I.A.C. Mantiqueira foi englobada na região 3 .

Segue quadro da esperança dos quadrados médios do desdobramento:

F.V. GL QM E(QM)

Regiões (A) $2 \quad \mathrm{QM}_{10} \quad \sigma_{E}^{2}+3 \sigma_{v^{\prime} / R / A}^{2}+12,316 \sigma_{R / A}^{2}+50,357 \sigma_{A}^{2}$

Roças/A $\quad 14 \quad \mathrm{QM}_{9} \quad \sigma_{E}^{2}+3 \sigma_{V / R / A}^{2}+9,070 \sigma_{R / A}^{2}$

Etonvar/R/A $39 \quad \mathrm{QM}_{8} \quad \sigma_{E}^{2}+3 \sigma_{V / R / A}^{2}$

Erro (E) $\quad 110 \quad \mathrm{QM}_{1} \quad \sigma_{E}^{2}$

Onde:

A: regiões; R: roças; V: etnovariedades 
$\hat{\sigma}_{*}^{2} R_{\text {. }}$ : estimativa da variància genética entre etnovariedades, dentro de roças, dentro de regiões.

$$
\begin{aligned}
& \hat{\sigma}_{R .1}^{2} \text { : estimativa da variância genética entre roças, dentro de regiões. } \\
& \hat{\sigma}_{A}^{2} \text { : estimativa da variância genética entre regiões. } \\
& \hat{\sigma}_{E}^{2} \text { : estimativa da variância ambiental. }
\end{aligned}
$$

Em seguida, o desdobramento foi realizado para cada região individualmente conforme os quadros da esperança dos quadrados médios abaixo relacionados:

a. Para a região 1 (A1), Rio Negro - Bacia Amazônica:
F. V.
GL QM E(QM)

Roças/AI

$6 \quad \mathrm{QM}$

$\sigma_{E}^{2}+3 \sigma_{V / R / A 1}^{2}+11,500 \sigma_{R / A 1}^{2}$

Etnovar/R/Al

$23 \mathrm{QM}_{6} \quad \sigma_{E}^{2}+3 \sigma_{V: A 1}^{2}$

Erro (E)

$110 \quad \mathrm{QM}_{1} \quad \sigma_{E}^{2}$

Onde:

$\hat{\sigma}_{\}_{R / A 1}}^{2}$ : estimativa da variància genética entre etnovariedades, dentro de roças, dentro da região Al.

$$
\hat{\sigma}_{R: A 1}^{2} \text { : estimativa da variância genética entre roças, dentro da região }
$$
A1. 
b. Para a região 2 (A2), Rio Solimões - Bacia Amazônica:

\section{F.V. GL $\quad$ QM $\quad \mathrm{E}(\mathrm{QM})$}

Roças/A2 $3 \quad \mathrm{QM}_{5} \quad \sigma_{E}^{2}+3 \sigma_{V / R / A 2}^{2}+11,125 \sigma_{R / A 2}^{2}$

Etnovar/R/A2 $12 \quad \mathrm{QM}_{4} \quad \sigma_{E}^{2}+3 \sigma_{V / R / A 2}^{2}$

Erro (E) $\quad 110 \quad \mathrm{QM}_{1} \quad \sigma_{E}^{2}$

Onde:

$\hat{\sigma}_{V^{\prime} / R / A 2}^{2}$ : estimativa da variância genética entre etnovariedades, dentro de roças, dentro da região A2.

$\hat{\sigma}_{R / d 2}^{2}$ : estimativa da variância genética entre roças, dentro da região A2.

c. Para a região 3 (AL), litoral sul - SP.

F.V.

GL QM $\quad \mathrm{E}(\mathrm{QM})$

Roças/A3 $5 \quad \mathrm{QM}_{3} \quad \sigma_{E}^{2}+3 \sigma_{V / R / A 3}^{2}+4,920 \sigma_{R / A 3}^{2}$

Etnovar/R/A3 $4 \quad \mathrm{QM}_{2} \quad \sigma_{E}^{2}+3 \sigma_{V / R / A 3}^{2}$

Erro (E) $\quad 110 \quad \mathrm{QM}_{1} \quad \sigma_{E}^{2}$

Onde:

$\hat{\sigma}_{V^{\prime} / A j}^{2}$ : estimativa da variância genética entre etnovariedades, dentro de roças, dentro da região $\mathrm{A} 3$.

$\hat{\sigma}_{R / A 3}^{2}$ : estimativa da variância genética entre roças, dentro da região A3. 


\subsubsection{Estimativas da divergência genética multivariada entre as etnovariedades.}

Para os descritores 15 a 46, que apresentaram distribuição contínua e que foram avaliados em delineamento com repetição, estudou - se a divergência genética entre as etnovariedades através dos seguintes métodos:

a. Distància generalizada de Mahalanobis.

b. Variàveis canônicas.

c. Algoritmo UPGMA, método não ponderado de agrupamento aos pares usando medias aritmeticas. Como medida de dissimilaridade, foi utilizada distância de Mahalanobis.

Os procedimentos a. e b. foram feitos de acordo com Cruz \& Regazzi (1994). Para o cálculo utilizou-se do programa Genes e para a saída gráfica o Statistica for Windows, v. 4.3.

O procedimento c. encontra-se descrito em Curi (1983) e Sneath \& Sokal (1973), para a saida gráfica utilizou-se o programa Statistica for Windows, v. 4.3. 


\section{RESULTADOS E DISCUSSĀO}

\subsection{Caracterização das etnovariedades}

Na Tabela 2. estão representados as características morfológicas, agronòmicas e químicas das etnovariedades avaliadas, perfazendo um total de 55 descritores. O descritor 27 , teor de carboidratos nas folhas, foi descartado das análises estatisticas. por problemas de perda de dados no laboratório.

O ensaio de campo foi muito bom, pois na experimentação da mandioca com genotipos muito variáveis, não é fácil conduzir bons experimentos, e neste caso apesar da diversidade manejada, não ocorreram perda de parcelas.

\subsubsection{Caracterização morfológica}

$\mathrm{Na}$ Tabela 3, estão discriminados a média e a freqüência dos estados para os descritores morfológicas de 1 a 4 e de 8 a 14. Observa-se que a região com maior numero de estados, se consideradas todas as variáveis, é a região 1 com 31 , seguida da região 2 com 29 e da região 3 com 28 . As três regiões em conjunto apresentaram 32 dos 38 estados avaliados. Observa-se também que é muito dificil relacionar características morfológicas com determinadas regiões, porém é claro a predominância nas regiões amazònicas de raizes amarelas, o que deve estar relacionado a preferência de farinha de cor amarela nestas regiões. 
Outra questão que podemos observar com relação as variáveis morfologicas discretas é a presença de endemismo e de estados raros.

Nota-se que poucos estados dos descritores são endêmicos: o estado 3 (raiz com pelicula marrom escuro) do descritor 11, para a região 2; e o estado 3 (distribuição irregular das raizes) do descritor 14, para a região 1 .

Os estados raros ou com baixa freqüência para todas as regiões foram: o estado 4 (folha obovada) do descritor 4; o estado 3 (raiz com película marrom escuro) do descritor 11: o estado 5 (raiz com entrecasca roxa) do descritor 12 e o estado 3 (distribuição irregular das raizes) do descritor 14. Neste caso os endêmicos também foram raros (Tabela 3)

Portanto. a variabilidade com relação aos descritores morfológicos discretos e ampla e distribuida entre as regiões amostradas, sendo que a região 1 apresenta $81.58 \%$ de todos os estados avaliados, a região $2,76,32 \%$ e a região 3 , $73,68 \%$. Se considerarmos ambas regiões da bacia amazônica temos representação de $84.21 \%$ dos descritores analisados.

A média, o mínimo, o máximo e o desvio padrão dos descritores morfologicos continuos 5 (comprimento do peciolo), 6 (comprimento do lóbulo médio), e 7 (largura do lóbulo medio) estão representados na Tabela 4.1. O comprimento do peciolo variou de 18.75 (DG-111, Reg. 2) a 45,00 (DG130, Reg. 3) com média 30,16 e desvio padrão 6,17. O comprimento do lóbulo médio variou de 15,45 (DG-42, Reg. 1) a 28,85 (DG-69, Reg. 1) com media de 20,32 e desvio padrão 3,10. A largura do lóbulo médio variou de 1,35 (DG-122, Reg. 2) a 7,20 (DG-133, Reg. 3) com média de 4,72 e desvio padrão de 1,25 .

Comparando os dados dos descritores morfológicos contínuos com outros obtidos na literatura percebe-se que a variabilidade aqui encontrada é grande. Pereira (1989) avaliando 280 acessos do banco de germoplasma da Embrapa - CNPMF encontrou desvio padrão de 1,89 para comprimento do lóbulo e de 0,76 para largura do lóbulo, bem inferiores aos determinados no presente caso apesar do número muito inferior de acessos avaliados. A variabilidade também é superior a encontrada por Cury 
(1993) que encontrou desvio padrão de 3,33 para comprimento do peciolo, 1,82 para comprimento do lóbulo médio, e de 1,30 para largura do lóbulo médio, avaliando 30 etnovariedades provenientes do litoral sul e vale do Rio Ribeira, no Estado de São Paulo.

Convém ressaltar que os descritores morfológicos apresentam limitações no estudo da diversidade genética, pois muitos deles são influenciados ou determinados por apenas um alelo o que pode levar a conclusões errôneas a respeito da diversidade entre materiais quando utilizados isoladamente. Por outro lado, estes descritores não podem ser desprezados. pois além da importância econòmica são também muito importantes na taxonomia popular da mandioca. Os indios, caboclos e caiçaras utilizam estes descritores para diferenciação das etnovariedades.

\subsubsection{Caracterização agronômica}

Na Tabela 4.1, estão representados a média, o mínimo, o máximo e o desvio padrão para os descritores agronòmicos 15 (peso fresco de raizes), 16 (peso da parte aerea), 17 (indice de colheita), 18 (número total de raizes por planta) e 19 (produção de amido). Nas Tabelas 5.1 e 6 , estão encontram-se, respectivamente, os resultados da analise de variância e as estimativa dos parâmetros genéticos para os mesmos descritores. Nas Tabelas 7, 8, 9, 10 e 11, estão os resultados do teste de Tukey a $5 \%$ de probalidade para os descritores $15,16,17,18$ e 19 , respectivamente.

\subsubsection{Produção de raízes, em kg/pl}

O descritor 15, peso fresco de raizes, apresentou mínimo de 0,407 (DG54, Reg. 1), máximo de 5,493 (DG-127, Reg. 3), amplitude de 5,086, média de 2,072 e desvio padrão de 1,233 (Tabela 4.1). O coeficiente de variação ambiental $\left(\mathrm{CV}_{\mathrm{e}}\right)$ foi muito alto, $34,46 \%$. As diferenças entre as etnovariedades foram significativas (Tabela 5.1). A 
diferença minima significativa entre as médias pelo teste de Tukey a $5 \%\left(\Delta_{5 \%}\right)$ de probabilidade foi de 2.431 (Tabela 7). Os paràmetros genéticos estimados foram de $88.82 \%$ para herdabilidade no sentido amplo ao nivel de médias $\left(\hat{h}_{m}^{2}\right), 72,60 \%$ para a herdabilidade no sentido amplo ao nivel de parcelas $\left(\hat{h}_{p}^{2}\right), 56,09 \%$ para o coeficiente de variação genetica $\left(\mathrm{CV}_{g}\right)$ e 1,62 para razão coeficiente de variação genética e coeficiente de variação ambiental $\left(\mathrm{CV}_{\mathrm{g}} / \mathrm{CV}_{\mathrm{e}}\right)$.

A variação genética foi preponderante na variação fenotípica e a variabilidade genetica em relação a média foi alta. O desvio padrão genético foi 1,62 vezes superior ao desvio padrão ambiental, o que não é comum para o caráter produção de raizes (Tabela 6 )

Comparando-se com a variedade padrão IAC- Mantiqueira, observaram-se 12 etnovariedades no mesmo patamar de produtividade, quando considerada a discriminação pelo teste de Tukey (Tabela 7). Devido a precisão do ensaio, a diferença minima significativa $\left(\Delta_{s^{\circ}}\right)$ foi muito alta, o que representa mais de 24 toneladas por hectare. portanto outro ensaio com melhor precisão poderá discriminar materiais com produtividade superior ao padrão.

As etnovariedades provenientes da região 3 apresentaram maior produção media com 3,897, seguida da região 2 com 2,010 e por último a região 1 com 1,497 (Tabela 4.1). Por um lado pode-se considerar que a região 3 concentra materiais mais produtivos para as condições ambientais do ensaio do que as outras, mas por outro lado, nota-se na Tabela 7 que do grupo elite das 12 etnovariedades determinado pelo teste de Tukey, 4 são provenientes da região 1 (Rio Negro), justamente a região onde concentra o maior numero de materiais inferiores, e 1 da região 2 (Rio Solimões).

Uma boa hipótese seria atribuir a maior produtividade média do material do litoral sul paulista ou a menor do material do Rio Negro, nas condições ambientais de Piracicaba - SP, a uma questão de adaptabilidade. O modelo evolutivo da mandioca (Cury, 1993; Martins, 1994) propõe que as etnovariedades estariam constantemente sofrendo forte seleção natural e humana, o que poderia levar a predominància de 
genótipos com adaptação local. De qualquer forma, a interação com o ambiente destes genótipos merece ser investigada profundamente.

A variabilidade da mandioca para o caráter produção de raízes, mantida na agricultura tradicional, é ampla e também útil ao melhoramento da mandioca pois mantém genótipos com produtividade comparável a variedades comerciais.

\subsubsection{Peso da parte aérea, em kg/pl}

O descritor 16, peso da parte aérea, apresentou mínimo de 0,867 (DG-41, Reg. 1), máximo de 6,843 (DG-134, Reg. 3), amplitude de 5,976, média de 2,738 e desvio padrão de 1,271 (Tabela 4.1). $\mathrm{O} \mathrm{CV}_{\mathrm{e}}$ foi muito alto, 35,45\%. As diferenças entre as etnovariedades foram significativas (Tabela 5.1). A diferença mínima significativa entre as médias pelo teste de Tukey a $5 \%\left(\Delta_{5 \%}\right)$ de probabilidade foi de 3,3038 (Tabela 8 ). Os paràmetros genéticos estimados foram de $80,55 \%$ para herdabilidade no sentido amplo ao nível de médias $\left(\hat{h}_{m}^{2}\right), 58,00 \%$ para herdabilidade no sentido amplo ao nível de parcelas $\left(\hat{h}_{p}^{2}\right), 41,66 \%$ para o coeficiente de variação genética $\left(C_{\mathrm{g}}\right)$ e de 1,17 para razão coeficiente de variação genética e coeficiente de variação ambiental $\left(\mathrm{CV}_{\mathrm{g}} / \mathrm{CV}_{\mathrm{c}}\right)$

Neste a caso, a variação genética também foi preponderante na variação fenotípica, e a variabilidade genética expressa pelo $\mathrm{CV}_{\mathrm{g}}$, se comparada a dados da literatura, é alta (Acosta Espinoza, 1984), mas relativamente inferior se comparada ao caráter produção de raízes. O desvio padrão genético foi 1,17 vezes superior ao desvio padrão ambiental, o que significa, que nas condições do ensaio, o descritor peso da parte aérea foi mais influenciado pelo ambiente que o descritor peso de raízes.

Novamente, as etnovariedades provenientes da região 3 apresentaram maior média com 3,954, seguida da região $2 \operatorname{com} 2,827$ e da região 1 com 2,284, mas as diferenças entre estas médias foram inferiores às encontradas para o descritor peso de 
raizes (Tabela 4.1). Das 10 etnovariedades que formaram o grupo com maior peso da parte aérea (Tabela 8), 4 são provenientes da região 3, 3 da região 1 e 3 da região 2 . Nem sempre as etnovariedades com maior peso na parte aérea apresentaram boa produção de raizes, como as etnovariedades DG56 e DG47 .

\subsubsection{Indice de colheita}

O descritor 17, indice de colheita, apresentou minimo de 0,2290 (DG-54, Reg. 1), máximo 0,6277 (DG-126, Reg. 3), amplitude de 0,3987, média de 0,416 e desvio padrão de 0,093 (Tabela 4.1) O $\mathrm{CV}_{\mathrm{e}}$ foi médio, 14,76. As diferenças entre as etnovariedades foram significativas (Tabela 5.1). A diferença minima significativa entre as médias pelo teste de Tukey a $5 \%\left(\Delta_{5 \%}\right)$ de probabilidade foi de 0,2086 (Tabela 9).Os parâmetros genéticos estimados foram de $85,58 \%$ para herdabilidade no sentido amplo ao nível de médias $\left(\hat{h}_{m}^{2}\right), 66,46 \%$ para herdabilidade no sentido amplo ao nível de parcelas $\left(\hat{h}_{p}^{2}\right)$, 20,78 para o coeficiente de variação genética $\left(\mathrm{CV}_{\mathrm{g}}\right)$ e de 1,41 para razão coeficiente de variação genética e coeficiente de variação ambiental $\left(\mathrm{CV}_{\mathrm{g}} / \mathrm{CV}_{\mathrm{e}}\right)$.

$O$ indice de colheita representa a relação entre o peso das raizes e o peso total da planta. Neste caso, novamente a variância genética entre as etnovariedades foi predominante na variância fenotipica. As estimativas dos coeficientes de herdabilidade foram intermediária em relação aos descritores peso de raizes e peso da parte aérea. Já variabilidade genética em relação a média, expressada pelo $\mathrm{CV}_{\mathrm{g}}$, foi inferior se comparada aos anteriores.

As etnovariedades provenientes da região 3 apresentaram maior média com 0,516 , seguida da região 2 com 0,415 e da região 1 com 0,383 (Tabela 4.1).

Comparando-se com a variedade padrão IAC- Mantiqueira, observaram-se 25 materiais no mesmo patamar, quando considerada a discriminação pelo teste de Tukey. Embora o teste de Tukey não tenha discriminado, observaram-se também 12 
etnovariedades com média superior ao padrão, destas 6 eram provenientes da região 3,3 da região 1 e 3 da região 2 (Tabela 9), o que significa que o germoplasma com potencial para melhoramento deste caractere está distribuido nas três regiões.

Nem sempre as etnovariedades com melhores indices de colheita apresentam melhor produção de raizes. Por exemplo, as etnovariedades DG129, DG122, DG131, DG115 e DG123 não estão incluidas no grupo superior de peso de raízes por planta (Tabela 7).

É importante ressaltar que os dados de produção de raizes foram expressos em Kg por planta obtidos num espaçamento de $1 \mathrm{~m} \times 1 \mathrm{~m}$. Portanto, alterações no espaçamento alterarão a produtividade de raizes. Neste sentido, tem-se etnovariedades que devem ser melhor avaliadas, devido ao seu potencial para o aproveitamento no melhoramento da mandioca para produtividade, como por exemplo as variedades DG126, DG127 e DG128 da região 3 e DG38, DG65 e DG67 da região 1.

\subsubsection{Número de raizes}

O descritor 18 , número total de raizes por planta transformado em $\sqrt{\mathrm{x}+1}$, apresentou minimo de 1,893 (DG-121, Reg. 2), máximo de 3,633 (DG-127, Reg. 3), amplitude de 1,740, média de 2,741 e desvio padrão de 0,446 (Tabela 4.1). O coeficiente de variação ambiental $\left(\mathrm{CV}_{\mathrm{e}}\right)$ foi baixo, $10,07 \%$. As diferenças entre as etnovariedades foram significativas (Tabela 5.1). A diferença minima significativa entre as médias pelo teste de Tukey a $5 \%\left(\Delta_{5 \%}\right)$ de probabilidade foi de 0,873 (Tabela 10 ). Os parâmetros genéticos estimados foram de $88,97 \%$ para herdabilidade no sentido amplo ao nível de médias $\left(\hat{h}_{m}^{2}\right), 72,90 \%$ para a herdabilidade no sentido amplo ao nível de parcelas $\left(\hat{h}_{p}^{2}\right), 15,34 \%$ para o coeficiente de variação genética $\left(\mathrm{CV}_{\mathrm{g}}\right)$ e 1,63 para razão coeficiente de variação genética e coeficiente de variação ambiental $\left(\mathrm{CV}_{\mathrm{g}} / \mathrm{CV}_{\mathrm{e}}\right)$. 
A média do descritor 18 sem transformação foi de 6,71 , o mínimo de 2,58 e o máximo de 12,20. Na Tabela 10 , foram relacionadas as média originais e transformadas.

Novamente, a variância genética foi predominante na variância fenotípica. O desvio padrão genético foi 1,63 vezes superior ao desvio padrão residual. Já variabilidade genética em relação a média, expressa pela $\mathrm{CV}_{\mathrm{g}}$, foi a mais baixa de todos os descritores agronòmicos.

A região 3 apresentou a maior média real com 9,35, seguida da região 2 com 7,17 e da região 1 com 5,22. Houve relação direta entre os descritores peso de raízes e número de raízes, pois todas as etnovariedades mais produtivas apresentam elevado número de raízes. As correlações entre os descritores serão detalhadas mais adiante.

\subsubsection{Produção de amido, $\mathrm{Kg} / \mathrm{pl}$.}

O descritor 19 , produção de amido, foi obtido com propósito prático devido ao crescente interesse econômico na produção do amido a partir da mandioca.

O descritor apresentou média de 2,050, mínimo de 0,103 (DG-54, Reg. 1), máximo de 2,050 (DG-127, Reg. 3) e amplitude de 1,947. (Tabela 4.1). O coeficiente de variação ambiental $\left(\mathrm{CV}_{\mathrm{e}}\right)$ foi muito alto, $36,35 \%$. As diferenças entre as etnovariedades foram significativas (Tabela 5.1). A diferença mínima significativa entre as médias pelo teste de Tukey a $5 \%\left(\Delta_{5 \%}\right)$ de probabilidade foi de 0,9037 (Tabela 11). Os parâmetros genéticos estimados foram de $90,32 \%$ para herdabilidade no sentido amplo ao nível de médias $\left(\hat{h}_{m}^{2}\right), 75,68 \%$ para a herdabilidade no sentido amplo ao nível de parcelas $\left(\hat{h}_{p}^{2}\right)$, 64,14\% para o coeficiente de variação genética $\left(\mathrm{CV}_{\mathrm{g}}\right)$ e de 1,76 para razão coeficiente de variação genética e coeficiente de variação ambiental $\left(\mathrm{CV}_{g} / \mathrm{CV}_{e}\right)$.

Observa-se, nas Tabelas 7 e 11, que a distribuição das etnovariedades com maior peso de raizes é parecida com a produção de amido. Isto deve-se ao fato que a 
amplitude de variação é muito superior no caso do peso de raizes, que acaba se sobrepondo aos outros descritores que compõe o descritor peso de amido.

Comparando os paràmetros genéticos deste caráter com os obtidos para produção de raizes, percebe-se que todos os parâmetros obtidos para produção de amido foram superiores, portanto com objetivo para seleção de genótipos para produção de amido (fécula) é mais eficiente utilizar este caráter.

A região 3 apresentou a maior média com 1,496, seguida da região 2 com 0,702 e da região 1 com 0,496 (Tabela 4.1). Comparando com o padrão, foram observadas várias etnovariedades que podem apresentar potencial de produção superior, embora neste caso o teste de comparação de médias não tenha detectado (Tabela 11).

\subsubsection{Relação com a domesticação da mandioca da variabilidade e herança dos caracteres agronômicos}

É claro, na domesticação da mandioca, que os caracteres agronômicos foram alterados. O peso de raizes e o índice de colheita foram favorecidos, o número de raizes tuberosas provavelmente também. A modalidade de seleção utilizada pelos agricultores autóctones na domesticação e seleção de novas etnovariedades foi e ainda é a seleção massal, modalidade que não apresenta controle sobre os efeitos ambientais, e que portanto, é de baixíssima eficiência em características de baixa herdabilidade.

A magnitude dos coeficientes de herdabilidade encontrados, ressalvandose que foram calculados para toda população e não para a unidade evolutiva que é a roça (Cury, 1993), explica a viabilidade da seleção massal e talvez ganhos expressivos podem ter sido conseguidos em um número de gerações inferior ao que pudéssemos imaginar anteriormente. 


\subsubsection{Caracterização química: ácido cianídrico}

\subsubsection{Potencial cianogênico e teor de ácido cianídrico livre nas folhas, $\mathrm{mg} / \mathrm{kg}$ na base seca}

O descritor 20, potencial de ácido cianídrico nas folhas, apresentou média de 1105,0, mínimo de 393,8 (DG-65, Reg.1), máximo de 2017,2 (DG-70, Reg. 1) e amplitude de 1623,4 (Tabela 4.1). As diferenças entre as etnovariedades foram significativas, o coeficiente de variação ambiental $\left(\mathrm{CV}_{\mathrm{e}}\right)$ foi muito alto, 39,19 (Tabela $5.1)$.

O ácido cianídrico potencial representa todo cianeto da folha, na forma livre ou como radical dos glicosidios linamarina e lotaustralina. O potencial cianídrico da folha determinado para o conjunto de etnovariedades foi muito alto. A média do potencial das folhas foi 8,7 vezes superior a média do potencial da entrecasca e 35,9 vezes superior a média do potencial da polpa (Tabelas 4.1 e 4.2). A superioridade do potencial cianogênico nas folhas é fato conhecido (Bokanga, 1994), mas neste caso o que impressiona é a magnitude da superioridade. Por outro lado, não pode-se deixar de ressalvar que os descritores relacionado a folha e a raizes foram medidos em periodos distintos.

Numericamente, a amplitude de variação entre as etnovariedade foi alta, mas devido ao alto $\mathrm{CV}_{\mathrm{e}}$ e a baixa herdabilidade (Tabela 6), apenas as duas primeiras etnovariedades com maior potencial, DG70 $(2017,2)$ e DG48 $(1868,6)$, diferiram estatisticamente (Tabela 12) da etnovariedade com menor potencial, DG65.

A variabilidade genética expressa pelo $\mathrm{CV}_{\mathrm{g}}$ foi mediana, mas a variância ambiental foi preponderante na variância fenotípica e o desvio padrão ambiental foi cerca de 1,82 vezes superior ao desvio padrão genético. Portanto, a variação entre as etnovariedades descrita pela variável foi mais de natureza ambiental do que genética.

O descritor 21, ácido cianídrico livre nas folhas, apresentou média de 192,70, mínimo de 44,2 (DG-120, Reg. 2), máximo de 389,3 (DG-73, Reg. 1) e 
amplitude 345,17 (Tabela 4.1). As diferenças entre as etnovariedades foram significativas, e o coeficiente de variação ambiental foi muito alto, 41,51\% (Tabela 5.1)

O teor de ácido cianídrico livre nas folhas representa a concentração do ín $\mathrm{CN}$ livre no momento da análise, o que significa que em média $17,44 \%$ do potencial nas folhas já estava livre no momento da análise. Comparando os dados das Tabelas 12 e 13 nota-se que a relação livre potencial apresenta grande variação fenotípica, variando de $5,63 \%$ (DG120) a 35,20\% (DG117). O teor determinado foi muito alto, e em média foi 1,5 vezes superior ao potencial da entrecasca da raiz e 16 vezes ao ácido cianídrico livre da entrecasca (Tabelas 4.1 e 4.2).

Igualmente ao potencial, o teor de ácido cianídrico livre apresentou ampla variação fenotípica mas a natureza da variação foi mais devida a fatores ambientais do que genéticos. O desvio padrão ambiental foi 1,52 vezes superior ao desvio padrão genético (Tabela 6). A variabilidade genética representada pelo $\mathrm{CV}_{\mathrm{g}}$ foi mediana.

A comparação das médias entre as regiões 1,2 e 3 para ambos os descritores revelou diferenças muito pequenas

Tanto o teor de ácido cianídrico livre quanto o potencial cianogênico nas folhas foram muito altos, o que impossibilita a utilização de qualquer uma destas etnovariedades para o consumo humano ou animal sem processamento para eliminação do HCN. No Brasil, as folhas de mandioca são tradicionalmente consumidas na alimentação humana apenas na região amazônica no preparo da maniçoba (Albuquerque \& Cardoso, 1980). O preparo envolve a moagem das folhas verdes e o posterior cozimento por dois dias, o que acaba eliminando a possibilidade de intoxicação.

\subsubsection{Potencial cianogênico na entrecasca e na polpa das raizes, $\mathrm{mg} / \mathrm{kg}$ na base seca}

O descritor 34, potencial cianogênico na entrecasca (casca primária, córtex) das raizes, apresentou média de 126,77, mínimo de 45,68 (DG-68, Reg.1), 
máximo de 340,65 (DG-43, Reg. 1) e amplitude de 294,970 (Tabela 4.2). As diferenças entre as etnovariedades foram significativas. $\mathrm{O}$ coeficiente de variação ambiental $\left(\mathrm{CV}_{\mathrm{e}}\right)$ foi médio, 12,89\% (Tabela 5.3). A diferença mínima significativa entre as médias pelo teste de Tukey a $5 \%\left(\Delta_{5^{\circ}}\right)$ de probabilidade foi de 55,633 (Tabela 24 ). Os parâmetros genéticos estimados (Tabela 6 ) foram de $98,58 \%$ para herdabilidade no sentido amplo ao nivel de médias $\left(\hat{h}_{m}^{2}\right), 95,86 \%$ para a herdabilidade no sentido amplo ao nivel de parcelas $\left(\hat{h}_{p}^{2}\right), 62,04 \%$ para o coeficiente de variação genética $\left(\mathrm{CV}_{\mathrm{g}}\right)$ e de 4,81 para razão coeficiente de variação genética e coeficiente de variação ambiental $\left(\mathrm{CV}_{\mathrm{g}} / \mathrm{CV}_{\mathrm{e}}\right)$.

$\mathrm{O}$ descritor 36 , potencial cianogênico na polpa (parênquima) das raizes apresentou média de 30,769, mínimo de 8,410 (DG-61, Reg.1), máximo de 89,450 (DG44, Reg. 1) e amplitude de 81,040 (Tabela 4.2). As diferenças entre as etnovariedades foram significativas. $\mathrm{O}$ coeficiente de variação ambiental $\left(\mathrm{CV}_{\mathrm{e}}\right)$, foi alto, 20,67\% (Tabela 5.3). A diferença mínima significativa entre as médias pelo teste de Tukey a $5 \%\left(\Delta_{5 \%}\right)$ de probabilidade foi de 21,65 (Tabela 26). Os parâmetros genéticos estimados (Tabela 6) foram de $95,04 \%$ para herdabilidade no sentido amplo ao nível de médias $\left(\hat{h}_{m}^{2}\right), 86,47 \%$ para a herdabilidade no sentido amplo ao nivel de parcelas $\left(\hat{h}_{p}^{2}\right), 52,57 \%$ para o coeficiente de variação genética $\left(\mathrm{CV}_{\mathrm{g}}\right)$ e de 2,52 para razão coeficiente de variação genética e coeficiente de variação ambiental $\left(\mathrm{CV}_{\mathrm{g}} / \mathrm{CV}_{\mathrm{e}}\right)$.

O potencial cianogènico na raiz da mandioca da mandioca é um dos temas mais interessantes e mais curiosos relacionados a mandioca, inclusive no passado variedades agrupadas como "bravas" e "mansas" foram agrupadas em espécies distintas. Anteriormente a mesma característica era denominada teor de ácido cianídrico total ou simplesmente teor de ácido cianídrico.

No geral, os teores da polpa foram muito baixos. Segundo o critério proposto por Kock (1933), pode-se considerar nas condições do ensaio que todas as etnovariedades são inócuas, já que o máximo $89,450 \mathrm{mg} / \mathrm{kg}$ na base seca representa cerca de $37,0 \mathrm{mg} / \mathrm{kg}$ de polpa crua, portanto inferior a $50 \mathrm{mg} / \mathrm{kg}$ na polpa crua. Os dados estão 
de acordo com Bokanga (1994) que concluiu que a maioria dos genótipos da mandioca apresentam baixo potencial cianogênico.

Observa-se na Tabela 26, que não há concordância entre o uso das etnovariedades pelas populações tradicionais e o potencial cianogênico da polpa. Por exemplo as etnovariedades utilizadas para mesa DG39, DG129 e DG128 apresentaram potencial cianogênico estatisticamente superior a muitas etnovariedades cujo uso era farinha. Provavelmente o uso da mandioca pelas populações tradicionais seja determinado por outros fatores além do potencial cianogênico, como sabor, cor e cozimento.

Todas etnovariedades apresentaram potencial cianogênico da entrecasca superior ao da polpa (Tabelas 24 e 26). A média do potencial cianogênico da entrecasca foi 4,12 vezes superior a da polpa e o mínimo da entrecasca foi 1,5 vezes superior a média da polpa. A relação entre o potencial da entrecasca e o da polpa, na mesma etnovariedade, não foi linear, variando de 1,35 (DG39, Reg. 1) a 15,29 (DG130, Reg. 3).

Mesmo sendo superior ao da polpa, o potencial cianogênico da entrecasca não foi alto. A maioria das etnovariedades avaliadas apresentou potencial cianogênico da entrecasca inferior a $100 \mathrm{mg} / \mathrm{kg}$ na base fresca, o que equivale ao redor de $250 \mathrm{mg} / \mathrm{kg}$ na base seca. Além disso no que se refere a intoxicação, o peso relativo da entrecasca nas raizes é baixo.

Outro aspecto que interfere na possibilidade de intoxicação é a remoção da entrecasca no preparo. Por exemplo no Estado de São Paulo é comum a remoção da entrecasca no preparo de pratos com a mandioca, já os índios Tukâno da Colômbia não a removem (Dufour, 1988).

Para ambos os potenciais, a $\hat{h}_{m}^{2}$ e a $\hat{h}_{p}^{2}$ foram altas. Para o potencial cianogênico da entrecasca o desvio padrão genético foi 4,81 vezes superior ao desvio padrão ambiental e para potencial cianogênico da polpa foi 2,52 vezes superior (tabela 6). $\mathrm{O}$ que demonstra, que para as condições do ensaio, a variação genética foi altamente preponderante na variação fenotípica. As estimativas da herdabilidade determinadas foram superiores as encontradas por Dixon et al (1994). 
Para o potencial cianogênico da polpa, a região 1 apresentou a maior média com 35,114, seguida da região 3 com 27,619 e da região 2 com 25,724 . Já para o potencial cianogênico da entrecasca, a região 3 apresentou maior média com 155,062, seguida da região 2 com 137,055 e da região 1 com 113,129. Devido a magnitude da interação genótipo ambiente do potencial cianogênico (Bokanga et al.; 1994, Dixon et al.,1994), é temerário extrapolar os resultados obtidos para outros ambientes. Entretanto, nas condições experimentais o material amazônico, conhecido empiricamente como extremamente bravo, não apresentou potencial diferente do material paulista.

\subsubsection{3. Ácido cianídrico livre na entrecasca e na polpa das raízes}

O descritor 35, ácido cianídrico livre na entrecasca (casca primária, córtex) das raízes, apresentou média de 11,961, mínimo de 3,990 (DG-68, Reg.1), máximo de 31,777 (DG-116, Reg. 2) e amplitude de 27,387 (Tabela 4.2). As diferenças entre as etnovariedades foram significativas. $\mathrm{O}$ coeficiente de variação ambiental $\left(\mathrm{CV}_{\mathrm{e}}\right)$ foi médio, 13,23\% (Tabela 5.3). A diferença mínima significativa entre as médias pelo teste de Tukey foi de 5,385 (Tabela 25). Os parâmetros genéticos estimados (Tabela 6) foram de $98,54 \%$ para herdabilidade no sentido amplo ao nivel de médias $\left(\hat{h}_{m}^{2}\right), 95,77 \%$ para herdabilidade no sentido amplo ao nível de parcelas $\left(\hat{h}_{p}^{2}\right), 62,93 \%$ para o coeficiente de variação genética $\left(\mathrm{CV}_{\mathrm{g}}\right)$ e 4,75 para razão coeficiente de variação genética e coeficiente de variação ambiental $\left(\mathrm{CV}_{\mathrm{g}} / \mathrm{CV}_{\mathrm{e}}\right)$.

O descritor 37 , ácido cianídrico livre na polpa (parênquima) das raízes, apresentou média de 2,998, mínimo de 0,913 (DG-61, Reg.1), máximo de 7,807 (DG-44, Reg. 1) e amplitude de 6,894 (Tabela 4.3). As diferenças entre as etnovariedades foram significativas. $\mathrm{O}$ coeficiente de variação ambiental $\left(\mathrm{CV}_{\mathrm{e}}\right)$ foi alto, $27,08 \%$ (Tabela 5.3). A diferença mínima significativa entre as médias pelo teste de Tukey a $5 \%\left(\Delta_{5 \%}\right)$ de probabilidade foi de 2,7636 (Tabela 27).Os parâmetros genéticos estimados (Tabela 6) 
foram de $91,87 \%$ para herdabilidade no sentido amplo ao nivel de médias $\left(\hat{h}_{m}^{2}\right), 79,04 \%$ para a herdabilidade no sentido amplo ao nivel de parcelas $\left(\hat{h}_{p}^{2}\right), 52,59 \%$ para o coeficiente de variação genética $\left(\mathrm{CV}_{\mathrm{g}}\right)$ e de 1,94 para razão coeficiente de variação genética e coeficiente de variação ambiental $\left(\mathrm{CV}_{\mathrm{g}} / \mathrm{CV}_{\mathrm{e}}\right)$.

No geral, os teores de ácido cianídrico livre na entrecasca e na polpa das raizes foram baixos (Tabelas 25 e 27). Na média, a relação do teor livre sobre o potencial na entrecasca foi de $9,40 \%$, com minimo de $7,41 \%$ (DG59, Reg. 1) e máximo de $11,75 \%$ (DG128, Reg. 3). Para a polpa, a relação livre sobre potencial foi de $9,70 \%$ para média com mínimo de 6,42\% (DG132, Reg 3) e máximo 13,89\% (MANT, IAC), o que significa que apenas ao redor de $10 \%$ do potencial cianidrico está no forma livre e o restante na forma dos glicosídios cianogènicos.

Comparando com a relação livre sobre potencial nas folhas, que apresentou média de $17,44 \%$, mínimo de $5,63 \%$ e máximo de $35,20 \%$, as relações na entrecasca e polpa das raizes foram baixas, e com menor variação.

Não há também nenhuma relação entre o uso da mandioca pelas populações tradicionais e o teor de ácido cianídrico livre (Tabelas 25 e 26). Também as diferenças entre as médias regionais para as características não foram claras

As estimativas dos parâmetros genéticos foram altas para ambos os descritores, o que demonstra a predominância da variância genética na variância fenotípica e alta variabilidade genética para ambas caracteristicas.

\subsubsection{Relação com a domesticação da mandioca do potencial cianogênico nas raízes}

No processo da domesticação o comportamento do potencial cianogênico das raizes da mandioca não é conhecido. É provável que não houve sentido na seleção do caráter na domesticação, isto deve-se em parte devido a dificuldade das populações 
tradicionais identificarem este caráter como demonstrado pela ausência da relação entre uso e o potencial cianogênico, e de outra ao surgimento de técnicas de processamento que permitiram a redução do potencial cianogênico nos produtos da mandioca.

O processamento é um dos fatos mais interessantes na história da domesticação da mandioca e algumas questões estão em aberto: O processamento surgiu antes do início do plantio da mandioca, utilizando como matéria prima espécies silvestres? Porque os povos indígenas optaram por formas elaboradas de processamento como a farinha e o beiju à formas simples como o cozimento? A opção por processos mais elaborados é devido a maior eficiência destes na redução do potencial cianídrico?

A provável ausência de direção no processo da domesticação da mandioca, do caráter potencial cianogênico, não pode ser atribuida a limitações genéticas. Os parâmetros genéticos estimados, ressalvando-se o fato que foram determinados para o conjunto total de etnovariedades, apresentaram variabilidade e herança comparáveis e as vezes até superiores a outros caracteres que foram alterados na domesticação (Tabela 6).

\subsubsection{Caracterização química: folhas}

\subsubsection{Matéria seca nas folhas, em \%}

O descritor 22, porcentagem de matéria seca nas folhas, apresentou média 24,401, mínimo de 18,660, máximo de 28,667 e amplitude de 10,007 (Tabela 4.1). As diferenças entre as etnovariedades não foram significativas, o coeficiente de variação ambiental $\left(\mathrm{CV}_{\mathrm{e}}\right)$, de $14,38 \%$, foi médio (Tabela 5.1). Os parâmetros genéticos estimados (Tabela 6) foram de 30,15\% para herdabilidade no sentido amplo ao nível de médias $\left(\hat{h}_{m}^{2}\right), 12,58$ para herdabilidade no sentido amplo ao nivel de parcelas $\left(\hat{h}_{p}^{2}\right), 5,45 \%$ para o coeficiente de variação genética $\left(\mathrm{CV}_{\mathrm{g}}\right)$ e de 0,37 para razão coeficiente de variação genética e coeficiente de variação ambiental $\left(\mathrm{CV}_{\mathrm{g}} / \mathrm{CV}_{\mathrm{e}}\right)$ 
Embora este descritor não tenha apresentado significância ao nível geral, apresentou significância no desdobramento etnovariedades dentro de roças dentro de regiões (Tabela 5.1). Maiores detalhes dos desdobramentos serão discutidos mais adiante. A variação demonstrada pelo caráter é mais de natureza ambiental do que genética, e a variabilidade genética é muito baixa, característica comum demonstrada em todos os teores de umidade ou matéria seca aqui determinados.

\subsubsection{Teor de proteínas nas folhas, em \% da matéria seca}

O descritor 23, teor de proteína nas folhas, apresentou média de 24,401 , mínimo de 18,660 (DG-49, Reg. 1), máximo de 28,667 (DG-44, Reg. 1) e amplitude de 10,007 (Tabela 4.1). As diferenças entre as etnovariedades foram significativas, o coeficiente de variação ambiental $\left(\mathrm{CV}_{\mathrm{e}}\right)$, de $8,48 \%$, foi baixo (Tabela 5.2). A diferença mínima significativa entre as médias pelo teste de Tukey a $5 \%\left(\Delta_{5 \%}\right)$ de probabilidade foi de 7,039 (Tabela 14). Os parâmetros genéticos estimados (Tabela 6) foram de 54,28\% para herdabilidade no sentido amplo ao nível de médias $\left(\hat{h}_{m}^{2}\right), 28,36 \%$ para a herdabilidade no sentido amplo ao nível de parcelas $\left(\hat{h}_{p}^{2}\right), 5,33 \%$ para o coeficiente de variação genética $\left(\mathrm{CV}_{\mathrm{g}}\right)$ e de 0,62 para razão coeficiente de variação genética e coeficiente de variação ambiental $\left(\mathrm{CV}_{\mathrm{g}} / \mathrm{CV}_{\mathrm{e}}\right)$.

$\mathrm{O}$ teor de proteína foi o componente mais expressivo da matéria seca das folhas (Tabela 46), na massa úmida a média representou cerca de $8,25 \%$. Os dados obtidos confirmam que as folhas da mandioca apresentam alto teor de proteína e que esta característica está distribuída no germoplasma da espécie cultivada.

$\mathrm{O}$ valor nutritivo da folha da mandioca é ainda discutivel. A qualidade e a digestibilidade das proteínas e a presença de elementos antinutricionais são questões ainda controversas (Cereda, 1996, Bokanga, 1994b). De qualquer forma devido ao grande consumo de folhas em alguns países africanos, a mandioca passou a apresentar 
interesse não apenas pelo potencial de produção de amido nas raizes, mas também pelo potencial de produção de proteina nas folhas.

Entre as regiões houve equivalência entre as médias (Tabela 4.1). Embora o efeito de etnovariedades tenha sido significativo, a variabilidade genética expressa pelo caráter foi baixa e a variância ambiental foi preponderante na variação fenotípica. $\mathrm{O}$ teor de proteina nas folhas foi o descritor com menor variabilidade genética dos componentes da matéria seca das folhas, sendo que este também apresentou menor variabilidade genética quando comparado aos teores no caule e nas raizes.

\subsubsection{Teor matéria graxa nas folhas, em $\%$ da matéria seca}

O descritor 24, teor de matéria graxa nas folhas, apresentou média de 6,699, mínimo de 4,870 (DG-131, Reg. 3), máximo de 10,367 (DG-112, Reg. 2) e amplitude de 5,497 (Tabela 4.2). As diferenças entre as etnovariedades foram significativas, o coeficiente de variação ambiental $\left(\mathrm{CV}_{\mathrm{e}}\right)$, de 15,60\%, foi médio (Tabela 5.2). A diferença minima significativa entre as médias pelo teste de Tukey a $5 \%\left(\Delta_{5 \%}\right)$ de probabilidade foi de 3,5572 (Tabela 15). Os parâmetros genéticos estimados (Tabela 6) foram de $72,49 \%$ para herdabilidade no sentido amplo ao nível de médias $\left(\hat{h}_{m}^{2}\right), 46,76 \%$ para a herdabilidade no sentido amplo ao nivel de parcelas $\left(\hat{h}_{p}^{2}\right), 14,62 \%$ para o coeficiente de variação genética $\left(\mathrm{CV}_{\mathrm{g}}\right)$ e de 0,93 para razão coeficiente de variação genética e coeficiente de variação ambiental $\left(\mathrm{CV}_{\mathrm{g}} / \mathrm{CV}_{\mathrm{e}}\right)$

O teor de matéria graxa nas folhas, junto com o teor de cinzas, representaram os menores componentes da matéria seca das folhas (Tabela 46) . A variabilidade genética do descritor não foi alta, mas se comparada ao teor de proteina nas folhas foi bem superior, neste caso ao nivel de parcelas a variância genética representou $46,76 \%$ da variância fenotípica e o desvio padrão genético foi quase da mesma magnitude do desvio padrão ambiental. Houve equivalência entre as médias das regiões 1,2 , e 3 . 


\subsubsection{Teor de cinzas nas folhas, em \% da matéria seca}

O descritor 25, teor de cinzas nas folhas, apresentou média de 7,417, mínimo de 5,370 (DG-116, Reg. 2), máximo de 10,873 (DG-130, Reg. 3) e amplitude de 5,503 (Tabela 4.2). As diferenças entre as etnovariedades foram significativas, o coeficiente de variação ambiental $\left(\mathrm{CV}_{\mathrm{e}}\right)$, de $12,71 \%$, foi médio (Tabela 5.2). A diferença minima significativa entre as médias pelo teste de Tukey a $5 \%\left(\Delta_{5 \%}\right)$ de probabilidade foi de 3,209 (Tabela 16). Os parâmetros genéticos estimados (Tabela 6) foram de 77,30\% para herdabilidade no sentido amplo ao nivel de médias $\left(\hat{h}_{m}^{2}\right), 53,17 \%$ para a herdabilidade no sentido amplo ao nivel de parcelas $\left(\hat{h}_{p}^{2}\right), 13,54 \%$ para o coeficiente de variação genética $\left(\mathrm{CV}_{\mathrm{g}}\right)$ e de 1,06 para razão coeficiente de variação genética e coeficiente de variação ambiental $\left(\mathrm{CV}_{\mathrm{g}} / \mathrm{CV}_{\mathrm{e}}\right)$

A média, o mínimo e o máximo, e os parâmetros genéticos determinados pelo descritor teor de cinzas, foram parecidos aos determinados pelo teor de matéria graxa, entretanto a correlação genética entre elas não foi alta, como será visto mais adiante.

O teor de cinzas nas folhas apresentou menor variabilidade genética quando comparado aos teores de cinzas no caule e nas raizes. Ao nivel de parcelas, a variância genética representou $53,17 \%$ da variância fenotípica, o desvio padrão genético foi praticamente igual ao desvio padrão ambiental e a variabilidade genética em relação a média foi baixa.

As médias das regiões 1,2 e 3 foram equivalentes.

\subsubsection{Teor de fibras nas folhas, em \% da matéria seca}

O descritor 26, teor de fibras nas folhas, apresentou média de 17,875, mínimo de 14,340 (DG-41, Reg. 1), máximo de 23,103 (DG-117, Reg. 2) e amplitude de 
8,763 (Tabela 4.2). As diferenças entre as etnovariedades foram significativas, o coeficiente de variação ambiental $\left(\mathrm{CV}_{\mathrm{e}}\right)$, de $5,28 \%$, foi baixo (Tabela 5.2). A diferença mínima significativa entre as médias pelo teste de Tukey a $5 \%\left(\Delta_{5 \%}\right)$ de probabilidade foi de 3,210 (Tabela 17). Os parâmetros genéticos estimados (Tabela 6) foram de 87,66\% para herdabilidade no sentido amplo ao nível de médias $\left(\hat{h}_{m}^{2}\right), 70,31 \%$ para a herdabilidade no sentido amplo ao nivel de parcelas $\left(\hat{h}_{p}^{2}\right), 8,12 \%$ para o coeficiente de variação genética $\left(\mathrm{CV}_{\mathrm{g}}\right)$ e de 1,53 para razão coeficiente de variação genética e coeficiente de variação ambiental $\left(\mathrm{CV}_{\mathrm{g}} / \mathrm{CV}_{\mathrm{e}}\right)$

O teor de fibras nas folhas, conjuntamente com o teores de proteinas e de carboidratos, foram os componentes químicos mais significativos das folhas (Tabela 46).

Comparando com os outros caracteres das folhas, $\hat{h}_{m}^{2}$ e $\hat{h}_{p}^{2}$ foram superiores neste caso. O desvio padrão genético foi 1,53 vezes superior ao desvio padrão ambiental e a variância genética foi preponderante na variância fenotípica. Já a variabilidade genética em relação a média, expressa pela $\mathrm{CV}_{\mathrm{g}}$, foi baixa.

As médias do teor de fibras entre as regiões foram equivalentes.

\subsubsection{Teor de carboidratos nas folhas, em \% da matéria seca}

O descritor 27, teor de carboidratos nas folhas, apresentou média de 15,762, mínimo de 7,193, máximo de 21,957 e amplitude de 14,764. Devido a perda de algumas parcelas não foi realizada a análise de variância deste descritor. 


\subsubsection{Relação com a domesticação da mandioca dos componentes químicos das folhas}

$\mathrm{Na}$ realidade não se conhece o comportamento dos componentes químicos das folhas na domesticação. A comparação entre algumas espécies selvagens do gênero Manihot, Mill com o cultígeno seria muito interessante. Provavelmente, a não ser por ligação com outros caracteres do caule ou da raiz, não houve sentido na seleção destes caracteres na domesticação, já que as folhas não eram utilizadas pelas populações tradicionais autóctones das américas. Conforme Albuquerque \& Cardoso, 1980, a maniçoba é prato que apresenta influência africana, não sendo encontrado no regime alimentar indígena.

\subsubsection{Características químicas: Caule}

\subsubsection{Teor de umidade no caule, em \%}

O descritor 28, teor de umidade no caule, apresentou média de 64,046, mínimo de 55,247 (DG-123, Reg. 2), máximo de 72,327 (DG-133, Reg. 3) e amplitude de 18,080 (Tabela 4.2). As diferenças entre as etnovariedades foram significativas, o coeficiente de variação ambiental $\left(\mathrm{CV}_{\mathrm{e}}\right)$, de 6,89\%, foi baixo (Tabela 5.2). A diferença mínima significativa entre as médias pelo teste de Tukey a $5 \%\left(\Delta_{5 \%}\right)$ de probabilidade foi de 15,012 (Tabela 18). Os parâmetros genéticos estimados (Tabela 6) foram de 57,16\% para herdabilidade no sentido amplo ao nível de médias $\left(\hat{h}_{m}^{2}\right), 30,78 \%$ para a herdabilidade no sentido amplo ao nível de parcelas $\left(\hat{h}_{p}^{2}\right), 4,59 \%$ para o coeficiente de variação genética $\left(\mathrm{CV}_{\mathrm{g}}\right)$ e de 0,66 para razão coeficiente de variação genética e coeficiente de variação ambiental $\left(\mathrm{CV}_{\mathrm{g}} / \mathrm{CV}_{\mathrm{e}}\right)$. 
Embora as diferenças entre as etnovariedades tenham sido significativas pelo teste $F$, a variabilidade genética representada no conjunto das etnovariedades avaliadas foi baixa, o desvio padrão genético representou apenas $4,59 \%$ da média e o desvio padrão ambiental foi cerca de 1,5 vezes superior ao desvio padrão genético. No geral os teores de umidade ou matéria seca das folhas, caule e raizes apresentaram baixa variabilidade genética (Tabela 6).

\subsubsection{Teor de cinzas no caule, em \% da matéria seca}

O descritor 29, teor de cinzas no caule, apresentou média de 5,096, mínimo de 2,793 (DG-111, Reg. 2), máximo de 8,497 (DG-38, Reg. 1) e amplitude de 5,704 (Tabela 4.2). As diferenças entre as etnovariedades foram significativas, o coeficiente de variação ambiental $\left(\mathrm{CV}_{\mathrm{e}}\right)$, de $6,02 \%$, foi baixo (Tabela 5.2). A diferença mínima significativa entre as médias pelo teste de Tukey a $5 \%\left(\Delta_{5 \%}\right)$ de probabilidade foi de 1,044 (Tabela 19). Os parâmetros genéticos estimados (Tabela 6) foram de 97,83\% para herdabilidade no sentido amplo ao nivel de médias $\left(\hat{h}_{m}^{2}\right), 93,77 \%$ para a herdabilidade no sentido amplo ao nível de parcelas $\left(\hat{h}_{p}^{2}\right), 23,36 \%$ para o coeficiente de variação genética $\left(\mathrm{CV}_{\mathrm{g}}\right)$ e de 3,88 para razão coeficiente de variação genética e coeficiente de variação ambiental $\left(\mathrm{CV}_{\mathrm{g}} / \mathrm{CV}_{\mathrm{e}}\right)$

O teor de cinzas, conjuntamente com o teor de proteínas, foi o terceiro componente em importância quantitativa da matéria seca do caule (Tabela 46)

O teor de cinzas no caule apresentou também variabilidade genética considerável, a variância genética representou $93,77 \%$ da variância fenotípica ao nível de parcelas, o desvio padrão genético representou $23,36 \%$ da média e foi 3,88 vezes superior ao desvio padrão ambiental. O poder de discriminação do caráter foi grande, evidenciado pela magnitude dos parâmetros genéticos estimados e também pelo número 
de classes do teste de Tukey (Tabela 19), o que faz deste caráter um bom descritor para germoplasma da mandioca.

Não houve diferenças entre as médias das regiões para o caráter (Tabela 4.2).

\subsubsection{Teor de proteínas no caule, em \% da matéria seca}

O descritor 30, teor de proteinas no caule, apresentou média de 5,068, mínimo de 1,863 (DG-111, Reg. 2), máximo de 8,760 (DG-122, Reg. 2) e amplitude de 6,897 (Tabela 4.2). As diferenças entre as etnovariedades foram significativas, o coeficiente de variação ambiental $\left(\mathrm{CV}_{\mathrm{e}}\right)$, de 5,42\%, foi baixo (Tabela 5.2). A diferença mínima significativa entre as médias pelo teste de Tukey a $5 \%\left(\Delta_{5 \%}\right)$ de probabilidade foi de 0,936 (Tabela 20). Os parâmetros genéticos estimados (Tabela 6) foram de 98,80\% para herdabilidade no sentido amplo ao nível de médias $\left(\hat{h}_{m}^{2}\right), 96,51 \%$ para a herdabilidade no sentido amplo ao nivel de parcelas $\left(\hat{h}_{p}^{2}\right), 28,49 \%$ para o coeficiente de variação genética $\left(\mathrm{CV}_{\mathrm{g}}\right)$ e de 5,25 para razão coeficiente de variação genética e coeficiente de variação ambiental $\left(\mathrm{CV}_{\mathrm{g}} / \mathrm{CV}_{\mathrm{e}}\right)$.

A importância relativa do teor de proteínas do caule foi equivalente ao teor de cinzas com média um pouco superior a $5 \%$ da matéria seca (Tabela 46). Em termos dos componentes químicos do caule, o teor de proteínas apresentou a maior variabilidade genética demonstrada conjuntamente pelos parâmetros $\hat{h}_{p}^{2}$ e $\mathrm{CV}_{\mathrm{g}}$ A variância genética representou $96,51 \%$ da variância fenotípica ao nível de parcelas e o desvio padrão genético representou $28,49 \%$ da média. O desvio padrão genético foi também 5,25 vezes superior ao desvio padrão ambiental. Assim como o teor de cinzas do caule, o teor de proteína também constitui-se em um ótimo descritor de germoplasma da mandioca. 
A região 3 apresentou maior média com 6,030, seguida da região $1 \mathrm{com}$ 4,982 e da região 2 com 4,800 (Tabela 4.2), no entanto o efeito de regiões para este caráter não foi significativo pelo teste $\mathrm{F}$ (Tabela 5.2). 


\subsubsection{Teor de fibras no caule, em \% da matéria seca}

O descritor 31, teor de fibras no caule, apresentou média de 53,331, minimo de 43,730 (DG-45, Reg. 1), máximo de 62,880 (DG-111, Reg. 2) e amplitude de 19,150 (Tabela 4.2). As diferenças entre as etnovariedades foram significativas, o coeficiente de variação ambiental $\left(\mathrm{CV}_{\mathrm{e}}\right)$, de $1,23 \%$, foi baixo (Tabela 5.2). A diferença mínima significativa entre as médias pelo teste de Tukey a $5 \%\left(\Delta_{50^{\circ}}\right)$ de probabilidade foi de 2,237 (Tabela 21). Os paràmetros genéticos estimados (Tabela 6) foram de $98,86 \%$ para herdabilidade no sentido amplo ao nivel de médias $\left(\hat{h}_{m}^{2}\right), 96,66 \%$ para a herdabilidade no sentido amplo ao nivel de parcelas $\left(\hat{h}_{p}^{2}\right), 6,63 \%$ para o coeficiente de variação genética $\left(\mathrm{CV}_{\mathrm{g}}\right)$ e de 5,37 para razão coeficiente de variação genética e coeficiente de variação ambiental $\left(\mathrm{CV}_{\mathrm{g}} / \mathrm{CV}_{\mathrm{e}}\right)$

O teor de fibras foi o caráter de maior participação relativa na matéria seca do caule, com média de $53,33 \%$ (Tabela 46 ). A herdabilidade do teor de fibras foi muito alta, a variância genética representou $96,66 \%$ da variância fenotípica ao nível de médias e o desvio padrão genético foi 5,37 vezes superior ao desvio padrão ambiental. $\mathrm{O} \mathrm{CV}_{\mathbf{g}}$ foi baixo, o que significa que o desvio padrão genético foi pequeno em relação a média, portanto a variabilidade genética em relação a média não foi alta.

Não houve diferenças entre as médias das regiões para o caráter (Tabela $4.2)$.

\subsubsection{Teor de matéria graxa no caule, em \% da matéria seca}

O descritor 32, teor de matéria graxa no caule, apresentou média de 1,498, minimo de 0,607 (DG-111, Reg. 2), máximo de 1,970 (DG-121, Reg. 2) e amplitude de 1,363 (Tabela 4.2). As diferenças entre as etnovariedades foram significativas, o 
coeficiente de variação ambiental $\left(\mathrm{CV}_{\mathrm{e}}\right)$, de $12,01 \%$, foi médio (Tabela 5.3). A diferença minima significativa entre as médias pelo teste de Tukey a $5 \%\left(\Delta_{5 \%}\right)$ de probabilidade foi de 0,612 (Tabela 22). Os paràmetros genéticos estimados (Tabela 6) foram de $89,11 \%$ para herdabilidade no sentido amplo ao nível de médias $\left(\hat{h}_{m}^{2}\right), 73,18 \%$ para a herdabilidade no sentido amplo ao nível de parcelas $\left(\hat{h}_{p}^{2}\right), 19,83 \%$ para o coeficiente de variação genética $\left(C_{\mathrm{g}}\right)$ e de 1,65 para razão coeficiente de variação genética e coeficiente de variação ambiental $\left(\mathrm{CV}_{\mathrm{g}} / \mathrm{CV}_{\mathrm{e}}\right)$

O teor de matéria graxa foi o caráter de menor participação relativa na matéria seca do caule, com média aproximada de 1,50\% (Tabela 46). A herdabilidade do teor de matéria graxa foi alta, mas inferior se comparada aos teores de cinzas, proteína e fibras do caule. A variância genética representou $73,18 \%$ da variância fenotípica ao nivel de parcelas e o desvio padrão genético foi 1,65 vezes superior ao desvio padrão ambiental.

Ao contrário do descritor anterior, a variabilidade genética em relação a média do teor de matéria graxa não foi baixa, o desvio padrão genético representou quase $20 \%$ da média.

Não houve diferenças entre as médias das regiões para o caráter (Tabela $4.2)$.

\subsubsection{Teor de carboidratos totais no caule, em \% da matéria seca}

O descritor 33, teor de carboidratos totais no caule, apresentou média de 32,284, mínimo de 26,917 (DG-122, Reg. 2), máximo de 37,873 (DG-134, Reg. 3) e amplitude de 10,956 (Tabela 4.2). As diferenças entre as etnovariedades foram significativas, o coeficiente de variação ambiental $\left(\mathrm{CV}_{\mathrm{e}}\right)$, de $7,39 \%$, foi baixo (Tabela 5.3). A diferença mínima significativa entre as médias pelo teste de Tukey a $5 \%\left(\Delta_{5 \%}\right)$ de probabilidade foi de 8,123 (Tabela 23). Os parâmetros genéticos estimados (Tabela 6) foram de $67,25 \%$ para herdabilidade no sentido amplo ao nível de médias $\left(\hat{h}_{m}^{2}\right), 40,64 \%$ 
para a herdabilidade no sentido amplo ao nivel de parcelas $\left(\hat{h}_{p}^{2}\right), 6,11 \%$ para o coeficiente de variação genética $\left(\mathrm{CV}_{\mathrm{g}}\right)$ e de 0,82 para razão coeficiente de variação genética e coeficiente de variação ambiental $\left(\mathrm{CV}_{\mathrm{g}} / \mathrm{CV}_{\mathrm{e}}\right)$

O teor de carboidratos foi o segundo caráter em importância relativa da matéria seca do caule, com participação média de 32,28\%, inferior apenas ao teor de fibras (Tabela 46). O teor de carboidratos do caule é muito importante, como reserva de energia, para a rebrota da mandioca após o periodo de repouso nas regiões com estação fria definida e também como fonte de energia para brotação das estacas após o plantio. Neste caso, para uma melhor análise faltou decompor o teor de carboidratos na fração amido e na fração carboidratos solúveis.

Curiosamente, a etnovariedade que mais nos apresentou problemas na brotação das manivas para plantio foi justamente a DG-122 (mínimo de distribuição).

A herdabilidade do teor de carboidratos foi a mais baixa se comparada aos outros componentes da matéria seca do caule. A variância genética representou 40,64\% da variância fenotípica e o desvio padrão ambiental foi 1,22 vezes superior ao desvio padrão genético. A variabilidade genética expressada pelo $\mathrm{CV}_{\mathrm{g}}$ foi baixa, o desvio padrão genético representou apenas $6,11 \%$ da média.

Não houve diferenças entre as médias das regiões para o caráter.

\subsubsection{Relação com a domesticação da mandioca dos componentes químicos do caule}

O comportamento dos componentes químicos do caule na domesticação não é conhecido. No entanto, é provável que o teor de carboidratos no caule tenha sido favorecido devido a sua importância como fonte de energia para a brotação das estacas na propagação vegetativa. Nota-se que no gênero Manihot, Mill, a eficiência na propagação vegetativa é característica do cultígeno, sendo esta provavelmente alterada na domesticação. 


\subsubsection{Características químicas: Raiz}

\subsubsection{Teores de umidade nas raizes, em \%}

O descritor 46 , refere-se ao teor de umidade total da raiz (raiz sem periderme), o descritor 38 , ao teor de umidade da entrecasca da raiz e o descritor 39 , ao teor de umidade na polpa da raiz. A seguir os três descritores serão discutidos conjuntamente.

Os descritores 38,39 e 46 apresentaram respectivamente médias de 61,34, 61,65 e 62,52 mínimo de 55,37 (DG-60, Reg. 1), 51,48 (DG-124, Reg. 2) e 53,39 (DG124, Reg. 2) máximo de 69,79 (DG-45, Reg. 1), 75,29 (DG-71, Reg. 1) e 76,13 (DG-54, Reg. 1) e amplitude de $14,42,23,81$ e 22,74 (Tabela 4.3). Os três descritores apresentaram significância, o coeficiente de variação ambiental foi baixo nos três casos (Tabelas 5.3 e 5.4). As diferenças minimas significativas pelo teste de Tukey a $5 \%$ de probabilidade para os descritores 38,39 e 46 foram respectivamente $14,07,12,142$ e 11,858 (Tabelas 28,29 e 36).

Os parâmetros genéticos estimados para os descritores 38, 39 e 46 foram respectivamente (Tabela 6 ) $57,74 \%, 83,5 \%$ e $81,23 \%$ para a herdabilidade no sentido amplo ao nivel de médias $\left(\hat{h}_{m}^{2}\right) ; 31,3 \%, 62,8 \%$ e $59,06 \%$ para a herdabilidade no sentido amplo ao nivel de parcelas $\left(\hat{h}_{p}^{2}\right) ; 4,54 \%, 7,51 \%$ e 6,69\% para o coeficiente de variação genética $\left(\mathrm{CV}_{\mathrm{g}}\right)$ e de $0,67,1,29$ e 1,20 para a razão coeficiente de variação genética e coeficiente de variação ambiental $\left(\mathrm{CV}_{\mathrm{g}} / \mathrm{CV}_{\mathrm{e}}\right)$.

A variabilidade genética em relação a média para os três caracteres foi baixa. Mas a variabilidade genética do teor de umidade da polpa foi claramente superior ao teor de umidade da entrecasca. Para o teor de umidade na polpa, a variância genética foi predominante na variância fenotípica ao nivel de parcelas. Para o teor de umidade na entrecasca, ao contrário, a variância ambiental foi predominante na variância fenotípica. 
A variabilidade e a herdabilidade apresentada pelo teor de umidade na polpa das raizes foi surpreendentemente alta, principalmente para caracteres que normalmente apresentam baixa variação como a umidade, o que demonstra outra fonte de variação que influencia na produtividade da matéria seca da mandioca. Por exemplo, a etnovariedade DG124 apresentou 49\% de matéria seca na polpa das raizes, já a etnovariedade DG71 apresentou apenas $25 \%$ de matéria seca.

Embora o teste de Tukey não tenha discriminado, observaram-se várias etnovariedades com teor de umidade na polpa inferior ao apresentado pela variedade padrão Mantiqueira (Tabela 29). Por exemplo, a diferença da Mantiqueira em relação ao mínimo distribuição (DG-124) foi superior a $10 \%$, o que pode representar uma fonte de variação importante ao melhoramento da mandioca.

Observa-se na Tabela 29 que as etnovariedades provenientes do litoral sul do Est. de São Paulo apresentaram distribuição deslocada no sentido da menor umidade da polpa e as etnovariedades provenientes da região do Rio Negro apresentaram distribuição deslocada no sentido da maior umidade da polpa. É dificil estabelecer correlação a este fato.

O descritor 46 variou em função dos descritores 38 e 39 , é claro que devido ao maior peso relativo do descritor 39 , o descritor 46 apresentou distribuição parecida ao descritor 39 .

\subsubsection{Teor de proteína nas raízes, em \% da matéria seca}

O descritor 40, teor de proteina nas raizes, apresentou média de 2,634, minimo de 1,260 (DG-61, Reg. 1), máximo de 5,307 (DG-71, Reg. 1) e amplitude de 4,047 (Tabela 4.3). As diferenças entre as etnovariedades foram significativas, 0 coeficiente de variação ambiental $\left(\mathrm{CV}_{\mathrm{e}}\right)$, de $3,52 \%$, foi baixo (Tabela 5.4). A diferença minima significativa entre as médias pelo teste de Tukey a $5 \%\left(\Delta_{5 \%}\right)$ de probabilidade foi 
de 0,3157 (Tabela 30). Os paràmetros genéticos estimados (Tabela 6) foram de 99,50\% para herdabilidade no sentido amplo ao nivel de médias $\left(\hat{h}_{m}^{2}\right), 98,51 \%$ para a herdabilidade no sentido amplo ao nivel de parcelas $\left(\hat{h}_{p}^{2}\right), 28,62 \%$ para o coeficiente de variação genética $\left(\mathrm{CV}_{\mathrm{g}}\right)$ e de 8,12 para razão coeficiente de variação genética e coeficiente de variação ambiental $\left(\mathrm{CV}_{\mathrm{g}} / \mathrm{CV}_{\mathrm{e}}\right)$.

Em termos relativos da composição da matéria seca das raizes, o teor de proteinas foi o terceiro componente em importância, com participação média de 2,63\% (Tabela 46).

A variabilidade genética, em relação a média, foi a mais alta dos componente químicos da raiz, o desvio padrão genético representou $28,62 \%$ da média. A herdabilidade ao nivel de parcelas de $98,51 \%$ foi a mais alta de todos os 31 descritores continuos avaliados, o que significa que variância genética representou $98,51 \%$ da variância fenotipica. Isto faz do teor de proteinas da raiz um ótimo descritor de germoplasma.

É interessante notar também a relação do teor de proteinas na raízes, folhas e caule. O teor médio de proteina nas folhas foi 9,28 vezes superior ao das raizes. O teor médio de proteina no caule foi 1,93 vezes superior ao das raizes.

As diferenças entre as médias das regiões 1, 2 e 3 foram pequenas (Tabela 4.3). A variedade padrão Mantiqueira apresentou teor de proteinas de $1,31 \%$, valor próximo ao mínimo da distribuição.

\subsubsection{Teor de amido (fécula) nas raízes, em \% da matéria seca}

O descritor 41 , teor de amido nas raizes, apresentou média de 88,123 , mínimo de 79,43 (DG-71, Reg. 1), máximo de 90,640 (DG-67, Reg. 1) e amplitude de 11,21 (Tabela 4.3). As diferenças entre as etnovariedades foram significativas, 0 coeficiente de variação ambiental $\left(\mathrm{CV}_{\mathrm{e}}\right)$, de $0,26 \%$, foi baixo (Tabela 5.4). A diferença 
minima significativa entre as médias pelo teste de Tukey a $5 \%\left(\Delta_{5 \%}\right)$ de probabilidade foi de 0,7884 (Tabela 31). Os parâmetros genéticos estimados (Tabela 6) foram de 99,44\% para herdabilidade no sentido amplo ao nível de médias $\left(\hat{h}_{m}^{2}\right), 98,35 \%$ para a herdabilidade no sentido amplo ao nivel de parcelas $\left(\hat{h}_{p}^{2}\right), 2,01 \%$ para o coeficiente de variação genética $\left(\mathrm{CV}_{\mathrm{g}}\right)$ e de 7,72 para razão coeficiente de variação genética e coeficiente de variação ambiental $\left(\mathrm{CV}_{\mathrm{g}} / \mathrm{CV}_{\mathrm{e}}\right)$.

$\mathrm{Na}$ matéria seca das raízes, o teor de amido foi o componente mais importante com participação média de $88,12 \%$. A média da distribuição ficou mais próxima do máximo de $90,64 \%$, do que do mínimo de $79,43 \%$ (Tabela 46 )

$A$ variabilidade genética do caráter em relação a média expressa pela $\mathrm{CV}_{\mathrm{g}}$ foi muito baixa, aliás, dos 31 caracteres avaliados foi a mais baixa com 2,01\% (Tabela 6), o que na prática restringe a possibilidade de aumento significativo do teor de amido através da seleção. Ao contrário, a herdabilidade do caráter foi muito alta, a variância genética representou $98,35 \%$ da variância fenotípica ao nivel de parcelas. De todos os 31 caracteres avaliados foi o terceiro com maior herdabilidade encontrada, atrás do teor de proteinas e do teor de fibras da raiz. O desvio padrão genético foi 7,72 vezes superior ao desvio padrão ambiental, o que significa que na realidade a variância ambiental apresentada foi muito baixa.

A variedade padrão Mantiqueira apresentou média de $89,40 \%$ de amido. Dez etnovariedades apresentaram teor superior ao padrão, entre as quais as etnovariedades DG67, DG118 e DG132 apresentaram teor significativamente superior pelo teste de Tukey (Tabela 31). Nota-se também na Tabela 7 que as etnovariedades DG132 e DG67 apresentaram também boa produção.

As diferenças entre as médias das regiões 1,2 e 3 foram pequenas. 


\subsubsection{Teor de matéria graxa nas raízes, em \% da matéria seca}

O descritor 42, teor de matéria graxa nas raizes, apresentou média de 0,846, mínimo de 0,657 (DG-114, Reg. 2), máximo de 0,993 (DG-130, Reg. 1) e amplitude de 0,336 (Tabela 4.3). As diferenças entre as etnovariedades foram significativas, o coeficiente de variação ambiental $\left(\mathrm{CV}_{\mathrm{e}}\right)$, de 7,39\%, foi baixo (Tabela 5.4). A diferença mínima significativa entre as médias pelo teste de Tukey a $5 \%\left(\Delta_{5 \%}\right)$ de probabilidade foi de 0,2128 (Tabela 32). Os parâmetros genéticos estimados (Tabela 6) foram de $77,30 \%$ para herdabilidade no sentido amplo ao nível de médias $\left(\hat{h}_{m}^{2}\right), 53,18 \%$ para a herdabilidade no sentido amplo ao nível de parcelas $\left(\hat{h}_{p}^{2}\right), 7,87 \%$ para o coeficiente de variação genética $\left(\mathrm{CV}_{\mathrm{g}}\right)$ e de 1,06 para razão coeficiente de variação genética e coeficiente de variação ambiental $\left(\mathrm{CV}_{\mathrm{g}} / \mathrm{CV}_{\mathrm{e}}\right)$.

Relativamente, o teor de matéria graxa com média de 0,85\% foi o componente químico de menor importância nas raizes (Tabela 46).

Em relação aos demais descritores, a herdabilidade apresentada não foi alta. Os valores encontrados para $\hat{h}_{m}^{2}$ e $\hat{h}_{p}^{2}$ foram os menores de todos os componentes da matéria seca das raizes, o desvio padrão genético foi apenas 1,06 vezes superior ao desvio padrão ambiental (Tabela 6). A variabilidade genética em relação a média também foi baixa.

Dentre os descritores da matéria seca das raizes, o teor de matéria graxa foi o que apresentou menor importância para descrição da variabilidade do material.

Não houve diferenças entre as médias das regiões para o caráter (Tabela 4.3). A variedade padrão Mantiqueira apresentou média $0,78 \%$. 


\subsubsection{Teor de cinzas nas raizes, em \% da matéria seca}

O descritor 43, teor de cinzas nas raizes, apresentou média de 2,372, mínimo de 1,327 (DG-111, Reg. 2), máximo de 4,733 (DG-71, Reg. 1) e amplitude de 3,407 (Tabela 4.3). As diferenças entre as etnovariedades foram significativas, o coeficiente de variação ambiental $\left(\mathrm{CV}_{\mathrm{e}}\right)$, de $4,46 \%$, foi baixo (Tabela 5.4). A diferença minima significativa entre as médias pelo teste de Tukey a $5 \%\left(\Delta_{5 \%}\right)$ de probabilidade foi de 0,3605 (Tabela 33). Os parâmetros genéticos estimados (Tabela 6) foram de 98,77\% para herdabilidade no sentido amplo ao nivel de médias $\left(\hat{h}_{m}^{2}\right), 96,41 \%$ para a herdabilidade no sentido amplo ao nivel de parcelas $\left(\hat{h}_{p}^{2}\right), 23,14 \%$ para o coeficiente de variação genética $\left(\mathrm{CV}_{\mathrm{g}}\right)$ e de 5,18 para razão coeficiente de variação genética e coeficiente de variação ambiental $\left(\mathrm{CV}_{\mathrm{g}} / \mathrm{CV}_{\mathrm{e}}\right)$.

Em termos relativos da composição da matéria seca das raizes o teor de cinzas foi o quarto em importância com média de 2,37\% (Tabela 46).

A herdabilidade apresentada pelo caráter foi alta, ao nivel de parcelas a variância genética representou $96,41 \%$ da variância fenotípica, o desvio padrão genético foi 5,18 vezes superior ao desvio padrão ambiental. $\mathrm{O} \mathrm{CV}_{\mathrm{g}}$ de $23,14 \%$ demonstra que a variabilidade genética em relação a média foi alta, dentre os componentes da matéria seca das raizes foi o segundo maior $\mathrm{CV}_{\mathrm{g}}$ (Tabela 6). Isto faz do teor de cinzas nas raizes um bom descritor de germoplasma de mandioca.

As diferenças entre as médias das regiões foram pequenas (Tabela 4.3). A variedade padrão Mantiqueira apresentou média de 2,20\% valor próximo a média da distribuição. 


\subsubsection{Teor de fibras nas raízes, em \% da matéria seca}

O descritor 44, teor de fibras nas raízes, apresentou média de 4,090, mínimo de 2,507 (DG-132, Reg. 3), máximo de 7,697 (DG-71, Reg. 1) e amplitude de 5,190 (Tabela 4.3). As diferenças entre as etnovariedades foram significativas, o coeficiente de variação ambiental $\left(\mathrm{CV}_{\mathrm{e}}\right)$, de 2,69\%, foi baixo (Tabela 5.4). A diferença mínima significativa entre as médias pelo teste de Tukey a $5 \%\left(\Delta_{5 \%}\right)$ de probabilidade foi de 0,3739 (Tabela 34). Os parâmetros genéticos estimados (Tabela 6) foram de 99,49\% para herdabilidade no sentido amplo ao nivel de médias $\left(\hat{h}_{m}^{2}\right), 98,48 \%$ para a herdabilidade no sentido amplo ao nivel de parcelas $\left(\hat{h}_{p}^{2}\right), 21,61 \%$ para o coeficiente de variação genética $\left(\mathrm{CV}_{\mathrm{g}}\right)$ e de 8,05 para razão coeficiente de variação genética e coeficiente de variação ambiental $\left(\mathrm{CV}_{\mathrm{g}} / \mathrm{CV}_{\mathrm{e}}\right)$.

Em termos relativos da composição da matéria seca das raízes o teor de fibras foi o segundo em importância com média de 4,09\% (Tabela 46).

A herdabilidade do caráter encontrada foi a segunda maior de todos os 31 descritores avaliados (Tabela 6). Ao nivel de parcelas a variância genética representou $98,48 \%$ da variância fenotipica e o desvio genético, foi 8,05 vezes superior ao desvio padrão residual, valores portanto muito altos. A variabilidade genética em relação a média também foi alta, mas inferior aos teores de proteína e cinzas nas raizes. Portanto, o teor de fibras pode ser considerado um ótimo descritor de germoplasma de mandioca.

A região 1 apresentou maior média com 4,21, seguido da região 2 com 4,12 e da região 3 com 3,36. Apesar da aparente concentração de etnovariedades, com maior teor de fibras nas regiões do Rio Negro e Solimões, observa-se na Tabela 5.4 que o efeito de regiões não apresentou significância pelo teste $F$. A variedade padrão Mantiqueira apresentou média de 4,37, superior a média geral da distribuição.

Um fato interessante foi a etnovariedade DG71 Anta, Região 1, que posicionou-se nos extremos da distribuição em 5 descritores. Ela apresentou o menor teor de matéria seca na polpa das raizes e o menor teor de amido dentre o conjunto total 
de etnovariedades avaliadas, com apenas $25 \%$ e $79,43 \%$ respectivamente. Apresentou também os maiores teores de fibras, proteína e cinza nas raizes, se comparada a todas etnovariedades avaliadas, com respectivamente $7,69 \%, 5,31 \%$ e $4,73 \%$.

\subsubsection{Teor de açúcar solúvel nas raízes, em \% da matéria seca}

O descritor 45, teor de açúcar solúvel nas raizes, apresentou média de 1,699, mínimo de 1,143 (DG-124, Reg. 2), máximo de 1,963 (DG-138, Reg. 2) e amplitude de 0,820 (Tabela 4.3). As diferenças entre as etnovariedades foram significativas, o coeficiente de variação ambiental $\left(\mathrm{CV}_{\mathrm{e}}\right)$, de 5,57\%, foi baixo (Tabela 5.4). A diferença minima significativa entre as médias pelo teste de Tukey a $5 \%\left(\Delta_{5 \%}\right)$ de probabilidade foi de 0,3849 (Tabela 35). Os parâmetros genéticos estimados (Tabela 6) foram de $85,95 \%$ para herdabilidade no sentido amplo ao nível de médias $\left(\hat{h}_{m}^{2}\right), 67,11 \%$ para a herdabilidade no sentido amplo ao nivel de parcelas $\left(\hat{h}_{p}^{2}\right), 9,50 \%$ para o coeficiente de variação genética $\left(\mathrm{CV}_{\mathrm{g}}\right)$ e de 1,42 para razão coeficiente de variação genética e coeficiente de variação ambiental $\left(\mathrm{CV}_{\mathrm{g}} / \mathrm{CV}_{\mathrm{e}}\right)$.

Em termos relativos da composição da matéria seca das raizes, o teor açúcar solúvel foi o penúltimo componente em importância, representando na média apenas $1,70 \%$ da matéria seca das raízes. O teor de açúcar solúvel representou também uma pequena fração do teor de carboidratos totais, que foi composto em mais $98 \%$ por amido (Tabela 46).

A herdabilidade não foi baixa, mas inferior a maioria dos componentes da matéria seca das raizes, com exceção do teor de matéria graxa. Ao nível de parcelas, a variância genética correspondeu a $67,11 \%$ da variância fenotípica e o desvio padrão genético, foi 1,42 vezes superior ao desvio padrão ambiental (Tabela 6). A variabilidade genética em relação a média expressa pela $\mathrm{CV}_{\mathrm{g}}$ de $9,50 \%$, foi de mediana a inferior, se comparada a variabilidade dos outros componentes da matéria seca das raizes. Se 
comparado ao teor de amido nas raizes, o teor de açúcar solúvel apresentou herdabilidade inferior e coeficiente de variação genética superior.

As diferenças entre as médias das regiões foram pequenas (Tabela 4.3). A variedade padrão Mantiqueira apresentou média de 1,83 valor eqüidistante entre a média geral e o máximo da distribuição (Tabela 35).

\subsubsection{Relação com a domesticação da mandioca dos componentes químicos da raiz}

$\mathrm{Na}$ domesticação da mandioca, o teor de amido foi claramente favorecido em relação aos demais componentes químicos da matéria seca das raizes. Aliás, a domesticação foi muito eficiente neste sentido, pois neste trabalho o teor de amido variou nas etnovariedades de 79,43\% a 90,64\% da matéria seca. Muitos pesquisadores apontam valores próximos a 90\%, como limite bioquímico para aumento do teor de amido nas raizes. O interessante é que os agricultores autóctones, com suas técnicas simples de melhoramento, conseguiram obter variedades com teor de amido próximo do limite máximo bioquímico.

\subsection{Associação genética dos descritores e domesticação}

Nas Tabelas 37.1 e 37.2 estão apresentadas as estimativas das correlações fenotipicas, para os descritores 15 a 46. Nas Tabelas 38.1 e 38.2 , as estimativas das correlações genéticas. Nas Tabelas 39.1 e 39.2, as estimativas das correlações ambientais.

Nas Tabelas $37.1,37.2,38.1$ e 38.2 , observa-se que as estimativas das correlações fenotípicas e genéticas foram próximas. A seguir, serão analisadas principalmente as correlações genéticas. Para as correlações, genética e ambiental, foi utilizado o critério, maior ou igual a 0,6, para alta correlação. Os pares que apresentaram alta correlação estão realçados em negrito nas Tabelas 38.1, 38.2, 39.1 e 39.2. 
O descritor 15 , peso de raízes, apresentou correlação genética alta e positiva com os descritores: peso da parte aérea $\left(\mathrm{I}_{G(15.16)}=0,75\right)$, indice de colheita $\left(r_{G(15,17)}=0,73\right)$, número de raízes $\left(r_{G(15,18)}=0,87\right)$ e produção de amido $\left(r_{G(15,19)}=0,99\right)$. Alta e negativa, com os descritores: umidade da polpa das raizes $\left(\mathrm{r}_{\mathrm{G}(15.39)}=-0,64\right)$ e umidade das raizes $\left(\mathrm{r}_{\mathrm{G}(15.46)}=-0,64\right)$.

É claro que na domesticação da mandioca o peso de raizes e o indice de colheita foram favorecidos. O comportamento do peso da parte aérea não é conhecido, mas provavelmente não foi favorecido.

A alta correlação genética encontrada para os pares, peso de raizes com peso da parte aérea, peso de raizes com índice de colheita, e a falta de correlação genética entre peso da parte aérea e índice de colheita, torna possivel a seleção conjunta para o aumento do peso de raizes e do índice de colheita, sem alterações expressivas no peso da parte aérea. Valle (1990) encontrou alta correlação genética entre o peso de raizes e o peso da parte aérea, em populações segregantes de mandioca, derivadas de cultivares comerciais.

Os descritores, peso de raízes e peso da parte aérea, também apresentaram alta correlação ambiental $\left(\mathrm{r}_{\mathrm{E}(15.16)}=0,73\right)$, o que significa que os fatores ambientais atuam no mesmo sentido.

A alta correlação genética entre peso e número de raizes, demonstra que os genótipos mais produtivos são os que apresentam maior número de raízes tuberosas.

Teoricamente, seria mais fácil aos agricultores autóctones, a seleção indireta para aumento do peso de raizes através do caráter número de raizes tuberosas. Infelizmente os caracteres utilizados pelos agricultores no melhoramento da produtividade e na domesticação da mandioca não são conhecidos.

O inconveniente na utilização do número de raizes tuberosas para aumento do peso de raizes, é a alta correlação positiva entre número de raizes e peso da parte aérea. Acosta-Espinoza (1984) também encontrou alta correlação entre os pares número de raízes, peso de raizes e número de raízes, peso da parte aérea. 
Um fato interessante foi a alta correlação genética negativa encontrada entre a umidade na polpa das raizes e o peso de raizes, o que significa que genótipos mais produtivos foram os que apresentaram maior teor de matéria seca na polpa das raizes. Sem dúvida a persistência desta correlação, a natureza genética da associação e as implicações evolutivas da associação devem ser melhor estudadas. Inclusive relacionando o armazenamento de água nas raizes com a adaptação a climas com precipitação irregular, o que poderia estar relacionado com os ancestrais do cultígeno e com a geografia da domesticação.

Muito importantes na domesticação da mandioca foram alterações na composição química das raizes.

Na domesticação da mandioca, o teor de amido nas raizes foi claramente favorecido em relação aos outros componentes químicos das raízes. Observa-se na Tabela 38.2 que o teor de amido apresentou correlação genética, alta e negativa, com os descritores umidade na polpa das raizes $\left(\mathrm{r}_{\mathrm{G}(41,39)}=-0,77\right)$, teor de proteina nas raizes $\left(\mathrm{r}_{\mathrm{G}(41,30)}=-0,73\right)$, teor de cinzas nas raizes $\left(\mathrm{r}_{\mathrm{G}(41,43)}=-0,85\right)$, teor de fibras nas raizes $\left(r_{G(41,44)}=-0,82\right)$ e teor de umidade nas raizes $\left(r_{G_{(41,46)}}=-0,77\right)$.

A relação do teor de amido com o teor de fibras nas raizes foi fundamental na domesticação, e hoje é uma das principais características que separam o cultígeno dos ancestrais selvagens. A alta correlação genética negativa apresentada entre o teor de amido e o teor de fibras e também a alta correlação negativa com outros dois importantes componentes da matéria seca, proteina e cinzas, de certa forma facilitou o sucesso dos agricultores autóctones na domesticação e melhoramento da mandioca, e certamente possibilitou a obtenção de etnovariedades com teor de amido variando de $80 \%$ a $90 \%$ da matéria seca das raizes.

A correlação genética, alta e negativa, entre o teor de amido e o teor de umidade na polpa das raizes $\left(\mathrm{r}_{\mathrm{G}(41.39)}=-0,77\right)$ e as correlações genéticas, altas e positivas, entre o teor de umidade na polpa e os teores de fibras $\left(\mathrm{r}_{\mathrm{G}(39.44)}=0,80\right)$ e de cinzas $\left(\mathrm{r}_{\mathrm{G}(39,43)}=0,66\right)$ nas raizes, reforçam a hipótese sugerida anteriormente de que a 
domesticação talvez tenha favorecido o teor de matéria seca nas raizes, e até talvez tenha alterado o ambiente da espécie.

$\mathrm{Na}$ domesticação a habilidade para propagação vegetativa também foi favorecida. Um dos fatores importantes na brotação das manivas é o armazenamento de energia na forma de carboidratos. No caule deve ter ocorrido o mesmo processo que ocorreu nas raizes, ou seja, o favorecimento do teor de carboidratos em detrimento principalmente do teor de fibras, só que em menor intensidade. A correlação genética, alta e negativa, encontrada entre o teor de carboidratos e o teor de fibras no caule $\left(r_{G(31,33)}=-0,66\right)$ facilitou este processo.

O processo genetico da domesticação seria ainda mais facilitado se houvessem associações genéticas que favorecessem ao mesmo tempo alterações no caule e nas raizes.

O teor de carboidratos no caule apresentou correlações genéticas negativas com os teores: de proteina nas raizes $\left(\mathrm{I}_{\mathrm{G}(33,40)}=-0,40\right)$, de matéria graxa nas raizes $\left(r_{G(33.42)}=-0,41\right)$, de cinzas nas raizes $\left(r_{G(33.43)}=-0,21\right)$ e de fibras nas raizes $\left(r_{G(33,44)}=-0,26\right)$. Apresentou também correlação genética positiva com o teor de amido no caule $\left(\mathrm{r}_{\mathrm{G}(33,41)}=-0,41\right)$. O sentido das associações favoreceram as mudanças em ambos os órgãos, mas as correlações genéticas não foram altas. Um erro neste caso, foi a não decomposição do teor de carboidratos na fração amido e na fração carboidratos solúveis, como decomposto nas raizes.

Uma curiosidade foi o comportamento dos descritores de ácido cianidrico na raiz. Apenas os componentes potencial e livre no mesmo tecido foram altamente correlacionados: o potencial cianogênico na entrecasca da raiz com o ácido cianidrico livre na entrecasca da raiz $\left(\mathrm{r}_{\mathrm{G}(34,35)}=0,99\right)$ e o potencial cianogênico na polpa da raiz com $\mathrm{o}$ ácido cianídrico livre na polpa da raiz $\left(\mathrm{r}_{\mathrm{G}(36,37)}=0,98\right)$. Isso que significa que os potenciais de ácido cianidrico na entrecasca e na polpa não são correlacionados. Também não há nenhuma correlação entre o peso de raizes e os teores de ácido cianidrico nas raizes. Isto reforça a hipótese de que na domesticação não houve sentido na seleção dos caracteres que expressam conteúdo de ácido cianídrico nas raizes. 
Devido à especificidade da dinâmica evolutiva de espécies com propagação vegetativa para cultivo, em que a recombinação não é obrigatória a cada novo ciclo (Cury, 1993; Martins, 1994b), a conjunção de associações genéticas favoráveis a domesticação é fundamental, pois o número de gerações de recombinação são bem inferiores, se comparadas, por exemplo, às plantas de cruzamento cultivadas através de sementes. Portanto a quebra de altas correlações genéticas são mais dificeis em populações desta natureza. De qualquer forma seria muito interessante a confirmação das correlações genéticas encontradas em populações segregantes.

\subsection{Distribuição da variabilidade genética com base na análise univariada dos descritores}

Os quadrados médios do desdobramento da análise de variância e as significâncias pelo teste $F$, estão representados nas Tabelas 5.1, 5.2, 5.3 e 5.4. Nota-se no desdobramento entre regiões (A), que apenas 5 entre os 31 descritores avaliados foram significativos.

Os descritores que apresentaram significância entre regiōes foram: 15 (peso de raizes), 16 (peso da parte aérea), 18 (número de raizes), 19 (produção de amido) e 28 (umidade do caule), sendo quatro descritores agronômicos e apenas 1 químico. Isso significa, que a variabilidade entre regiões, foi significativa para uma minoria de descritores e está concentrada nos descritores agronômicos.

No desdobramento entre roças dentro de regiões (R/A), apenas os descritores: 15 (peso de raízes), 19 (produção de amido), 37 (ácido cianídrico livre na polpa das raizes), 40 (teor de proteína nas raizes), 41 (teor de amido nas raizes) e 44 (teor de fibra nas raizes) apresentaram significância, isto é; apenas 6 entre os 31 descritores avaliados. Portanto, a variabilidade entre roças dentro de regiões, também foi significativa numa minoria de descritores e está concentrada nos descritores agronômicos e químicos das raizes. 
No desdobramento entre etnovariedades dentro de roças dentro de regiões (V/R/A), todos os descritores avaliados, com exceção do descritor 20 (potencial de ácido cianídrico nas folhas), apresentaram significância. Portanto, a variabilidade entre etnovariedades dentro de roças dentro de regiões ou simplesmente dentro das roças, foi significativa na quase totalidade dos descritores.

Também estão nas Tabelas 5.1, 5.2, 5.3 e 5.4, as significâncias pelo teste $\mathrm{F}$, dos quadrados médios para os desdobramentos complementares, desdobramentos estes para cada uma das regiões estudadas. Os resultados demonstram que os quadrados médios entre roças que apresentaram significância, estão praticamente confinados na região 1, bacia do Rio Negro, enquanto que a significância dos quadrados médios da variação dentro de roças, está distribuída nas três regiões estudadas.

Nas Tabelas 40.1, 40.2 e 40.3 estão as estimativas da variância genética para cada desdobramento. Os valores em negrito relacionam as estimativas das variâncias genéticas a significância dos quadrados médios, e significam que os quadrados médios correspondentes foram significativos a pelo menos $5 \%$ de probabilidade.

Observa-se que para os descritores agronômicos, a variância genética foi distribuida entre a componente entre regiões e a componente dentro de roças. Para os descritores quimicos das folhas, do caule e das raizes, a variabilidade genética, quase na sua totalidade, foi localizada dentro da roça ou dentro da população.

A distribuição da variância genética nas componentes: entre regiões $\left(\hat{\sigma}_{A}^{2}\right)$, entre roças dentro de regiões $\left(\hat{\sigma}_{R / A}^{2}\right)$ e entre etnovariedades dentro de roças dentro de regiões $\left(\sigma_{V^{\prime} / R / A}^{2}\right)$, pode ser mais facilmente interpretada quando observa-se a Tabela 41 , onde as variâncias genéticas foram distribuidas em porcentagem para cada desdobramento. Para a elaboração da Tabela 41, foram considerados os valores negativos como variância genética igual a zero. A transformação em porcentagem foi interessante pois permitiu a comparação da distribuição das variâncias genéticas de diferentes descritores.

Observa-se na Tabela 41, que dos 31 descritores avaliados, apenas os descritores 15 (peso de raizes) e 19 (peso de amido), apresentaram preponderância na 
variação genética total, da componente entre regiões $\left(\hat{\sigma}_{4}^{2}\right)$. Nos demais descritores, a preponderância foi da componente dentro de roças $\left(\sigma_{V / R / A}^{2}\right)$.

$\mathrm{Na}$ média, os descritores agronômicos apresentaram distribuição da variabilidade genética diferenciada em relação aos químicos. Observa-se para os agronômicos (Tabela 41), que $48,80 \%$ da variância genética total foi devido a componente entre regiões, $9,72 \%$ a componente entre roças dentro de regiões e $41,49 \%$ a componente dentro de roças. Portanto, a variância genética foi distribuída nas componentes entre regiões e dentro de roças.

Ainda na Tabela 41, observa-se a distribuição média da variância genética para os descritores quimicos das folhas, do caule e das raízes. A distribuição da variância genética foi muito parecida nos três órgãos, com predominância da componente da variância dentro de roças. Apenas para descritores químicos das raízes a componente entre roças dentro de regiões também foi significativa.

$\mathrm{Na}$ média de todos o 31 descritores avaliados, $76,13 \%$ da variância genética total foi devido à componente entre etnovariedades dentro de roças dentro de regiões (dentro de roças), 12,81\% a componente entre regiões e $11,05 \%$ a componente entre roças dentro de regiões (Tabela 41). Portanto na média geral $76,13 \%$ da variabilidade genética foi devida a variação dentro de roças.

A Tabela 42, demonstra como foi a distribuição em porcentagem, da variância genética dentro das roças $\left(\hat{\sigma}_{V / R / A}^{2}\right)$, para cada descritor e para cada região em particular estudada. Também estão apresentadas a média parcial para os descritores agronômicos, químicos das folhas, químicos do caule e químicos da raiz.

A distribuição da variância genética dentro de roças nas regiões, foi particular para cada descritor. Na média de todos os descritores, 36,73\% estava presente dentro das roças da região do Rio Negro, 36,24\% na região do Rio Solimões e 27,04\% na região do litoral sul de São Paulo. Portanto as regiões Amazônicas se eqüivaleram na distribuição da variabilidade genética dentro das roças, e a região paulista apresentou variabilidade inferior as demais regiões. 
Como demonstra Cury (1993), a população da espécie cultivada na roça é a população referencial, e na qual atuam os processos evolutivos. Portanto, a estimativa da variância genética entre etnovariedades dentro de roças dentro de regiões $\left(\hat{\sigma}_{V / R / A}^{2}\right)$ é a estimativa da variância genética dentro da população, e a estimativa da variância entre roças dentro de regiões $\left(\hat{\sigma}_{R / A}^{2}\right)$ é a estimativa da variância genética entre populações dentro de regiões.

A magnitude da concentração da variabilidade genética dentro das populações foi surpreendente, tratando-se das diversas origens e regiões de coleta do material estudado, como populações ao longo da bacia do Rio Negro, Rio Solimões e litoral sul do Estado de São Paulo. Isso coincide com a distribuição da variabilidade genética em populações naturais de plantas não endôgamas (Futuyma, 1993).

No aspecto evolutivo a consequêencia de tais resultados são que o fluxo genético entre as populações devem ser expressivos (Futuyma, 1993).

Como demonstra Cury (1993), é a migração que possibilita fluxo gênico entre diferentes populações na mandioca, tendo como principal ocorrência a troca ou introdução de cultivares devido a ação humana, já que a dispersão natural de sementes e a dispersão de gametas através do pólen parecem ter papel limitado no fluxo gênico interpopulacional da mandioca.

Chernela (1987) demonstra com detalhes a importância da troca de etnovariedades de mandioca na cultura de diversas tribos da familia Tukâno Oriental, habitantes do rio Uaupés, bacia do Rio Negro. De qualquer forma, não é fácil explicar o fluxo gênico entre populações do litoral paulista e da Amazônia. Isto pode estar relacionado ao movimento migratório de populações indígenas no passado remoto e também ao movimento migratório atual da população brasileira.

$\mathrm{Na}$ Tabela 43, estão distribuídos em porcentagem, a soma das variâncias genéticas entre roças e entre etnovariedades dentro de roças para cada região estudada. $\mathrm{Na}$ média de todos os descritores avaliados a região do Rio Negro apresentou maior parte da variabilidade genética com $40,24 \%$, seguida do Rio Solimões com $31,62 \%$ e do litoral sul do Estado de São Paulo com 28,14\%. 
A distribuição da variância genética para cada região, obedeceu a mesma seqüência do número de etnovariedades coletados em cada uma delas (Tabela 1), mas não foi proporcional. A região 3, litoral sul do Est. de São Paulo, apresentou 17\% das etnovariedades coletadas e $28 \%$ da variância genética, a região 2 , Rio Solimões, apresentou $28 \%$ das etnovariedades coletadas e $31 \%$ da variância genética e a região 1 , Rio Negro, apresentou $53 \%$ das etnovariedades coletadas e $40 \%$ da variância genética.

\subsection{Divergência genética multivariada}

\subsubsection{Divergência genética por variáveis canônicas}

$\mathrm{Na}$ Tabela 44, estão as estimativas dos autovalores da análise por variáveis canônicas. A variável canônica 1 (VC1) representou 33,23\% da variância total; a VC2, 24,66\%; a VC3, 11,79\% e a VC4, 9,44\%. Nota-se a relativa dispersão da variância, sendo que o patamar adequado de acúmulo, de $80 \%$ da variância, só foi ultrapassado com a variável canônica 5 (VC5).

Na figura 1 está a dispersão gráfica da variável canônica 1 versus variável canônica 2, onde foram plotadas as 56 etnovariedades através dos escores das variáveis canônicas. No geral, o padrão de dispersão foi contínuo, com duas etnovariedades distanciando-se das demais, DG71, Anta (Rio Negro) e DG122, Marreca de Semente (Rio Solimões), sendo que a periferia da distribuição, com exceção das etnovariedades DG138, DG122 e DG131, foi formada por etnovariedades provenientes da região do Rio Negro.

A DG71, foi a etnovariedade que mais se distanciou do centro da dispersão, confirmando a impressão deixada na distribuição univariada de vários descritores, em que este genótipo ocupou diversos extremos (ver item 4.1.6.6). A DG 71 é proveniente de uma roça (Panacarica) onde foram encontradas espécies de Manihot selvagem convivendo simpatricamente com o cultígeno (Martins, 1994). O padrão de 
dispersão da DG-71, sugere que ela possa ser produto da hibridação introgressiva entre o cultígeno e selvagens.

A DG122, que é um recombinante originário de semente (Tabela 1), também não aproximou-se de nenhuma das etnovariedades da dispersão, inclusive as provenientes da mesma roça que a sua. Mas o seu afastamento foi pequeno, se comparado ao afastamento da DG71.

Interessante foi o posicionamento da variedade padrão Mantiqueira. A origem materna desta variedade é a variedade Santa, que por sua vez é originária do litoral norte paulista (Normanha \& Boock, 1942). Nota-se, que ela foi muito mais próxima na dispersão, das etnovariedades do Rio Negro, do que as do litoral sul do Est. de São Paulo. Aliás, até o material do Rio Solimões apresenta etnovariedades mais próximas da Mantiqueira do que o paulista.

Nas figuras 2, 3 e 4, estão as dispersões gráficas $\mathrm{VC} 1 \times \mathrm{VC} 2$, respectivamente para etnovariedades provenientes do Rio Negro, do Rio Solimões e do litoral sul do Est. de São Paulo. Nas figuras fica claro que a região que apresentou maior diversidade foi a do Rio Negro, seguida do Rio Solimões e finalmente do litoral sul do Est. de São Paulo.

O interessante, é que de certa forma, as dispersões das regiões se sobrepuseram (figura 5). Sendo que, poucas etnovariedades provenientes das regiões do Rio Solimões (DG122) e do litoral sul do Est. de São Paulo (DG127, DG128 e DG131) fogem da dispersão apresentada pelas etnovariedades do Rio Negro.

Na figura 6 está a dispersão gráfica da variável canônica 1 versus variável canônica 2 ( $\mathrm{VCl} \times \mathrm{VC} 2)$, onde foram plotadas as 56 etnovariedades identificadas pela roça de origem (Tabela 1). No geral, as etnovariedades componentes de cada roça, dispersaram-se na distribuição, o que demonstra a variabilidade dentro das roças.

$\mathrm{Na}$ figura 7 está a dispersão tridimensional VClxVC2xVC3. Observa-se que, com exceção do deslocamento da DG111, a adição da terceira variável canônica pouco altera a distribuição das etnovariedades. 
A dispersão multivariada através das variáveis canônicas confirma os resultados obtidos no desdobramento da variância genética. A área do Rio Negro é realmente a região que apresenta maior diversidade genética, seguida do Rio Solimões e do litoral sul do Estado de São Paulo.

Estes resultados confirmaram nossas expectativas, pois a região do Rio Negro é conhecida pela concentração de tribos indigenas com tradição no cultivo da mandioca (Ribeiro, 1995), especialmente as que falam linguas pertencentes as familias Aruák e Tukâno.

A diversidade encontrada nas regiões do Rio Solimões e do litoral Sul do Estado de São Paulo também foram significativas e devem ser adicionadas às áreas com alta diversidade intraespecifica da mandioca.

\subsubsection{Divergência genética por distância de Mahalanobis}

Na Tabela 45 estão apresentadas as estimativas da distância generalizada de Mahalanobis para as 56 etnovariedades. Os valores da maior distância e da menor distância estão realçados em negrito para cada etnovariedade na Tabela. A média das estimativas das distâncias foi de 852,21, com mínimo de 90,41 entre as etnovariedades DG39 e DG67 e máximo de 5974,10 entre as etnovariedades DG71 e DG118.

$\mathrm{Na}$ figura 8 está representado o dendrograma UPGMA para as 56 etnovariedades. No dendrograma podem ser observadas as relações detalhadas entre as etnovariedades.

Confirma-se, o grande afastamento da etnovariedade DG71 das demais, e a formação de um grande bloco com variação mais contínua, sendo que na periferia a direita e a esquerda do dendrograma estão as etnovariedades mais afastadas.

Com poucas exceções, não há formação de agrupamentos segundo a roça de coleta e a origem geográfica, demonstrando que não foi detectada variação geográfica 
nas etnovariedades. A ausência de variação geográfica é indício da presença de fluxo genético entre as populações.

Uma exceção parece ser o agrupamento formada pelas etnovariedades DG127, DG128 e DG131, todas originárias do litoral sul do Est. de São Paulo. Reportando-se a figura 1 nota-se que elas realmente preenchem um vazio em relação a distribuição de outras regiões.

No geral, o dendrograma foi concordante com a distribuição gráfica dos escores das primeiras variáveis canônicas, o que demonstra que a distorção provocada pela relativa dispersão da variância nas 4 primeiras variáveis canônicas foi pequena.

Comparando a Tabela 45 e a figura 8 , observa-se que o dendrograma também apresenta distorção, devido a função de agrupamento. Por exemplo a etnovariedade mais próxima da DG38 foi a DG65 com distância de 378,86 (Tabela 45), já a etnovariedade mais próxima da DG122 foi a DG129 com distância de 410,85. Portanto a DG122 foi mais afastada das demais do que a DG38, o que não ocorreu no dendrograma UPGMA. Neste caso a distribuição dos escores das variáveis canônicas foi mais fiel a realidade (figura 1 ). 


\section{CONCLUSÕES}

Os resultados obtidos no presente trabalho permitem as seguintes conclusões:

1. A diversidade fenotípica das etnovariedades avaliadas é bastante ampla.

2. A diversidade genética das etnovariedades também é bastante ampla.

3. De modo geral, a divergência multivariada apresentada pelos etnovariedades foi ampla e contínua, com exceção da etnovariedade DG71 que se distanciou bastante das demais.

4. O afastamento da etnovariedade DG71 sugere que em sua população de origem esteja ocorrendo hibridação introgressiva.

5. Na média dos 31 descritores avaliados, mais de $75 \%$ da variância genética total foi devida a componente dentro de roças ou dentro da população, o que se aproxima da distribuição da variância genética em populações de espécies naturais preferencialmente alógamas. 
6. A magnitude da concentração da variabilidade genética dentro das roças é sinal de que fluxo genético entre as população deva estar ocorrendo, e neste caso a introdução ou troca de etnovariedades ganha especial importância, na dinâmica evolutiva da mandioca.

7. Na amostragem para coleta de germoplasma de mandioca, deve ser considerada a concentração da variabilidade genética dentro da roça ou dentro da população.

8. As etnovariedades provenientes da região do Rio Negro foram as que apresentaram maior diversidade genética, seguida das etnovariedades da região do Rio Solimões e por fim das etnovariedades provenientes do litoral sul do Estado de São Paulo.

9. A região do Rio Negro, devido a sua extensão territorial e concentração de um grande número de tribos indígenas cuja ênfase é o cultivo da mandioca deve ser prioritária para futuras coletas de mandioca, principalmente as regiões não compreendidas por esta coleta como o alto Rio Negro, Rio Uaupés e Rio Içana.

10. Não foi encontrada variação geográfica.

11. A magnitude da variação genética encontrada e a utilidade desta ao melhoramento demonstram a importância da conservação in situ de germoplasma. 
12. O sentido e a magnitude da correlação genética encontrada entre os descritores quimicos da raiz facilitou o aumento do teor de amido na domesticação.

13. A correlação genética negativa entre os teores de carboidratos e de fibras do caule facilitou o aumento da elementos de reserva no caule, fundamental na brotação de estacas na propagação vegetativa.

14. A correlação genética entre caracteres do caule e da raiz merece ser melhor investigada.

15. Os descritores de ácido cianídrico das raizes não apresentaram alta correlação genética com os descritores agronômicos.

16. As correlações genéticas encontradas devem ser investigadas em populações segregantes, formadas a partir das etnovariedades.

17. Não houve relação entre o uso das etnovariedades pelos agricultores e os potenciais cianogênico encontrados na região de Piracicaba.

18. No geral, a variabilidade genética expressa pelos descritores quimicos das folhas foi baixa.

19. No geral, a variabilidade genética expressa pelos descritores químicos do caule e das raizes foi alta.

20. No geral a variabilidade genética expressa pelos descritores agronômicos foi alta. 
21. O descompasso demonstrado pela variabilidade descrita pelos caracteres quimicos das folhas, em relação aos outros caracteres, pode significar que a mandioca apresenta baixa variabilidade intraespecífica para estes caracteres. 


\section{REFERÊNCIAS BIBLIOGRÁFICAS}

ALLEM, C.A. A revision of Manihot section Quinquelobae (Euphorbiacea). Revista Brasileira de Biologia, v. 49, n. 1, p. 1-26, 1989a.

ALLEM, C.A. Four new species of Manihot (Euphorbiaceae) from Brasil. Revista Brasileira de Biologia, v.49, n. 1, p.649-662, 1989 b.

ALMEIDA, E. Diversidade genética de espécies cultivadas em áreas de agricultura tradicional de Mata Atlântica do Estado de São Paulo. Piracicaba, 1997. 55p. Relatório Final (Residência Agronòmica). Escola Superior de Agricultura "Luíz de Queiroz", Universidade de São Paulo.

AMERICAN ASSOCIATION OF CEREAL CHEMISTS. Approved Methods of the American Cereal Chemists. 9.ed.St. Paul: AACC, 1995. 2v.

ASSOCIATION OF OFFICIAL ANALYTICAL CHEMISTS. Official methods of analysis . 12. ed. Washington: AOAC, 1975. 1094p.

ACOSTA-ESPINOZA, J. Variabilidade e associações genéticas entre caracteres de mandioca (Manihot esculenta Crantz) combinando policruzamentos e propagação vegetativa. Piracicaba, 1984. 118p. Tese (Doutorado) - Escola Superior de Agricultura "Luiz de Queiroz", Universidade de São Paulo. 
ALBUQUERQUE, M; CARDOSO, E.M.R. A mandioca no trópico úmido. Brasilia: Editerra, 1980. 251p.

ALLEM, C.A. A revision of Mamihot section Quinquelobae (Euphorbiaceae). Revista Brasileira de Biologia, v.49, n. 1, p.1-26, 1989a.

ALLEM, C.A. Four new species of Manihot (Euphorbiaceae) from Brazil. Revista Brasileira de Biologia, v.49, n.3, p. 649-62, 1989 b.

BAI, K.V.; ASIEDU, R.; DIXON, A.G.O. Cytogenetics of Manihot Species and Interspecific Hybrids. In: International Scientific Meeting of the Cassava Biotechnology Network, n.1. Proceedings CBN. Cartagena de Indias: CIAT, 1992. p.51-55.

BARRIGA, R.H.M.P. Caracterização de cultivares de mandioca (Manihot esculenta, Crantz) com relação a produção e estabilidade. Piracicaba, 1980. 128p. Dissertação (Mestrado) - Escola Superior de Agricultura "Luíz de Queiroz", Universidade de São Paulo.

BOKANGA, M. Distribution of cyanogenic potencial in the cassava germplasm. Acta Horticulturae, v.375, p.117-123, 1994a.

BOKANGA, M. Processing of cassava leaves for human consumption. Acta Horticulturae, v.375, p. 203-207, 1994b.

BOKANGA, M.; EKANAYAKE, I.J.; DIXON, A.G.O.; PORTO, M.C.M.. Genotype interactions for cyanogenic potential in cassava. Acta Horticulturae, v.375, p.131139,1994 
CEREDA, M.P. Residuos da industrialização da mandioca no Brasil. São Paulo: Paulicéia, 1994. p.11-50: Caracterização dos resíduos da industrialização da mandioca.

CEREDA, M.P.. Valorização de residuos como forma de reduzir custos de produção. In: Congresso Latino Americano de Raizes Tropicais, 1., resumos. São Pedro: Centro de Raizes Tropicais - UNESP, 1996. p. 25-43.

CHERNELA, J.M. Os cultivares de mandioca na área do Uaupés (Tukâno). In: Ribeiro, B.G. Suma etnológica brasileira. Petrópolis: Vozes, 1987. p. 150-158.

CONCEIÇÃO, A. J. Mandioca. 3.ed. São Paulo: Nobel, 1987. 382 p.

COOKE, R.D. Enzymatic assay for total cyanide content of cassava (Manihot esculenta, Crantz). Journal of the Sciense of Food and Agriculture, v.29, n.4, p. 345-352, 1978.

CRUZ, C.D.; REGAZZI, A.J.. Modelos biométricos aplicados ao melhoramento genético. Viçosa: Imprensa Universitária, 1994. 390p.

CRUZ, N.D. Citologia no gênero Manihot Adams. I - Determinação do número de cromossomos em algumas espécies. Anais da Academia Brasileira de Ciências, v. 40, n. 1, p. $91-5,1968$.

CURI, P.R. Análise de agrupamentos: métodos seqüenciais, aglomerativos e hierárquicos. Ciência e Cultura, v. 35, n.10, p. 1416-1429. 1983. 
CURY, R. Dinâmica evolutiva e caracterização de germoplasma de mandioca (Manihot esculenta, Crantz) na agricultura autóctone do sul do estado de São Paulo. Piracicaba, 1993. 103p. Dissertação (Mestrado) - Escola Superior de Agricultura "Luíz de Queiroz", Universidade de São Paulo.

DANTAS, J.L.L, Genótipos de Mandioca (Manihot esculenta, Crantz) para programas de seleção no Recôncavo Baiano. Piracicaba, 1984. 103p. Dissertação (Mestrado) Escola Superior de Agricultura "Luíz de Queiroz", Universidade de São Paulo.

DIXON, A G. O; ASIEDU, R.; BOKANGA, M. Breeding of cassava for low cyanogenic potential: problems, progress and prospects. Acta Horticulturae, v.375, p. 153-161, 1994.

DUFOUR, L.D. Cyanide content of cassava (Manihot esculenta, Euphorbiaceae) cultivars used by Tukanoan indians in northwest Amazonia. Economic Botany,v. 42 , p. $254-266,1988$.

ESSER, A.J.A. Futher improving the enzymic assay for cyanogens in cassava products. Acta Horticulturae, v.375, p.97-104, 1994.

FUKUDA, W.M.G.; COSTA; I.R.S.; VILARINHOS, A.D.; OLIVEIRA, R.P. Banco de Germoplasma de Mandioca: Manejo, Conservação e Caracterização. Cruz das Almas: EMBRAPA- CNPMF, 1996. (Documento, 68)

FUTUYMA, D.J. Biologia evolutiva. 2. ed. Ribeirão Preto: Sociedade Brasileira de Genética, 1993.646p.

GRANER, E.A. Contribuição para o estudo citológico da mandioca. Piracicaba: ESALQ/USP, 1935. 28p. 
GRANER, E.A. Genética de Manihot. I. Hereditariedade da forma da folha e da coloração da película externa das raizes em Manihot utilissimum Pohl. Bragantia, v.2, p.13-22, 1942.

HERSHEY, C.; AMAYA, A. Germoplasma de yuca. Evolución, distribuicion y coleccion. In: DOMINGUEZ, C.E. Yuca: investigación, producción y utilización. Cali:Ciat, 1984a. p.77-79.

HERSHEY, C.; AMAYA, A. Genetica, citogenetica, estrutura floral y tecnica de hibridacion de la yuca. In: DOMINGUEZ, C.E. Yuca: investigación, producción y utilización. Cali:Ciat, 1984b. p.113-25.

HERSHEY, C.; OCAMPO, C.H.. Descripcion de nuevos marcadores genéticos de yuca. Yuca Boletín Informativo, v. 13, n. 1, p.3-5, Ago. 1989.

JENNINGS, D.L. Cassava. In: SIMMONDS, N.W. Evolution of crop plants. London, Longman, 1979. p.81-4.

JENNINGS, D.L. Manihot melanobasis Mull-Arg. - a usefull parent for cassava breeding. Euphytica, v.8, p.157-63, 1959.

JENNINGS, D.L. Variation in pollen and ovule fertility in varieties of cassava and the effect of interspecific crossing on fertility. Euphytica, v. 12, p. 69-76, 1963.

KAWANO, K.; AMAYA, P.; RIOS, M. Factors affecting efficienty of hybridization and selection in cassava. Crop Science, v. 17, p.373-6, 1978. 
KAWANO, K. Mejoramento genetico de yuca para produtividad. In: DOMINGUEZ, C.E. Yuca: investigación, producción y utilización. Cali:Ciat, 1984. p.91-111.

KOCK, L. Cassaveselectie. Wageningen: H. Veenman \& Zonen, 1933. 86 p.

LATHARAP, D W. The antiquity and importance of long -distance trade relationships in the moists tropics of Pre-Colombian South American. Word Archaeology, v.5, p. 170-186, 1973.

LORENZI, J.O. Variação de carboidratos e ácido cianidrico em raizes de mandioca, após a poda da parte aérea. Bragantia, v.37, n.16, p.139-144. 1978.

MAGOON, M.L.; KRISHNAN, R.; BAI, K.V. Morphology of the pachytene chromossome and meiosis in Manihot esculenta Crantz. Cytologia, v.34, p.612$625,1969$.

MARTINS, P.S. Evolução e biologia de populações de plantas. In: Encontro Sobre Temas de Genética e Melhoramento,13., Piracicaba, 1996. Anais. Piracicaba: Departamento de Genética, 1996. p.147-165.

MARTINS, P.S. Cassava collection. In: MORISHIMA, H.; MARTINS, P.S. Investigations of plant genetic resources in the amazon basin with emphasis on the genus Oryza. Mishima: Monblio International Scientific Research, 1994. 100p.

MARTINS, P.S. Biodiversity and agriculture: patterns of domestication of Brasilian Native Plant. An. Acad. Bras. Ci., 66: 219-223. 1994b.

NASSAR, N.M.A. Genetic resources of cassava. Chromosome number in Manihot spp. Indian Journal of Genetics and Plant Breeding, v.38, p. 135-7, 1978a. 
NASSAR, N.M.A. Interespecific hybridization between cassava and some Manihot species. Egyptian Journal of Genetic and Citology, v.8, p.175-179, 1978b.

NASSAR, N.M.A. Microcenter of cassava diversity in central Brazil. Turrialba, v.28, p. 345-347, 1978c.

NASSAR, N.M.A. The need for germplasm conservation in wild cassava, Manihot spp. Indian Journal of Genetics and Plant Breedings, v.39, p.465-470, 1979.

NORMANHA E.S. Diferenças entre mandioca mansa e brava. O Agronômico, v.8, p.14, 1956.

NORMANHA E.S ; BOOCK, O.J. Ensaios de variedades de mandioca na estação experimental de Ubatuba. Bragantia, v.2, p.520-559, 1942.

PEREIRA, A.V. Utilização da análise multivariada na caracterização de germoplasma de mandioca (Manihot esculenta Crantz). Piracicaba, 1989. 180p. Tese (Doutorado) Escola Superior de Agricultura "Luiz de Queiroz", Universidade de São Paulo.

PERONI, N. Taxonomia folk e diversidade intraespecifica de mandioca (Manihot esculenta, Crantz) em roças de agricultura tradicional em áreas de Mata Atlântica do Sul do Estado de São Paulo. Piracicaba, 1998. 100p. Dissertação (Mestrado) Escola Superior de Agricultura "Luíz de Queiroz", Universidade de São Paulo.

PERRY, B.A. Chromosome number and phylogenetic relationship in the Euphorbiaceae. American Journal of Botany, v.30, p.527-43, 1943. 
REICHEL-DOLMANTOFF, G. Colombia. New York: Frederick a Praeger, 1965. 231p. (Ancient Peoples and Places, 44)

RBEIRO, B. G. Os índios das águas pretas: modo de produção e equipamento produtivo. São Paulo: EDUSP, 1995. 270p.

ROGERS, D.J. Studies of Manihot esculenta, Crantz, and related species. Bulletin of the Torrey Botanical Club, v.90, n.1, p.44-54, 1963.

ROGERS, D.J. ; APPAN, S.J. Manihot and Manihotoides (Euphorbiaceae). Flora Neotropica, Monograf 13, 1973. 272p.

ROUSE, Y ; CRUXENT, J.M. Venezuelan Archaeology. London: Yale, 1963 179p. (Caribean Series, 6)

SCHAAL, B.; OLSON, P.; PRINZIE, T.; CARVALHO, L.J.C.B.; TONUKARI, N.J.; HAYWORTH, D. Phylogenetic analysis of the genus Manihot based on molecular markers. In: International Scientific Meeting of the Cassava Biotechnology Network, n.2. The Cassava Biotechnology Network: Working Document No. 150. Bogor: CIAT, 1994. p.62-70.

SELMAR, D. Translocation of Cyanogenic Glucosides in Cassava. Acta Horticulturae, v. 375, p.61-67. 1994.

SILVA JARDIM, J.R. Hibridação interespecifica no gênero Manihot Adams. Viçosa, 1984. 74p. Dissertação (M.S.) - Universidade Federal de Viçosa.

SNEATH, P.H.A.; SOKAL, R.R. Numerical taxomomy: the principles and pratice of numerical classification. San Francisco: W.H. Freeman, 1973. 573p. 
SINHA, S.K.; NAIR, T.V.R. Studies on the Variability of Cyanogenic Glucoside Content in Cassava Tubers. Indian J. Agric. Sci., v. 38, p.958-964. 1968.

STEBINS, G.L. Processos de evolução orgânica. São Paulo: Polígono, 1970. 255p.

STOREY, H.H. ; NICHOLS, R.F.W. Studies of mosaic of cassava. Annals Appliel Biology, v.25, n.4, p.790-806, 1938.

UMANAH, E.E. \& HARTMANN, R.W. Cromosome numbers and karootypes of some Manihot species. Journal of American Society Horticultural Science, v.98, n.3, p.272-274, 1973.

VALLE, T.L. Cruzamentos dialélicos em mandioca (Manihot esculenta Crantz) Piracicaba, 1990. 180p. Tese (Doutorado) - Escola Superior de Agricultura "Luiz de Queiroz", Universidade de São Paulo.

VENCOVSKY, R.; BARRIGA, P. Genética biométrica no fitomelhoramento. Ribeirão Preto. Sociedade Brasileira de Genética. 1992. 496p.

WHEATLEY, C.C.; ORREGO, J.I.; SANCHEZ, T.; GRANADOS, E.. Quality of the cassava core collection at CIAT. In: International Scientific Meeting of the Cassava Biotechnology Network, n.1. Proceedings CBN. Cartagena de Indias: CIAT, 1992. p. $255-264$. 
Figura 1. Dispersão de todas as etnovariedades avaliadas, segundo as duas primeiras variáveis canônicas.

Dispersão completa: 56 etnovariedades - Var. 57,89\%.

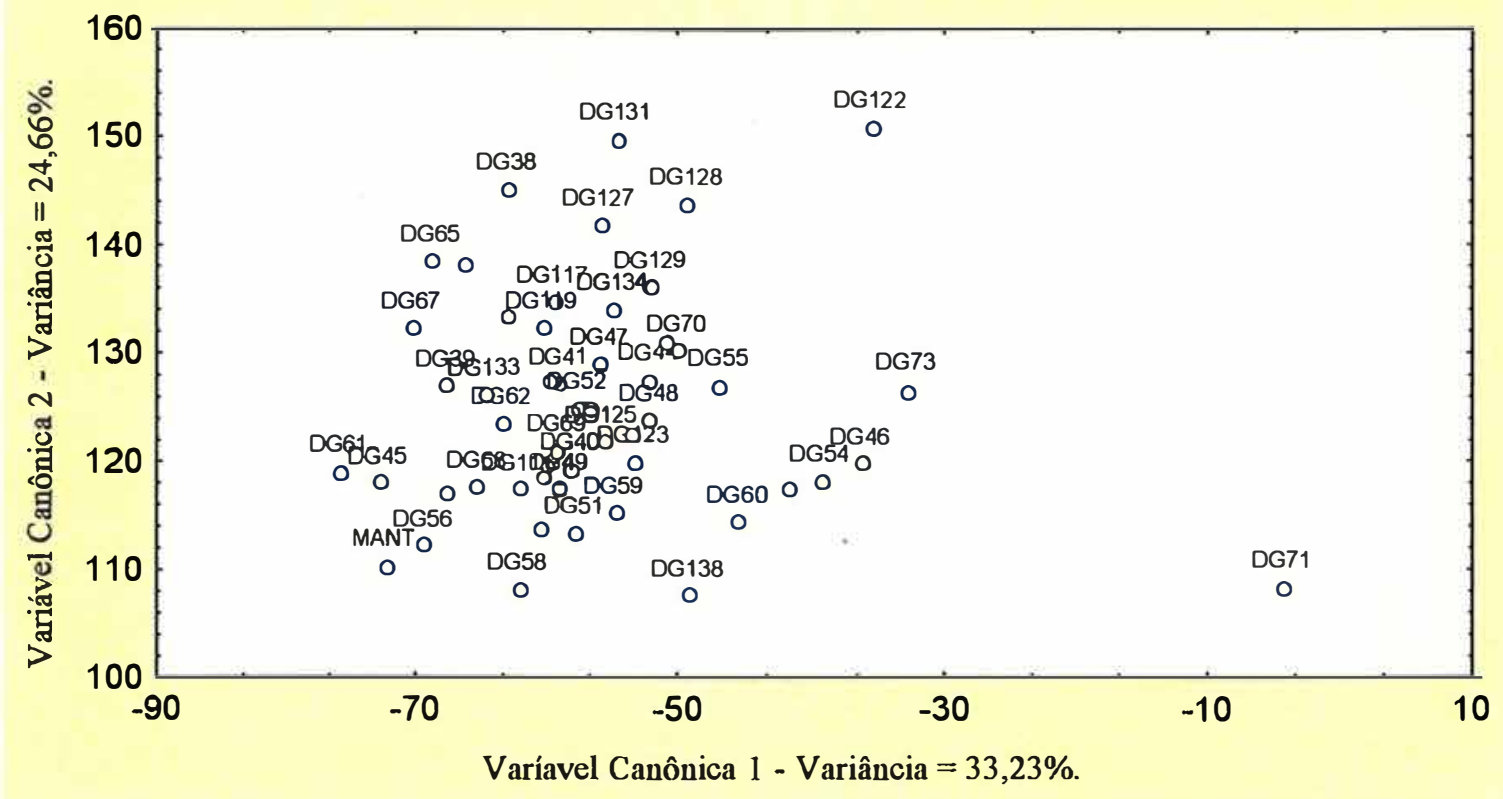

Figura 2. Dispersão das etnovariedades da região do Rio Negro e a variedade padrão Mantiqueira, segundo as duas primeiras variáveis canônicas.

Dispersão das Etmovariedades do Rio Negro - Variância representada 57.89\%.

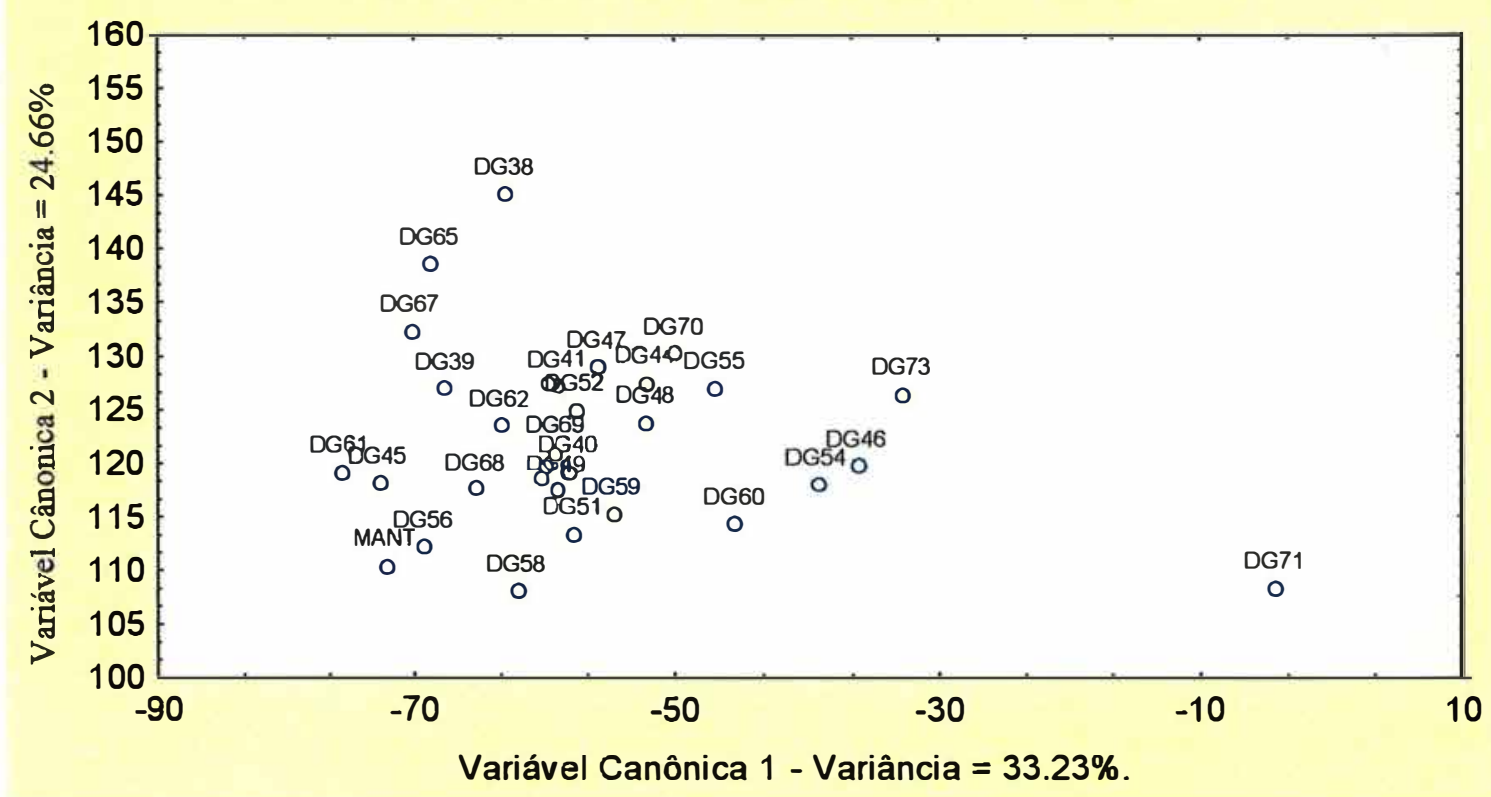


Figura 3. Dispersão das etnovariedades da região do Rio Solimões e a variedade padrão Mantiqueira, segundo as duas primeiras variáveis canônicas.

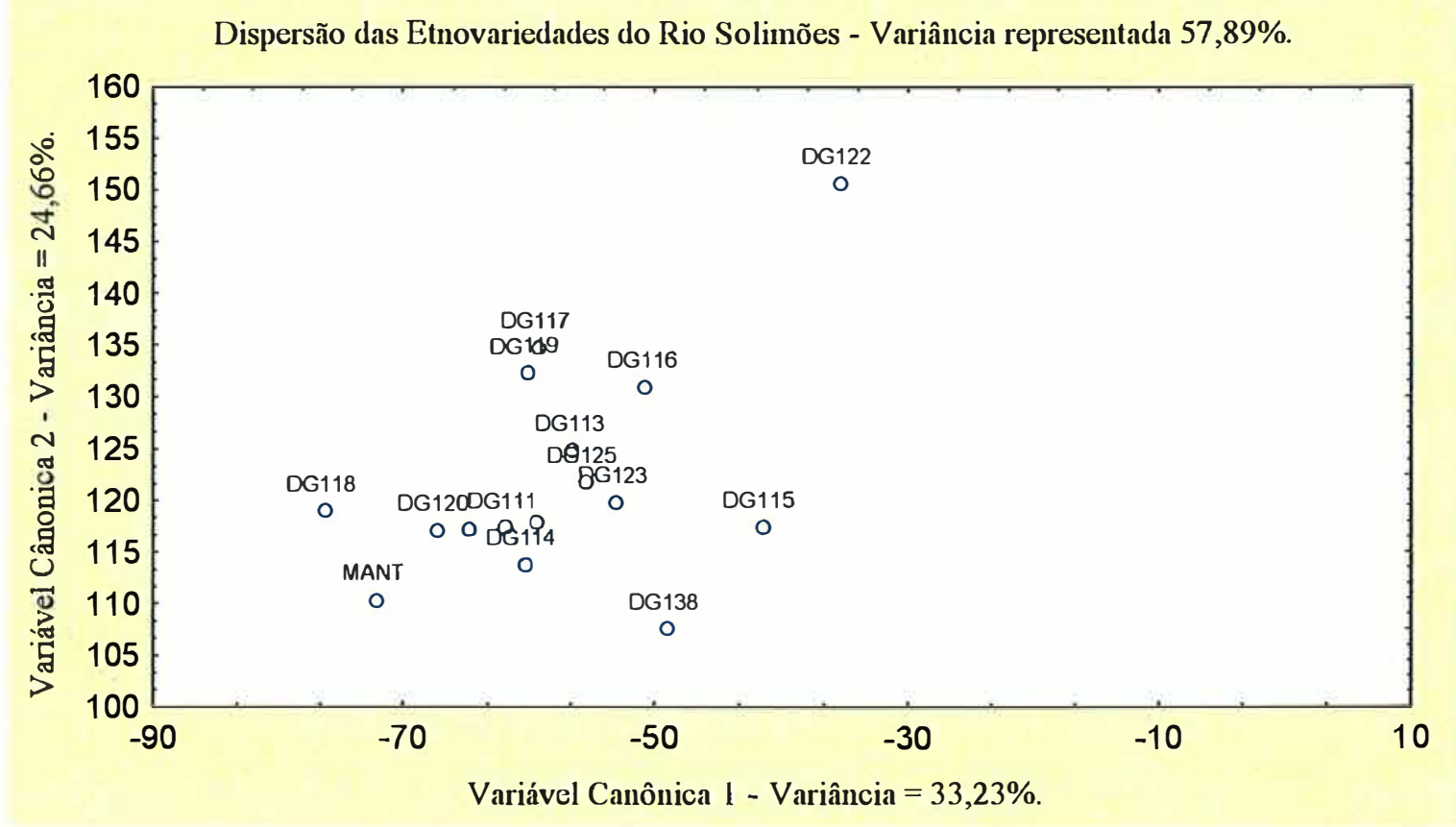

Figura 4. Dispersão das etnovariedades da região do litoral sul do Estado de São Paulo e a variedade padrão Mantiqueira, segundo as duas primeiras variáveis canônicas.

Dispersão das Etnovariedades do Litoral Sul de SP - Variância representada 57,89

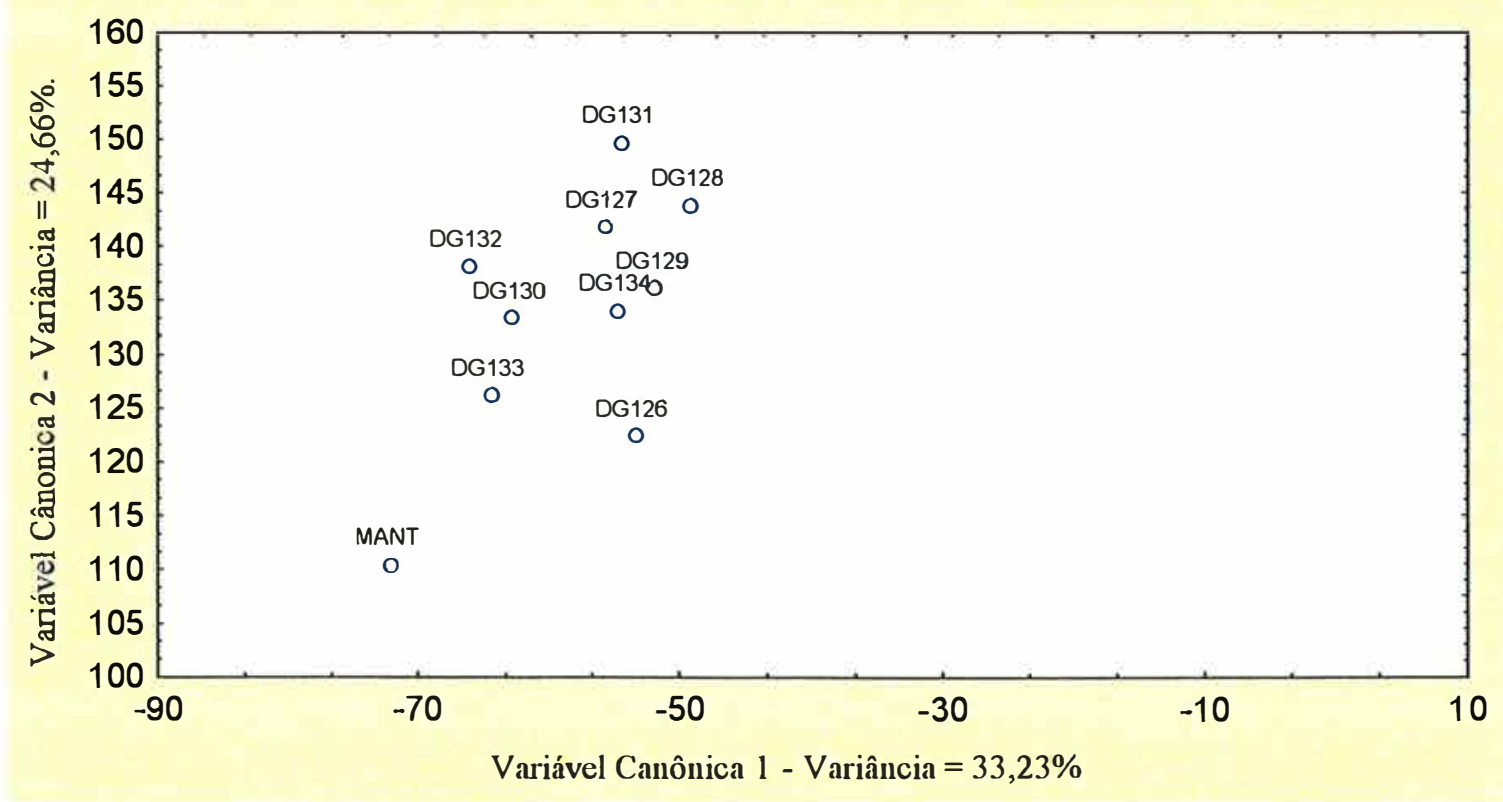


Figura 5. Dispersão das 56 etnovariedades identificadas pela região de origem, segundo as duas primeiras variáveis canônicas.

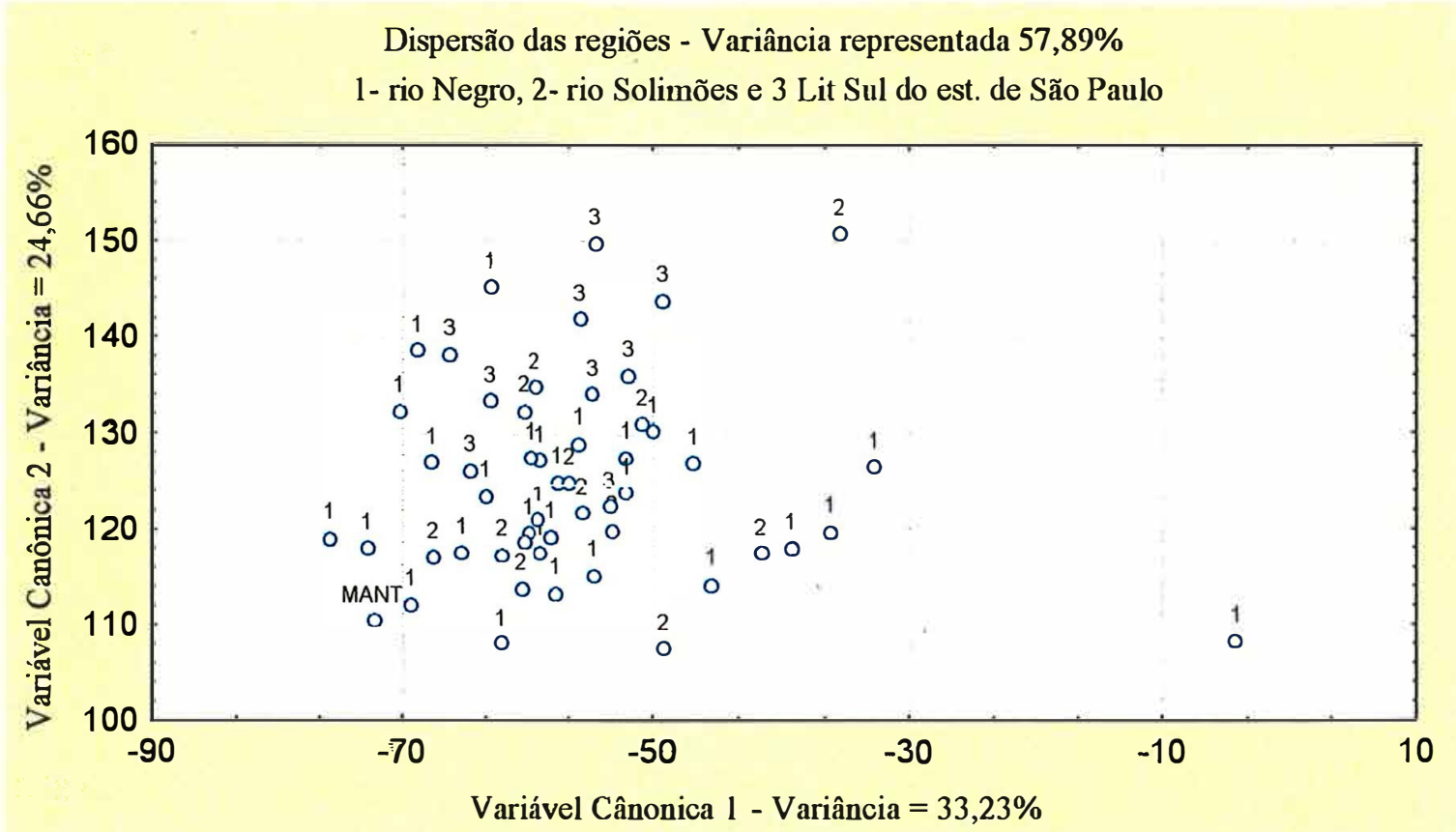

Figura 6. Dispersão das 56 etnovariedades identificadas pela roça (população) de origem, segundo as duas primeiras variáveis canônicas.

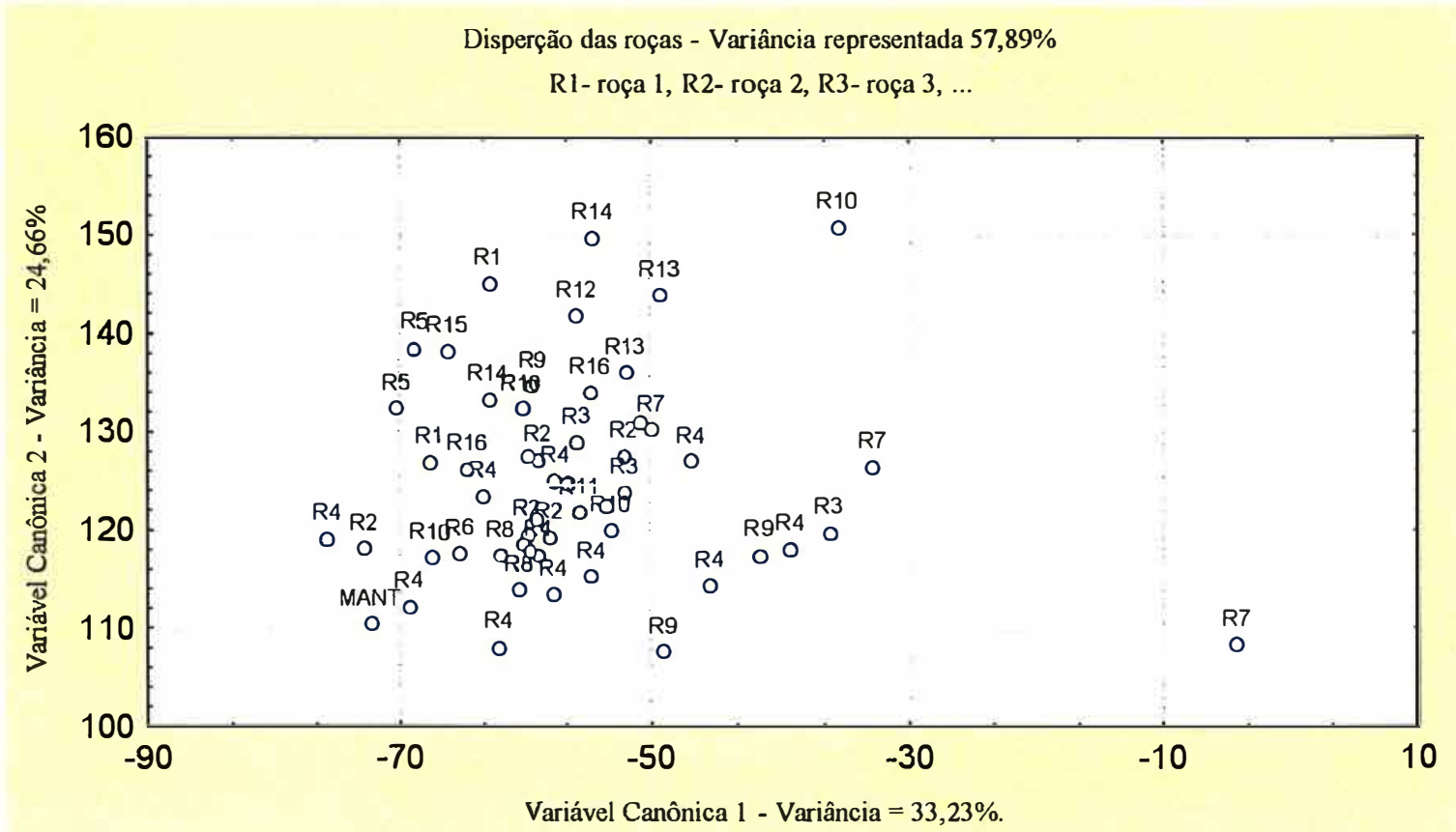


Figura 7. Dispersão tridimensional das 56 etnovariedades avaliadas, segundo as três primeiras variáveis canônicas.

Dispersão Tridimensional - Variância representada 69,68\%

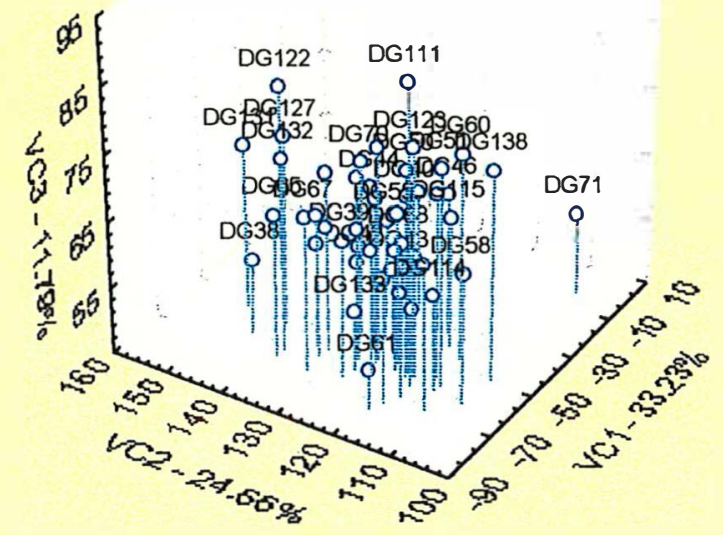

Figura 8. Dendrograma UPGMA, utilizando como medida de dissimilaridade a distância de Mahalanobis

Dendrograma completo: 56 etnovariedades

UPGMA

Distância de Mahalanobis

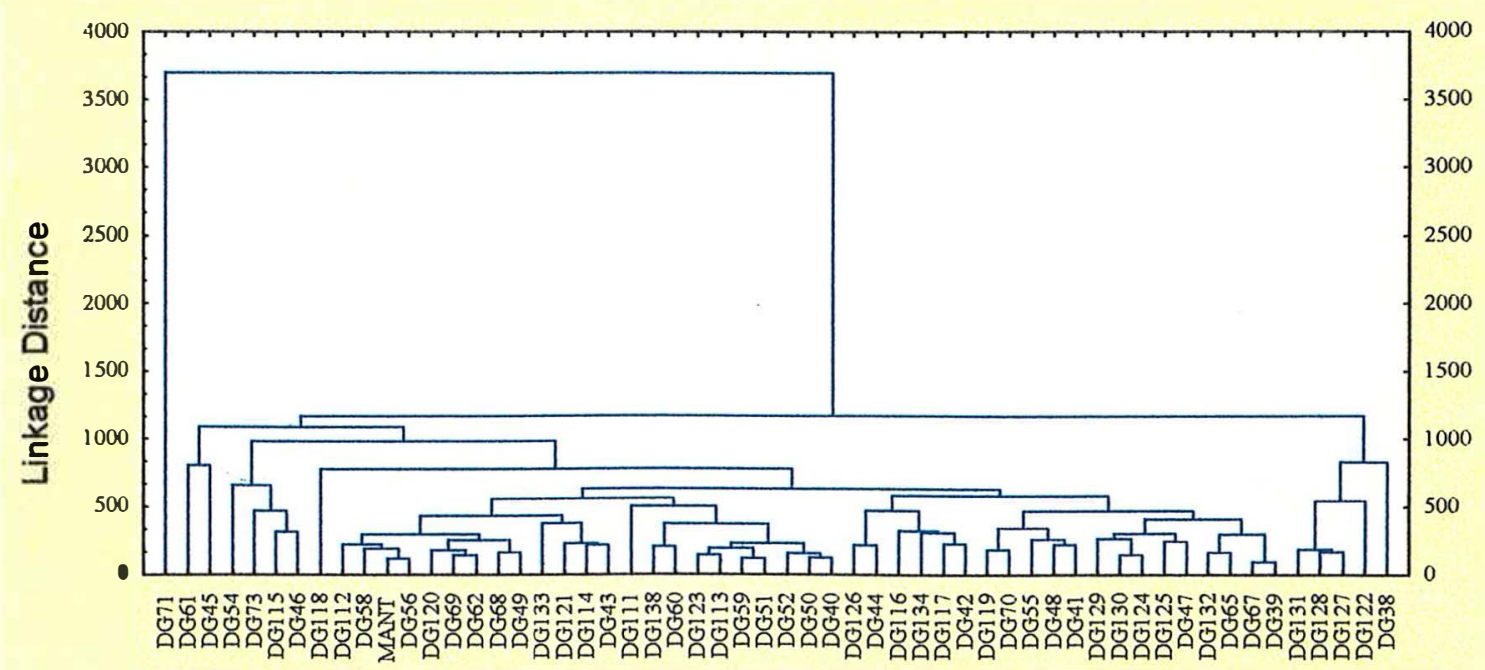


Tabela 1. Etnovaridades de mandioca (., Hanihot esculenta, Crantz) avaliadas.

\begin{tabular}{lllll}
\hline IDENT & LOCALDADE & ROÇA & NOME LOCAL & USO
\end{tabular}

I. B.ACLA DO RIO .IEGRO - AM. 7 LOC.LLID.ADES, 7 ROÇAS E 3O ETNOVARIEDADES

\begin{tabular}{|c|c|c|c|c|c|}
\hline DG-38 & COMUNIDADE PILOTO & 1 & MANIVA INAJÁ & FARINHA & LOCAL \\
\hline DG-39 & BARCELOS - AM & 1 & MACAXEIRA BRANCA & MESA & LOCAL \\
\hline DG -10 & COMUNIDADE MARARÁ & 2 & BRANQUINHA & FARINHA & LOCAL \\
\hline DG-11 & BARCELOS - AM & 2 & SEM NOME & FARINHA & LOCAL \\
\hline$D G-12$ & NDIOS TUKÂNO & 2 & MANDIOCA SĀO JOÃO & FARINHA & LOCAL \\
\hline DG-43 & & 2 & PRETINHA & FARINHA & LOCAL \\
\hline DG-4t & & 2 & MANDIOCA DO ANTONIO & FARINHA & LOCAL \\
\hline DG -45 & & 2 & MACAXEIRA & MESA & LOCAL \\
\hline DG -46 & COMUNWADE D. PEDRO II & 3 & ORELHA DE BURRO & FARINHA & LOCAL \\
\hline DG-47 & BARCELOS / ANATI - AM & 3 & MAMAROCA & FARINHA & LOCAL \\
\hline DG-48 & & 3 & TARTARUGA & FARINHA & LOCAL \\
\hline DG-49 & CARVOEIRO - AM & 4 & AMARELA II & FARINHA & LOCAL \\
\hline DG-50 & & 4 & OLHO ROXO & FARINHA & LOCAL \\
\hline DG-51 & & 4 & PRETINHA & FARINHA & LOCAL \\
\hline DG-52 & & 4 & SEIS MESES & FARINHA & LOCAL \\
\hline DG-54 & & 4 & ANIINHA & FARINHA & LOCAL \\
\hline DG-55 & & 4 & ANARÁ & FARINHA & LOCAL \\
\hline DG-56 & & 4 & ARAOARI & FARINHA & LOCAL \\
\hline DG-58 & & 4 & AMARELA I & FARINHA & LOCAL \\
\hline DG-59 & & 4 & SAMUAUMA & FARINHA & LOCAL \\
\hline DG-60 & & 4 & SEM NOME I & FARINHA & LOCAL \\
\hline DG-61 & & 4 & MACAXEIRA & FARINHA & LOCAL \\
\hline DG-62 & & 4 & SEM NOME II & FARINHA & LOCAL \\
\hline DG-65 & MARARA - RIO BRANCO - RR & 5 & ANARÁ & FARINHA & LOCAL \\
\hline DG-67 & & 5 & ROXINHA & FARINHA & LOCAL \\
\hline DG-68 & CASTANHO - RIO BRANCO - RR & 6 & MACAXEIRA PÃO & FARINHA & LOCAL \\
\hline DG-69 & & 6 & CAMARÃO & FARINHA & LOCAL \\
\hline DG-70 & PANACARICA - RIO BRANCO -RR & 7 & TALA ENCARNADA & FARINHA & LOCAL \\
\hline DG-71 & & 7 & ANTA & FARINHA & LOCAL \\
\hline DG-73 & & 7 & SOCÓ & FARINHA & LOCAL \\
\hline
\end{tabular}


Tabela 1. Enovaridades de mandioca (.Manihot esculenta, Crantz) avaliadas (continuação).

\begin{tabular}{llllll}
\hline IDENT & LOCALIDADE & ROÇA & NOME LOCAL & USO
\end{tabular}

II. RIO SOLRÕES - AM. + LOC.LLID.ADES. + ROÇAS E 16 ETNOVARIEDADES.

$\begin{array}{llllll}\text { DG-111 } & \text { COMUNIDADE SÃO SEBASTIÃO } & 8 & \text { GEOATÓ } & \text { FARINHA } & \text { LOCAL } \\ \text { DG-112 } & \text { UARINI - AM } & 8 & \text { PRETINHA } & \text { FARINHA } & \text { LOCAL } \\ \text { DG-113 } & \text { RIO SOLIMÕES } & 8 & \text { ANIINHA } & \text { FARINHA } & \text { LOCAL } \\ \text { DG-114 } & & 8 & \text { DE SEMENTTE } & \text { FARINHA } & \text { LOCAL } \\ & & & & & \\ \text { DG-115 } & \text { COMUNIDADE SÃO JOÃO } & 9 & \text { MAGUARI } & \text { FARINHA } & \text { LOCAL } \\ \text { DG-116 } & \text { GUARABIRA - AM } & 9 & \text { OURINHO } & \text { FARINHA } & \text { LOCAL } \\ \text { DG-117 } & \text { LAGO MAMIA } & 9 & \text { CANEORA } & \text { FARINHA } & \text { LOCAL } \\ \text { DG-118 } & & 9 & \text { MACAXERA } & \text { FARINHA } & \text { LOCAL } \\ \text { DG-138 } & & 9 & \text { ANIINHA } & \text { FARINHA } & \text { LOCAL } \\ & & & & & \\ \text { DG-119 } & \text { GUARABIRA - AM } & 10 & \text { MACAXEIRA } & \text { FARINHA } & \text { LOCAL } \\ \text { DG-120 } & \text { LAGO MAMIA } & 10 & \text { ANTINHA } & \text { FARINHA } & \text { LOCAL } \\ \text { DG-121 } & & 10 & \text { TURUNA } & \text { FARINHA } & \text { LOCAL } \\ \text { DG-122 } & & 10 & \text { MARRECA DE SEMENTE } & \text { FARINHA } & \text { LOCAL } \\ \text { DG-123 } & & 10 & \text { ANTINHA X MARRECA } & \text { FARINHA } & \text { LOCAL } \\ \text { DG-124 } & & 10 & \text { MACAXEIRA } & \text { FARINHA } & \text { LOCAL } \\ & & & & & \\ \text { DG-125 } & \text { LAGO ANANÃ - R SOLIMÕES - AM } & 11 & \text { SEM NOME } & \text { FARINHA } & \text { LOCAL }\end{array}$

III. LITORAL SLZ - SP, 2 LOCALIDADES. 5 ROÇAS E 9 ETNOVARIEDADES.

$\begin{array}{llllll}\text { DG-126 } & \text { CANANÉIA - SP } & 12 & \text { AIPIM ROXO } & \text { FARINHA } & \text { LOCAL } \\ \text { DG-127 } & \text { D. SATURNINA } & 12 & \text { AIPIM ROXO (SEMENTE) } & \text { FARINHA } & \text { LOCAL } \\ \text { DG-128 } & \text { CANANÉIA - SP } & 13 & \text { AIPIM MANTEIGA } & \text { MESA } & \text { LOCAL } \\ \text { DG-129 } & \text { S. NATALÍCIO } & 13 & \text { AIPIM MATA FOME } & \text { MESA } & \text { LOCAL } \\ & & & & & \\ \text { DG-130 } & \text { CANANÉIA - SP } & 14 & \text { AIPIM VASSOURINHA } & \text { MESA } & \text { LOCAL } \\ \text { DG-131 } & \text { SR. SÍLVIO RAMOS } & 14 & \text { AIPIM MANTEIGUINHA } & \text { MESA } & \text { LOCAL } \\ & & 15 & \text { AIPIM ROXO } & \text { MESA } & \text { LOCAL } \\ \text { DG-132 } & \text { CANANÉIA - SP / D. TUCA } & & & & \\ & & 16 & \text { MANTEIGA } & \text { MESA } & \text { LOCAL } \\ \text { DG-133 } & \text { LHA COMPRIDA - SP } & 16 & \text { AIPIM ROXO } & \text { MESA } & \text { LOCAL } \\ \text { DG-134 } & \text { PEDRINHAS / SR BENEDITO } & & & \end{array}$

IV. TESTEMUNHA, VARIEDADE IAC ILAVTIQUEIRA, ORIGEM MATERNA LITORAL NORTE DE SP. MANT I.A.C. (TESTEMUNHA) 17 MANTIQUERA 
Tabela 2. Características das etnovariedades.

\begin{tabular}{|c|c|c|c|c|c|c|c|c|c|c|c|c|c|c|c|c|}
\hline ETV & 1 & 2 & 3 & 4 & 5 & 6 & 7 & 8 & 91 & 10 & 111 & 12 & 13 & 14 & 15 & 16 \\
\hline DG-38 & 2 & 3 & 2 & 3 & 35.00 & 24.00 & 4.15 & 2 & 2 & 2 & 2 & 3 & 2 & 2 & 3.213 & 2.750 \\
\hline DG-39 & 2 & 3 & 2 & 1 & 33.50 & 19.75 & 6.55 & 1 & 2 & 2 & 1 & 2 & 2 & 2 & 0.890 & 1.600 \\
\hline$D G-40$ & 3 & 3 & 2 & 1 & 22.25 & 15.50 & 4.55 & 2 & 2 & 2 & 2 & 3 & 2 & 2 & 0.727 & 1.043 \\
\hline DG -41 & 2 & 2. & 2. & 1 & 21.75 & 15.60 & 3.85 & 2 & 2 & 2 & 2 & 3 & 2 & 2 & 0.703 & 0.867 \\
\hline DG -42 & 1 & 3 & 4 & 1 & 26.75 & 15.45 & 4.20 & 2 & 2 & 2 & 2 & 3 & 3 & 2 & 0.437 & 1.063 \\
\hline$D G-43$ & 2 & 3 & 2. & 1 & 33.50 & 21.50 & 5.50 & 2 & 2 & 2 & 2 & 3 & 3 & 2 & 1.420 & 3.450 \\
\hline DG -44 & 2 & 3 & 2. & 1 & 26.50 & 17.40 & 4.15 & 2 & 1 & 2 & 2 & 3 & 3 & 2 & 1.460 & 2.533 \\
\hline$D G-45$ & 2 & 3 & 2 & 1 & 32.75 & 20.30 & 6.55 & 2 & 2 & 2 & 2 & 2 & 2 & 2 & 1.937 & 3.037 \\
\hline DG-46 & 1 & 3 & 2 & 1 & 31.80 & 18.70 & 3.90 & 2 & 2 & 2. & 1 & 3 & 3 & 2 & 1.263 & 2.740 \\
\hline DG -47 & 2 & 3 & 4 & 3 & 33.25 & 22.35 & 3.50 & 2 & 1 & 1 & 1 & 1 & 1 & 2 & 1.980 & 4.197 \\
\hline DG -48 & 1 & 3 & 2 & I & 32.50 & 20.95 & 4.60 & 2 & 2 & 1 & 1 & 3 & 3 & 2 & 2.200 & 2.870 \\
\hline DG 49 & 1 & 2 & 2 & 1 & 22.75 & 16.25 & 4.70 & 2 & 2 & 2 & 2 & 3 & 3 & 2 & 1.400 & 1.883 \\
\hline DG-50 & 2 & 2 & 2. & 1 & 23.50 & 16.75 & 4.00 & 2 & 2 & 2 & 2 & 2 & 3 & 2 & 0.700 & 1.660 \\
\hline DG-51 & 2 & 3 & 2 & 1 & 24.00 & 17.25 & 5.00 & 2 & 2 & 2 & 2 & 3 & 3 & 2 & 1.310 & 3.227 \\
\hline DG-52 & 1 & 3 & 2 & 1 & 35.75 & 22.55 & 4.90 & 2 & 2 & 1 & 1 & 1 & 1 & 3 & 0.910 & 1.907 \\
\hline DG-54 & 3 & 3 & 4 & 1 & 33.00 & 24.00 & 4.75 & 2 & 2 & 2 & 2 & 3 & 3 & 2 & 0.407 & 1.230 \\
\hline DG-55 & 3 & 3 & 5 & 1 & 26.50 & 19.85 & 5.50 & 2 & 2 & 1 & 1 & 4 & 3 & 2 & 2.113 & 2.787 \\
\hline DG-56 & 1 & 3 & 2 & 1 & 28.50 & 19.00 & 3.65 & 2 & 2 & 2 & 2 & 4 & 3 & 2 & 1.370 & 4.387 \\
\hline DG-58 & 1 & 3 & 1 & 1 & 26.50 & 19.35 & 3.55 & 2 & 2 & 2 & 2 & 3 & 3 & 2 & 1.003 & 2.233 \\
\hline DG-59 & 1 & 2 & 2 & 1 & 23.25 & 16.00 & 4.45 & 2 & 2 & 2 & 2 & 3 & 3 & 2 & 0.623 & 1.070 \\
\hline DG-60 & 1 & 2 & 2 & 1 & 23.25 & 20.25 & 4.70 & 2 & 2 & 2 & 2 & 2 & 2 & 2 & 0.950 & 1.407 \\
\hline DG-61 & 2 & 3 & 2 & 1 & 28.50 & 17.80 & 5.35 & 2 & 2 & 2 & 2 & 3 & 1 & 2 & 1.433 & 2.237 \\
\hline DG-62 & 1 & 2. & 1 & 1 & 22.75 & 17.75 & 2.90 & 2 & 2 & 1 & 2 & 3 & 3 & 2 & 0.907 & 1.870 \\
\hline DG-65 & 3 & 3 & 4 & 1 & 33.75 & 19.65 & 6.10 & 2 & 2 & 2 & 2 & 4 & 1 & 2 & 3.790 & 3.077 \\
\hline DG-67 & 3 & 3 & 4 & 1 & 29.00 & 21.10 & 5.50 & 2 & 2 & 2 & 2 & 5 & 1 & 2 & 3.220 & 3.140 \\
\hline DG-68 & 2 & 2 & 2 & 4 & 28.50 & 20.50 & 5.70 & 1 & 2 & 2 & 2 & 2 & 2 & 2 & 2.337 & 2.620 \\
\hline DG-69 & 2 & 3 & 1 & 2 & 30.35 & 28.85 & 2.00 & 2 & 2 & 2 & 2 & 3 & 3 & 2 & 0.930 & 1.003 \\
\hline DG-70 & 1 & 2 & 4 & 1 & 23.75 & 16.10 & 5.30 & 2 & 2 & 2 & 2 & 3 & 3 & 2 & 1.230 & 1.427 \\
\hline DG-71 & 2 & 3 & 4 & 3 & 38.25 & 26.75 & 5.15 & 2 & 2 & 2 & 2 & 3 & 3 & 2 & 0.717 & 1.580 \\
\hline DG-73 & 2 & 2 & 2 & 1 & 39.00 & 26.15 & 6.95 & 2 & 2 & 2 & 2 & 2 & 2 & 2 & 3.320 & 3.620 \\
\hline DG-111 & 3 & 2 & 5 & 1 & 18.75 & 16.45 & 4.15 & 2 & 2 & 1 & 1 & 3 & 3 & 2 & 2.803 & 3.710 \\
\hline DG-112 & 1 & 3 & 2 & 1 & 21.75 & 18.25 & 4.70 & 2 & 2 & 2 & 2 & 3 & 3 & 2 & 1.097 & 2.877 \\
\hline DG-113 & 2 & 3 & 5 & I & 25.40 & 18.00 & 4.50 & 2 & 2 & 2 & 2 & 2 & 2 & 2 & 1.987 & 2.547 \\
\hline DG-114 & 1 & 2 & 2 & 1 & 29.00 & 22.85 & 5.15 & 2 & 2 & 1 & 1 & 3 & 3 & 2 & 1.527 & 2.507 \\
\hline DG-115 & 3 & 3 & 5 & 1 & 30.75 & 23.75 & 5.10 & 1 & 2 & 1 & 1 & 3 & 3 & 2 & 2.983 & 2.557 \\
\hline DG-116 & 2 & 3 & 4 & 1 & 35.75 & 26.00 & 5.00 & 2 & 2 & 2 & 2 & 3 & 3 & 2 & 2.087 & 3.303 \\
\hline DG-117 & 3 & 3 & 4 & 1 & 36.00 & 22.15 & 5.20 & 1 & 2 & 2 & 2 & 1 & 1 & 2 & 3.310 & 5.343 \\
\hline DG-118 & 3 & 3 & 2 & 1 & 35.25 & 20.25 & 5.55 & 1 & 2 & 2 & 2 & 2 & 1 & 2 & 2.420 & 4.153 \\
\hline DG-119 & 2 & 3 & 1 & 1 & 28.75 & 22.50 & 5.95 & 2 & 2 & 2 & 2 & 5 & 1 & 2 & 2.220 & 3.477 \\
\hline DG-120 & 3 & 3 & 5 & 1 & 32.25 & 18.10 & 4.00 & 2 & 2 & 2 & 2 & 3 & 3 & 2 & 1.603 & 2.807 \\
\hline DG-121 & 1 & 2 & 1 & 2 & 28.50 & 22.25 & 1.50 & 2 & 2 & 1 & 1 & 3 & 3 & 2 & 0.690 & 1.333 \\
\hline DG-122 & 2 & 2 & 4 & 3 & 19.15 & 17.00 & 1.35 & 2 & 2 & 2 & 2 & 2 & 2 & 2 & 1.097 & 0.917 \\
\hline DG-123 & 2 & 2 & 4 & I & 25.75 & 18.25 & 3.80 & 2 & 2 & 2 & 3 & 2 & 3 & 2 & 2.427 & 2.467 \\
\hline DG-124 & 1 & 2 & 4 & 1 & 29.75 & 19.60 & 5.30 & 1 & 2 & 2 & 1 & 4 & 1 & 2 & 2.717 & 2.907 \\
\hline DG-125 & 2 & 3 & 2 & 1 & 25.25 & 20.30 & 6.45 & 1 & 2 & 1 & 1 & 3 & 3 & 2 & 2.247 & 2.550 \\
\hline DG-126 & 1 & 2 & 4 & 1 & 25.25 & 17.50 & 4.65 & 2 & 2 & 2 & 1 & 4 & 1. & 2 & 4.223 & 2.770 \\
\hline DG-127 & 3 & 2 & 4 & 2 & 33.75 & 22.45 & 2.25 & 2 & 2 & 2 & 2 & 1 & 1 & 2 & 5.493 & 4.780 \\
\hline DG-128 & 2 & 2 & 5 & 1 & 32.60 & 20.50 & 5.40 & 2 & 1 & 2 & 2 & 2 & 2 & 2 & 3.623 & 3.100 \\
\hline DG-129 & 2 & 3 & 2 & 3 & 35.00 & 23.00 & 3.15 & 2 & 1 & 2 & 1 & 2. & l & 2 & 2.810 & 2.017 \\
\hline DG-130 & 3 & 2 & 4 & 1 & 45.00 & 22.60 & 5.35 & 1 & 2 & 2 & 2 & 1 & 1 & 2 & 3.957 & 4.777 \\
\hline DG-131 & 2 & 2 & 4 & 1 & 37.75 & 22.10 & 5.45 & 1 & 2 & 1 & 1 & 1 & 2 & 2 & 2.447 & 2.073 \\
\hline DG-132 & 3 & 3 & 4 & 1 & 43.50 & 22.95 & 5.35 & 2 & 2 & 2 & 2 & 2 & 1 & 2 & 4.877 & 5.793 \\
\hline DG-133 & 2 & 3 & 2 & 4 & 39.50 & 23.55 & 7.20 & 2 & 2 & 2 & 2 & 3 & 3 & 2 & 3.870 & 3.437 \\
\hline DG-134 & 2 & 3 & 4 & 1 & 32.75 & 20.00 & 5.40 & 2 & 2 & 2 & 1 & 4 & 1 & 2 & 3.770 & 6.843 \\
\hline DG-138 & 2 & 3 & 5 & 1 & 27.25 & 17.20 & 4.05 & 2 & 2 & 2 & 2 & 3 & 3 & 2 & 0.943 & 1.770 \\
\hline MANT & 3 & 2 & 4 & I & 44.00 & 22.75 & 6.60 & 2 & 2 & 2 & 2 & 4 & 1 & 2 & 3.910 & 4.010 \\
\hline
\end{tabular}

descritores de 1 a 14 média de uma repetição, descritores 15 e 16 média de 3 repetições. 
Tabela 2. Características das etnovariedades. (Continuação)

\begin{tabular}{|c|c|c|c|c|c|c|c|c|c|c|}
\hline ETV & 17 & 18 & 19 & 20 & 21 & 22 & 23 & 24 & 25 & 26 \\
\hline DG-38 & 0.540 & 3.527 & 1.253 & 834.6 & 271.1 & 30.200 & 24.923 & 6.690 & 5.950 & 15.487 \\
\hline DG-39 & 0.357 & 2.550 & 0.347 & 761.5 & 214.8 & 33.680 & 25.837 & 6.383 & 7.320 & 14.613 \\
\hline DG -40 & 0.417 & 2.373 & 0.263 & 942.1 & 127.9 & 35.813 & 24.170 & 5.857 & 7.357 & 18.457 \\
\hline DG-41 & 0.453 & 2.300 & 0.240 & 1131.9 & 215.2 & 30.297 & 23.327 & 7.280 & 6.580 & 14.340 \\
\hline DG -42 & 0.287 & 1.910 & 0.160 & 718.9 & 123.6 & 39.183 & 25.267 & 5.177 & 6.860 & 17.870 \\
\hline DG -43 & 0.313 & 2.463 & 0.537 & 1485.3 & 144.7 & 37.417 & 27.917 & 5.417 & 6.197 & 19.303 \\
\hline DG-44 & 0.363 & 2.627 & 0.480 & 1535.2 & 264.1 & 32.787 & 28.667 & 7.300 & 7.970 & 18.353 \\
\hline DG-45 & 0.390 & 2.747 & 0.670 & 1271.1 & 338.0 & 34.767 & 22.810 & 7.633 & 6.420 & 17.260 \\
\hline DG-46 & 0.353 & 2.200 & 0.347 & 1143.5 & 249.1 & 35.107 & 24.120 & 5.383 & 7.703 & 18.127 \\
\hline DG-47 & 0.330 & 3.337 & 0.613 & 1239.3 & 191.2 & 30.590 & 25.333 & 6.810 & 8.003 & 17.213 \\
\hline DG-48 & 0.430 & 2.467 & 0.680 & 1868.6 & 173.2 & 33.443 & 25.333 & 5.677 & 6.287 & 15.877 \\
\hline DG -49 & 0.420 & 2.580 & 0.343 & 1015.5 & 103.7 & 33.670 & 18.660 & 5.380 & 8.603 & 17.263 \\
\hline DG-50 & 0.270 & 2.030 & 0.220 & 1241.1 & 192.4 & 30.420 & 26.723 & 5.813 & 8.650 & 20.337 \\
\hline DG-51 & 0.293 & 2.517 & 0.457 & 1183.0 & 268.3 & 39.530 & 24.053 & 7.613 & 8.287 & 16.963 \\
\hline DG-52 & 0.327 & 1.997 & 0.297 & 1709.1 & 188.4 & 35.123 & 22.300 & 6.113 & 7.200 & 21.437 \\
\hline DG-54 & 0.230 & 2.343 & 0.103 & 1382.9 & 134.5 & 32.117 & 25.657 & 7.153 & 7.347 & 19.443 \\
\hline DG-55 & 0.430 & 2.587 & 0.660 & 901.4 & 119.8 & 36.580 & 25.350 & 7.267 & 7.903 & 19.537 \\
\hline DG-56 & 0.240 & 2.713 & 0.437 & 1210.2 & 154.2 & 35.400 & 23.670 & 5.713 & 6.087 & 18.623 \\
\hline DG-58 & 0.313 & 2.630 & 0.250 & 1176.4 & 233.8 & 33.253 & 22.313 & 5.977 & 6.770 & 17.557 \\
\hline DG-59 & 0.367 & 2.187 & 0.187 & 1095.5 & 179.5 & 32.740 & 23.523 & 6.653 & 9.500 & 17.870 \\
\hline DG-60 & 0.407 & 2.133 & 0.283 & 1656.2 & 167.4 & 33.477 & 25.433 & 4.987 & 6.737 & 17.237 \\
\hline DG-61 & 0.373 & 2.740 & 0.553 & 779.0 & 126.3 & 27.800 & 23.807 & 6.297 & 6.430 & 15.887 \\
\hline DG-62 & 0.323 & 2.430 & 0.243 & 1145.8 & 194.9 & 43.813 & 26.047 & 7.403 & 6.333 & 17.790 \\
\hline DG-65 & 0.553 & 3.083 & 1.420 & 393.8 & 108.6 & 36.610 & 25.230 & 6.373 & 7.183 & 18.870 \\
\hline DG-67 & 0.503 & 2.980 & 1.200 & 1113.9 & 346.6 & 33.000 & 26.470 & 6.607 & 7.467 & 16.663 \\
\hline DG-68 & 0.467 & 3.173 & 0.817 & 733.7 & 140.0 & 31.323 & 24.217 & 7.877 & 7.980 & 19.257 \\
\hline DG-69 & 0.483 & 2.233 & 0.283 & 1323.2 & 192.8 & 31.790 & 23.497 & 6.853 & 8.190 & 17.820 \\
\hline DG-70 & 0.467 & 2.243 & 0.427 & 2017.2 & 195.0 & 28.773 & 21.647 & 6.217 & 6.987 & 17.420 \\
\hline DG-71 & 0.323 & 2.000 & 0.137 & 1253.8 & 149.9 & 34.040 & 25.307 & 10.157 & 7.290 & 17.220 \\
\hline DG-73 & 0.480 & 3.140 & 0.970 & 1339.9 & 389.3 & 32.637 & 24.830 & 6.923 & 6.310 & 18.293 \\
\hline DG-111 & 0.443 & 3.050 & 1.010 & 1379.6 & 249.2 & 35.630 & 24.167 & 8.507 & 6.173 & 19.123 \\
\hline DG-112 & 0.280 & 2.580 & 0.333 & 1473.0 & 187.0 & 31.820 & 25.040 & 10.367 & 7.057 & 15.453 \\
\hline DG-113 & 0.430 & 2.590 & 0.773 & 856.0 & 96.3 & 34.630 & 25.207 & 5.670 & 6.747 & 16.983 \\
\hline DG-114 & 0.377 & 2.753 & 0.423 & 1537.3 & 149.5 & 36.460 & 25.600 & 6.970 & 5.520 & 18.240 \\
\hline DG-115 & 0.537 & 3.080 & 0.940 & 798.1 & 131.8 & 37.417 & 25.000 & 6.797 & 10.640 & 17.783 \\
\hline DG-116 & 0.387 & 2.830 & 0.710 & 1398.4 & 164.6 & 34.047 & 24.317 & 6.203 & 5.370 & 20.480 \\
\hline DG-117 & 0.383 & 3.530 & 1.197 & 893.2 & 314.5 & 32.687 & 27.627 & 7.250 & 8.287 & 23.103 \\
\hline DG-118 & 0.367 & 3.357 & 0.993 & 658.6 & 173.8 & 35.333 & 24.997 & 6.183 & 7.600 & 19.420 \\
\hline DG-119 & 0.377 & 2.887 & 0.820 & 724.1 & 153.0 & 33.190 & 24.763 & 6.247 & 8.140 & 16.843 \\
\hline DG-120 & 0.373 & 2.823 & 0.487 & 784.6 & 44.2 & 34.057 & 23.777 & 9.490 & 8.070 & 17.967 \\
\hline DG-121 & 0.347 & 1.893 & 0.227 & 1161.0 & 170.6 & 38.540 & 21.707 & 6.333 & 6.453 & 18.197 \\
\hline DG-122 & 0.550 & 2.387 & 0.380 & 639.2 & 119.4 & 40.293 & 25.313 & 6.310 & 6.773 & 15.190 \\
\hline DG-123 & 0.500 & 2.963 & 0.760 & 916.4 & 155.1 & 29.553 & 25.490 & 6.787 & 7.097 & 18.927 \\
\hline DG-124 & 0.483 & 3.120 & 1.177 & 1075.8 & 196.2 & 32.263 & 22.253 & 6.017 & 8.107 & 18.743 \\
\hline DG-125 & 0.467 & 3.113 & 0.763 & 1714.2 & 292.3 & 32.447 & 23.620 & 6.773 & 7.167 & 17.530 \\
\hline DG-126 & 0.630 & 3.043 & 1.620 & 706.2 & 117.4 & 41.197 & 25.353 & 6.990 & 10.057 & 17.283 \\
\hline DG-127 & 0.533 & 3.633 & 2.050 & 879.1 & 173.3 & 33.763 & 24.867 & 5.883 & 8.310 & 18.550 \\
\hline DG-128 & 0.550 & 3.357 & 1.423 & 751.9 & 160.4 & 33.913 & 23.903 & 7.470 & 8.730 & 18.043 \\
\hline DG-129 & 0.587 & 2.923 & 0.983 & 647.6 & 220.2 & 32.200 & 19.540 & 6.017 & 7.593 & 18.083 \\
\hline DG-130 & 0.460 & 3.217 & 1.600 & 787.3 & 266.6 & 30.863 & 24.933 & 9.240 & 10.873 & 17.533 \\
\hline DG-131 & 0.543 & 2.993 & 0.980 & 736.6 & 125.9 & 34.050 & 24.210 & 4.870 & 6.123 & 17.407 \\
\hline DG-132 & 0.453 & 3.267 & 2.010 & 1026.8 & 179.8 & 31.610 & 24.970 & 6.040 & 6.937 & 17.983 \\
\hline DG-133 & 0.530 & 2.850 & 1.340 & 1191.3 & 297.4 & 24.747 & 23.063 & 6.003 & 8.343 & 17.913 \\
\hline DG-134 & 0.357 & 3.217 & 1.457 & 1010.3 & 232.9 & 35.203 & 23.010 & 6.770 & 7.127 & 16.137 \\
\hline DG-138 & 0.343 & 2.647 & 0.240 & 1502.7 & 212.9 & 29.823 & 24.970 & 7.007 & 7.260 & 18.570 \\
\hline MANT & 0.500 & 3.177 & 1.323 & 1024.6 & 311.3 & 31.893 & 22.300 & 5.977 & 6.893 & 17.133 \\
\hline
\end{tabular}


Tabela 2. Caracteristicas das etnovariedades. (Continuação).

\begin{tabular}{|c|c|c|c|c|c|c|c|c|c|c|}
\hline ETV & 27 & 28 & 29 & 30 & 31 & 32 & 33 & 34 & 35 & 36 \\
\hline DG-38 & 20.187 & 68.793 & 8.447 & 6.557 & 45.573 & 1.890 & 35.490 & 104.843 & 9.783 & 53.370 \\
\hline DG-39 & 17.667 & 63.647 & 5.437 & 5.370 & 50.817 & 1.703 & 33.233 & 64.200 & 5.533 & 47.580 \\
\hline DG-40 & 15.787 & 61.643 & 5.387 & 4.197 & 56.473 & 1.400 & 30.040 & 53.557 & 6.020 & 30.140 \\
\hline$D G-41$ & 17.780 & 64.407 & 6.817 & 5.497 & 50.217 & 1.490 & 33.223 & 78.007 & 6.517 & 49.823 \\
\hline DG -42 & 18.940 & 65.217 & 5.710 & 5.127 & 52.690 & 1.583 & 32.557 & 282.427 & 28.130 & 18.680 \\
\hline DG -43 & 15.260 & 62.110 & 3.880 & 4.670 & 54.657 & 1.540 & 32.690 & 340.653 & 27.607 & 54.260 \\
\hline DG -44 & 9.950 & 59.960 & 3.867 & 3.800 & 56.740 & 1.123 & 31.933 & 294.843 & 29.963 & 89.450 \\
\hline DG-45 & 19.127 & 68.950 & 2.883 & 3.833 & 43.730 & 0.770 & 29.967 & 64.677 & 5.807 & 27.710 \\
\hline$D G-46$ & 14.997 & 66.487 & 5.087 & 5.280 & 52.273 & 1.797 & 33.053 & 84.243 & 8.977 & 47.753 \\
\hline DG-47 & 14.897 & 57.007 & 4.467 & 5.720 & 57.210 & 1.700 & 27.783 & 101.493 & 8.717 & 75.353 \\
\hline DG-48 & 17.820 & 64.753 & 7.210 & 6.400 & 50.707 & 1.190 & 32.120 & 136.223 & 11.780 & 31.297 \\
\hline DG-49 & 21.957 & 61.317 & 6.293 & 4.520 & 50.167 & 1.090 & 34.760 & 61.723 & 4.853 & 32.810 \\
\hline DG-50 & 11.253 & 66.483 & 4.950 & 3.457 & 57.927 & 0.997 & 29.650 & 64.863 & 5.093 & 22.633 \\
\hline DG-51 & 16.593 & 62.050 & 3.490 & 3.360 & 57.920 & 1.357 & 30.827 & 51.230 & 5.117 & 35.960 \\
\hline DG-52 & 15.130 & 64.593 & 5.487 & 5.510 & 55.420 & 1.607 & 29.183 & 54.433 & 5.090 & 16.057 \\
\hline DG-54 & 13.433 & 62.090 & 8.153 & 3.970 & 57.170 & 0.950 & 27.550 & 58.913 & 5.570 & 34.530 \\
\hline DG-55 & 13.083 & 68.910 & 5.940 & 5.093 & 51.707 & 1.470 & 32.853 & 117.730 & 11.473 & 49.627 \\
\hline DG-56 & 18.817 & 67.420 & 3.770 & 3.620 & 54.090 & 1.797 & 33.723 & 69.247 & 7.630 & 27.187 \\
\hline DG-58 & 19.307 & 60.117 & 4.287 & 4.780 & 53.4 & 1.693 & 32.333 & 65.973 & 6.853 & 11.580 \\
\hline DG-59 & 15.957 & 67.993 & 5.053 & 3.880 & 55.980 & 1.747 & 30.510 & 62.237 & 4.613 & 24.093 \\
\hline DG-60 & 17.377 & 63.040 & 3.307 & 3.580 & 60.620 & 1.237 & 29.490 & 181.240 & 17.033 & 26.377 \\
\hline DG-61 & 20.560 & 64.560 & 6.430 & 7.723 & 46.060 & 1.790 & 36.650 & 65.760 & 5.563 & 8.410 \\
\hline DG-62 & 14.840 & 64.080 & 5.967 & 5.380 & 54.073 & 1.420 & 30.137 & 101.970 & 8.210 & 20.763 \\
\hline DG-65 & & 64.083 & 4.713 & 5.603 & 47.687 & 1.923 & 37.140 & 78.343 & 6.790 & 19.740 \\
\hline DG-67 & 13.863 & 66.953 & 5.610 & 5.830 & 52.830 & 1.687 & 31.827 & 69.480 & 7.340 & 42.697 \\
\hline DG-68 & 13.603 & 66.543 & 4.640 & 4.367 & 50.683 & 1.793 & 35.537 & 45.677 & 3.990 & 11.803 \\
\hline DG-69 & 13.187 & 69.467 & 5.087 & 5.233 & 52.390 & 1.750 & 32.640 & 148.977 & 13.347 & 17.387 \\
\hline DG-70 & 18.317 & 61.740 & 5.317 & 4.613 & 51.873 & 1.653 & 33.733 & 89.893 & 7.867 & 26.470 \\
\hline DG-71 & 12.870 & 69.390 & 5.623 & 7.27 & 55.940 & 1.830 & 27.670 & 110.240 & 10.613 & 50.577 \\
\hline DG-73 & 17.840 & 63.937 & 5.010 & 5.203 & 53.677 & 1.187 & 32.070 & 290.787 & 22.557 & 49.297 \\
\hline DG-111 & 13.760 & 58.560 & 2.793 & 1.863 & 62.880 & 0.607 & 29.247 & 82.827 & 7.683 & 28.947 \\
\hline DG-112 & 13.827 & 56.147 & 5.200 & 4.933 & 54.7 & 1.290 & 31.513 & & 8.603 & 29.307 \\
\hline DG-113 & 18.227 & 56.830 & 3.73 & 3.667 & 54.540 & 1.827 & 32.940 & 95.737 & 7.930 & 19.630 \\
\hline DG-114 & 16.433 & 68.653 & 3.563 & 4.453 & 51.467 & 1.853 & 35.270 & 245.657 & 22.183 & 34.700 \\
\hline DG-115 & 9.440 & 66.133 & 3.960 & 6.263 & 54.123 & 1.283 & 31.940 & 200.890 & 19.050 & 25.707 \\
\hline DG-116 & 17.017 & 65.097 & 4.023 & 6.197 & 52.287 & 1.420 & 32.553 & 282.347 & 31.377 & 37.507 \\
\hline DG-117 & 7.193 & 66.453 & 5.637 & 5.400 & 49.397 & 1.817 & 35.520 & 195.393 & 19.840 & 17.367 \\
\hline DG-118 & 12.787 & 66.337 & 4.423 & 1.937 & 57.237 & 1.053 & 32.930 & 95.143 & 9.497 & 10.143 \\
\hline DG-119 & 17.227 & 61.820 & 6.363 & 3.453 & 52.663 & 1.367 & 34.223 & 107.850 & 10.553 & 20.467 \\
\hline DG-120 & 12.707 & 63.090 & 6.527 & 4.123 & 52.267 & 1.370 & 32.253 & 157.987 & 15.447 & 13.777 \\
\hline DG-121 & 19.203 & 59.350 & 5.757 & 5.813 & 51.113 & 1.970 & 32.500 & 204.477 & 19.213 & 39.050 \\
\hline DG-122 & 17.967 & 59.050 & 6.397 & 8.760 & 55.467 & 1.030 & 26.917 & 87.323 & 7.110 & 41.887 \\
\hline DG-123 & 14.213 & 55.247 & 3.253 & 3.680 & 56.030 & 1.547 & 33.170 & 60.033 & 6.417 & 23.853 \\
\hline DG-124 & 17.490 & 66.170 & 5.910 & 7.107 & 52.927 & 1.707 & 29.587 & 104.593 & 9.810 & 18.243 \\
\hline DG-125 & 18.077 & 60.437 & 3.957 & 6.587 & 54.750 & 1.407 & 31.480 & 91.453 & 9.333 & 22.410 \\
\hline DG-126 & 14.800 & 63.930 & 4.857 & 3.633 & 54.067 & 1.153 & 35.133 & 317.050 & 30.947 & 55.383 \\
\hline DG-127 & 19.307 & 60.670 & 5.237 & 6.043 & 51.887 & 1.517 & 32.667 & 87.323 & 7.430 & 15.913 \\
\hline DG-128 & 14.520 & 71.923 & 6.110 & 5.993 & 53.463 & 1.647 & 30.143 & 85.220 & 10.010 & 36.437 \\
\hline DG-129 & 13.740 & 62.103 & 4.680 & 6.787 & 52.487 & 1.667 & 31.687 & 86.413 & 8.257 & 40.827 \\
\hline DG-130 & 12.897 & 63.100 & 5.093 & 6.253 & 53.087 & 1.893 & 30.993 & 181.067 & 18.023 & 11.843 \\
\hline DG-131 & 19.867 & 69.827 & 5.950 & 7.183 & 49.820 & 1.777 & 32.353 & 73.247 & 6.543 & 8.907 \\
\hline DG-132 & 14.870 & & 4.410 & 4.547 & 53.327 & 1.447 & 33.393 & 99.967 & 9.000 & 18.110 \\
\hline DG-133 & 18.873 & 72.327 & 5.053 & 7.180 & 47.013 & 1.690 & 35.760 & 184.750 & 19.247 & 29.017 \\
\hline DG-134 & 17.157 & 66.350 & 5.803 & 6.650 & 55.860 & 1.443 & 37.873 & 280.517 & 25.790 & 32.130 \\
\hline DG-138 & 12.960 & 59.757 & 3.757 & 2.567 & 58.853 & 1.120 & 31.820 & 85.687 & 8.903 & 28.583 \\
\hline MANT & 11.953 & 64.370 & 4.617 & 3.293 & 54.053 & 1.813 & 33.653 & 116.547 & 13.203 & 9.503 \\
\hline
\end{tabular}


Tabela 2. Características das etnovariedades. (Continuação).

\begin{tabular}{|c|c|c|c|c|c|c|c|c|c|c|}
\hline ETV & 37 & 38 & 39 & 40 & 41 & 42 & 43 & 44 & 45 & 46 \\
\hline DG-38 & 4.583 & 64.020 & 56.413 & 2.477 & 89.447 & 0.963 & 2.697 & 2.527 & 1.810 & 57.843 \\
\hline DG-39 & 4.507 & 61.407 & 56.503 & 1.957 & 89.640 & 0.853 & 2.060 & 3.637 & 1.770 & 56.823 \\
\hline DG-40 & 3.980 & 55.760 & 59.587 & 2.270 & 88.537 & 0.827 & 2.797 & 4.147 & 1.337 & 61.983 \\
\hline$D G-11$ & 5.640 & 56.163 & 60.893 & 2.310 & 88.413 & 0.873 & 3.013 & 3.733 & 1.587 & 62.973 \\
\hline$D G-42$ & 2.160 & 57.103 & 59.283 & 2.393 & 88.810 & 0.740 & 2.090 & 3.810 & 1.620 & 60.040 \\
\hline DG-43 & 5.120 & 56.577 & 57.693 & 2.127 & 88.803 & 0.857 & 2.030 & 4.287 & 1.843 & 57.817 \\
\hline DG-44 & 7.807 & 57.590 & 62.593 & 2.620 & 88.617 & 0.910 & 2.230 & 3.627 & 1.540 & 62.390 \\
\hline DG-45 & 2.627 & 69.790 & 61.553 & 2.253 & 88.343 & 0.917 & 2.033 & 4.130 & 1.740 & 62.443 \\
\hline DG -46 & 5.723 & 60.567 & 67.587 & 4.123 & 84.577 & 0.767 & 3.053 & 5.543 & 1.893 & 67.407 \\
\hline DG -47 & 7.783 & 60.240 & 65.377 & 2.257 & 89.130 & 0.877 & 2.313 & 3.543 & 1.763 & 65.183 \\
\hline DG-48 & 4.080 & 63.243 & 62.640 & 2.847 & 87.063 & 0.943 & 2.587 & 4.633 & 1.857 & 63.753 \\
\hline DG-49 & 2.743 & 60.950 & 71.920 & 2.613 & 86.923 & 0.780 & 2.517 & 4.700 & 1.957 & 66.710 \\
\hline DG-50 & 1.723 & 55.620 & 64.907 & 2.527 & 88.393 & 0.720 & 2.253 & 4.250 & 1.723 & 65.537 \\
\hline DG-51 & 3.143 & 58.433 & 60.567 & 2.427 & 88.197 & 0.877 & 2.167 & 4.640 & 1.630 & 61.843 \\
\hline DG-52 & 1.360 & 58.067 & 62.800 & 2.710 & 88.383 & 0.730 & 2.160 & 4.113 & 1.697 & 64.110 \\
\hline DG-54 & 3.387 & 64.283 & 72.773 & 3.513 & 84.907 & 0.800 & 3.587 & 5.167 & 1.783 & 76.133 \\
\hline DG-55 & 4.963 & 64.163 & 63.683 & 3.193 & 86.430 & 0.857 & 3.427 & 4.123 & 1.920 & 65.553 \\
\hline DG-56 & 2.690 & 68.710 & 62.577 & 1.680 & 89.053 & 0.807 & 2.230 & 4.467 & 1.370 & 63.957 \\
\hline DG-58 & 1.233 & 61.853 & 71.713 & 1.973 & 87.467 & 0.720 & 2.540 & 5.210 & 1.830 & 72.263 \\
\hline DG-59 & 2.180 & 59.863 & 66.063 & 2.823 & 87.283 & 0.820 & 2.393 & 4.797 & 1.743 & 66.273 \\
\hline DG-60 & 2.143 & 55.377 & 65.120 & 3.067 & 86.977 & 0.940 & 2.603 & 4.853 & 1.383 & 66.080 \\
\hline DG-61 & 0.913 & 59.273 & 56.657 & 1.260 & 89.483 & 0.897 & 1.903 & 4.560 & 1.617 & 57.953 \\
\hline DG-62 & 1.850 & 65.140 & 67.737 & 1.870 & 88.457 & 0.917 & 2.230 & 3.603 & 1.670 & 67.343 \\
\hline DG-65 & 2.050 & 64.157 & 58.387 & 2.380 & 90.003 & 0.820 & 2.397 & 2.527 & 1.803 & 61.363 \\
\hline DG-67 & 3.667 & 65.593 & 58.903 & 1.773 & 90.640 & 0.803 & 1.747 & 3.103 & 1.753 & 59.997 \\
\hline DG-68 & 1.157 & 62.877 & 59.480 & 2.313 & 88.253 & 0.853 & 2.200 & 4.420 & 1.863 & 59.767 \\
\hline DG-69 & 1.503 & 64.903 & 65.033 & 2.403 & 87.833 & 0.820 & 2.457 & 4.167 & 1.797 & 64.610 \\
\hline DG-70 & 2.687 & 55.490 & 59.973 & 3.610 & 87.310 & 0.817 & 2.477 & 3.867 & 1.567 & 60.537 \\
\hline DG-71 & 4.943 & 63.520 & 75.293 & 5.307 & 79.430 & 0.860 & 4.733 & 7.697 & 1.713 & 75.257 \\
\hline DG-73 & 5.047 & 68.130 & 65.107 & 3.790 & 84.910 & 0.907 & 3.763 & 4.640 & 1.837 & 64.600 \\
\hline DG-111 & 1.980 & 55.990 & 59.780 & 2.250 & 89.647 & 0.907 & 1.327 & 3.810 & 1.907 & 59.313 \\
\hline DG-112 & 2.317 & 58.413 & 65.657 & 1.853 & 89.270 & 0.750 & 2.007 & 4.470 & 1.540 & 66.777 \\
\hline DG-113 & 1.647 & 59.600 & 56.687 & 3.127 & 88.343 & 0.720 & 1.973 & 4.123 & 1.683 & 58.643 \\
\hline DG-114 & 2.863 & 62.993 & 68.960 & 2.167 & 87.383 & 0.657 & 2.527 & 4.667 & 1.430 & 69.073 \\
\hline DG-115 & 2.540 & 65.777 & 62.703 & 3.390 & 85.687 & 0.920 & 2.577 & 5.473 & 1.807 & 64.247 \\
\hline DG-116 & 3.647 & 59.843 & 61.030 & 3.140 & 88.200 & 0.840 & 1.770 & 4.193 & 1.713 & 61.780 \\
\hline DG-117 & 1.723 & 65.893 & 59.070 & 2.810 & 88.670 & 0.797 & 2.427 & 3.430 & 1.770 & 59.467 \\
\hline DG-118 & 0.973 & 65.227 & 54.680 & 1.313 & 90.357 & 0.790 & 1.917 & 3.137 & 1.633 & 59.137 \\
\hline DG-119 & 2.527 & 60.220 & 56.773 & 2.850 & 88.927 & 0.857 & 2.227 & 3.207 & 1.743 & 58.190 \\
\hline DG-120 & 1.583 & 62.407 & 65.710 & 1.737 & 88.810 & 0.897 & 2.110 & 4.167 & 1.713 & 65.750 \\
\hline DG-121 & 3.053 & 58.447 & 62.283 & 2.163 & 88.010 & 0.843 & 2.137 & 4.807 & 1.923 & 62.753 \\
\hline DG-122 & 4.777 & 55.943 & 60.177 & 4.170 & 87.650 & 0.880 & 2.230 & 3.217 & 1.800 & 60.810 \\
\hline DG-123 & 2.350 & 64.460 & 62.277 & 2.877 & 87.497 & 0.903 & 2.453 & 4.253 & 1.800 & 61.767 \\
\hline DG-124 & 2.503 & 57.647 & 51.483 & 2.370 & 89.237 & 0.983 & 2.093 & 3.507 & 1.143 & 53.390 \\
\hline DG-125 & 2.250 & 60.170 & 61.373 & 2.360 & 88.103 & 0.907 & 2.400 & 4.303 & 1.897 & 62.377 \\
\hline DG-126 & 6.053 & 63.697 & 56.477 & 2.863 & 88.147 & 0.870 & 1.950 & 4.390 & 1.667 & 57.987 \\
\hline DG-127 & 1.150 & 62.040 & 57.503 & 3.457 & 88.907 & 0.793 & 1.793 & 3.167 & 1.787 & 59.567 \\
\hline DG-128 & 4.230 & 62.083 & 54.593 & 3.553 & 88.457 & 0.877 & 2.283 & 2.910 & 1.713 & 55.343 \\
\hline DG-129 & 3.110 & 62.423 & 60.993 & 2.897 & 88.437 & 0.943 & 2.670 & 3.420 & 1.490 & 60.607 \\
\hline DG-130 & 1.637 & 61.973 & 55.223 & 2.327 & 89.850 & 0.993 & 1.607 & 3.230 & 1.733 & 57.783 \\
\hline DG-131 & 1.150 & 61.043 & 55.300 & 3.633 & 89.240 & 0.933 & 1.780 & 2.633 & 1.713 & 56.123 \\
\hline DG-132 & 1.163 & 62.917 & 55.343 & 2.543 & 90.280 & 0.817 & 2.170 & 2.507 & 1.340 & 57.320 \\
\hline DG-133 & 2.577 & 61.067 & 61.077 & 2.160 & 88.857 & 0.833 & 2.330 & 4.203 & 1.563 & 62.313 \\
\hline DG-134 & 2.760 & 63.720 & 56.803 & 2.460 & 89.627 & 0.690 & 2.337 & 3.807 & 1.443 & 58.593 \\
\hline DG-138 & 2.613 & 55.797 & 69.787 & 2.827 & 86.177 & 0.920 & 2.853 & 5.123 & 1.963 & 70.910 \\
\hline MANT & 1.320 & 66.497 & 62.187 & 1.313 & 89.400 & 0.777 & 2.197 & 4.370 & 1.833 & 62.587 \\
\hline
\end{tabular}


Tabela 3. Média e freqüência dos estados para as variáveis discretas 1 a 4 e 8 a 14 .

\begin{tabular}{|c|c|c|c|c|c|c|c|c|c|c|c|}
\hline & 1 & 2 & 3 & 4 & 8 & 9 & 10 & 11 & 12 & 13 & 14 \\
\hline \multicolumn{12}{|l|}{ Reg 1} \\
\hline Média & 1,8 & 2,7 & 2,5 & 1,3 & 1,9 & 1,9 & 1,8 & 1,8 & 2,8 & 2,4 & 2,0 \\
\hline 1 & $36,67 \%$ & $0,00 \%$ & $10,00 \%$ & $83,33 \%$ & $6,67 \%$ & $6,67 \%$ & $16,67 \%$ & $20,00 \%$ & $6.67 \%$ & $16,67 \%$ & $0.00 \%$ \\
\hline 2 & $46,67 \%$ & $30,00 \%$ & $63,33 \%$ & $3,33 \%$ & $93.33 \%$ & $93,33 \%$ & $83.33 \%$ & $80.00 \%$ & $20.00 \%$ & $26.67 \%$ & $96.67 \%$ \\
\hline 3 & $16,67 \%$ & $70,00 \%$ & $0,00 \%$ & $10.00 \%$ & & & & $0,00 \%$ & $60.00 \%$ & $56.67 \%$ & $3,33 \%$ \\
\hline 4 & & & $23.33 \%$ & $3.33 \%$ & & & & $0.00 \%$ & $10.00 \%$ & $0.00 \%$ & \\
\hline 5 & & & $3.33 \%$ & & & & & & $3.33 \%$ & $0.00 \%$ & \\
\hline
\end{tabular}

Reg 2

$\begin{array}{llllllllllll}\text { Média } & 2,1 & 2,6 & \mathbf{3 , 4} & \mathbf{1 , 2} & \mathbf{1 , 7} & \mathbf{2 , 0} & \mathbf{1 , 7} & \mathbf{1 , 7} & \mathbf{2 , 8} & \mathbf{2 , 4} & \mathbf{2 , 0}\end{array}$ $\begin{array}{llllllllllll}1 & 25,00 \% & 0,00 \% & 12,50 \% & 87,50 \% & 31,25 \% & 0,00 \% & 31.25 \% & 37,50 \% & 6,25 \% & 25,00 \% & 0,00 \%\end{array}$ $2 \quad 43,75 \% \quad 37,50 \% \quad 25.00 \% \quad 6,25 \% \quad 68,75 \% \quad 100,00 \quad 68,75 \% \quad 56.25 \% \quad 25.00 \% \quad 12.50 \% \quad 100.00$

\begin{tabular}{|c|c|c|c|}
\hline \multirow{2}{*}{$\begin{array}{lll}3 & 31,25 \% & 62,50 \% \\
4 & \end{array}$} & $0,00 \% \quad 6,25 \%$ & $6,25 \%$ & $56.25 \%$ \\
\hline & $31,25 \%$ & $0,00 \%$ & $6.25 \%$ \\
\hline 5 & $31.25 \%$ & & $6.25 \%$ \\
\hline
\end{tabular}

$\operatorname{Reg} 3$

$\begin{array}{llllllllllll}\text { Média } & 2,2 & 2,4 & 3,7 & 1,7 & 1,8 & 1,8 & 1,9 & 1,6 & 2,2 & 1,4 & 2,0\end{array}$ $\begin{array}{llllllllllll}1 & 11,11 \% & 0,00 \% & 0,00 \% & 66,67 \% & 22,22 \% & 22,22 \% & 11,11 \% & 44,44 \% & 33.33 \% & 66.67 \% & 0,00 \%\end{array}$ $2 \quad \begin{array}{lllllllllll}55,56 \% & 55,56 \% & 22,22 \% & 11,11 \% & 77,78 \% & 77,78 \% & 88.89 \% & 55.56 \% & 33.33 \% & 22.22 \% & 100.00\end{array}$

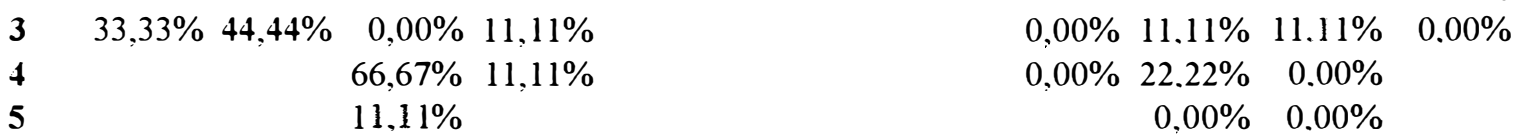

\begin{tabular}{|c|c|c|c|c|c|c|c|c|c|c|c|}
\hline \multicolumn{12}{|l|}{ Testem } \\
\hline Mant & 3 & 2 & 4 & 1 & 2 & 2 & 2 & 2 & 4 & 1 & 2 \\
\hline \multicolumn{12}{|l|}{ Geral } \\
\hline Média & 2,0 & 2,6 & 3,0 & 1,3 & 1,8 & 1,9 & 1,8 & 1,7 & 2,8 & 2,2 & 2,0 \\
\hline 1 & $28,57 \%$ & $0,00 \%$ & $8,93 \%$ & $82,14 \%$ & $16,07 \%$ & $7,14 \%$ & $19,64 \%$ & $28,57 \%$ & $10.71 \%$ & $28.57 \%$ & $0,00 \%$ \\
\hline 2 & $46,43 \%$ & $37,50 \%$ & $44,64 \%$ & $5,36 \%$ & $83,93 \%$ & $92.86 \%$ & $80.36 \%$ & $69,64 \%$ & $23.21 \%$ & $21.43 \%$ & $98,21 \%$ \\
\hline 3 & $25,00 \%$ & $62,50 \%$ & $0,00 \%$ & $8,93 \%$ & & & & $1,79 \%$ & $50.00 \%$ & $50.00 \%$ & $1,79 \%$ \\
\hline 4 & & & $33,93 \%$ & $3,57 \%$ & & & & $0,00 \%$ & $12.50 \%$ & $0.00 \%$ & \\
\hline 5 & & & $12,50 \%$ & & & & & & $3.57 \%$ & $0.00 \%$ & \\
\hline
\end{tabular}

Região 1: Rio Negro - Bacia Amazônica Região 2: Rio Solimões - Bacia Amazônica Região 3: Litoral sul - SP 
Tabela 4.1. Média, desvio padrão e amplitude, por região e geral para as variáveis 5 a 7 e 15 a 23.

\begin{tabular}{|c|c|c|c|c|c|c|c|c|c|c|c|c|}
\hline & 5 & 6 & 7 & 15 & 16 & 17 & 18 & 19 & 20 & 21 & 22 & 23 \\
\hline \multicolumn{13}{|l|}{ Região 1} \\
\hline Média & 29.01 & 19,91 & 4,72 & 1.497 & 2,284 & 0,383 & 2,541 & 0.496 & 1186.8 & 196,6 & 33,846 & 24.548 \\
\hline Min & 21.75 & 15,45 & 2.00 & 0.407 & 0,867 & 0,230 & 1.910 & 0.103 & 393.8 & 103.7 & 27,800 & 18.660 \\
\hline Max & 39.00 & 28.85 & 6.95 & 3.790 & 4,387 & 0.553 & 3.527 & 1.420 & 2017.2 & 389.3 & 43.813 & 28.667 \\
\hline Desv Pad & 5,09 & 3,49 & 1,10 & 0.913 & 0.980 & 0,086 & 0.414 & 0.341 & 355,8 & 72.5 & 3,362 & 1.931 \\
\hline \multicolumn{13}{|l|}{ Região 2} \\
\hline Média & 28,08 & 20,18 & 4,48 & 2,010 & 2,827 & 0,415 & 2,850 & 0,702 & 1094.5 & 175,6 & 34.262 & 24,616 \\
\hline Min & 18,75 & 16,45 & 1,35 & 0,690 & 0,917 & 0,280 & 1,893 & 0,227 & 639,2 & 44,2 & 29,553 & 21,707 \\
\hline Max & 36,00 & 26,00 & 6,45 & 3.310 & 5,343 & 0,550 & 3,530 & 1,197 & 1714,2 & 314,5 & 40,293 & 27,627 \\
\hline Desv Pad & 5,35 & 2,79 & 1,40 & 0,781 & 1,064 & 0,075 & 0,391 & 0,320 & 357,4 & 68,6 & 2,960 & 1,373 \\
\hline \multicolumn{13}{|l|}{ Região 3} \\
\hline Média & 36,12 & 21,63 & 4,91 & 3,897 & 3,954 & 0,516 & 3,167 & 1,496 & 859,7 & 197,1 & 33,061 & 23,761 \\
\hline Min & 25,25 & 17,50 & 2,25 & 2,447 & 2,017 & 0,357 & 2,850 & 0,980 & 647.6 & 117.4 & 24.747 & 19.540 \\
\hline Max & 45,00 & 23,55 & 7,20 & 5,493 & 6,843 & 0,630 & 3,633 & 2,050 & 1191.3 & 297,4 & 41,197 & 25,353 \\
\hline Desv Pad & 6,08 & 1,94 & 1,44 & 0,935 & 1.687 & 0,081 & 0,243 & 0,380 & 180.8 & 61,6 & 4,327 & 1,792 \\
\hline \multicolumn{13}{|c|}{ Testemunha } \\
\hline Mant & 44,00 & 22,75 & 6,60 & 3.910 & 4,010 & 0,500 & 3,177 & 1,323 & 1024,6 & 311,3 & 31,893 & 22,300 \\
\hline Média & 30,16 & 20,32 & 4,72 & 2.072 & 2,738 & 0,416 & 2,741 & 0,730 & 1105,0 & 192,7 & 33,804 & 24.401 \\
\hline Min & 18,75 & 15,45 & 1,35 & 0,407 & 0,867 & 0,230 & 1,893 & 0,103 & 393,8 & 44.2 & 24,747 & 18,660 \\
\hline Max & 45,00 & 28,85 & 7,20 & 5.493 & 6.843 & 0,630 & 3,633 & 2,050 & 2017,2 & 389,3 & 43,813 & 28,667 \\
\hline Desv Pad & 6,17 & 3,10 & 1.25 & 1,233 & 1,271 & 0,093 & 0,446 & 0,493 & 346,4 & 70,4 & 3,360 & 1,766 \\
\hline
\end{tabular}

Região 1: Rio Negro - Bacia Amazônica

Região 2: Rio Solimões - Bacia Amazônica

Região 3: Litoral sul - SP 
Tabela 4.2. Média, desvio padrão e amplitude, por região e geral para as variáveis 24 a 35 .

\begin{tabular}{|c|c|c|c|c|c|c|c|c|c|c|c|c|}
\hline ETV & 24 & 25 & 26 & 27 & 28 & 29 & 30 & 31 & 32 & 33 & 34 & 35 \\
\hline \multicolumn{13}{|l|}{ Região 1} \\
\hline Média & 6.566 & 7,263 & 17,746 & 16,221 & 64,591 & 5,277 & 4,982 & 53,026 & 1.5053 & 32.012 & 2113.129 & 10,281 \\
\hline Min & 4,987 & 5,950 & 14.340 & 9,950 & 57,007 & 2,883 & 3,360 & 43,730 & 0.7702 & 27.550 & 45,677 & 3.990 \\
\hline Max & 10,157 & 9,500 & 21,437 & 21,957 & 69.467 & 8,447 & 7.723 & 60,620 & 1.9233 & 37.140 & 340.653 & 29.963 \\
\hline Desv Pad & 1,045 & 0,880 & 1,567 & 2,910 & 3,153 & 1.312 & 1,102 & 3,937 & 0.311 & 2,517 & 81,909 & 7.360 \\
\hline \multicolumn{13}{|l|}{ Região 2} \\
\hline Média & 7,057 & 7,279 & 18,285 & 14,908 & 61,821 & 4,704 & 4,800 & 54,420 & 1,4173 & 32,116 & 137,055 & 13,309 \\
\hline Min & 5,670 & 5,370 & 15,190 & 7,193 & 55,247 & 2,793 & 1,863 & 49,397 & 0,6072 & 26,917 & 60,033 & 6,417 \\
\hline Max & 10,367 & 10,640 & 23,103 & 19,203 & 68,653 & 6,527 & 8,760 & 62,880 & 1,9703 & 35,520 & 282,347 & 31,377 \\
\hline Desv Pad & 1,303 & 1,258 & 1,880 & 3,398 & 4,237 & 1,243 & 1,940 & 3,292 & 0,364 & 2,181 & 67,592 & 7.111 \\
\hline \multicolumn{13}{|l|}{ Região 3} \\
\hline Média & 6,587 & 8,233 & 17,659 & 16,226 & 66,149 & 5,244 & 6,030 & 52,335 & 1,5823 & 33,334 & 155,062 & 15,027 \\
\hline Min & 4,870 & 6,123 & 16,137 & 12,897 & 60,670 & 4,410 & 3,633 & 47,013 & 1,1533 & 30,143 & 73,247 & 6,543 \\
\hline Max & 9,240 & 10,873 & 18,550 & 19,867 & 72,327 & 6,110 & 7,183 & 55,860 & 1.8933 & 37.873 & 317,050 & 30,947 \\
\hline Desv Pad & 1,246 & 1,514 & 0,692 & 2,614 & 4,283 & 0,590 & 1,204 & 2,577 & 0,219 & 2,488 & 91,818 & 8,896 \\
\hline \multicolumn{13}{|c|}{ Testemunha } \\
\hline Mant & 5,977 & 6,893 & 17,133 & 11,950 & 64,370 & 4,617 & 3,293 & 54,053 & 1.8133 & 33.653 & 116.547 & 13.203 \\
\hline Média & 6,699 & 7,417 & 17,875 & 15,762 & 64,046 & 5,096 & 5,068 & 53,331 & 1,4983 & 32,284 & 126,765 & 11,961 \\
\hline Min & 4,870 & 5,370 & 14,340 & 7,193 & 55,247 & 2,793 & 1,863 & 43,730 & 0,6072 & 26.917 & 45,677 & 3,990 \\
\hline Max & 10,367 & 10,8732 & 23,103 & $21,957^{\circ}$ & 72,327 & 8,447 & 8,760 & 62,880 & 1,9703 & 37,873 & 340,653 & 31,377 \\
\hline Desv Pad & 1,151 & 1,143 & 1,550 & 3,040 & 3,890 & 1,204 & 1.453 & 3,558 & 0.315 & 2,408 & 79,214 & 7,583 \\
\hline
\end{tabular}

Região 1: Rio Negro - Bacia Amazônica

Região 2: Rio Solimões - Bacia Amazônica

Região 3: Litoral sul - SP 
Tabela 4.3. Média, desvio padrão e amplitude, por região e geral para as variáveis 36 a 46.

\begin{tabular}{|c|c|c|c|c|c|c|c|c|c|c|c|}
\hline ETV & 36 & 37 & 38 & 39 & 40 & 41 & 42 & 43 & 44 & 45 & 46 \\
\hline \multicolumn{12}{|l|}{ Região 1} \\
\hline Média & 35.114 & 3,446 & 61.295 & 63.294 & 2.629 & 87.724 & 0,842 & 2,556 & 4,284 & 1,714 & 63.951 \\
\hline Min & 8,410 & 0,913 & 55,377 & 56,413 & 1,260 & 79,430 & 0,720 & 1.747 & 2,527 & 1,337 & 56,823 \\
\hline Max & 89.450 & 7.807 & 69,790 & 75.293 & 5.307 & 90,640 & 0,963 & 4,733 & 7,697 & 1.957 & 76.133 \\
\hline Desv Pad & 18,849 & 1,861 & 4,162 & 5.008 & 0,813 & 2,134 & 0,067 & 0,633 & 0,954 & 0.158 & 4,684 \\
\hline \multicolumn{12}{|l|}{ Região 2} \\
\hline Média & 25,724 & 2,459 & 60,552 & 61.152 & 2,588 & 88,248 & 0,848 & 2,189 & 4,118 & 1,717 & 62,149 \\
\hline Min & 10,143 & 0,973 & 55,797 & 51,483 & 1,313 & 85,687 & 0,657 & 1,327 & 3,137 & 1,143 & 53,390 \\
\hline Max & 41,887 & 4,777 & 65,893 & 69,787 & 4,170 & 90,357 & 0,983 & 2,853 & 5.473 & 1,963 & 70,910 \\
\hline Desv Pad & 9,238 & 0,888 & 3,523 & 4,921 & 0,705 & 1,211 & 0,086 & 0,362 & 0,700 & 0,208 & 4,434 \\
\hline \multicolumn{12}{|l|}{ Região 3} \\
\hline Média & 27,619 & 2,648 & 62,329 & 57,035 & 2,877 & 89,089 & 0,861 & 2,102 & 3.363 & 1,605 & 58,404 \\
\hline Min & 8,907 & 1,150 & 61,043 & 54,593 & 2,160 & 88,147 & 0,690 & 1,607 & 2.507 & 1,340 & 55,343 \\
\hline Max & 55,383 & 6,053 & 63,720 & 61,077 & 3,633 & 90,280 & 0,993 & 2,670 & 4,390 & 1.787 & 62,313 \\
\hline Desv Pad & 15,296 & 1,660 & 0,980 & 2,442 & 0,555 & 0,717 & 0,091 & 0,342 & 0,660 & 0.153 & 2,175 \\
\hline \multicolumn{12}{|c|}{ Testemunha } \\
\hline Mant & 9,503 & 1,320 & 66,497 & 62,187 & 1,313 & 89,400 & 0,777 & 2,197 & 4.370 & 1,833 & 62,587 \\
\hline Média & 30,769 & 2,998 & 61,342 & 61,656 & 2,634 & 88,123 & 0,846 & 2,372 & 4,090 & 1,699 & 62,521 \\
\hline Min & 8,410 & 0,913 & 55,377 & 51,483 & 1,260 & 79,430 & 0,657 & 1,327 & 2,507 & 1.143 & 53,390 \\
\hline Max & 89,450 & 7,807 & 69,790 & 75,293 & 5,307 & 90,640 & 0,993 & 4,733 & 7,697 & 1,963 & 76,133 \\
\hline Desv Pad & 16,498 & 1,645 & 3,672 & 5,073 & 0,756 & 1,775 & 0,076 & 0,552 & 0.886 & 0.174 & 4,642 \\
\hline
\end{tabular}

Região 1: Rio Negro - Bacia Amazônica

Região 2: Rio Solimões - Bacia Amazônica

Região 3: Litoral sul -

SP 
Tabela 5.1. Quadrados médios da análise de variância e suas respectivas significâncias pelo teste $F$, para os descritores 15 a 22 .

\begin{tabular}{|c|c|c|c|c|c|c|c|c|c|c|}
\hline F.V. & GL & & 15 & 16 & 17 & 18 & 19 & 20 & 21 & 22 \\
\hline Etnovarariedades & 55 & $\mathrm{QM}_{11}$ & $4.563^{*}$ & $4,846^{\circ}$ & $0,026^{\circ .}$ & $0,644^{* *}$ & $0.728^{* *}$ & $359976,9^{* *}$ & $14885.6^{*}$ & $33.872^{\text {ns }}$ \\
\hline Regiões (A) & 2 & $\mathrm{QM}_{10}$ & $65.002^{* *}$ & $31,871^{* *}$ & $0,191^{\mathrm{ns}}$ & $5,174^{*}$ & $10.892^{* *}$ & $1089260.9^{n s}$ & $11415.7^{\mathrm{ns}}$ & $16.205^{\text {ns }}$ \\
\hline Roças/A & 14 & $\mathrm{QM}_{9}$ & $3.809^{*}$ & $4,201^{\text {ns }}$ & $0,031^{\mathrm{ns}}$ & $0,486^{\mathrm{ns}}$ & $0.600^{*}$ & $505091.1^{\mathrm{ns}}$ & $15795.7^{1 \mathrm{ng}}$ & $24.690^{\text {ns }}$ \\
\hline Etnovar/R/A & 39 & $\mathrm{QM}_{8}$ & $1.735^{* *}$ & $3,693^{\circ *}$ & $0,015^{*}$ & $0,468^{* *}$ & $0.254^{* *}$ & $270485.6^{\mathrm{ns}}$ & $14736.9^{*}$ & $38.075^{\circ}$ \\
\hline Roças/Al & 6 & $\mathrm{QM}_{7}$ & $6,025^{*}$ & $2,717^{\mathrm{ns}}$ & $0,052^{*}$ & $0,767^{\text {ns }}$ & $0,948^{*}$ & $629924.6^{\mathrm{ns}}$ & $11333,9^{\mathrm{ns}}$ & $23,750^{\mathrm{ns}}$ \\
\hline Etnovar/R/Al & 23 & $\mathrm{QM}_{6}$ & $1,581^{* *}$ & $2,922^{*}$ & $0,014^{*}$ & $0,503^{*}$ & $0,193^{*}$ & $314567,9^{\circ}$ & 16939,0 & $36,551^{\mathrm{ns}}$ \\
\hline Roças/A2 & 3 & $\mathrm{QM}_{5}$ & $1,012^{n s}$ & $3,450^{\mathrm{ns}}$ & $0,011^{\mathrm{ns}}$ & $0,619^{\mathrm{ns}}$ & $0,109^{n s}$ & $849288,7^{\text {ns }}$ & $24301,6^{\mathrm{ns}}$ & $5.555^{\text {ns }}$ \\
\hline Etnovar/R/A2 & 12 & $\mathrm{QM}_{4}$ & $2,037^{* *}$ & $3,384^{\circ *}$ & $0,018^{* *}$ & $0,463^{*}$ & $0,357^{* *}$ & $266642,0^{\text {ns }}$ & $11593.3^{\mathrm{ns}}$ & $31,477^{\text {ns }}$ \\
\hline Roças/A3 & 5 & $\mathrm{QM}_{3}$ & $2,828^{\text {ns }}$ & $6,431^{\mathrm{ns}}$ & $0,018^{\mathrm{ns}}$ & $0,071^{\text {ns }}$ & $0,478^{\text {ns }}$ & $148772.1^{\mathrm{ns}}$ & $16046,3^{\text {ns }}$ & $37,299^{\mathrm{ns}}$ \\
\hline Etnovar/R/A3 & 4 & $\mathrm{QM}_{2}$ & $1,712^{*}$ & $9,048^{* *}$ & $0,018^{* *}$ & $0,285^{*}$ & $0.291^{* *}$ & $28542.5^{\mathrm{ns}}$ & $11505.3^{\text {ns }}$ & 66,633 \\
\hline Resíduo & 110 & $\mathrm{QM}_{1}$ & 0,510 & 0,942 & 0,004 & 0,071 & 0,071 & 187525.6 & 6401.8 & 23,658 \\
\hline $\mathrm{CV}_{\mathrm{e}}(\%)$ & & & 34,46 & 35,45 & 14,76 & 10,07 & 36,35 & 39,19 & 41.51 & 14.38 \\
\hline
\end{tabular}

\section{A: Regiões, efeito aleatório}

A1: Rio Negro - Bacia Amazônica

A2: Rio Solimões - Bacia Amazônica

A3: Litoral sul - SP

R: Roça, efeito aleatório

$\mathrm{V}$ : etnovariedades, efeito aleatório

ns. Teste $\mathrm{F}$, não significativo ao $5 \%$ de probabilidade

* Teste $\mathrm{F}$, significativo ao nível de $5 \%$ de probabilidade

** Teste F, significativo ao nível de $1 \%$ de probabilidade 
Tabela 5.2. Quadrados médios da análise de variância e suas respectivas significâncias pelo teste $F$, para os descritores 23 a 31 .

\begin{tabular}{|c|c|c|c|c|c|c|c|c|c|c|}
\hline F.V. & GL & & 23 & 24 & 25 & 26 & 28 & 29 & 30 & 31 \\
\hline Etnovarariedades & 55 & $\mathrm{QM}_{11}$ & $9,358^{* *}$ & $3,971^{* *}$ & $3,917^{* *}$ & $7,212^{* *}$ & $45,408^{* *}$ & $4,348^{* *}$ & $6,332 *$ & $37,982^{* *}$ \\
\hline Regiões (A) & 2 & $\mathrm{QM}_{10}$ & $11.341^{\mathrm{ns}}$ & $4.317^{\mathrm{ns}}$ & $8.491^{\text {ns }}$ & $5,852^{\mathrm{ns}}$ & $187.822 *$ & $5.283^{\mathrm{ns}}$ & $9,164^{\mathrm{ns}}$ & $42.842^{\mathrm{ns}}$ \\
\hline Roças/A & 14 & $\mathrm{QM}_{9}$ & $8,753^{\text {ns }}$ & $2,621^{\mathrm{ns}}$ & $3,164^{n s}$ & $8,890^{n s}$ & $35,513^{\mathrm{ns}}$ & $4,166^{13}$ & $7,632^{\mathrm{ns}}$ & $26,619^{n s}$ \\
\hline Etnovar/R/A & 39 & $\mathrm{QM}_{8}$ & $9,474^{* *}$ & $4,438^{* *}$ & $3,953^{* *}$ & $6,679^{* *}$ & $41,657^{* *}$ & $4,365^{*}$ & $5,721^{* *}$ & $41,955^{* *}$ \\
\hline Roças/Al & 6 & $\mathrm{QM}_{7}$ & $7,700^{\mathrm{ns}}$ & $3,650^{\mathrm{ns}}$ & $2,024^{\text {ns }}$ & $10,696^{\mathrm{ns}}$ & $23,091^{\mathrm{ns}}$ & $3,915^{\mathrm{ns}}$ & $4,949^{\mathrm{ns}}$ & $49,453^{\text {ns }}$ \\
\hline Etnovar/R/Al & 23 & $\mathrm{QM}_{6}$ & $12,093^{* *}$ & $3,180^{* *}$ & $2,403^{* *}$ & $6,497^{* *}$ & $31,588^{*}$ & $5,485^{* *}$ & $3,301^{* *}$ & $45,724^{* *}$ \\
\hline Roças/A2 & 3 & $\mathrm{QM}_{\mathrm{s}}$ & $7,742^{\mathrm{ns}}$ & $3,683^{\mathrm{ns}}$ & $4,698^{\mathrm{ns}}$ & $18,403^{\text {ns }}$ & $63,954^{\text {ns }}$ & $10,218^{\text {ns }}$ & $11,167^{\mathrm{ns}}$ & $14,996^{\mathrm{ns}}$ \\
\hline Etnovar/R/A2 & 12 & $\mathrm{QM}_{4}$ & $5,136^{\mathrm{ns}}$ & $5,449^{* *}$ & $4,694^{* *}$ & $8,657^{* *}$ & $51,338^{* *}$ & $3,236^{* *}$ & $11,316^{* *}$ & $36,886^{* *}$ \\
\hline Roças/A3 & 5 & $\mathrm{QM}_{3}$ & $10,622^{\mathrm{ns}}$ & $0,748^{\mathrm{ns}}$ & $3,449^{\text {ns }}$ & $1,014^{\mathrm{ns}}$ & $33,356^{\mathrm{ns}}$ & $0,837^{\mathrm{ns}}$ & $8,732^{\mathrm{ns}}$ & $5.072^{\mathrm{ns}}$ \\
\hline Etnovar/R/A3 & 4 & $\mathrm{QM}_{2}$ & $7,425^{\mathrm{ns}}$ & $8,633^{* *}$ & $10,645^{m *}$ & $1,792^{\mathrm{ns}}$ & $70,511^{* *}$ & $1,307^{* *}$ & $2,844^{* *}$ & $35,490 *$ \\
\hline Resíduo & 110 & $\mathrm{QM}_{1}$ & 4,278 & 1,092 & 0,889 & 0,890 & 19,455 & 0,094 & 0,076 & 0.432 \\
\hline $\mathrm{CV}_{\mathrm{e}}(\%)$ & & & 8,48 & 15,60 & 12,71 & 5,28 & 6,89 & 6,02 & 5,42 & 1,23 \\
\hline
\end{tabular}

A: Regiões, efeito aleatório

Al: Rio Negro - Bacia Amazônica

A2: Rio Solimões - Bacia Amazônica

A3: Litoral sul - SP

R: Roça, efeito aleatório

$\mathrm{V}$ : etnovariedades, efeito aleatório

ns. Teste $F$, não significativo ao $5 \%$ de probabilidade

* Teste $\mathrm{F}$, significativo ao nivel de $5 \%$ de probabilidade

${ }^{* *}$. Teste $\mathrm{F}$, significativo ao nível de $1 \%$ de probabilidade 
Tabela 5.3. Quadrados médios da análise de variância e suas respectivas significâncias pelo teste $F$, para os descritores 32 a 39.

\begin{tabular}{|c|c|c|c|c|c|c|c|c|c|c|}
\hline F.V. & GL & & 32 & 33 & 34 & 35 & 36 & 37 & 38 & 39 \\
\hline Etnovariedades & 55 & $\mathrm{QM}_{11}$ & $0,297^{*}$ & $17,398^{\circ *}$ & $18824.7^{\circ}$ & $172,486^{*}$ & $816,56^{\circ}$ & $8.119^{*}$ & $40,455^{\circ}$ & $77.195^{\circ}$ \\
\hline Regiões (A) & 2 & $\mathrm{QM}_{10}$ & $0,332^{\mathrm{ns}}$ & $21.542^{\mathrm{ns}}$ & $19871.2^{\mathrm{ns}}$ & $295.300^{\mathrm{ns}}$ & $1829.75^{\text {ns }}$ & $19.517^{\mathrm{ns}}$ & $44.657^{\mathrm{ns}}$ & $379,708^{n s}$ \\
\hline Roças/A & 14 & $\mathrm{QM}_{9}$ & $0,255^{\mathrm{ns}}$ & $19,306^{\mathrm{ns}}$ & $21440,9^{n s}$ & $193,100^{\mathrm{ns}}$ & $1143,66^{\mathrm{ns}}$ & $13,906^{\circ}$ & $28.117^{\mathrm{ns}}$ & $78.378^{\text {ns }}$ \\
\hline Etnovar/R/A & 39 & $\mathrm{QM}_{8}$ & $0,311^{* *}$ & $16,501^{* *}$ & $17831.8^{*}$ & $158,799^{* *}$ & $647,18^{* *}$ & $5,457^{\circ *}$ & $44,668^{\circ}$ & $61.256^{*}$ \\
\hline Roças/A1 & 6 & $\mathrm{QM}_{7}$ & $0,395^{\text {ns }}$ & $20,592^{\mathrm{ns}}$ & $29021,9^{n s}$ & $241,783^{\mathrm{ns}}$ & $1957,21^{\text {ns }}$ & $26,458^{\circ \cdot}$ & $42,157^{\mathrm{ns}}$ & $151,050^{*}$ \\
\hline Etnovar/R/Al & 23 & $\mathrm{QM}_{6}$ & $0,263^{* *}$ & $18,584^{* *}$ & $17806,7^{* *}$ & $141,810^{*-}$ & $833,31^{*=}$ & $6,193^{* *}$ & $54,541^{* *}$ & $55,455^{* *}$ \\
\hline Roças/A2 & 3 & $\mathrm{QM}_{5}$ & $0,073^{\mathrm{ns}}$ & $6,697^{\text {ns }}$ & $10019,8^{\text {ns }}$ & $146,659^{n s}$ & $53,225^{\mathrm{ns}}$ & $1,129^{n s}$ & $28,976^{\mathrm{ns}}$ & $22,218^{\mathrm{ns}}$ \\
\hline Etnovar/R/A2 & 12 & $\mathrm{QM}_{4}$ & $0,479^{* *}$ & $16,160^{* *}$ & $14627,4^{*}$ & $152,956^{* *}$ & $306,737^{\circ}$ & $2.672^{\circ}$ & $39.288^{\text {ns }}$ & $85,259^{\circ}$ \\
\hline Roças/A3 & 5 & $\mathrm{QM}_{3}$ & $0,197^{\text {ns }}$ & $25,328^{\mathrm{ns}}$ & $19196,3^{\text {ns }}$ & $162,431^{\mathrm{ns}}$ & $821,658^{\mathrm{ns}}$ & $6,509^{n s}$ & $10.755^{\mathrm{ns}}$ & $24,870^{\mathrm{ns}}$ \\
\hline Etnovar/R/A3 & 4 & $\mathrm{QM}_{2}$ & $0,078^{\mathrm{ns}}$ & $5,543^{\mathrm{ns}}$ & $27589,6^{\circ}$ & $274,017^{\circ}$ & $598,301^{* *}$ & $9.588^{\circ \bullet}$ & $4.037^{\mathrm{ns}}$ & $22,605^{\text {ns }}$ \\
\hline Resíduo & 110 & $\mathrm{QM}_{1}$ & 0,032 & 5,696 & 267,193 & 2,503 & 40,466 & 0,659 & 17.091 & 12,728 \\
\hline$C V_{e}(\%)$ & & & 12,01 & 7,39 & 12,89 & 13,23 & 20.67 & 27,08 & 6.73 & 5.79 \\
\hline
\end{tabular}

A: Regiões, efeito aleatório

Al: Rio Negro - Bacia Amazônica

A2: Rio Solimões - Bacia Amazônica

A3: Litoral sul - SP

R: Roça, efeito aleatório

$\mathrm{V}$ : etnovariedades, efeito aleatório

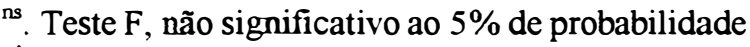

* Teste F, significativo ao nivel de $5 \%$ de probabilidade

${ }^{* *}$. Teste F, significativo ao nível de $1 \%$ de probabilidade 
Tabela 5.4. Quadrados médios da análise de variância e suas respectivas significâncias pelo teste $F$, para os descritores 40 a 46.

\begin{tabular}{|c|c|c|c|c|c|c|c|c|c|}
\hline F.V. & GL & & 40 & 41 & 42 & 43 & 44 & 45 & 46 \\
\hline Etnovarariedades & 55 & $\mathrm{QM}_{11}$ & $1,713^{*}$ & $9,448^{* *}$ & $0,017^{*}$ & $0,915^{* *}$ & $2,356^{\circ}$ & $0,091^{* *}$ & $64.650 "$ \\
\hline Regiões (A) & 2 & $\mathrm{QM}_{10}$ & $0,165^{\mathrm{ns}}$ & $22,457^{\mathrm{ns}}$ & $0.001^{\mathrm{ns}}$ & $3.346^{\mathrm{ns}}$ & $7.597^{1 \mathrm{ss}}$ & $0.092^{\mathrm{ns}}$ & $300.601^{\mathrm{ns}}$ \\
\hline Roças/A & 14 & $\mathrm{QM}_{9}$ & $3,013^{*}$ & $16,314^{* *}$ & $0,026^{\text {ns }}$ & $1,228^{\mathrm{ns}}$ & $3,546^{*}$ & $0.093^{\mathrm{ns}}$ & $65,597^{\mathrm{ns}}$ \\
\hline Etnovar/R/A & 39 & $\mathrm{QM}_{8}$ & $1.326^{*}$ & $6,317^{*}$ & $0.015^{*}$ & $0,677^{*}$ & $1,661^{*}$ & $0,090^{* *}$ & $52.210^{\circ}$ \\
\hline Roças/Al & 6 & $\mathrm{QM}_{7}$ & $5,138^{* *}$ & $35,505^{* *}$ & $0,009^{n s}$ & $2,280^{\mathrm{ns}}$ & $6,319^{*}$ & $0,081^{\mathrm{ns}}$ & $123,527^{\text {ns }}$ \\
\hline Etnovar/R/Al & 23 & $\mathrm{QM}_{6}$ & $1,160^{*}$ & $7,964^{* *}$ & $0,015^{* *}$ & $0,922^{* *}$ & $1,793^{* *}$ & $0,073^{* *}$ & $50,773^{*}$ \\
\hline Roças/A2 & 3 & $\mathrm{QM}_{5}$ & $0,406^{\mathrm{ns}}$ & $1,696^{\mathrm{ns}}$ & $0,048^{\mathrm{ns}}$ & $0,331^{\mathrm{ns}}$ & $0,642^{\mathrm{ns}}$ & $0,080^{\mathrm{ns}}$ & $28,894^{\text {ns }}$ \\
\hline Etnovar/R/A2 & 12 & $\mathrm{QM}_{4}$ & $1,763^{*}$ & $5,073^{* *}$ & $0,016^{*}$ & $0.410^{* \bullet}$ & $1,678^{* *}$ & $0,142^{* *}$ & $66.519^{* \bullet}$ \\
\hline Roças/A3 & 5 & $\mathrm{QM}_{3}$ & $2,027^{\text {ns }}$ & $2,055^{\mathrm{ns}}$ & $0,033^{\text {ns }}$ & $0,504^{*}$ & $1,960^{\mathrm{ns}}$ & $0,117^{\mathrm{ns}}$ & $18,104^{\text {ns }}$ \\
\hline Etnovar/R/A3 & 4 & $\mathrm{QM}_{2}$ & $0,968^{*}$ & $0,579^{* *}$ & $0,013^{\circ}$ & $0,077^{* *}$ & $0.851^{* *}$ & $0,030^{\mathrm{ns}}$ & $17,547^{\mathrm{ns}}$ \\
\hline Resíduo & 110 & $\mathrm{QM}_{1}$ & 0,009 & 0,054 & 0,004 & 0,011 & 0,012 & 0,013 & 12,139 \\
\hline $\mathrm{CV}_{\mathrm{e}}(\%)$ & & & 3,52 & 0,26 & 7,39 & 4,46 & 2,69 & 6,65 & 5.57 \\
\hline
\end{tabular}

A: Regiões, efeito aleatório

A1: Rio Negro - Bacia Amazônica

A2: Rio Solimões - Bacia Amazônica

A3: Litoral sul - SP

R: Roça, efeito aleatório

$\mathrm{V}$ : etnovariedades, efeito aleatório

ns. Teste $\mathrm{F}$, não significativo ao $5 \%$ de probabilidade

* Teste $\mathrm{F}$, significativo ao nivel de $5 \%$ de probabilidade

** Teste F, significativo ao nivel de $1 \%$ de probabilidade 
Tabela 6. Estimativas da variância genética $\left(\hat{\sigma}_{G}^{2}\right)$, da variância ambiental $\left(\hat{\sigma}_{E}^{2}\right)$, do coeficiente de herdabilidade ao nivel de médias $\left(\hat{h}_{m}^{2}\right)$, do coeficiente de herdabilidade ao nivel de parcelas $\left(\hat{h}_{p}^{2}\right)$, do coeficiente de variação genética $\left(\mathrm{CV}_{\mathrm{g}}\right)$ e da razão $\mathrm{CV}_{\mathrm{g}} / \mathrm{CV}_{\mathrm{e}}$, para as variáveis 15 a 46 .

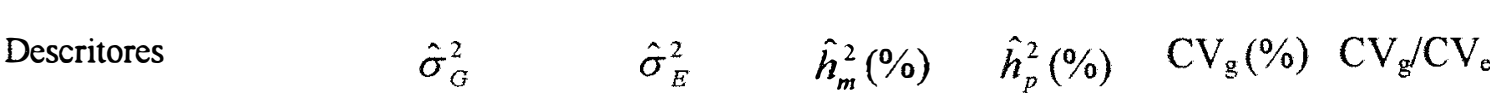

\begin{tabular}{|c|c|c|c|c|c|c|}
\hline 15 (PR) & 1,3511 & 0,5100 & 88.82 & 72.60 & 56.09 & 1.62 \\
\hline $16(\mathrm{PA})$ & 1,3014 & 0.9423 & 80.55 & 58.00 & +1.66 & 1.17 \\
\hline 17 (IC) & 0,0075 & 0,0038 & 85.58 & 66.46 & 20,78 & 1.41 \\
\hline 18 (NR) & 0,1770 & 0,0658 & 88,97 & 72.90 & 15.34 & 1.63 \\
\hline $19(\mathrm{AS})$ & 0,2194 & 0,0705 & 90,32 & 75,68 & 64.14 & 1.76 \\
\hline 20 (CNTF) & 57483,4297 & 187525,9687 & 47,90 & 23,46 & 21.69 & 0.55 \\
\hline 21 (CNLF) & 2827,9788 & 6401,7514 & 56,99 & 30,64 & 27,59 & 0,66 \\
\hline $22(\mathrm{MSF})\left(^{*}\right)$ & 3,4051 & 23,6584 & 30,15 & 12,58 & 5.45 & 0,37 \\
\hline $23(\mathrm{PrF})$ & 1,6933 & 4,2781 & 54,28 & 28,36 & 5.33 & 0,62 \\
\hline 24 (MGF) & 0,9595 & 1,0923 & 72,49 & 46,76 & 14,62 & 0,93 \\
\hline $25(\mathrm{CzF})$ & 1,0094 & 0,8891 & 77,30 & 53,17 & 13,54 & 1,06 \\
\hline $26(\mathrm{FF})$ & 2,1071 & 0,8898 & 87,66 & 70,31 & 8,12 & 1,53 \\
\hline 28 (UC) & 8,6523 & 19,4537 & 57,16 & 30,78 & 4.59 & 0,66 \\
\hline $29(\mathrm{CzC})$ & 1,4178 & 0,0942 & 97,83 & 93,77 & 23.36 & 3,88 \\
\hline $30(\mathrm{PrC})$ & 2,0857 & 0,0755 & 98,80 & 96,51 & 28.49 & 5,25 \\
\hline $31(\mathrm{FC})$ & 12,5163 & 0,4328 & 98,86 & 96,66 & 6.63 & 5,37 \\
\hline 32 (MGC) & 0,0883 & 0,0324 & 89,11 & 73,18 & 19.83 & 1.65 \\
\hline $33(\mathrm{CbC})$ & 3,9005 & 5,6963 & 67,25 & 40.64 & 6.11 & 0.82 \\
\hline 34 (CNTER) & 6185,8213 & 267,1947 & 98,58 & 95,86 & 62.04 & 4,81 \\
\hline 35 (CNLER) & 56,6610 & 2,5030 & 98,54 & 95.77 & 62.93 & 4.75 \\
\hline 36 (CNTPR) & 258,6989 & 40,4650 & 95,04 & 86,47 & 52.27 & 2.52 \\
\hline 37 (CNLPR) & 2,4866 & 0,6593 & 91,87 & 79,04 & 52.59 & 1,94 \\
\hline 38 (UER) & 7,7870 & 17,0925 & 57,74 & 31,30 & 4.54 & 0,67 \\
\hline 39 (UPR) & 21,4870 & 12,7305 & 83,50 & 62,80 & 7.51 & 1,29 \\
\hline 40 (PrR) & 0,5682 & 0,0086 & 99,50 & 98,51 & 28,62 & 8,12 \\
\hline $41(\mathrm{AR})$ & 3,1323 & 0,0525 & 99,44 & 98,35 & 2.01 & 7,72 \\
\hline 42 (MGR) & 0,0044 & 0,0039 & 77,30 & 53,18 & 7,87 & 1,06 \\
\hline 43 (CzR) & 0,3012 & 0,0112 & 98,77 & 96,41 & 23.14 & 5,18 \\
\hline 44 (FR) & 0,7815 & 0,0121 & 99,49 & 98,48 & 21.61 & 8,05 \\
\hline 45 (AçR) & 0,0261 & 0,0128 & 85,95 & 67,11 & 9.50 & 1,42 \\
\hline 46 (UR) & 17,5081 & 12,1341 & 81,23 & 59,06 & 6.69 & 1.20 \\
\hline
\end{tabular}

(*) A variável 22, Teor de umidade nas folhas, não apresentou significância pelo teste $F_{50 \%}$ 
Tabela 7 . Teste de Tukey a $5 \%$ de probabilidade, variável 15 Peso de Raízes $(\mathrm{kg} / \mathrm{planta}), \Delta_{5 \%}=2,4308$.

\begin{tabular}{|c|c|c|c|c|c|c|c|c|c|c|c|c|}
\hline Etnov. & Região & Média & $A$ & $\bar{B}$ & $\mathrm{C}$ & $\bar{D}$ & $\mathrm{E}$ & $\mathrm{F}$ & $\mathrm{G}$ & $\mathrm{H}$ & 1 & $\mathrm{~J}$ \\
\hline DG127 & 3 & 5,493 & A & & & & & & & & & \\
\hline DG132 & 3 & 4.877 & A & B & & & & & & & & \\
\hline DG126 & 3 & 4.223 & A & B & C & & & & & & & \\
\hline DG130 & 3 & 3.957 & A & B & C & D & & & & & & \\
\hline MANT & IAC & 3.910 & A & B & C & D & & & & & & \\
\hline DG133 & 3 & 3,870 & A & B & C & D & E & & & & & \\
\hline DG65 & 1 & 3,790 & A & B & C & D & $\mathrm{E}$ & $\mathrm{F}$ & & & & \\
\hline DG134 & 3 & 3.770 & A & B & C & D & $\mathrm{E}$ & $\mathrm{F}$ & & & & \\
\hline DG128 & 3 & 3,623 & A & B & $\mathrm{C}$ & D & E & $\mathrm{F}$ & G & & & \\
\hline DG73 & 1 & 3.320 & A & B & C & D & E & $\mathrm{F}$ & G & $\mathrm{H}$ & & \\
\hline DG117 & 2 & 3.310 & A & B & C & D & E & $\mathrm{F}$ & G & $\mathrm{H}$ & & \\
\hline DG67 & 1 & 3.220 & A & B & $\mathrm{C}$ & D & $\mathrm{E}$ & $\mathrm{F}$ & G & $\mathrm{H}$ & & \\
\hline DG38 & 1 & 3.213 & A & B & C & D & $\mathrm{E}$ & $\mathrm{F}$ & G & $\mathrm{H}$ & & \\
\hline DG115 & 2 & 2.983 & & B & C & D & E & $\mathrm{F}$ & G & $\mathrm{H}$ & I & \\
\hline DG129 & 3 & 2.810 & & B & C & D & E & $\mathrm{F}$ & G & $\mathrm{H}$ & I & $\mathrm{J}$ \\
\hline DG111 & 2 & 2.803 & & B & C & D & E & $\mathrm{F}$ & G & $\mathrm{H}$ & I & $\mathrm{J}$ \\
\hline DG124 & 2 & 2,717 & & B & $\mathrm{C}$ & D & E & $\mathrm{F}$ & G & $\mathrm{H}$ & I & $\mathrm{J}$ \\
\hline DG131 & 3 & 2,447 & & B & C & D & E & $\mathrm{F}$ & G & $\mathrm{H}$ & I & $\mathrm{J}$ \\
\hline DG123 & 2 & 2,427 & & & C & D & E & $\mathrm{F}$ & G & $\mathrm{H}$ & I & $\mathrm{J}$ \\
\hline DG118 & 2 & 2.420 & & & C & D & E & $\mathrm{F}$ & G & $\mathrm{H}$ & I & $\mathrm{J}$ \\
\hline DG68 & 1 & 2,337 & & & C & D & E & $\mathrm{F}$ & G & $\mathrm{H}$ & I & $\mathrm{J}$ \\
\hline DG125 & 2 & 2.247 & & & C & D & E & $\mathrm{F}$ & G & $\mathrm{H}$ & I & J \\
\hline DG119 & 2 & 2,220 & & & C & D & E & $\mathrm{F}$ & G & $\mathrm{H}$ & I & $\mathrm{J}$ \\
\hline DG48 & 1 & 2.200 & & & C & D & E & $\mathrm{F}$ & G & $\mathrm{H}$ & I & $\mathrm{J}$ \\
\hline DG55 & 1 & 2,113 & & & C & D & E & $\mathrm{F}$ & G & $\mathrm{H}$ & I & $\mathrm{J}$ \\
\hline DG116 & 2 & 2.087 & & & C & $\mathrm{D}$ & E & $\mathrm{F}$ & G & $\mathrm{H}$ & I & $\mathrm{J}$ \\
\hline DG113 & 2 & 1,987 & & & C & D & E & $\mathrm{F}$ & G & $\mathrm{H}$ & I & $\mathrm{J}$ \\
\hline DG47 & 1 & 1.980 & & & $\mathrm{C}$ & D & E & $\mathrm{F}$ & G & $\mathrm{H}$ & I & $\mathrm{J}$ \\
\hline DG45 & 1 & 1,937 & & & C & D & E & $\mathrm{F}$ & G & $\mathrm{H}$ & I & J \\
\hline DG120 & 2 & 1,603 & & & & D & E & $\mathrm{F}$ & G & $\mathrm{H}$ & I & J \\
\hline DG114 & 2 & 1.527 & & & & D & $\mathrm{E}$ & $\mathrm{F}$ & G & $\mathrm{H}$ & I & $\mathrm{J}$ \\
\hline DG44 & 1 & 1.460 & & & & & E & $\mathrm{F}$ & G & $\mathrm{H}$ & I & $\mathrm{J}$ \\
\hline DG61 & 1 & 1,433 & & & & & & $\mathrm{~F}$ & G & $\mathrm{H}$ & I & J \\
\hline DG43 & 1 & 1,420 & & & & & & $\mathrm{~F}$ & G & $\mathrm{H}$ & I & J \\
\hline DG49 & I & 1,400 & & & & & & $\mathrm{~F}$ & G & $\mathrm{H}$ & I & J \\
\hline DG56 & 1 & 1.370 & & & & & & $\mathrm{~F}$ & G & $\mathrm{H}$ & I & J \\
\hline DG51 & 1 & 1,310 & & & & & & & G & $\mathrm{H}$ & I & J \\
\hline DG46 & 1 & 1,263 & & & & & & & G & $\mathrm{H}$ & I & $\mathrm{J}$ \\
\hline DG70 & 1 & 1.230 & & & & & & & G & $\mathrm{H}$ & I & $\mathrm{J}$ \\
\hline DG112 & 2 & 1.097 & & & & & & & & $\mathrm{H}$ & I & $\mathrm{J}$ \\
\hline DG122 & 2 & 1,097 & & & & & & & & $\mathrm{H}$ & I & $\mathrm{J}$ \\
\hline DG58 & 1 & 1.003 & & & & & & & & $\mathrm{H}$ & I & $\mathrm{J}$ \\
\hline DG60 & 1 & 0,950 & & & & & & & & $\mathrm{H}$ & I & $\mathrm{J}$ \\
\hline DG138 & 2 & 0.943 & & & & & & & & $\mathrm{H}$ & I & $\mathrm{J}$ \\
\hline DG69 & 1 & 0,930 & & & & & & & & $\mathrm{H}$ & I & $\mathrm{J}$ \\
\hline DG52 & 1 & 0.910 & & & & & & & & $\mathrm{H}$ & I & J \\
\hline DG62 & 1 & 0,907 & & & & & & & & $\mathrm{H}$ & I & J \\
\hline DG39 & $i$ & 0.890 & & & & & & & & $\mathrm{H}$ & I & $\mathrm{J}$ \\
\hline DG40 & 1 & 0,727 & & & & & & & & & I & $\mathrm{J}$ \\
\hline DG71 & 1 & 0.717 & & & & & & & & & I & J \\
\hline DG41 & 1 & 0,703 & & & & & & & & & I & $\mathrm{J}$ \\
\hline DG50 & 1 & 0,700 & & & & & & & & & I & $\mathrm{J}$ \\
\hline DG121 & 2 & 0,690 & & & & & & & & & I & $\mathrm{J}$ \\
\hline DG59 & 1 & 0.623 & & & & & & & & & I & $\mathrm{J}$ \\
\hline DG42 & 1 & 0.437 & & & & & & & & & & $\mathrm{~J}$ \\
\hline DG54 & 1 & 0.407 & & & & & & & & & & $\mathrm{~J}$ \\
\hline
\end{tabular}

Região 1: Rio Negro - Bacia Amazônica

Região 2: Rio Solimões - Bacia Amazònica

Região 3: Litoral Sul - SP 
Tabela 8 . Teste de Tukey a $5 \%$ de probabilidade, variável 16 Peso de Peso da parte aérea (kg/planta), $\Delta_{\varsigma \%}=3,3038$.

\begin{tabular}{|c|c|c|c|c|c|c|c|c|c|}
\hline Etnov. & Região & Média & $\mathrm{A}$ & B & $\mathrm{C}$ & $\mathrm{D}$ & $E$ & $\mathrm{~F}$ & $\mathrm{G}$ \\
\hline DG134 & 3 & 6,843 & A & & & & & & \\
\hline DG132 & 3 & 5,793 & A & B & & & & & \\
\hline DG117 & 2 & 5.343 & A & B & C & & & & \\
\hline DG127 & 3 & 4,780 & A & B & C & D & & & \\
\hline DG130 & 3 & 4,777 & A & B & C & D & & & \\
\hline DG56 & 1 & 4,387 & A & B & C & D & E & & \\
\hline DG47 & 1 & 4,197 & A & B & C & D & E & $\mathrm{F}$ & \\
\hline DG118 & 2 & 4.153 & A & B & C & D & E & $\mathrm{F}$ & G \\
\hline MANT & $\mathrm{IAC}$ & 4.010 & A & B & $\mathrm{C}$ & D & E & $\mathrm{F}$ & G \\
\hline DG111 & 2 & 3.710 & A & B & C & D & $E$ & $\mathrm{~F}$ & G \\
\hline DG73 & 1 & 3.620 & A & B & C & D & E & $\mathrm{F}$ & G \\
\hline DG119 & 2 & 3.477 & & B & $\mathrm{C}$ & D & $\mathrm{E}$ & $\mathrm{F}$ & G \\
\hline DG43 & 1 & 3.450 & & B & $\mathrm{C}$ & D & E & $\mathrm{F}$ & G \\
\hline DG133 & 3 & 3,437 & & B & C & D & E & $\mathrm{F}$ & G \\
\hline DG116 & 2 & 3.303 & & B & $\mathrm{C}$ & D & $\mathrm{E}$ & $\mathrm{F}$ & G \\
\hline DG51 & 1 & 3.227 & & B & C & D & E & $\mathrm{F}$ & G \\
\hline DG67 & 1 & 3.140 & & B & C & D & E & $\mathrm{F}$ & G \\
\hline DG128 & 3 & 3,100 & & B & $\mathrm{C}$ & D & $\mathrm{E}$ & $\mathrm{F}$ & G \\
\hline DG65 & 1 & 3,077 & & B & C & D & E & $\mathrm{F}$ & G \\
\hline DG45 & 1 & 3,037 & & B & C & D & E & $\mathrm{F}$ & G \\
\hline DG124 & 2 & 2,907 & & B & $\mathrm{C}$ & D & E & $\mathrm{F}$ & G \\
\hline DG112 & 2 & 2,877 & & B & C & D & E & $\mathrm{F}$ & G \\
\hline DG48 & 1 & 2,870 & & B & C & D & E & $\mathrm{F}$ & G \\
\hline DG120 & 2 & 2,807 & & B & $\mathrm{C}$ & D & $\mathrm{E}$ & $\mathrm{F}$ & G \\
\hline DG55 & 1 & 2.787 & & B & C & D & E & $\mathrm{F}$ & G \\
\hline DG126 & 2 & 2,770 & & B & C & D & E & $\mathrm{F}$ & G \\
\hline DG38 & 1 & 2,750 & & B & $\mathrm{C}$ & D & $\mathrm{E}$ & $\mathrm{F}$ & G \\
\hline DG46 & 1 & 2.740 & & B & $\mathrm{C}$ & D & $\mathrm{E}$ & $\mathrm{F}$ & G \\
\hline DG68 & 1 & 2.620 & & B & C & D & E & $\mathrm{F}$ & G \\
\hline DG115 & 2 & 2,557 & & B & C & D & E & $\mathrm{F}$ & G \\
\hline DG125 & 2 & 2,550 & & B & $\mathrm{C}$ & D & $\mathrm{E}$ & $\mathrm{F}$ & G \\
\hline DG113 & 2 & 2.547 & & B & C & D & $\mathrm{E}$ & $\mathrm{F}$ & G \\
\hline DG44 & 1 & 2.533 & & B & $\mathrm{C}$ & D & E & $\mathrm{F}$ & G \\
\hline DG114 & 2 & 2,507 & & B & $\mathrm{C}$ & D & $\mathrm{E}$ & $\mathrm{F}$ & G \\
\hline DG123 & 2 & 2.467 & & & C & D & $\mathrm{E}$ & $\mathrm{F}$ & G \\
\hline DG61 & 1 & 2,237 & & & $\mathrm{C}$ & D & E & $\mathrm{F}$ & G \\
\hline DG58 & 1 & 2,233 & & & $\mathrm{C}$ & D & $\mathrm{E}$ & $\mathrm{F}$ & G \\
\hline DG131 & 3 & 2.073 & & & C & D & $\mathrm{E}$ & $\mathrm{F}$ & G \\
\hline DG129 & 3 & 2,017 & & & & D & $\mathrm{E}$ & $\mathrm{F}$ & G \\
\hline DG52 & 1 & 1,907 & & & & D & $\mathrm{E}$ & $\mathrm{F}$ & G \\
\hline DG49 & 1 & 1,883 & & & & D & $\mathrm{E}$ & $\mathrm{F}$ & G \\
\hline DG62 & 1 & 1,870 & & & & D & E & $\mathrm{F}$ & G \\
\hline DG138 & 2 & 1.770 & & & & D & E & $\mathrm{F}$ & G \\
\hline DG50 & 1 & 1,660 & & & & D & $\mathrm{E}$ & $\mathrm{F}$ & G \\
\hline DG39 & 1 & 1.600 & & & & D & E & $\mathrm{F}$ & G \\
\hline DG71 & 1 & 1,580 & & & & D & E & $\mathrm{F}$ & G \\
\hline DG70 & 1 & 1.427 & & & & & $\mathrm{E}$ & $\mathrm{F}$ & G \\
\hline DG60 & 1 & 1,407 & & & & & $\mathrm{E}$ & $\mathrm{F}$ & G \\
\hline DG121 & 2 & 1.333 & & & & & E & $\mathrm{F}$ & G \\
\hline DG54 & 1 & 1,230 & & & & & $\mathrm{E}$ & $\mathrm{F}$ & G \\
\hline DG59 & 1 & 1,070 & & & & & & $\mathrm{~F}$ & G \\
\hline DG42 & 1 & 1,063 & & & & & & $\mathrm{~F}$ & G \\
\hline DG40 & i & 1.043 & & & & & & $\mathrm{~F}$ & G \\
\hline DG69 & 1 & 1,003 & & & & & & $\mathrm{~F}$ & G \\
\hline DG122 & 2 & 0,917 & & & & & & $\mathrm{~F}$ & G \\
\hline DG41 & 1 & 0,867 & & & & & & & $\mathrm{G}$ \\
\hline
\end{tabular}

Região 1: Rio Negro - Bacia Amazònica

Região 2: Rio Solimões - Bacia Amazònica

Região 3: Litoral Sul - SP 
Tabela 9. Teste de Tukey a 5\% de probabilidade, variável 17 Índice de Colheita. $\Delta_{5^{\circ}}=0.2086$.

\begin{tabular}{|c|c|c|c|c|c|c|c|c|c|c|c|c|c|}
\hline Etnov. & Região & Média & $\mathrm{A}$ & B & $\mathrm{C}$ & $\mathrm{D}$ & $E$ & $\mathrm{~F}$ & $\bar{G}$ & $\mathrm{H}$ & I & $\mathrm{J}$ & $\bar{K}$ \\
\hline DG126 & 3 & 0.6277 & A & & & & & & & & & & \\
\hline DG129 & 3 & 0,5873 & $A$ & B & & & & & & & & & \\
\hline DG65 & 1 & 0.5523 & $A$ & B & C & & & & & & & & \\
\hline DG128 & 3 & 0,5507 & $A$ & B & $\mathrm{C}$ & & & & & & & & \\
\hline DG122 & 2 & 0.5477 & A & B & $\mathrm{C}$ & & & & & & & & \\
\hline DG131 & 3 & 0.5400 & $A$ & B & $\mathrm{C}$ & & & & & & & & \\
\hline DG38 & 1 & 0.5393 & A & B & C & & & & & & & & \\
\hline DG115 & 2 & 0.5360 & $A$ & B & $\mathrm{C}$ & & & & & & & & \\
\hline DG127 & 3 & 0.5337 & A & B & $\mathrm{C}$ & D & & & & & & & \\
\hline DG133 & 3 & 0.5290 & A & B & $\mathrm{C}$ & D & $E$ & & & & & & \\
\hline DG67 & 1 & 0.5050 & $A$ & B & $\mathrm{C}$ & D & $E$ & $\mathrm{~F}$ & & & & & \\
\hline DG123 & 2 & 0,5020 & $A$ & B & $\mathrm{C}$ & $\mathrm{D}$ & $E$ & $\mathrm{~F}$ & & & & & \\
\hline MANT & IAC & 0.4980 & $A$ & B & $\mathrm{C}$ & $\mathrm{D}$ & $\mathrm{E}$ & $\mathrm{F}$ & G & & & & \\
\hline DG69 & 1 & 0.4843 & $A$ & B & $\mathrm{C}$ & $\mathrm{D}$ & E & $\mathrm{F}$ & G & $\mathrm{H}$ & & & \\
\hline DG124 & 2 & 0.4830 & $A$ & B & $\mathrm{C}$ & D & $E$ & $\mathrm{~F}$ & G & $\mathrm{H}$ & & & \\
\hline DG73 & 1 & 0.4763 & $A$ & B & $\mathrm{C}$ & $\mathrm{D}$ & $E$ & $\mathrm{~F}$ & G & $\mathrm{H}$ & & & \\
\hline DG70 & 1 & 0.4667 & A & B & C & D & $E$ & $\mathrm{~F}$ & G & $\mathrm{H}$ & 1 & & \\
\hline DG68 & 1 & 0,4650 & A & B & C & D & $\mathrm{E}$ & $\mathrm{F}$ & G & $\mathrm{H}$ & I & & \\
\hline DG125 & 2 & 0.4650 & $A$ & B & $\mathrm{C}$ & $\mathrm{D}$ & $E$ & $\mathrm{~F}$ & G & $\mathrm{H}$ & I & & \\
\hline DG130 & 3 & 0,4580 & A & B & $\mathrm{C}$ & D & $E$ & $\mathrm{~F}$ & G & $\mathrm{H}$ & 1 & & \\
\hline DG41 & 1 & 0,4537 & $A$ & B & $\mathrm{C}$ & D & $E$ & $\mathrm{~F}$ & G & $\mathrm{H}$ & I & & \\
\hline DG132 & 3 & 0.4510 & $A$ & B & $\mathrm{C}$ & $\mathrm{D}$ & $E$ & $\mathrm{~F}$ & G & $\mathrm{H}$ & I & & \\
\hline DG111 & 2 & 0,4410 & $A$ & B & $\mathrm{C}$ & $\mathrm{D}$ & $E$ & $\mathrm{~F}$ & G & $\mathrm{H}$ & I & $\mathrm{J}$ & \\
\hline DG48 & 1 & 0,4317 & $A$ & B & $\mathrm{C}$ & $\mathrm{D}$ & $E$ & $\mathrm{~F}$ & G & $\mathrm{H}$ & I & $\mathrm{J}$ & $\mathrm{K}$ \\
\hline DG55 & 1 & 0,4303 & $A$ & B & $\mathrm{C}$ & D & E & $\mathrm{F}$ & G & $\mathrm{H}$ & I & $\mathrm{J}$ & $\mathrm{K}$ \\
\hline DG113 & 2 & 0,4297 & $A$ & B & $\mathrm{C}$ & D & $E$ & $\mathrm{~F}$ & G & $\mathrm{H}$ & I & $\mathrm{J}$ & $\mathrm{k}$ \\
\hline DG49 & 1 & 0,4187 & & B & C & D & $E$ & $\mathrm{~F}$ & G & $\mathrm{H}$ & I & $\mathrm{J}$ & $\mathrm{k}$ \\
\hline DG40 & 1 & 0,4137 & & B & $\mathrm{C}$ & D & $E$ & $\mathrm{~F}$ & G & $\mathrm{H}$ & I & $\mathrm{J}$ & $\mathrm{k}$ \\
\hline DG60 & 1 & 0.4070 & & B & $\mathrm{C}$ & D & $E$ & $\mathrm{~F}$ & G & $\mathrm{H}$ & I & $\mathrm{J}$ & $\mathrm{k}$ \\
\hline DG45 & 1 & 0.3887 & & B & $\mathrm{C}$ & D & $E$ & $\mathrm{~F}$ & G & $\mathrm{H}$ & I & $\mathrm{J}$ & $\mathrm{k}$ \\
\hline DG116 & 2 & 0.3863 & & B & $\mathrm{C}$ & D & $E$ & $\mathrm{~F}$ & G & $\mathrm{H}$ & I & $\mathrm{J}$ & $\mathrm{K}$ \\
\hline DG117 & 2 & 0,3827 & & B & $\mathrm{C}$ & D & E & $\mathrm{F}$ & G & $\mathrm{H}$ & I & $\mathrm{J}$ & $\mathrm{K}$ \\
\hline DG114 & 2 & 0.3800 & & B & $\mathrm{C}$ & D & $E$ & $\mathrm{~F}$ & G & $\mathrm{H}$ & I & $\mathrm{J}$ & $\mathrm{k}$ \\
\hline DG119 & 2 & 0.3777 & & & $\mathrm{C}$ & $\mathrm{D}$ & $E$ & $\mathrm{~F}$ & G & $\mathrm{H}$ & I & $\mathrm{J}$ & $\mathrm{K}$ \\
\hline DG61 & 1 & 0.3727 & & & $\mathrm{C}$ & D & $E$ & $\mathrm{~F}$ & G & $\mathrm{H}$ & I & $\mathrm{J}$ & $\mathrm{k}$ \\
\hline DG120 & 2 & 0,3710 & & & $\mathrm{C}$ & $\mathrm{D}$ & $E$ & $\mathrm{~F}$ & G & $\mathrm{H}$ & I & $\mathrm{J}$ & $\mathrm{K}$ \\
\hline DG59 & 1 & 0.3700 & & & $\mathrm{C}$ & D & $E$ & $\mathrm{~F}$ & G & $\mathrm{H}$ & I & $\mathrm{J}$ & $\mathrm{k}$ \\
\hline DG118 & 2 & 0,3680 & & & $\mathrm{C}$ & D & E & $\mathrm{F}$ & G & $\mathrm{H}$ & I & $\mathrm{J}$ & $\mathrm{k}$ \\
\hline DG44 & 1 & 0,3650 & & & C & D & $E$ & $\mathrm{~F}$ & G & $\mathrm{H}$ & I & $\mathrm{J}$ & $\mathrm{k}$ \\
\hline DG134 & 3 & 0,3547 & & & $\mathrm{C}$ & D & $E$ & $\mathrm{~F}$ & G & $\mathrm{H}$ & I & $\mathrm{J}$ & $\mathrm{K}$ \\
\hline DG39 & 1 & 0,3533 & & & $\mathrm{C}$ & $\mathrm{D}$ & $E$ & $\mathrm{~F}$ & G & $\mathrm{H}$ & I & $\mathrm{J}$ & $\mathrm{K}$ \\
\hline DG46 & 1 & 0,3530 & & & $\mathrm{C}$ & D & E & $\mathrm{F}$ & G & $\mathrm{H}$ & I & $\mathrm{J}$ & $\mathrm{K}$ \\
\hline DG121 & 2 & 0.3473 & & & $\mathrm{C}$ & D & $E$ & $\mathrm{~F}$ & G & $\mathrm{H}$ & 1 & $\mathrm{~J}$ & $\mathrm{k}$ \\
\hline DG138 & 2 & 0,3463 & & & $\mathrm{C}$ & D & $E$ & $\mathrm{~F}$ & G & $\mathrm{H}$ & I & $\mathrm{J}$ & $\mathrm{k}$ \\
\hline DG47 & 1 & 0,3267 & & & & $\mathrm{D}$ & $E$ & $\mathrm{~F}$ & G & $\mathrm{H}$ & I & $\mathrm{J}$ & $\mathrm{K}$ \\
\hline DG52 & 1 & 0.3263 & & & & D & $\mathrm{E}$ & $\mathrm{F}$ & G & $\mathrm{H}$ & I & $\mathrm{J}$ & $\mathrm{k}$ \\
\hline DG71 & 1 & 0.3247 & & & & & $E$ & $\mathrm{~F}$ & G & $\mathrm{H}$ & I & $\mathrm{J}$ & $\mathrm{k}$ \\
\hline DG62 & 1 & 0,3220 & & & & & $E$ & $\mathrm{~F}$ & G & $\mathrm{H}$ & $I$ & $\mathrm{~J}$ & $\mathrm{~K}$ \\
\hline DG58 & 1 & 0.3120 & & & & & & $\mathrm{~F}$ & G & $\mathrm{H}$ & 1 & $\mathrm{~J}$ & $\mathrm{~K}$ \\
\hline DG43 & 1 & 0.3090 & & & & & & $\mathrm{~F}$ & G & $\mathrm{H}$ & I & $\mathrm{J}$ & $\mathrm{k}$ \\
\hline DGSI & 1 & 0.2913 & & & & & & & G & $\mathrm{H}$ & I & $\mathrm{J}$ & $\mathrm{K}$ \\
\hline DG42 & 1 & 0,2860 & & & & & & & & $\mathrm{H}$ & I & $\mathrm{J}$ & $\mathrm{K}$ \\
\hline DG112 & 2 & 0.2797 & & & & & & & & $\mathrm{H}$ & I & $\mathrm{J}$ & $\mathrm{K}$ \\
\hline DGS0 & 1 & 0.2673 & & & & & & & & & I & $\mathrm{J}$ & $\mathrm{K}$ \\
\hline DG56 & 1 & 0.2417 & & & & & & & & & & $\mathrm{~J}$ & $\mathrm{k}$ \\
\hline DG54 & 1 & 0.2290 & & & & & & & & & & & $\mathrm{~K}$ \\
\hline
\end{tabular}


Tabela 10. Teste de Tukey a 5\% de probabilidade. variável 18 número total de raízes por planta transformada $(\sqrt{\mathrm{x}+1}), \Delta_{5 \%}=0,8730$.

\begin{tabular}{|c|c|c|c|c|c|c|c|c|c|c|c|c|c|c|c|c|c|}
\hline Etnov. & Reg & $\begin{array}{c}\text { Med } \\
\text { transf }\end{array}$ & $\begin{array}{l}\text { Med } \\
\text { real }\end{array}$ & $A$ & B & $\mathrm{C}$ & $\mathrm{D}$ & 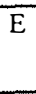 & $\bar{F}$ & $G$ & $\overline{\mathrm{H}}$ & I & $\mathrm{J}$ & $\mathrm{K}$ & $\bar{L}$ & $M$ & $\mathrm{~N}$ \\
\hline DG127 & 3 & 3,633 & 12,20 & A & & & & & & & & & & & & & \\
\hline DG117 & 2 & 3,530 & 11,46 & A & B & & & & & & & & & & & & \\
\hline DG38 & 1 & 3,527 & 11,44 & A & B & & & & & & & & & & & & \\
\hline DG128 & 3 & 3,357 & 10,27 & A & B & $\mathrm{C}$ & & & & & & & & & & & \\
\hline DG118 & 2 & 3.357 & 10,27 & A & B & $\mathrm{C}$ & & & & & & & & & & & \\
\hline DG47 & 1 & 3,337 & 10,14 & $A$ & B & $\mathrm{C}$ & $\mathrm{D}$ & & & & & & & & & & \\
\hline DG132 & 3 & 3,267 & 9,67 & A & B & $\mathrm{C}$ & $\mathrm{D}$ & $E$ & & & & & & & & & \\
\hline DG134 & 3 & 3.217 & 9,35 & A & B & $\mathrm{C}$ & $\mathrm{D}$ & $E$ & $\mathrm{~F}$ & & & & & & & & \\
\hline DG130 & 3 & 3.217 & 9,35 & A & B & $\mathrm{C}$ & $\mathrm{D}$ & $\mathrm{E}$ & $\mathrm{F}$ & & & & & & & & \\
\hline DG68 & 1 & 3,173 & 9,07 & A & B & $\mathrm{C}$ & D & $E$ & $\mathrm{~F}$ & & & & & & & & \\
\hline MANT & $\mathrm{IAC}$ & 3,177 & 9.09 & $A$ & B & $\mathrm{C}$ & $\mathrm{D}$ & $E$ & $\mathrm{~F}$ & & & & & & & & \\
\hline DG73 & 1 & 3.140 & 8,86 & A & B & $\mathrm{C}$ & D & $\mathrm{E}$ & $\mathrm{F}$ & G & & & & & & & \\
\hline DG124 & 2 & 3,120 & 8,73 & $A$ & B & $\mathrm{C}$ & D & $\mathrm{E}$ & $\mathrm{F}$ & G & & & & & & & \\
\hline DG125 & 2 & 3.113 & 8.69 & A & B & $\mathrm{C}$ & $\mathrm{D}$ & $E$ & $\mathrm{~F}$ & G & $\mathrm{H}$ & & & & & & \\
\hline DG65 & 1 & 3,083 & 8.50 & A & B & $\mathrm{C}$ & $\mathrm{D}$ & $\mathrm{E}$ & $\mathrm{F}$ & G & $\mathrm{H}$ & 1 & & & & & \\
\hline DG115 & 2 & 3.080 & 8.49 & $\mathrm{~A}$ & $\mathrm{~B}$ & $\mathrm{C}$ & $\mathrm{D}$ & $\mathrm{E}$ & $\mathrm{F}$ & G & $\mathrm{H}$ & $i$ & & & & & \\
\hline DG111 & 2 & 3,050 & 8,30 & A & B & $\mathrm{C}$ & $\mathrm{D}$ & $\mathrm{E}$ & $\mathrm{F}$ & G & $\mathrm{H}$ & 1 & $\mathrm{~J}$ & & & & \\
\hline DG126 & 3 & 3,046 & 8,28 & A & B & $\mathrm{C}$ & $\mathrm{D}$ & $\mathrm{E}$ & $\mathrm{F}$ & G & $\mathrm{H}$ & I & $\mathrm{J}$ & & & & \\
\hline DG131 & 3 & 2,993 & 7,96 & A & B & $\mathrm{C}$ & $\mathrm{D}$ & $\mathrm{E}$ & $\mathrm{F}$ & G & $\mathrm{H}$ & 1 & $\mathrm{~J}$ & $\mathrm{~K}$ & & & \\
\hline DG67 & 1 & 2,980 & 7,88 & $A$ & B & $\mathrm{C}$ & $\mathrm{D}$ & $\mathrm{E}$ & $\mathrm{F}$ & G & $\mathrm{H}$ & 1 & $\mathrm{~J}$ & $\mathrm{~K}$ & & & \\
\hline DG123 & 2 & 2,963 & 7,78 & $\mathrm{~A}$ & $\mathrm{~B}$ & $\mathrm{C}$ & $\mathrm{D}$ & E & $\mathrm{F}$ & G & $\mathrm{H}$ & I & $\mathrm{J}$ & $\mathrm{K}$ & & & \\
\hline DG129 & 3 & 2,923 & 7,54 & A & B & $\mathrm{C}$ & D & $\mathrm{E}$ & $\mathrm{F}$ & G & $\mathrm{H}$ & 1 & $\mathrm{~J}$ & $\mathrm{~K}$ & & & \\
\hline DG119 & 2 & 2,887 & 7,33 & A & $\mathrm{B}$ & $\mathrm{C}$ & $\mathrm{D}$ & $\mathrm{E}$ & $\mathrm{F}$ & G & $\mathrm{H}$ & I & $\mathrm{J}$ & $\mathrm{K}$ & $\mathrm{L}$ & & \\
\hline DG133 & 3 & 2.850 & 7,12 & A & B & $\mathrm{C}$ & D & $\mathrm{E}$ & $\mathrm{F}$ & G & $\mathrm{H}$ & I & $\mathrm{J}$ & $\mathrm{K}$ & $\mathrm{L}$ & M & \\
\hline DG116 & 2 & 2,830 & 7,01 & $A$ & B & $\mathrm{C}$ & $\mathrm{D}$ & $\mathrm{E}$ & $\mathrm{F}$ & G & $\mathrm{H}$ & $i$ & $\mathrm{~J}$ & $\mathrm{~K}$ & $\mathrm{~L}$ & $M$ & \\
\hline DG120 & 2 & 2,823 & 6,97 & A & B & $\mathrm{C}$ & D & E & $\mathrm{F}$ & G & $\mathrm{H}$ & I & $\mathrm{J}$ & $\mathrm{K}$ & $\mathrm{L}$ & $M$ & \\
\hline DG114 & 2 & 2,753 & 6,58 & & B & $\mathrm{C}$ & D & $E$ & $\mathrm{~F}$ & G & $\mathrm{H}$ & I & $\mathrm{J}$ & $\mathrm{K}$ & $\mathrm{L}$ & $M$ & $\mathrm{~N}$ \\
\hline DG45 & 1 & 2.747 & 6,55 & & B & $\mathrm{C}$ & $\mathrm{D}$ & $\mathrm{E}$ & $\mathrm{F}$ & G & $\mathrm{H}$ & I & $\mathrm{J}$ & $\mathrm{K}$ & L & $M$ & $\mathrm{~N}$ \\
\hline DG61 & 1 & 2,740 & 6,51 & & B & $\mathrm{C}$ & $\mathrm{D}$ & $\mathrm{E}$ & $\mathrm{F}$ & G & $\mathrm{H}$ & 1 & $\mathrm{~J}$ & $\mathrm{~K}$ & $\mathrm{~L}$ & $M$ & $\mathrm{~N}$ \\
\hline DG56 & 1 & 2,713 & 6,36 & & B & $\mathrm{C}$ & D & $E$ & $\mathrm{~F}$ & $\mathrm{G}$ & $\mathrm{H}$ & I & $\mathrm{J}$ & $\mathrm{K}$ & $\mathrm{L}$ & $M$ & $\mathrm{~N}$ \\
\hline DG138 & 2 & 2,647 & 6.01 & & & $\mathrm{C}$ & $\mathrm{D}$ & $\mathrm{E}$ & $\mathrm{F}$ & G & $\mathrm{H}$ & I & $\mathrm{J}$ & $\mathrm{K}$ & $\mathrm{L}$ & $M$ & $\mathrm{~N}$ \\
\hline DG58 & 1 & 2.630 & 5,92 & & & $\mathrm{C}$ & D & $\mathrm{E}$ & $\mathrm{F}$ & G & $\mathrm{H}$ & I & $\mathrm{J}$ & $\mathrm{K}$ & $\mathrm{L}$ & $M$ & $\mathrm{~N}$ \\
\hline DG44 & 1 & 2,627 & 5,90 & & & $\mathrm{C}$ & $\mathrm{D}$ & $\mathrm{E}$ & $\mathrm{F}$ & G & $\mathrm{H}$ & I & $\mathrm{J}$ & $\mathrm{K}$ & $\mathrm{L}$ & $M$ & $\mathrm{~N}$ \\
\hline DG113 & 2 & 2.590 & 5,71 & & & $\mathrm{C}$ & D & $\mathrm{E}$ & $\mathrm{F}$ & G & $\mathrm{H}$ & I & $\mathrm{J}$ & $\mathrm{K}$ & $\mathrm{L}$ & $M$ & $\mathrm{~N}$ \\
\hline DG55 & 1 & 2,587 & 5,69 & & & $\mathrm{C}$ & D & E & $\mathrm{F}$ & G & $\mathrm{H}$ & I & $\mathrm{J}$ & $\mathrm{K}$ & $\mathrm{L}$ & $M$ & $\mathrm{~N}$ \\
\hline DG112 & 2 & 2.580 & 5,66 & & & $\mathrm{C}$ & D & $\mathrm{E}$ & $\mathrm{F}$ & G & $\mathrm{H}$ & I & $\mathrm{J}$ & $\mathrm{K}$ & $\mathrm{L}$ & $M$ & $\mathrm{~N}$ \\
\hline DG49 & 1 & 2,580 & 5,66 & & & $\mathrm{C}$ & $\mathrm{D}$ & $\mathrm{E}$ & $\mathrm{F}$ & G & $\mathrm{H}$ & I & $\mathrm{J}$ & $\mathrm{K}$ & $\mathrm{L}$ & $M$ & $\mathrm{~N}$ \\
\hline DG39 & 1 & 2.550 & 5,50 & & & $\mathrm{C}$ & $\mathrm{D}$ & $E$ & $\mathrm{~F}$ & G & $\mathrm{H}$ & I & $\mathrm{J}$ & $\mathrm{K}$ & $\mathrm{L}$ & $M$ & $\mathrm{~N}$ \\
\hline DG51 & 1 & 2,517 & 5.34 & & & $\mathrm{C}$ & D & $\mathrm{E}$ & $\mathrm{F}$ & G & $\mathrm{H}$ & I & $\mathrm{J}$ & $\mathrm{K}$ & $\mathrm{L}$ & $M$ & $\mathrm{~N}$ \\
\hline DG48 & 1 & 2,467 & 5,09 & & & & D & $E$ & $\mathrm{~F}$ & G & $\mathrm{H}$ & I & $\mathrm{J}$ & $\mathrm{K}$ & $\mathrm{L}$ & $M$ & $\mathrm{~N}$ \\
\hline DG43 & 1 & 2,463 & 5,07 & & & & & $\mathrm{E}$ & $\mathrm{F}$ & G & $\mathrm{H}$ & I & $\mathrm{J}$ & $\mathrm{K}$ & $\mathrm{L}$ & $M$ & $\mathrm{~N}$ \\
\hline DG62 & 1 & 2,430 & 4,90 & & & & & E & $\mathrm{F}$ & G & $\mathrm{H}$ & I & $\mathrm{J}$ & $\mathrm{K}$ & $\mathrm{L}$ & $M$ & $\mathrm{~N}$ \\
\hline DG122 & 2 & 2,387 & 4,70 & & & & & & $\mathrm{~F}$ & G & $\mathrm{H}$ & $i$ & $\mathrm{~J}$ & $\mathrm{~K}$ & $\mathrm{~L}$ & $M$ & $\mathrm{~N}$ \\
\hline DG40 & 1 & 2.373 & 4,63 & & & & & & $\mathrm{~F}$ & G & $\mathrm{H}$ & I & $\mathrm{J}$ & $\mathrm{K}$ & $\mathrm{L}$ & $M$ & $\mathrm{~N}$ \\
\hline DG54 & $i$ & 2,343 & 4,49 & & & & & & & G & $\mathrm{H}$ & I & $\mathrm{J}$ & $\mathrm{K}$ & $\mathrm{L}$ & $M$ & $\mathrm{~N}$ \\
\hline DG41 & 1 & 2,300 & 4.29 & & & & & & & G & $\mathrm{H}$ & I & $\mathrm{J}$ & $\mathrm{K}$ & $\mathrm{L}$ & $M$ & $\mathrm{~N}$ \\
\hline DG70 & 1 & 2,243 & 4.03 & & & & & & & & $\mathrm{H}$ & I & $\mathrm{J}$ & $\mathrm{K}$ & L & $M$ & $\mathrm{~N}$ \\
\hline DG69 & 1 & 2.233 & 3,99 & & & & & & & & & I & J & $\mathrm{K}$ & $\mathrm{L}$ & $M$ & $\mathrm{~N}$ \\
\hline DG46 & $i$ & 2,200 & 3,84 & & & & & & & & & & $\mathrm{~J}$ & $\mathrm{~K}$ & $\mathrm{~L}$ & $M$ & $\mathrm{~N}$ \\
\hline DG59 & 1 & 2,187 & 3,78 & & & & & & & & & & $\mathrm{~J}$ & $\mathrm{~K}$ & $\mathrm{~L}$ & $M$ & $\mathrm{~N}$ \\
\hline DG60 & $i$ & 2,133 & 3.55 & & & & & & & & & & & $\mathrm{~K}$ & $\mathrm{~L}$ & $M$ & $\mathrm{~N}$ \\
\hline DG50 & 1 & 2.030 & 3.12 & & & & & & & & & & & & $\mathrm{~L}$ & $M$ & $\mathrm{~N}$ \\
\hline DG71 & $i$ & 2,000 & 3,00 & & & & & & & & & & & & & $M$ & $\mathrm{~N}$ \\
\hline DG52 & 1 & 1.997 & 2,99 & & & & & & & & & & & & & $M$ & $\mathrm{~N}$ \\
\hline DG42 & $i$ & 1,910 & 2.65 & & & & & & & & & & & & & & $\mathrm{~N}$ \\
\hline DG121 & 2 & 1.893 & 2.58 & & & & & & & & & & & & & & $\mathrm{~N}$ \\
\hline
\end{tabular}


Tabela 11 . Teste de Tukey a $5 \%$ de probabilidade, variável 19 produção de amido $\mathrm{Kg} /$ planta $\Delta_{\varsigma \%}=0,9037$.

\begin{tabular}{|c|c|c|c|c|c|c|c|c|c|c|c|c|c|c|}
\hline Etnov. & Região & Média & $\mathrm{A}$ & B & $\mathrm{C}$ & $\mathrm{D}$ & $E$ & $\mathrm{~F}$ & $\bar{G}$ & $\mathrm{H}$ & I & $\mathrm{J}$ & $\mathrm{K}$ & $\mathrm{L}$ \\
\hline DG127 & 3 & 2,050 & $A$ & & & & & & & & & & & \\
\hline DG132 & 3 & 2,010 & A & & & & & & & & & & & \\
\hline DG126 & 3 & 1,620 & A & B & & & & & & & & & & \\
\hline DG130 & 3 & 1.600 & A & B & C & & & & & & & & & \\
\hline DG134 & 3 & 1,457 & A & B & $\mathrm{C}$ & D & & & & & & & & \\
\hline DG128 & 3 & 1.423 & A & B & $\mathrm{C}$ & D & $\mathrm{E}$ & & & & & & & \\
\hline DG65 & 1 & 1,420 & A & $\mathrm{B}$ & $\mathrm{C}$ & $\mathrm{D}$ & $\mathrm{E}$ & & & & & & & \\
\hline DG133 & 3 & 1.340 & A & B & $\mathrm{C}$ & $\mathrm{D}$ & $\mathrm{E}$ & $\mathrm{F}$ & & & & & & \\
\hline MANT & IAC & 1,323 & A & B & C & D & E & $\mathrm{F}$ & G & & & & & \\
\hline DG38 & 1 & 1,253 & A & B & $\mathrm{C}$ & $\mathrm{D}$ & $\mathrm{E}$ & $\mathrm{F}$ & G & $\mathrm{H}$ & & & & \\
\hline DG67 & 1 & 1,200 & A & B & $\mathrm{C}$ & $\mathrm{D}$ & $\mathrm{E}$ & $\mathrm{F}$ & G & $\mathrm{H}$ & I & & & \\
\hline DG117 & 2 & 1.197 & A & B & C & $\mathrm{D}$ & $\mathrm{E}$ & $\mathrm{F}$ & G & $\mathrm{H}$ & I & & & \\
\hline DG124 & 2 & 1,177 & $A$ & B & $\mathrm{C}$ & $\mathrm{D}$ & $\mathrm{E}$ & $\mathrm{F}$ & G & $\mathrm{H}$ & I & $\mathrm{J}$ & & \\
\hline DG111 & 2 & 1.010 & & B & $\mathrm{C}$ & D & $\mathrm{E}$ & $\mathrm{F}$ & G & $\mathrm{H}$ & $I$ & $\mathrm{~J}$ & K & \\
\hline DG118 & 2 & 0.993 & & B & $\mathrm{C}$ & $\mathrm{D}$ & $E$ & $\mathrm{~F}$ & G & $\mathrm{H}$ & I & $\mathrm{J}$ & $\mathrm{K}$ & L \\
\hline DG129 & 3 & 0.983 & & B & $\mathrm{C}$ & D & $\mathrm{E}$ & $\mathrm{F}$ & G & $\mathrm{H}$ & 1 & $\mathrm{~J}$ & $\mathrm{~K}$ & $\mathrm{~L}$ \\
\hline DG131 & 3 & 0,980 & & B & $\mathrm{C}$ & $\mathrm{D}$ & $\mathrm{E}$ & $\mathrm{F}$ & G & $\mathrm{H}$ & I & $\mathrm{J}$ & $\mathrm{K}$ & $\mathrm{L}$ \\
\hline DG73 & 1 & 0.970 & & B & $\mathrm{C}$ & D & $\mathrm{E}$ & $\mathrm{F}$ & G & $\mathrm{H}$ & I & $\mathrm{J}$ & $\mathrm{K}$ & $\mathrm{L}$ \\
\hline DG115 & 2 & 0,940 & & $\mathrm{~B}$ & $\mathrm{C}$ & D & E & $\mathrm{F}$ & G & $\mathrm{H}$ & I & $\mathrm{J}$ & $\mathrm{K}$ & $\mathrm{L}$ \\
\hline DG119 & 2 & 0,820 & & B & C & D & E & $\mathrm{F}$ & G & $\mathrm{H}$ & I & $\mathrm{J}$ & K & L \\
\hline DG68 & 1 & 0,817 & & B & $\mathrm{C}$ & D & $\mathrm{E}$ & $\mathrm{F}$ & G & $\mathrm{H}$ & I & $\mathrm{J}$ & $\mathrm{K}$ & $\mathrm{L}$ \\
\hline DG113 & 2 & 0.773 & & B & $\mathrm{C}$ & D & $\mathrm{E}$ & $\mathrm{F}$ & G & $\mathrm{H}$ & I & $\mathrm{J}$ & $\mathrm{K}$ & L \\
\hline DG125 & 2 & 0,763 & & B & C & D & $\mathrm{E}$ & $\mathrm{F}$ & G & $\mathrm{H}$ & I & $\mathrm{J}$ & $\mathrm{K}$ & $\mathrm{L}$ \\
\hline DG123 & 2 & 0.760 & & B & $\mathrm{C}$ & D & $\mathrm{E}$ & $\mathrm{F}$ & G & $\mathrm{H}$ & I & $\mathrm{J}$ & $\mathrm{K}$ & L \\
\hline DG116 & 2 & 0,710 & & & $\mathrm{C}$ & D & $\mathrm{E}$ & $\mathrm{F}$ & G & $\mathrm{H}$ & I & $\mathrm{J}$ & $\mathrm{K}$ & $\mathrm{L}$ \\
\hline DG48 & 1 & 0.680 & & & & D & $\mathrm{E}$ & $\mathrm{F}$ & G & $\mathrm{H}$ & I & $\mathbf{J}$ & $\mathrm{K}$ & $\mathrm{L}$ \\
\hline DG45 & 1 & 0,670 & & & & D & $\mathrm{E}$ & $\mathrm{F}$ & G & $\mathrm{H}$ & I & $\mathbf{J}$ & $\mathrm{K}$ & L \\
\hline DG55 & 1 & 0.660 & & & & D & $\mathrm{E}$ & $\mathrm{F}$ & G & $\mathrm{H}$ & 1 & $\mathrm{~J}$ & $\mathrm{~K}$ & $\mathrm{~L}$ \\
\hline DG47 & 1 & 0,613 & & & & D & $\mathrm{E}$ & $\mathrm{F}$ & $\mathrm{G}$ & $\mathrm{H}$ & I & $\mathrm{J}$ & $\mathrm{K}$ & $\mathrm{L}$ \\
\hline DG61 & 1 & 0.553 & & & & D & $\mathrm{E}$ & $\mathrm{F}$ & G & $\mathrm{H}$ & I & $\mathrm{J}$ & $\mathrm{K}$ & $\mathrm{L}$ \\
\hline DG43 & I & 0,537 & & & & & $\mathrm{E}$ & $\mathrm{F}$ & G & $\mathrm{H}$ & I & $\mathrm{J}$ & $\mathrm{K}$ & $\mathrm{L}$ \\
\hline DG 120 & 2 & 0.487 & & & & & & $\mathrm{~F}$ & G & $\mathrm{H}$ & I & $\mathrm{J}$ & $\mathrm{K}$ & $\mathrm{L}$ \\
\hline DG44 & 1 & 0,480 & & & & & & $\mathrm{~F}$ & G & $\mathrm{H}$ & I & $\mathrm{J}$ & $\mathrm{K}$ & L \\
\hline DG51 & 1 & 0.457 & & & & & & $\mathrm{~F}$ & G & $\mathrm{H}$ & I & $\mathrm{J}$ & $\mathrm{K}$ & L \\
\hline DG56 & 1 & 0,437 & & & & & & $\mathrm{~F}$ & G & $\mathrm{H}$ & I & $\mathrm{J}$ & $\mathrm{K}$ & $\mathrm{L}$ \\
\hline DG70 & 1 & 0,427 & & & & & & & G & $\mathrm{H}$ & I & $\mathrm{J}$ & $\mathrm{K}$ & $\mathrm{L}$ \\
\hline DG114 & 2 & 0,423 & & & & & & & $\mathrm{G}$ & $\mathrm{H}$ & I & $\mathrm{J}$ & $\mathrm{K}$ & $\mathrm{L}$ \\
\hline DG122 & 2 & 0,380 & & & & & & & & $\mathrm{H}$ & I & $\mathrm{J}$ & $\mathrm{K}$ & $\mathrm{L}$ \\
\hline DG46 & 1 & 0,347 & & & & & & & & & I & $\mathrm{J}$ & $\mathrm{K}$ & $\mathrm{L}$ \\
\hline DG39 & 1 & 0.347 & & & & & & & & & I & $\mathrm{J}$ & $\mathrm{K}$ & $\mathrm{L}$ \\
\hline DG49 & 1 & 0,343 & & & & & & & & & I & $\mathrm{J}$ & $\mathrm{K}$ & L \\
\hline DG112 & 2 & 0.333 & & & & & & & & & I & $\mathrm{J}$ & $\mathrm{K}$ & $\mathrm{L}$ \\
\hline DG52 & 1 & 0,297 & & & & & & & & & I & $\mathrm{J}$ & $\mathrm{K}$ & $\mathrm{L}$ \\
\hline DG60 & 1 & 0,283 & & & & & & & & & & $\mathrm{~J}$ & $K$ & L \\
\hline DG69 & 1 & 0,283 & & & & & & & & & & $\mathrm{~J}$ & $\mathrm{~K}$ & $\mathrm{~L}$ \\
\hline DG40 & 1 & 0.263 & & & & & & & & & & & $\mathrm{~K}$ & $\mathrm{~L}$ \\
\hline DG58 & 1 & 0,250 & & & & & & & & & & & $\mathrm{~K}$ & $\mathrm{~L}$ \\
\hline DG62 & 1 & 0.243 & & & & & & & & & & & $\mathrm{~K}$ & $\mathrm{~L}$ \\
\hline DG138 & 2 & 0,240 & & & & & & & & & & & $\mathrm{~K}$ & $\mathrm{~L}$ \\
\hline DG41 & 1 & 0.240 & & & & & & & & & & & $\mathrm{~K}$ & $\mathrm{~L}$ \\
\hline DG121 & 2 & 0,227 & & & & & & & & & & & $\mathrm{~K}$ & $\mathrm{~L}$ \\
\hline DG50 & 1 & 0,220 & & & & & & & & & & & $\mathrm{~K}$ & $\mathrm{~L}$ \\
\hline DG59 & 1 & 0,187 & & & & & & & & & & & $\mathrm{~K}$ & $\mathrm{~L}$ \\
\hline DG42 & 1 & 0.160 & & & & & & & & & & & $\mathrm{~K}$ & $\mathrm{~L}$ \\
\hline DG71 & 1 & 0,137 & & & & & & & & & & & $\mathrm{~K}$ & $\mathrm{~L}$ \\
\hline DG54 & 1 & 0,103 & & & & & & & & & & & & $\mathrm{~L}$ \\
\hline
\end{tabular}

Região 1: Rjo Negro - Bacia Amazònica

Região 2: Rio Solimões - Bacia Amazònica

Região 3: Litoral Sul - SP 
Tabela 12. Teste de Tukey a 5\% de probabilidade, variável 20 potencial cianogênico nas folhas. $\Delta_{5 \%}=1473,8$.

\begin{tabular}{|c|c|c|c|c|}
\hline Etnov. & Região & Média & $\mathrm{A}$ & B \\
\hline DG70 & 1 & 2017,2 & $A$ & \\
\hline DG48 & 1 & 1868.6 & A & \\
\hline DG125 & 2 & 1714.2 & $A$ & B \\
\hline DG52 & 1 & 1709,1 & $A$ & B \\
\hline DG60 & 1 & 1656.2 & $A$ & B \\
\hline DG114 & 2 & 1537,3 & $A$ & B \\
\hline DG44 & 1 & 1535,2 & $A$ & B \\
\hline DG138 & 2 & 1502.7 & A & B \\
\hline DG43 & 1 & 1485,3 & $A$ & B \\
\hline DG112 & 2 & 1473.0 & A & B \\
\hline DG116 & 2 & 1398.4 & $A$ & B \\
\hline DG54 & 1 & 1382.9 & A & B \\
\hline DG111 & 2 & 1379.6 & $A$ & B \\
\hline DG73 & 1 & 1339.9 & A & B \\
\hline DG69 & 1 & 1323.2 & $A$ & B \\
\hline DG45 & 1 & 1271.1 & A & B \\
\hline DG71 & 1 & 1253,8 & $A$ & B \\
\hline DG50 & 1 & 1241.1 & A & B \\
\hline DG47 & 1 & 1239.3 & A & B \\
\hline DG56 & 1 & 1210,2 & A & B \\
\hline DG133 & 3 & 1191,3 & A & B \\
\hline DG51 & 1 & 1183.0 & A & B \\
\hline DG58 & 1 & 1176.4 & A & B \\
\hline DG121 & 2 & 1161,0 & A & B \\
\hline DG62 & 1 & 1145,8 & $A$ & B \\
\hline DG46 & 1 & 1143,5 & $A$ & B \\
\hline DG41 & 1 & 1131.9 & $A$ & B \\
\hline DG67 & 1 & 1113,9 & $A$ & B \\
\hline DG59 & 1 & 1095,5 & $A$ & B \\
\hline DG124 & 2 & 1075.8 & A & B \\
\hline DG132 & 3 & 1026.8 & $A$ & B \\
\hline MANT & IAC & 1024,6 & A & B \\
\hline DG49 & 1 & 1015,5 & A & B \\
\hline DG134 & 3 & 1010.3 & $A$ & B \\
\hline DG40 & 1 & 942,1 & $A$ & B \\
\hline DG123 & 2 & 916,4 & $A$ & B \\
\hline DG55 & 1 & 901.4 & A & B \\
\hline DG117 & 2 & 893.2 & $A$ & B \\
\hline DG127 & 3 & 879.1 & $A$ & B \\
\hline DG113 & 2 & 856,0 & A & B \\
\hline DG38 & 1 & 834,6 & $A$ & B \\
\hline DG115 & 2 & 798,1 & A & B \\
\hline DG130 & 3 & 787.3 & A & B \\
\hline DG120 & 2 & 784,6 & A & B \\
\hline DG61 & 1 & 779,0 & A & B \\
\hline DG39 & 1 & 761.5 & A & B \\
\hline DG128 & 3 & 751,9 & A & B \\
\hline DG131 & 3 & 736,6 & $\mathrm{~A}$ & B \\
\hline DG68 & 1 & 733,7 & $A$ & B \\
\hline DG119 & 2 & 724,1 & A & B \\
\hline DG42 & 1 & 718,9 & A & B \\
\hline DG126 & 3 & 706,2 & $A$ & B \\
\hline DG118 & 2 & 658.6 & $A$ & B \\
\hline DG129 & 3 & 647.6 & A & B \\
\hline DG122 & 2 & 639.1 & $A$ & B \\
\hline DG65 & 1 & 393,8 & & B \\
\hline
\end{tabular}

Regiāo 1: Rio Negro - Bacia Amazònica Região 2: Rio Solimões - Bacia Amazònica Região 3: Litoral Sul - SP 
Tabela 13. Teste de Tukey a 5\% de probabilidade, variável 21 ácido cianídrico livre nas folhas em $\mathrm{mg} / \mathrm{kg}, \Delta_{5 \%}=272,32$.

\begin{tabular}{|c|c|c|c|c|c|}
\hline Etnov.. & Região & Média & $\mathrm{A}$ & B & $\mathrm{C}$ \\
\hline DG73 & 1 & 389,33 & A & & \\
\hline DG67 & 1 & 346,60 & A & B & \\
\hline DG45 & 1 & 338,01 & A & B & \\
\hline DG117 & 2 & 314.45 & A & B & C \\
\hline MANT & IAC & 311,27 & A & B & C \\
\hline DG133 & 3 & 297,43 & A & B & C \\
\hline DG125 & 2 & 292,31 & A & B & C \\
\hline DG38 & 1 & 271.07 & A & B & C \\
\hline DG51 & 1 & 268,34 & A & B & C \\
\hline DG130 & 3 & 266,61 & A & B & C \\
\hline DG44 & 1 & 264,09 & A & B & C \\
\hline DG111 & 2 & 249.24 & A & B & C \\
\hline DG46 & 1 & 249,10 & A & B & C \\
\hline DG58 & 1 & 233,84 & A & B & C \\
\hline DG134 & 3 & 232,85 & A & B & C \\
\hline DG129 & 3 & 220.22 & A & B & C \\
\hline DG41 & 1 & 215,16 & A & B & C \\
\hline DG39 & 1 & 214,78 & A & B & C \\
\hline DG138 & 2 & 212,90 & A & B & C \\
\hline DG124 & 2 & 196,15 & A & B & C \\
\hline DG70 & 1 & 195,00 & A & B & C \\
\hline DG62 & 1 & 194,95 & A & B & C \\
\hline DG69 & 1 & 192,80 & A & B & C \\
\hline DG50 & 1 & 192.41 & A & B & C \\
\hline DG47 & 1 & 191,19 & A & B & C \\
\hline DG52 & 1 & 188,36 & A & B & C \\
\hline DG112 & 2 & 187,00 & A & B & C \\
\hline DG132 & 3 & 179.83 & A & B & C \\
\hline DG59 & 1 & 179,49 & A & B & C \\
\hline DG118 & 2 & 173.84 & A & B & C \\
\hline DG127 & 3 & 173,28 & A & B & C \\
\hline DG48 & 1 & 173.15 & A & B & C \\
\hline DG121 & 2 & 170.65 & A & B & C \\
\hline DG60 & 1 & 167.38 & A & B & C \\
\hline DG116 & 2 & 164,59 & A & B & C \\
\hline DG128 & 3 & 160.36 & A & B & C \\
\hline DG123 & 2 & 155,05 & A & B & C \\
\hline DG56 & 1 & 154,18 & A & B & $\mathrm{C}$ \\
\hline DG119 & 2 & 153,04 & A & B & C \\
\hline DG71 & 1 & 149,86 & A & B & C \\
\hline DG114 & 2 & 149,51 & A & B & C \\
\hline DG43 & 1 & 144,74 & A & B & C \\
\hline DG68 & 1 & 140,01 & A & B & C \\
\hline DG54 & 1 & 134,51 & A & B & C \\
\hline DG115 & 2 & 131,82 & A & B & C \\
\hline DG40 & 1 & 127.91 & A & B & C \\
\hline DG61 & 1 & 126,28 & A & B & C \\
\hline DG131 & 3 & 125,88 & A & B & C \\
\hline DG42 & 1 & 123,64 & A & B & C \\
\hline DG55 & 1 & 119,75 & A & B & C \\
\hline DG122 & 2 & 119,40 & A & B & C \\
\hline DG126 & 3 & 117.40 & A & B & c \\
\hline DG65 & 1 & 108,61 & & B & C \\
\hline DG49 & 1 & 103,70 & & B & C \\
\hline DG113 & 2 & 96,26 & & B & C \\
\hline DG120 & 2 & 44.16 & & & C \\
\hline
\end{tabular}

Região 1: Rio Negro - Bacia Amazònica Região 2: Rio Solimões - Bacia Amazònica

Região 3: Litoral 5ul - SP 
Tabela 14 . Teste de Tukey a $5 \%$ de probabilidade, variável 23 porcentagem de proteína nas folhas, na base seca, $\Delta_{5 \%}=7,039$.

\begin{tabular}{|c|c|c|c|c|c|}
\hline Etnov. & Região & Média & $\mathrm{A}$ & $\mathrm{B}$ & $\mathrm{C}$ \\
\hline DG44 & 1 & 28.667 & A & & \\
\hline DG43 & 1 & 27,917 & A & & \\
\hline DG1 17 & 2 & 27,627 & A & & \\
\hline DG50 & 1 & 26.723 & A & & \\
\hline DG67 & 1 & 26,470 & A & B & \\
\hline DG62 & 1 & 26,047 & A & B & \\
\hline DG39 & 1 & 25.837 & A & B & \\
\hline DG54 & 1 & 25,657 & A & B & C \\
\hline DG114 & 2 & 25.600 & A & B & C \\
\hline DG123 & 2 & 25,490 & A & B & C \\
\hline DG60 & 1 & 25,433 & A & B & C \\
\hline DG126 & 3 & 25.353 & A & B & C \\
\hline DG55 & 1 & 25.350 & $A$ & B & C \\
\hline DG47 & 1 & 25.333 & A & B & C \\
\hline DG48 & 1 & 25,333 & $A$ & B & $\mathrm{C}$ \\
\hline DG122 & 2 & 25,313 & A & B & C \\
\hline DG71 & 1 & 25.307 & A & B & $\mathrm{C}$ \\
\hline DG42 & 1 & 25,267 & A & B & C \\
\hline DG65 & 1 & 25,230 & A & B & $\mathrm{C}$ \\
\hline DG113 & 2 & 25,207 & A & B & C \\
\hline DG112 & 2 & 25,040 & A & B & C \\
\hline DG115 & 2 & 25,000 & A & B & C \\
\hline DG118 & 2 & 24,997 & A & B & $\mathrm{C}$ \\
\hline DG132 & 3 & 24,970 & A & B & C \\
\hline DG138 & 2 & 24,970 & A & B & $\mathrm{C}$ \\
\hline DG130 & 3 & 24,933 & A & B & $\mathrm{C}$ \\
\hline DG38 & 1 & 24,923 & A & B & C \\
\hline DG127 & 3 & 24.867 & A & B & C \\
\hline DG73 & 1 & 24,830 & A & B & C \\
\hline DG119 & 2 & 24,763 & A & B & C \\
\hline DG116 & 2 & 24,317 & A & B & $\mathrm{C}$ \\
\hline DG68 & 1 & 24,217 & A & B & C \\
\hline DG131 & 3 & 24,210 & A & B & C \\
\hline DG40 & 1 & 24,170 & A & B & $\mathrm{C}$ \\
\hline DG111 & 2 & 24.167 & A & B & C \\
\hline DG46 & 1 & 24,120 & A & B & C \\
\hline DG51 & 1 & 24,053 & A & B & C \\
\hline DG128 & 3 & 23,903 & A & B & $\mathrm{C}$ \\
\hline DG61 & 1 & 23,807 & A & B & C \\
\hline DG 120 & 2 & 23,777 & A & B & C \\
\hline DG56 & 1 & 23,670 & A & B & C \\
\hline DG125 & 2 & 23,620 & A & B & C \\
\hline DG59 & 1 & 23,523 & A & B & C \\
\hline DG69 & 1 & 23,497 & A & B & C \\
\hline DG41 & 1 & 23,327 & A & B & $\mathrm{C}$ \\
\hline DG133 & 3 & 23,063 & A & B & C \\
\hline DG134 & 3 & 23.010 & A & B & $\mathrm{C}$ \\
\hline DG45 & 1 & 22,810 & A & B & $\mathrm{C}$ \\
\hline DG58 & 1 & 22.313 & A & B & $\mathrm{C}$ \\
\hline MANT & IAC & 22,300 & A & B & C \\
\hline DG52 & 1 & 22,300 & A & B & C \\
\hline DG124 & 2 & 22.253 & A & B & $\mathrm{C}$ \\
\hline DG121 & 2 & 21.707 & A & B & C \\
\hline DG70 & 1 & 21,647 & A & B & C \\
\hline DG129 & 3 & 19,540 & & B & $\mathrm{C}$ \\
\hline DG49 & 1 & 18,660 & & & C \\
\hline
\end{tabular}

Região 1: Rio Negro - Bacia Amazònica

Região 2: Rio Solimões - Bacia Amazônica

Regiảo 3: Litoral Sul - SP 
Tabela 15. Teste de Tukey a 5\% de probabilidade, variável 24 porcentagem de matéria graxa nas folhas. na base seca, $\Delta_{5 \%}=3,5572$.

\begin{tabular}{|c|c|c|c|c|c|c|c|c|}
\hline Etnov. & Região & Média & A & $\mathrm{B}$ & $\mathrm{C}$ & $\mathrm{D}$ & $E$ & $\mathrm{~F}$ \\
\hline DG112 & 2 & 10,367 & A & & & & & \\
\hline DG71 & 1 & 10,157 & A & B & & & & \\
\hline DG120 & 2 & 9,490 & A & B & C & & & \\
\hline DG130 & 3 & 9.240 & A & B & $\mathrm{C}$ & D & & \\
\hline DG111 & 2 & 8,507 & A & B & $\mathrm{C}$ & $\mathrm{D}$ & $E$ & \\
\hline DG68 & 1 & 7,877 & A & B & $\mathrm{C}$ & $\mathrm{D}$ & $E$ & $\mathrm{~F}$ \\
\hline DG45 & 1 & 7,633 & A & B & $\mathrm{C}$ & D & $\mathrm{E}$ & $\mathrm{F}$ \\
\hline DG51 & 1 & 7,613 & A & $\mathrm{B}$ & $\mathrm{C}$ & $\mathrm{D}$ & $E$ & $\mathrm{~F}$ \\
\hline DG128 & 3 & 7,470 & A & $\mathrm{B}$ & $\mathrm{C}$ & D & $E$ & $\mathrm{~F}$ \\
\hline DG62 & 1 & 7,403 & A & B & $\mathrm{C}$ & D & $E$ & $\mathrm{~F}$ \\
\hline DG44 & 1 & 7,300 & A & B & $\mathrm{C}$ & $\mathrm{D}$ & $E$ & $\mathrm{~F}$ \\
\hline DG41 & 1 & 7.280 & A & B & C & D & $E$ & $\mathrm{~F}$ \\
\hline DG55 & 1 & 7.267 & A & B & C & D & $E$ & $\mathrm{~F}$ \\
\hline DG117 & 2 & 7.250 & $\mathrm{~A}$ & B & C & $\mathrm{D}$ & $E$ & $\mathrm{~F}$ \\
\hline DG54 & 1 & 7,153 & $A$ & B & $\mathrm{C}$ & $\mathrm{D}$ & $\mathrm{E}$ & $\mathrm{F}$ \\
\hline DG138 & 2 & 7,007 & A & B & $\mathrm{C}$ & $\mathrm{D}$ & $E$ & $F$ \\
\hline DG126 & 3 & 6,990 & A & B & $\mathrm{C}$ & $\mathrm{D}$ & $\mathrm{E}$ & $\mathrm{F}$ \\
\hline DG114 & 2 & 6,970 & A & B & $\mathrm{C}$ & D & $E$ & $\mathrm{~F}$ \\
\hline DG73 & 1 & 6,923 & $\mathrm{~A}$ & $\mathrm{~B}$ & C & $\mathrm{D}$ & $E$ & $F$ \\
\hline DG69 & 1 & 6,853 & A & B & $\mathrm{C}$ & D & $\mathrm{E}$ & $\mathrm{F}$ \\
\hline DG47 & 1 & 6,810 & $\mathrm{~A}$ & B & $\mathrm{C}$ & $\mathrm{D}$ & $E$ & $\mathrm{~F}$ \\
\hline DG115 & 2 & 6,797 & & B & C & D & $\mathrm{E}$ & $\mathrm{F}$ \\
\hline DG123 & 2 & 6,787 & & B & $\mathrm{C}$ & D & $E$ & $\mathrm{~F}$ \\
\hline DG125 & 2 & 6.773 & & $\mathrm{~B}$ & C & $\mathrm{D}$ & $\mathrm{E}$ & $\mathrm{F}$ \\
\hline DG134 & 3 & 6,770 & & B & C & $\mathrm{D}$ & $\mathrm{E}$ & $F$ \\
\hline DG38 & 1 & 6,690 & & B & C & D & $\mathrm{E}$ & $F$ \\
\hline DG59 & 1 & 6,653 & & B & C & $\mathrm{D}$ & $E$ & $F$ \\
\hline DG67 & 1 & 6,607 & & B & C & $\mathrm{D}$ & $E$ & $\mathrm{~F}$ \\
\hline DG39 & $i$ & 6,383 & & & $\mathrm{C}$ & $\mathrm{D}$ & $\mathrm{E}$ & $\mathrm{F}$ \\
\hline DG65 & 1 & 6.373 & & & C & D & $\mathrm{E}$ & $F$ \\
\hline DG121 & 2 & 6,333 & & & C & D & $E$ & $F$ \\
\hline DG122 & 2 & 6.310 & & & C & D & $E$ & $F$ \\
\hline DG61 & 1 & 6,297 & & & C & D & $E$ & $F$ \\
\hline DG119 & 2 & 6.247 & & & C & D & $E$ & $\mathrm{~F}$ \\
\hline DG70 & 1 & 6,217 & & & C & D & $E$ & $\mathrm{~F}$ \\
\hline DG116 & 2 & 6,203 & & & C & $\mathrm{D}$ & $E$ & $F$ \\
\hline DG118 & 2 & 6,183 & & & C & D & $E$ & $\mathrm{~F}$ \\
\hline DG52 & 1 & 6.113 & & & C & D & $E$ & $F$ \\
\hline DG132 & 3 & 6,040 & & & C & D & $\mathrm{E}$ & $\mathrm{F}$ \\
\hline DG129 & 3 & 6.017 & & & C & D & $E$ & $\mathrm{~F}$ \\
\hline DG124 & 2 & 6,017 & & & C & D & $\mathrm{E}$ & $\mathrm{F}$ \\
\hline DG133 & 3 & 6.003 & & & $\mathrm{C}$ & D & $\bar{E}$ & $F$ \\
\hline DG58 & 1 & 5,977 & & & C & D & $E$ & $F$ \\
\hline MANT & IAC & 5,977 & & & C & D & $E$ & $\mathrm{~F}$ \\
\hline DG127 & 3 & 5,883 & & & & D & $E$ & $\mathrm{~F}$ \\
\hline DG40 & 1 & 5.857 & & & & D & $E$ & $\mathrm{~F}$ \\
\hline DG50 & 1 & 5,813 & & & & $\mathrm{D}$ & $E$ & $F$ \\
\hline DG56 & 1 & 5,713 & & & & D & $E$ & $\mathrm{~F}$ \\
\hline DG48 & 1 & 5,677 & & & & & $\mathrm{E}$ & $F$ \\
\hline DG113 & 2 & 5,670 & & & & & $E$ & $\mathrm{~F}$ \\
\hline DG43 & 1 & 5,417 & & & & & $E$ & $\mathrm{~F}$ \\
\hline DG46 & 1 & 5,383 & & & & & $\mathrm{E}$ & $\mathrm{F}$ \\
\hline DG49 & 1 & 5,380 & & & & & $\mathrm{E}$ & $\mathrm{F}$ \\
\hline DG42 & 1 & 5.177 & & & & & $E$ & $\mathrm{~F}$ \\
\hline DG60 & 1 & 4,987 & & & & & $E$ & $F$ \\
\hline DG131 & 3 & 4.870 & & & & & & $\mathrm{~F}$ \\
\hline
\end{tabular}

Região 1: Rio Negro - Bacia Amazònica

Região 2: Rio Solimões - Bacia Amazònica

Região 3: Litoral Sul - SP 
Tabela 16. Teste de Tukey a $5 \%$ de probabilidade, variável 25 porcentagem de cinzas nas folhas. na base seca, $\Delta_{5 \%}=3,209$.

\begin{tabular}{|c|c|c|c|c|c|c|c|c|c|}
\hline Etnov. & Região & Média & $\mathrm{A}$ & B & C & $\mathrm{D}$ & $E$ & $\mathrm{~F}$ & $\mathrm{G}$ \\
\hline DG130 & 3 & 10.873 & A & & & & & & \\
\hline DG115 & 2 & 10,640 & A & B & & & & & \\
\hline DG126 & 3 & 10,057 & A & B & C & & & & \\
\hline DG59 & 1 & 9,500 & A & B & C & D & & & \\
\hline DG 128 & 3 & 8,730 & A & B & C & D & E & & \\
\hline DG50 & 1 & 8,650 & A & B & C & D & $\mathrm{E}$ & $\mathrm{F}$ & \\
\hline DG49 & 1 & 8.603 & A & B & C & D & $\mathrm{E}$ & $\mathrm{F}$ & \\
\hline DG133 & 3 & 8,343 & A & B & C & D & E & $\mathrm{F}$ & G \\
\hline DG127 & 3 & 8.310 & A & B & C & D & E & $\mathrm{F}$ & G \\
\hline DG117 & 2 & 8.287 & A & B & C & D & $\mathrm{E}$ & $\mathrm{F}$ & G \\
\hline DG51 & I & 8.287 & A & B & C & D & $\mathrm{E}$ & $\mathrm{F}$ & G \\
\hline DG69 & 1 & 8.190 & A & B & $\mathrm{C}$ & D & $\mathrm{E}$ & $\mathrm{F}$ & $\mathrm{G}$ \\
\hline DG119 & 2 & 8,140 & A & B & $\mathrm{C}$ & D & $\mathrm{E}$ & $\mathrm{F}$ & G \\
\hline DG124 & 2 & 8,107 & A & B & $\mathrm{C}$ & D & $\mathrm{E}$ & $\mathrm{F}$ & G \\
\hline DG120 & 2 & 8.070 & A & B & C & D & E & $\mathrm{F}$ & G \\
\hline DG47 & 1 & 8,003 & A & B & C & D & $\mathrm{E}$ & $\mathrm{F}$ & G \\
\hline DG68 & I & 7,980 & A & B & C & D & $\mathrm{E}$ & $\mathrm{F}$ & G \\
\hline DG44 & 1 & 7,970 & A & B & C & D & E & $\mathrm{F}$ & G \\
\hline DG55 & 1 & 7,903 & A & B & $\mathrm{C}$ & D & E & $\mathrm{F}$ & G \\
\hline DG46 & 1 & 7,703 & A & B & C & D & E & $\mathrm{F}$ & G \\
\hline DG118 & 2 & 7,600 & & B & C & D & E & $\mathrm{F}$ & G \\
\hline DG129 & 3 & 7,593 & & B & $\mathrm{C}$ & D & $\mathrm{E}$ & $\mathrm{F}$ & G \\
\hline DG67 & 1 & 7,467 & & B & C & D & E & $\mathrm{F}$ & G \\
\hline DG40 & 1 & 7,357 & & & C & D & E & $\mathrm{F}$ & G \\
\hline DG54 & 1 & 7,347 & & & $\mathrm{C}$ & D & $\mathrm{E}$ & $\mathrm{F}$ & $\mathrm{G}$ \\
\hline DG39 & 1 & 7.320 & & & C & D & $\mathrm{E}$ & $\mathrm{F}$ & G \\
\hline DG71 & 1 & 7,290 & & & C & D & E & $\mathrm{F}$ & G \\
\hline DG138 & 2 & 7,260 & & & $\mathrm{C}$ & D & $\mathrm{E}$ & $\mathrm{F}$ & $\mathrm{G}$ \\
\hline DG52 & 1 & 7,200 & & & C & D & E & $\mathrm{F}$ & G \\
\hline DG65 & 1 & 7.183 & & & C & D & $\mathrm{E}$ & $\mathrm{F}$ & G \\
\hline DG125 & 2 & 7,167 & & & $\mathrm{C}$ & D & $\mathrm{E}$ & $\mathrm{F}$ & G \\
\hline DG134 & 3 & 7,127 & & & C & D & $\mathrm{E}$ & $\mathrm{F}$ & G \\
\hline DG123 & 2 & 7,097 & & & C & D & $\mathrm{E}$ & $\mathrm{F}$ & G \\
\hline DG112 & 2 & 7,057 & & & C & D & E & $\mathrm{F}$ & G \\
\hline DG70 & 1 & 6,987 & & & C & D & $\mathrm{E}$ & $\mathrm{F}$ & G \\
\hline DG132 & 3 & 6,937 & & & C & D & $\mathrm{E}$ & $\mathrm{F}$ & G \\
\hline MANT & IAC & 6,893 & & & C & D & E & $\mathrm{F}$ & G \\
\hline DG42 & 1 & 6,860 & & & C & D & $\mathrm{E}$ & $\mathrm{F}$ & G \\
\hline DG122 & 2 & 6,773 & & & & D & E & $\mathrm{F}$ & G \\
\hline DG58 & 1 & 6,770 & & & & D & $\mathrm{E}$ & $\mathrm{F}$ & G \\
\hline DG113 & 2 & 6.747 & & & & D & E & $\mathrm{F}$ & G \\
\hline DG60 & 1 & 6,737 & & & & D & E & $\mathrm{F}$ & G \\
\hline DG41 & i & 6,580 & & & & D & $\mathrm{E}$ & $\mathrm{F}$ & G \\
\hline DG121 & 2 & 6,453 & & & & D & E & $\mathrm{F}$ & G \\
\hline DG61 & 1 & 6,430 & & & & D & E & $\mathrm{F}$ & G \\
\hline DG45 & 1 & 6,420 & & & & D & E & $\mathrm{F}$ & G \\
\hline DG62 & 1 & 6,333 & & & & D & E & $\mathrm{F}$ & G \\
\hline DG73 & I & 6,310 & & & & D & $\mathrm{E}$ & $\mathrm{F}$ & G \\
\hline DG48 & 1 & 6,287 & & & & & $\mathrm{E}$ & $\mathrm{F}$ & G \\
\hline DG43 & 1 & 6,197 & & & & & E & $\mathrm{F}$ & G \\
\hline DG111 & 2 & 6,173 & & & & & $\mathrm{E}$ & $\mathrm{F}$ & G \\
\hline DG131 & 3 & 6,123 & & & & & E & $\mathrm{F}$ & G \\
\hline DG56 & 1 & 6,087 & & & & & E & $\mathrm{F}$ & G \\
\hline DG38 & 1 & 5.950 & & & & & $\mathrm{E}$ & $\mathrm{F}$ & G \\
\hline DG114 & 2 & 5.520 & & & & & & $\mathrm{~F}$ & G \\
\hline DG116 & 2 & 5,370 & & & & & & & G \\
\hline
\end{tabular}

Região 1: Rio Negro - Bacia Amazònica

Região 2: Rio Solimões - Bacia Amazònica

Região 3: Litoral 5ul - SP 
Tabela 17. Teste de Tukey a 5\% de probabilidade, variável 26 porcentagem de fibras nas folhas. na base seca, $\Delta_{5 \%}=3,21$.

\begin{tabular}{|c|c|c|c|c|c|c|c|c|c|c|c|c|c|}
\hline Etnov. & Região & Média & $\mathrm{A}$ & B & $\mathrm{C}$ & $\mathrm{D}$ & $\bar{E}$ & $\mathrm{~F}$ & $\mathrm{G}$ & $\mathrm{H}$ & I & $\mathrm{J}$ & $\bar{K}$ \\
\hline DG117 & 2 & 23,103 & $\mathrm{~A}$ & & & & & & & & & & \\
\hline DG52 & 1 & 21.437 & $\mathrm{~A}$ & B & & & & & & & & & \\
\hline DG116 & 2 & 20,480 & $\mathrm{~A}$ & B & C & & & & & & & & \\
\hline DG50 & I & 20.337 & $\mathrm{~A}$ & B & $\mathrm{C}$ & D & & & & & & & \\
\hline DG55 & 1 & 19,537 & & B & $\mathrm{C}$ & $\mathrm{D}$ & E & & & & & & \\
\hline DG54 & 1 & 19,443 & & B & C & $\mathrm{D}$ & E & & & & & & \\
\hline DG118 & 2 & 19.420 & & B & $\mathrm{C}$ & $\mathrm{D}$ & E & & & & & & \\
\hline DG43 & 1 & 19.303 & & B & $\mathrm{C}$ & $\mathrm{D}$ & E & $\mathrm{F}$ & & & & & \\
\hline DG68 & 1 & 19,257 & & $\mathrm{~B}$ & $\mathrm{C}$ & $\mathrm{D}$ & E & $\mathrm{F}$ & & & & & \\
\hline DG111 & 2 & 19,123 & & B & $\mathrm{C}$ & $\mathrm{D}$ & E & $\mathrm{F}$ & & & & & \\
\hline DG123 & 2 & 18,927 & & B & $\mathrm{C}$ & $\mathrm{D}$ & $\mathrm{E}$ & $\mathrm{F}$ & G & & & & \\
\hline DG65 & 1 & 18.870 & & B & $\mathrm{C}$ & $\mathrm{D}$ & E & $\mathrm{F}$ & G & & & & \\
\hline DG124 & 2 & 18.743 & & B & $\mathrm{C}$ & $\mathrm{D}$ & E & $\mathrm{F}$ & G & & & & \\
\hline DG56 & 1 & 18.623 & & B & $\mathrm{C}$ & $\mathrm{D}$ & E & $F$ & G & $\mathrm{H}$ & & & \\
\hline DG138 & 2 & 18.570 & & B & $\mathrm{C}$ & $\mathrm{D}$ & E & $\mathrm{F}$ & G & $\mathrm{H}$ & & & \\
\hline DG127 & 3 & 18.550 & & B & $\mathrm{C}$ & $\mathrm{D}$ & E & $\mathrm{F}$ & G & $\mathrm{H}$ & & & \\
\hline DG40 & 1 & 18,457 & & B & C & D & E & $\mathrm{F}$ & G & $\mathrm{H}$ & & & \\
\hline DG44 & 1 & 18,353 & & B & $\mathrm{C}$ & D & E & $\mathrm{F}$ & G & $\mathrm{H}$ & 1 & & \\
\hline DG73 & 1 & 18,293 & & B & $\mathrm{C}$ & $\mathrm{D}$ & E & $\mathrm{F}$ & G & $\mathrm{H}$ & I & & \\
\hline DG114 & 2 & 18.240 & & B & $\mathrm{C}$ & $\mathrm{D}$ & E & $\mathrm{F}$ & G & $\mathrm{H}$ & I & & \\
\hline DG121 & 2 & 18,197 & & & $\mathrm{C}$ & $\mathrm{D}$ & E & $\mathrm{F}$ & G & $\mathrm{H}$ & I & & \\
\hline DG46 & 1 & 18,127 & & & $\mathrm{C}$ & D & $\mathrm{E}$ & $\mathrm{F}$ & G & $\mathrm{H}$ & I & & \\
\hline DG129 & 3 & 18,083 & & & $\mathrm{C}$ & D & E & $\mathrm{F}$ & G & $\mathrm{H}$ & I & & \\
\hline DG128 & 3 & 18.043 & & & $\mathrm{C}$ & D & $\mathrm{E}$ & $\mathrm{F}$ & G & $\mathrm{H}$ & I & & \\
\hline DG132 & 3 & 17,983 & & & C & D & $\mathrm{E}$ & $\mathrm{F}$ & $\mathrm{G}$ & $\mathrm{H}$ & I & & \\
\hline DG120 & 2 & 17,967 & & & $\mathrm{C}$ & $\mathrm{D}$ & E & $\mathrm{F}$ & G & $\mathrm{H}$ & I & & \\
\hline DG133 & 3 & 17,913 & & & C & D & E & $\mathrm{F}$ & G & $\mathrm{H}$ & I & & \\
\hline DG59 & 1 & 17,870 & & & C & D & $E$ & $\mathrm{~F}$ & G & $\mathrm{H}$ & I & & \\
\hline DG42 & 1 & 17,870 & & & $\mathrm{C}$ & D & E & $\mathrm{F}$ & G & $\mathrm{H}$ & I & & \\
\hline DG69 & I & 17,820 & & & $\mathrm{C}$ & D & E & $\mathrm{F}$ & $\mathrm{G}$ & $\mathrm{H}$ & I & $\mathrm{J}$ & \\
\hline DG62 & 1 & 17.790 & & & $\mathrm{C}$ & D & E & $\mathrm{F}$ & $\mathrm{G}$ & $\mathrm{H}$ & I & $\mathrm{J}$ & \\
\hline DG115 & 2 & 17.783 & & & $\mathrm{C}$ & D & E & $\mathrm{F}$ & G & $\mathrm{H}$ & I & $\mathrm{J}$ & \\
\hline DG58 & 1 & 17,557 & & & C & D & E & $\mathrm{F}$ & G & $\mathrm{H}$ & I & $\mathrm{J}$ & \\
\hline DG130 & 3 & 17,533 & & & C & D & E & $\mathrm{F}$ & G & $\mathrm{H}$ & I & $\mathrm{J}$ & $\mathrm{K}$ \\
\hline DG125 & 2 & 17,530 & & & C & D & E & $\mathrm{F}$ & G & $\mathrm{H}$ & I & $\mathrm{J}$ & $\mathrm{K}$ \\
\hline DG70 & 1 & 17.420 & & & $\mathrm{C}$ & D & E & $\mathrm{F}$ & G & $\mathrm{H}$ & 1 & $\mathrm{~J}$ & $\mathrm{~K}$ \\
\hline DG131 & 3 & 17,407 & & & $\mathrm{C}$ & D & E & $\mathrm{F}$ & $\mathrm{G}$ & $\mathrm{H}$ & I & $\mathrm{J}$ & $\mathrm{K}$ \\
\hline DG126 & 3 & 17,283 & & & $\mathrm{C}$ & D & $E$ & $F$ & G & $\mathrm{H}$ & I & $\mathrm{J}$ & $\mathrm{K}$ \\
\hline DG49 & 1 & 17,263 & & & & D & $E$ & $\mathrm{~F}$ & G & $\mathrm{H}$ & I & $\mathrm{J}$ & $\mathrm{K}$ \\
\hline DG45 & 1 & 17.260 & & & & D & E & $F$ & G & $\mathrm{H}$ & I & $\mathrm{J}$ & $\mathrm{K}$ \\
\hline DG60 & 1 & 17,237 & & & & D & E & $\mathrm{F}$ & G & $\mathrm{H}$ & I & $\mathrm{J}$ & $\mathrm{K}$ \\
\hline DG71 & 1 & 17,220 & & & & D & E & $\mathrm{F}$ & G & $\mathrm{H}$ & I & $\mathrm{J}$ & $\mathrm{K}$ \\
\hline DG47 & 1 & 17,213 & & & & D & $E$ & $\mathrm{~F}$ & $\mathrm{G}$ & $\mathrm{H}$ & I & $\mathrm{J}$ & $\mathrm{K}$ \\
\hline MANT & IAC & 17.133 & & & & $\mathrm{D}$ & E & $\mathrm{F}$ & $\mathrm{G}$ & $\mathrm{H}$ & I & $\mathrm{J}$ & $\mathrm{K}$ \\
\hline DG113 & 2 & 16,983 & & & & & $\mathrm{E}$ & $\mathrm{F}$ & $\mathrm{G}$ & $\mathrm{H}$ & I & $\mathrm{J}$ & $\mathrm{K}$ \\
\hline DG51 & 1 & 16,963 & & & & & $\mathrm{E}$ & $\mathrm{F}$ & $\mathrm{G}$ & $\mathrm{H}$ & I & $\mathrm{J}$ & $\mathrm{K}$ \\
\hline DG119 & 2 & 16,843 & & & & & $\mathrm{E}$ & $\mathrm{F}$ & $\mathrm{G}$ & $\mathrm{H}$ & I & $\mathrm{J}$ & $\mathrm{K}$ \\
\hline DG67 & 1 & 16.663 & & & & & $\mathrm{E}$ & $\mathrm{F}$ & G & $\mathrm{H}$ & I & $\mathrm{J}$ & $\mathrm{K}$ \\
\hline DG134 & 3 & 16,137 & & & & & & $\mathrm{~F}$ & G & $\mathrm{H}$ & I & $\mathrm{J}$ & $\mathrm{K}$ \\
\hline DG61 & 1 & 15,887 & & & & & & & G & $\mathrm{H}$ & I & $\mathrm{J}$ & $\mathrm{K}$ \\
\hline DG48 & 1 & 15,877 & & & & & & & G & $\mathrm{H}$ & I & $\mathrm{J}$ & $\mathrm{K}$ \\
\hline DG38 & 1 & 15.487 & & & & & & & & $\mathrm{H}$ & I & $J$ & $\mathrm{~K}$ \\
\hline DG112 & 2 & 15,453 & & & & & & & & $\mathrm{H}$ & I & $\mathrm{J}$ & $\mathrm{K}$ \\
\hline DG122 & 2 & 15.190 & & & & & & & & & I & $\mathrm{J}$ & $\mathrm{K}$ \\
\hline DG39 & 1 & 14,613 & & & & & & & & & & $\mathrm{~J}$ & $\mathrm{~K}$ \\
\hline DG41 & 1 & 14.340 & & & & & & & & & & & $\mathrm{~K}$ \\
\hline
\end{tabular}

Região 1: Rio Negro - Bacia Amazónica

Região 2: Rio Solimões - Bacia Amazònica

Região 3: Litoral 5 ul - SP 
Tabela 18 . Teste de Tukey a $5 \%$ de probabilidade, variável 28 teor de umidade no caule, $\Delta_{5 \%}=15,012$.

\begin{tabular}{|c|c|c|c|c|c|}
\hline Etnov. & Região & Média & $\mathrm{A}$ & $\mathrm{B}$ & $\mathrm{C}$ \\
\hline DG133 & 3 & 72,327 & A & & \\
\hline DG128 & 3 & 71,923 & A & B & \\
\hline DG131 & 3 & 69,827 & A & B & C \\
\hline DG69 & 1 & 69.467 & A & B & C \\
\hline DG71 & 1 & 69,390 & A & B & C \\
\hline DG45 & 1 & 68,950 & A & B & C \\
\hline DG55 & 1 & 68,910 & A & B & C \\
\hline DG38 & 1 & 68.793 & A & B & C \\
\hline DG114 & 2 & 68,653 & A & B & C \\
\hline DG59 & 1 & 67,993 & A & B & C \\
\hline DG56 & 1 & 67.420 & $A$ & B & C \\
\hline DG67 & 1 & 66.953 & A & B & C \\
\hline DG68 & 1 & 66.543 & $\mathrm{~A}$ & B & $\mathrm{C}$ \\
\hline DG46 & 1 & 66.487 & A & B & C \\
\hline DG50 & 1 & 66.483 & A & B & C \\
\hline DG117 & 2 & 66.453 & A & B & C \\
\hline DG134 & 3 & 66,350 & $A$ & B & $\mathrm{C}$ \\
\hline DG118 & 2 & 66.337 & A & B & C \\
\hline DG124 & 2 & 66,170 & $\mathrm{~A}$ & B & $\mathrm{C}$ \\
\hline DG115 & 2 & 66.133 & $\mathrm{~A}$ & B & $\mathrm{C}$ \\
\hline DG42 & 1 & 65,217 & A & B & C \\
\hline DG132 & 3 & 65,110 & A & B & C \\
\hline DG116 & 2 & 65,097 & A & B & C \\
\hline DG48 & 1 & 64.753 & A & B & C \\
\hline DG52 & 1 & 64,593 & $A$ & B & $\mathrm{C}$ \\
\hline DG61 & 1 & 64.560 & A & B & C \\
\hline DG41 & 1 & 64,407 & A & B & $\mathrm{C}$ \\
\hline MANT & IAC & 64.370 & $\mathrm{~A}$ & B & $\mathrm{C}$ \\
\hline DG65 & 1 & 64,083 & A & B & C \\
\hline DG62 & 1 & 64.080 & $\mathrm{~A}$ & B & $\mathrm{C}$ \\
\hline DG73 & 1 & 63,937 & $A$ & B & $\mathrm{C}$ \\
\hline DG126 & 3 & 63.930 & A & B & C \\
\hline DG39 & 1 & 63,647 & A & B & C \\
\hline DG130 & 3 & 63.100 & A & B & C \\
\hline DG120 & 2 & 63,090 & A & B & C \\
\hline DG60 & 1 & 63.040 & A & B & $\mathrm{C}$ \\
\hline DG43 & 1 & 62,110 & A & $\mathrm{B}$ & $\mathrm{C}$ \\
\hline DG129 & 3 & 62.103 & $A$ & B & $\mathrm{C}$ \\
\hline DG54 & 1 & 62,090 & A & B & C \\
\hline DG51 & 1 & 62.050 & A & B & C \\
\hline DG119 & 2 & 61,820 & $\mathrm{~A}$ & B & $\mathrm{C}$ \\
\hline DG70 & 1 & 61.740 & $\mathrm{~A}$ & $\mathrm{~B}$ & $\mathrm{C}$ \\
\hline DG40 & 1 & 61,643 & A & B & C \\
\hline DG49 & 1 & 61.317 & A & B & C \\
\hline DG127 & 3 & 60,670 & A & B & C \\
\hline DG125 & 2 & 60.437 & $\mathrm{~A}$ & B & $\mathrm{C}$ \\
\hline DG58 & 1 & 60,117 & $\mathrm{~A}$ & B & $\mathrm{C}$ \\
\hline DG44 & 1 & 59.960 & $\mathrm{~A}$ & B & $\mathrm{C}$ \\
\hline DG138 & 2 & 59,757 & A & B & $\mathrm{C}$ \\
\hline DG121 & 2 & 59.350 & $\mathrm{~A}$ & B & $\mathrm{C}$ \\
\hline DG122 & 2 & 59,050 & A & B & C \\
\hline DG111 & 2 & 58.560 & $\mathrm{~A}$ & B & $\mathrm{C}$ \\
\hline DG47 & 1 & 57,007 & & B & $\mathrm{C}$ \\
\hline DG113 & 2 & 56.830 & & & C \\
\hline DG112 & 2 & 56,147 & & & C \\
\hline DG123 & 2 & 55,247 & & & C \\
\hline
\end{tabular}

Região 1: Rio Neggro - Bacia Amazònica

Região 2: Rio Solimões - Bacia Amazònica

Região 3: Litoral 5ul - SP 
Tabela 19. Teste de Tukey a 5\% de probabilidade, variável 29 porcentagem de cinzas no caule, na base seca. $\Delta_{5 \%}=1,044$.

\begin{tabular}{|c|c|c|c|c|c|c|c|c|c|c|c|c|c|c|c|c|c|c|c|c|c|c|c|c|c|c|}
\hline Etnov & Rg. & Med & A & B & C & D & $\mathrm{E}$ & $\mathrm{F}$ & G & $\mathrm{H}$ & I & $\mathrm{J}$ & $\mathrm{K}$ & $\mathrm{L}$ & $\mathrm{M}$ & $\mathbf{N}$ & $\mathrm{O}$ & $\mathrm{P}$ & $\mathrm{Q}$ & $\mathrm{R}$ & $S$ & $T$ & $\mathrm{U}$ & $\mathrm{V}$ & $W$ & $\bar{X}$ \\
\hline DG38 & 1 & 8,447 & A & & & & & & & & & & & & & & & & & & & & & & & \\
\hline DG54 & 1 & 8.153 & A & B & & & & & & & & & & & & & & & & & & & & & & \\
\hline DG48 & 1 & 7,210 & & B & C & & & & & & & & & & & & & & & & & & & & & \\
\hline DG41 & 1 & 6,817 & & & C & D & & & & & & & & & & & & & & & & & & & & \\
\hline DG120 & 2 & 6,527 & & & C & D & $\mathrm{E}$ & & & & & & & & & & & & & & & & & & & \\
\hline DG61 & 1 & 6,430 & & & C & D & E & F & & & & & & & & & & & & & & & & & & \\
\hline DG122 & 2 & 6,397 & & & C & D & $\mathrm{E}$ & $\mathrm{F}$ & & & & & & & & & & & & & & & & & & \\
\hline DG119 & 2 & 6,363 & & & C & D & $\mathrm{E}$ & $\mathrm{F}$ & & & & & & & & & & & & & & & & & & \\
\hline DG49 & 1 & 6,293 & & & C & D & E & $\mathrm{F}$ & G & & & & & & & & & & & & & & & & & \\
\hline DG128 & 3 & 6,110 & & & & $\mathrm{D}$ & E & $\mathrm{F}$ & G & $\mathrm{H}$ & & & & & & & & & & & & & & & & \\
\hline DG62 & 1 & 5,967 & & & & D & E & $\mathrm{F}$ & G & $\mathrm{H}$ & I & & & & & & & & & & & & & & & \\
\hline DG131 & 3 & 5.950 & & & & D & E & $\mathrm{F}$ & G & $\mathrm{H}$ & I & & & & & & & & & & & & & & & \\
\hline DG55 & 1 & 5.940 & & & & D & E & F & G & $\mathrm{H}$ & I & & & & & & & & & & & & & & & \\
\hline DG124 & 2 & 5.910 & & & & D & E & F & G & $\mathrm{H}$ & I & & & & & & & & & & & & & & & \\
\hline DG134 & 3 & 5,803 & & & & D & $\mathrm{E}$ & $\mathrm{F}$ & G & $\mathrm{H}$ & I & $\mathrm{J}$ & & & & & & & & & & & & & & \\
\hline DG121 & 2 & 5,757 & & & & & $\mathrm{E}$ & $\mathrm{F}$ & G & $\mathrm{H}$ & I & $\mathrm{J}$ & $\mathrm{K}$ & & & & & & & & & & & & & \\
\hline DG42 & 1 & 5,710 & & & & & E & $\mathrm{F}$ & G & $\mathrm{H}$ & I & $\mathrm{J}$ & $\mathrm{K}$ & $\mathrm{L}$ & & & & & & & & & & & & \\
\hline DG117 & 2 & 5.637 & & & & & $\mathrm{E}$ & F & G & $\mathrm{H}$ & I & $\mathrm{J}$ & $\mathrm{K}$ & $\mathrm{L}$ & M & & & & & & & & & & & \\
\hline DG71 & 1 & 5,623 & & & & & E & $\mathrm{F}$ & G & $\mathrm{H}$ & I & J & $\mathrm{K}$ & $\mathrm{L}$ & M & & & & & & & & & & & \\
\hline DG67 & 1 & 5,610 & & & & & E & $\mathrm{F}$ & G & $\mathrm{H}$ & I & $\mathrm{J}$ & $\mathrm{K}$ & $\mathrm{L}$ & $\mathrm{M}$ & & & & & & & & & & & \\
\hline DG52 & 1 & 5,487 & & & & & $\mathrm{E}$ & $\mathrm{F}$ & G & $\mathrm{H}$ & I & $\mathrm{J}$ & $\mathrm{K}$ & $\mathrm{L}$ & $\mathrm{M}$ & $\mathbf{N}$ & & & & & & & & & & \\
\hline DG39 & 1 & 5,437 & & & & & & $\mathrm{~F}$ & G & $\mathrm{H}$ & I & $\mathrm{J}$ & $\mathrm{K}$ & $\mathrm{L}$ & M & $\mathrm{N}$ & $\mathrm{O}$ & & & & & & & & & \\
\hline DG40 & 1 & 5,387 & & & & & & $\mathrm{~F}$ & G & $\mathrm{H}$ & I & $\mathrm{J}$ & $\mathrm{K}$ & $\mathrm{L}$ & $M$ & $\mathbf{N}$ & $\mathrm{O}$ & & & & & & & & & \\
\hline DG70 & 1 & 5,317 & & & & & & & G & $\mathrm{H}$ & I & $\mathrm{J}$ & $\mathrm{K}$ & $\mathrm{L}$ & M & $\mathrm{N}$ & $\mathrm{O}$ & P & & & & & & & & \\
\hline DG127 & 3 & 5,237 & & & & & & & & $\mathrm{H}$ & I & $\mathrm{J}$ & $\mathrm{K}$ & $\mathrm{L}$ & M & $\mathrm{N}$ & $\mathrm{O}$ & P & & & & & & & & \\
\hline DG112 & 2 & 5.200 & & & & & & & & $\mathrm{H}$ & I & $\mathrm{J}$ & $\mathrm{K}$ & $\mathrm{L}$ & $\mathrm{M}$ & $\mathrm{N}$ & $\mathrm{O}$ & P & & & & & & & & \\
\hline DG130 & 3 & 5,093 & & & & & & & & $\mathrm{H}$ & I & $\mathrm{J}$ & $\mathrm{K}$ & $\mathrm{L}$ & M & $\mathrm{N}$ & $\mathrm{O}$ & P & & & & & & & & \\
\hline DG69 & 1 & 5,087 & & & & & & & & $\mathrm{H}$ & I & $\mathrm{J}$ & $\mathrm{K}$ & $\mathrm{L}$ & $\mathrm{M}$ & $\mathrm{N}$ & $\mathrm{O}$ & P & & & & & & & & \\
\hline DG46 & 1 & 5,087 & & & & & & & & $\mathrm{H}$ & I & $\mathrm{J}$ & $\mathrm{K}$ & $\mathrm{L}$ & M & $\mathrm{N}$ & $\mathrm{O}$ & P & & & & & & & & \\
\hline DG59 & 1 & 5.053 & & & & & & & & & I & $\mathrm{J}$ & $\mathrm{K}$ & $\mathrm{L}$ & $\mathrm{M}$ & $\mathrm{N}$ & $\mathrm{O}$ & $\mathrm{P}$ & Q & & & & & & & \\
\hline DG133 & 3 & 5,053 & & & & & & & & & I & $\mathrm{J}$ & $\mathrm{K}$ & $\mathrm{L}$ & M & $\mathbf{N}$ & $\mathrm{O}$ & $\mathrm{P}$ & $\mathrm{Q}$ & & & & & & & \\
\hline DG73 & 1 & 5.010 & & & & & & & & & I & $\mathrm{J}$ & $\mathrm{K}$ & $\mathrm{L}$ & $\mathrm{M}$ & $\mathbf{N}$ & $\mathrm{O}$ & $P$ & Q & & & & & & & \\
\hline DG50 & 1 & 4,950 & & & & & & & & & I & $\mathrm{J}$ & $\mathrm{K}$ & $\mathrm{L}$ & M & $\mathrm{N}$ & $\mathrm{O}$ & $\mathrm{P}$ & $\mathrm{Q}$ & $\mathrm{R}$ & & & & & & \\
\hline DG126 & 3 & 4.857 & & & & & & & & & & $\mathrm{~J}$ & $\mathrm{~K}$ & $\mathrm{~L}$ & M & $\mathrm{N}$ & $\mathrm{O}$ & P & Q & $\mathrm{R}$ & $S$ & & & & & \\
\hline DG65 & 1 & 4,713 & & & & & & & & & & & $\mathrm{~K}$ & $\mathrm{~L}$ & M & $\mathrm{N}$ & $\mathrm{O}$ & $\mathrm{P}$ & Q & $\mathrm{R}$ & $S$ & $T$ & & & & \\
\hline DG129 & 3 & 4,680 & & & & & & & & & & & & $\mathrm{~L}$ & $\mathrm{M}$ & $\mathrm{N}$ & $\mathrm{O}$ & $\mathrm{P}$ & Q & $\mathrm{R}$ & S & $\mathrm{T}$ & & & & \\
\hline DG68 & 1 & 4,640 & & & & & & & & & & & & & M & $\mathrm{N}$ & $\mathrm{O}$ & $\mathrm{P}$ & $\mathrm{Q}$ & $\mathrm{R}$ & $S$ & $\mathrm{~T}$ & & & & \\
\hline MANT & IAC & 4.617 & & & & & & & & & & & & & M & $\mathrm{N}$ & $\mathrm{O}$ & P & Q & $\mathrm{R}$ & $\mathrm{S}$ & $\mathrm{T}$ & & & & \\
\hline DG47 & 1 & 4,467 & & & & & & & & & & & & & & $\mathrm{~N}$ & $\mathrm{O}$ & $\mathrm{P}$ & Q & $\mathrm{R}$ & $\mathrm{S}$ & $\mathrm{T}$ & $U$ & & & \\
\hline DG118 & 2 & 4,423 & & & & & & & & & & & & & & & $\mathrm{O}$ & $P$ & $\mathrm{Q}$ & $\mathrm{R}$ & $S$ & $T$ & $\mathrm{U}$ & & & \\
\hline DG132 & 3 & 4,410 & & & & & & & & & & & & & & & $\mathrm{O}$ & $\mathrm{P}$ & $\mathrm{Q}$ & $\mathrm{R}$ & $S$ & $\mathrm{~T}$ & $\mathrm{U}$ & & & \\
\hline DG58 & 1 & 4.287 & & & & & & & & & & & & & & & & P & Q & $\mathrm{R}$ & $S$ & $\mathrm{~T}$ & $\mathrm{U}$ & V & & \\
\hline DG116 & 2 & 4.023 & & & & & & & & & & & & & & & & & $\mathrm{Q}$ & $\mathrm{R}$ & $S$ & $\mathrm{~T}$ & $\mathrm{U}$ & V & & \\
\hline DG115 & 2 & 3,960 & & & & & & & & & & & & & & & & & & $\mathrm{R}$ & $S$ & $\mathrm{~T}$ & U & V & & \\
\hline DG125 & 2 & 3,957 & & & & & & & & & & & & & & & & & & $\mathrm{R}$ & $S$ & $\mathrm{~T}$ & $\mathrm{U}$ & V & & \\
\hline DG43 & 1 & 3,880 & & & & & & & & & & & & & & & & & & & $S$ & $\mathrm{~T}$ & $\mathrm{U}$ & V & W & \\
\hline DG44 & 1 & 3,867 & & & & & & & & & & & & & & & & & & & $S$ & $\mathrm{~T}$ & $\mathrm{U}$ & V & $w$ & \\
\hline DG56 & 1 & 3,770 & & & & & & & & & & & & & & & & & & & & $\mathrm{~T}$ & $\mathrm{U}$ & V & W & $\mathrm{x}$ \\
\hline DG138 & 2 & 3,757 & & & & & & & & & & & & & & & & & & & & $\mathrm{~T}$ & $\mathrm{U}$ & V & w & $x$ \\
\hline DG113 & 2 & 3.737 & & & & & & & & & & & & & & & & & & & & $\mathrm{~T}$ & $\mathrm{U}$ & V & w & $X$ \\
\hline DG114 & 2 & 3,563 & & & & & & & & & & & & & & & & & & & & & $\mathrm{U}$ & V & W & $\mathrm{X}$ \\
\hline DG51 & 1 & 3,490 & & & & & & & & & & & & & & & & & & & & & $\mathrm{U}$ & V & W & $x$ \\
\hline DG60 & 1 & 3,307 & & & & & & & & & & & & & & & & & & & & & & V & W & $\mathrm{X}$ \\
\hline DG123 & 2 & 3.253 & & & & & & & & & & & & & & & & & & & & & & V & W & $x$ \\
\hline DG45 & 1 & 2.883 & & & & & & & & & & & & & & & & & & & & & & & W & $\mathrm{X}$ \\
\hline DG111 & 2 & 2,793 & & & & & & & & & & & & & & & & & & & & & & & & $X$ \\
\hline
\end{tabular}


Tabela 20. Teste de Tukey a 5\% de Probabilidade, variável 30 porcentagem de proteína no caule. na base seca, $\Delta_{5 \%}=0,936$.

\begin{tabular}{|c|c|c|c|c|c|c|c|c|c|c|c|c|c|c|c|c|c|c|c|c|c|c|c|c|c|c|c|c|c|c|c|}
\hline Etv & $\operatorname{Re}$ & Med & $A$ & B & $\mathrm{C}$ & $\mathrm{D}$ & E & $\mathrm{F}$ & G & $\mathrm{H}$ & I & $\mathrm{J}$ & $\mathrm{K}$ & $\mathrm{L}$ & $\mathbf{M}$ & $\mathrm{N}$ & $\mathrm{O}$ & $P$ & $\mathrm{Q}$ & $\mathrm{R}$ & $S$ & $\mathrm{~T}$ & $\mathrm{U}$ & V & $w$ & $\mathrm{X}$ & $\mathrm{Y}$ & 2 & $\mathrm{~A}$ & B & C \\
\hline DG122 & 2 & 8.760 & A & & & & & & & & & & & & & & & & & & & & & & & & & & & & \\
\hline DG61 & 1 & 7.723 & & B & & & & & & & & & & & & & & & & & & & & & & & & & & & \\
\hline DG71 & 1 & 7.273 & & B & $\mathrm{C}$ & & & & & & & & & & & & & & & & & & & & & & & & & & \\
\hline DG131 & 3 & 7.183 & & B & $\mathrm{C}$ & D & & & & & & & & & & & & & & & & & & & & & & & & & \\
\hline DG133 & 3 & 7.180 & & B & $\mathrm{C}$ & $\mathrm{D}$ & & & & & & & & & & & & & & & & & & & & & & & & & \\
\hline DG124 & 2 & 7.107 & & B & C & D & $E$ & & & & & & & & & & & & & & & & & & & & & & & & \\
\hline DG129 & 3 & 6.787 & & & $\mathrm{C}$ & D & $\mathrm{E}$ & $\mathrm{F}$ & & & & & & & & & & & & & & & & & & & & & & & \\
\hline DG134 & 3 & 6.650 & & & $\mathrm{C}$ & D & $E$ & $\mathrm{~F}$ & G & & & & & & & & & & & & & & & & & & & & & & \\
\hline DG125 & 2 & 6.587 & & & C & D & $\mathrm{E}$ & $\mathrm{F}$ & G & & & & & & & & & & & & & & & & & & & & & & \\
\hline DG38 & 1 & 6.557 & & & $\mathrm{C}$ & D & $\mathrm{E}$ & $\mathrm{F}$ & G & & & & & & & & & & & & & & & & & & & & & & \\
\hline DG48 & 1 & 6.400 & & & $\mathrm{C}$ & $\mathrm{D}$ & $\mathrm{E}$ & $\mathrm{F}$ & G & $\mathrm{H}$ & & & & & & & & & & & & & & & & & & & & & \\
\hline DG115 & 2 & 6.263 & & & & D & $E$ & $\mathrm{~F}$ & G & $\mathrm{H}$ & I & & & & & & & & & & & & & & & & & & & & \\
\hline DG130 & 3 & 6.253 & & & & $\mathrm{D}$ & $E$ & $\mathrm{~F}$ & G & $\mathrm{H}$ & I & & & & & & & & & & & & & & & & & & & & \\
\hline DG116 & 2 & 6.197 & & & & & $\mathrm{E}$ & $\mathrm{F}$ & G & $\mathrm{H}$ & I & $\mathrm{J}$ & & & & & & & & & & & & & & & & & & & \\
\hline DG127 & 3 & 6.043 & & & & & & $\mathrm{~F}$ & G & $\mathrm{H}$ & I & $\mathbf{J}$ & $\mathrm{K}$ & & & & & & & & & & & & & & & & & & \\
\hline DG128 & 3 & 5.993 & & & & & & $\mathrm{~F}$ & G & $\mathrm{H}$ & I & $J$ & $\mathrm{~K}$ & $\mathrm{~L}$ & & & & & & & & & & & & & & & & & \\
\hline DG67 & 1 & 5.830 & & & & & & & G & $\mathrm{H}$ & I & $\mathrm{J}$ & $\mathrm{K}$ & $\mathrm{L}$ & M & & & & & & & & & & & & & & & & \\
\hline DG121 & 2 & 5.813 & & & & & & & G & $\mathrm{H}$ & I & $\mathrm{J}$ & $\mathrm{K}$ & $\mathrm{L}$ & M & & & & & & & & & & & & & & & & \\
\hline DG47 & 1 & 5.720 & & & & & & & G & $\mathrm{H}$ & I & $\mathrm{J}$ & $\mathrm{K}$ & $\mathrm{L}$ & M & & & & & & & & & & & & & & & & \\
\hline DG65 & 1 & 5.603 & & & & & & & & $\mathrm{H}$ & I & $J$ & $\mathrm{~K}$ & $\mathrm{~L}$ & $\mathrm{M}$ & $\mathrm{N}$ & & & & & & & & & & & & & & & \\
\hline DG52 & 1 & 5.510 & & & & & & & & $\mathrm{H}$ & I & $\mathrm{J}$ & $\mathrm{K}$ & $\mathrm{L}$ & $\mathrm{M}$ & $\mathrm{N}$ & $\mathrm{O}$ & & & & & & & & & & & & & & \\
\hline DG41 & 1 & 5.497 & & & & & & & & $\mathrm{H}$ & I & $\mathrm{J}$ & $\mathrm{K}$ & $\mathrm{L}$ & $\mathbf{M}$ & $\mathrm{N}$ & $\mathrm{O}$ & & & & & & & & & & & & & & \\
\hline DG117 & 2 & 5.400 & & & & & & & & & I & $\mathrm{J}$ & $\mathrm{K}$ & $\mathrm{L}$ & $\mathrm{M}$ & $\mathrm{N}$ & $\mathrm{O}$ & $\mathrm{P}$ & & & & & & & & & & & & & \\
\hline DG62 & 1 & 5.380 & & & & & & & & & I & $\mathrm{J}$ & $\mathrm{K}$ & $\mathrm{L}$ & $\mathrm{M}$ & $\mathrm{N}$ & $\mathrm{O}$ & $\mathrm{P}$ & $\mathrm{Q}$ & & & & & & & & & & & & \\
\hline DG39 & 1 & 5.370 & & & & & & & & & I & $\mathrm{J}$ & $\mathrm{K}$ & $\mathrm{L}$ & $M$ & $\mathrm{~N}$ & $\mathrm{O}$ & $\mathrm{P}$ & Q & & & & & & & & & & & & \\
\hline DG46 & 1 & 5.280 & & & & & & & & & & $\mathrm{~J}$ & $\mathrm{~K}$ & $\mathrm{~L}$ & $\mathbf{M}$ & $\mathrm{N}$ & $\mathrm{O}$ & $\mathrm{P}$ & $\mathrm{Q}$ & $\mathrm{R}$ & & & & & & & & & & & \\
\hline DG69 & 1 & 5.233 & & & & & & & & & & & $\mathrm{~K}$ & $\mathrm{~L}$ & $\mathrm{M}$ & $\mathrm{N}$ & $\mathrm{O}$ & $\mathrm{P}$ & $\mathrm{Q}$ & $\mathrm{R}$ & & & & & & & & & & & \\
\hline DG73 & 1 & 5.203 & & & & & & & & & & & $\mathrm{~K}$ & $\mathrm{~L}$ & $\mathbf{M}$ & $\mathrm{N}$ & $\mathrm{O}$ & $P$ & $\mathrm{Q}$ & $\mathrm{R}$ & & & & & & & & & & & \\
\hline DG42 & 1 & 5.127 & & & & & & & & & & & $\mathrm{~K}$ & $\mathrm{~L}$ & $\mathrm{M}$ & $\mathrm{N}$ & $\mathrm{O}$ & $\mathrm{P}$ & $\mathrm{Q}$ & $\mathrm{R}$ & $S$ & & & & & & & & & & \\
\hline DG55 & 1 & 5.093 & & & & & & & & & & & & $\mathrm{~L}$ & $\mathrm{M}$ & $\mathrm{N}$ & $\mathrm{O}$ & $\mathrm{P}$ & $\mathrm{Q}$ & $\mathrm{R}$ & $\mathrm{S}$ & & & & & & & & & & \\
\hline DG112 & 2 & 4.933 & & & & & & & & & & & & & $\mathrm{M}$ & $\mathrm{N}$ & $\mathrm{O}$ & $P$ & $\mathrm{Q}$ & $\mathrm{R}$ & $S$ & $\mathrm{~T}$ & & & & & & & & & \\
\hline DG58 & 1 & 4.780 & & & & & & & & & & & & & & $\mathrm{~N}$ & $\mathrm{O}$ & $\mathrm{P}$ & $\mathrm{Q}$ & $\mathrm{R}$ & $S$ & $\mathrm{~T}$ & U & & & & & & & & \\
\hline DG43 & 1 & 4.670 & & & & & & & & & & & & & & $\mathrm{~N}$ & $\mathrm{O}$ & $\mathrm{P}$ & $\mathrm{Q}$ & $\mathrm{R}$ & $\mathrm{S}$ & $\mathrm{T}$ & $\mathrm{U}$ & V & & & & & & & \\
\hline DG70 & 1 & 4.613 & & & & & & & & & & & & & & & $\mathrm{O}$ & $P$ & $\mathrm{Q}$ & $\mathrm{R}$ & $\mathrm{S}$ & $\mathrm{T}$ & $\mathrm{U}$ & V & w & & & & & & \\
\hline DG132 & 3 & 4.547 & & & & & & & & & & & & & & & & $P$ & Q & $\mathrm{R}$ & $\mathrm{S}$ & $\mathrm{T}$ & $\mathrm{U}$ & v & W & $\mathrm{x}$ & & & & & \\
\hline DG49 & 1 & 4.520 & & & & & & & & & & & & & & & & $P$ & $\mathrm{Q}$ & $\mathrm{R}$ & $\mathrm{S}$ & $\mathrm{T}$ & $\mathrm{U}$ & V & W & $\mathrm{X}$ & & & & & \\
\hline DG114 & 2 & 4.453 & & & & & & & & & & & & & & & & & $\mathrm{Q}$ & $\mathrm{R}$ & $\mathrm{S}$ & $\mathrm{T}$ & $\mathrm{U}$ & V & W & $\mathrm{X}$ & $Y$ & & & & \\
\hline DG68 & 1 & 4.367 & & & & & & & & & & & & & & & & & & $\mathrm{R}$ & $S$ & $\mathrm{~T}$ & $\mathrm{U}$ & V & $w$ & $\mathrm{X}$ & $Y$ & $Z$ & & & \\
\hline DG40 & 1 & 4.197 & & & & & & & & & & & & & & & & & & & $S$ & $\mathrm{~T}$ & $\mathrm{U}$ & v & W & $\mathrm{X}$ & $\mathrm{Y}$ & $Z$ & A & & \\
\hline DG120 & 2 & 4.123 & & & & & & & & & & & & & & & & & & & & $\mathrm{~T}$ & $U$ & v & w & $\mathrm{X}$ & $\mathrm{Y}$ & $Z$ & A & & \\
\hline DG54 & 1 & 3.970 & & & & & & & & & & & & & & & & & & & & & $\mathrm{U}$ & V & w & $\mathrm{X}$ & $\mathrm{Y}$ & $Z$ & A & & \\
\hline DG59 & 1 & 3.880 & & & & & & & & & & & & & & & & & & & & & $\mathrm{U}$ & V & W & $x$ & $\mathrm{Y}$ & $Z$ & A & & \\
\hline DG45 & 1 & 3.833 & & & & & & & & & & & & & & & & & & & & & & v & W & $\mathrm{X}$ & Y & Z & $A$ & & \\
\hline DG44 & 1 & 3.800 & & & & & & & & & & & & & & & & & & & & & & V & W & $\mathrm{X}$ & Y & 2 & A & & \\
\hline DG123 & 2 & 3.680 & & & & & & & & & & & & & & & & & & & & & & & W & $x$ & Y & $Z$ & $A$ & & \\
\hline DG113 & 2 & 3.667 & & & & & & & & & & & & & & & & & & & & & & & & $\mathrm{X}$ & $\mathrm{Y}$ & $Z$ & A & & \\
\hline DG126 & 3 & 3.633 & & & & & & & & & & & & & & & & & & & & & & & & $\mathrm{X}$ & $\mathrm{Y}$ & $Z$ & A & & \\
\hline DG56 & 1 & 3.620 & & & & & & & & & & & & & & & & & & & & & & & & $\mathrm{X}$ & $\mathrm{Y}$ & $Z$ & A & & \\
\hline DG60 & 1 & 3.580 & & & & & & & & & & & & & & & & & & & & & & & & & Y & $Z$ & A & & \\
\hline DG50 & 1 & 3.457 & & & & & & & & & & & & & & & & & & & & & & & & & & $Z$ & $\mathrm{~A}$ & B & \\
\hline DG119 & 2 & 3.453 & & & & & & & & & & & & & & & & & & & & & & & & & & $Z$ & A & B & \\
\hline DG51 & 1 & 3.360 & & & & & & & & & & & & & & & & & & & & & & & & & & & A & B & \\
\hline MANT & IA & 3.293 & & & & & & & & & & & & & & & & & & & & & & & & & & & $\mathrm{~A}$ & B & \\
\hline DG138 & 2 & 2.567 & & & & & & & & & & & & & & & & & & & & & & & & & & & & B & C \\
\hline DG118 & 2 & 1.937 & & & & & & & & & & & & & & & & & & & & & & & & & & & & & C \\
\hline DGI11 & 2 & 1.863 & & & & & & & & & & & & & & & & & & & & & & & & & & & & & C \\
\hline
\end{tabular}

Região 1: Rio Negro - Bacia Amazònica Região 2: Rio Solimões - Bacia Amazônica Região 3: Litoral 5ul - SP 
Tabela 21 . Teste de Tukey a $5 \%$ de probabilidade, variável 31 porcentagem de fibra no caule, na base seca. $\Delta_{5 \%}=2,237$.

\begin{tabular}{|c|c|c|c|c|c|c|c|c|c|c|c|c|c|c|c|c|c|c|c|c|c|c|c|c|c|c|}
\hline Etnov. & Reg & Med & $\mathrm{A}$ & B & $\mathrm{C}$ & $\mathrm{D}$ & $\mathrm{E}$ & $\mathrm{F}$ & $\mathrm{G}$ & $\mathrm{H}$ & I & $\mathrm{J}$ & $\mathrm{K}$ & $\mathrm{L}$ & $M$ & $\mathrm{~N}$ & $\mathrm{O}$ & $P$ & $\mathrm{Q}$ & 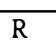 & $S$ & $\mathrm{~T}$ & $\mathrm{U}$ & $\mathrm{V}$ & $W$ & $\mathrm{X}$ \\
\hline DG111 & 2 & 62,880 & A & & & & & & & & & & & & & & & & & & & & & & & \\
\hline DG60 & 1 & 60,620 & & B & & & & & & & & & & & & & & & & & & & & & & \\
\hline DG138 & 2 & 58,853 & & B & C & & & & & & & & & & & & & & & & & & & & & \\
\hline DG50 & 1 & 57,927 & & & C & D & & & & & & & & & & & & & & & & & & & & \\
\hline DG51 & 1 & 57,920 & & & $\mathrm{C}$ & D & & & & & & & & & & & & & & & & & & & & \\
\hline DG118 & 2 & 57,237 & & & C & D & E & & & & & & & & & & & & & & & & & & & \\
\hline DG47 & 1 & 57,210 & & & $\mathrm{C}$ & D & E & & & & & & & & & & & & & & & & & & & \\
\hline DG54 & 1 & 57,170 & & & C & $\mathrm{D}$ & E & & & & & & & & & & & & & & & & & & & \\
\hline DG44 & 1 & 56,740 & & & C & D & E & $\mathrm{F}$ & & & & & & & & & & & & & & & & & & \\
\hline DG40 & 1 & 56.473 & & & & D & E & $\mathrm{F}$ & & & & & & & & & & & & & & & & & & \\
\hline DG123 & 2 & 56,030 & & & & D & E & $\mathrm{F}$ & G & & & & & & & & & & & & & & & & & \\
\hline DG59 & 1 & 55,980 & & & & D & E & $\mathrm{F}$ & G & & & & & & & & & & & & & & & & & \\
\hline DG71 & 1 & 55,940 & & & & D & $\mathrm{E}$ & $\mathrm{F}$ & $\mathrm{G}$ & & & & & & & & & & & & & & & & & \\
\hline DG134 & 3 & 55,860 & & & & D & $\mathrm{E}$ & $\mathrm{F}$ & $\mathrm{G}$ & $\mathrm{H}$ & & & & & & & & & & & & & & & & \\
\hline DG122 & 2 & 55,467 & & & & & $\mathrm{E}$ & $\mathrm{F}$ & $\mathrm{G}$ & $\mathrm{H}$ & I & & & & & & & & & & & & & & & \\
\hline DG52 & 1 & 55,420 & & & & & E & $\mathrm{F}$ & $\mathrm{G}$ & $\mathrm{H}$ & I & & & & & & & & & & & & & & & \\
\hline DG125 & 2 & 54,750 & & & & & & $\mathrm{~F}$ & $\mathrm{G}$ & $\mathrm{H}$ & I & $\mathrm{J}$ & & & & & & & & & & & & & & \\
\hline DG112 & 2 & 54,717 & & & & & & $\mathrm{~F}$ & $\mathrm{G}$ & $\mathrm{H}$ & I & $\mathrm{J}$ & $\mathrm{K}$ & & & & & & & & & & & & & \\
\hline DG43 & 1 & 54,657 & & & & & & $\mathrm{~F}$ & G & $\mathrm{H}$ & I & $J$ & $\mathrm{~K}$ & & & & & & & & & & & & & \\
\hline DG113 & 2 & 54,540 & & & & & & $\mathrm{~F}$ & G & $\mathrm{H}$ & I & $J$ & $\mathrm{~K}$ & $\mathrm{~L}$ & & & & & & & & & & & & \\
\hline DG115 & 2 & 54,123 & & & & & & & G & $\mathrm{H}$ & I & $\mathrm{J}$ & $\mathrm{K}$ & $\mathrm{L}$ & M & & & & & & & & & & & \\
\hline DG56 & 1 & 54,090 & & & & & & & $\mathrm{G}$ & $\mathrm{H}$ & I & $\mathrm{J}$ & $\mathrm{K}$ & $\mathrm{L}$ & $M$ & $\mathrm{~N}$ & & & & & & & & & & \\
\hline DG62 & 1 & 54,073 & & & & & & & $\mathrm{G}$ & $\mathrm{H}$ & I & $\mathrm{J}$ & $\mathrm{K}$ & $\mathrm{L}$ & $M$ & $\mathrm{~N}$ & & & & & & & & & & \\
\hline DG126 & 3 & 54,067 & & & & & & & $\mathrm{G}$ & $\mathrm{H}$ & I & $\mathrm{J}$ & $\mathrm{K}$ & $\mathrm{L}$ & $\mathrm{M}$ & $\mathrm{N}$ & & & & & & & & & & \\
\hline MANT & IAC & 54.053 & & & & & & & G & $\mathrm{H}$ & I & $\mathrm{J}$ & $\mathrm{K}$ & $\mathrm{L}$ & $\mathrm{M}$ & $\mathrm{N}$ & & & & & & & & & & \\
\hline DG73 & 1 & 53,677 & & & & & & & & $\mathrm{H}$ & I & $\mathrm{J}$ & $\mathrm{K}$ & $\mathrm{L}$ & $\mathrm{M}$ & $\mathrm{N}$ & $\mathrm{O}$ & & & & & & & & & \\
\hline DG58 & 1 & 53,477 & & & & & & & & & I & $\mathrm{J}$ & $\mathrm{K}$ & $\mathrm{L}$ & $\mathrm{M}$ & $\mathrm{N}$ & $\mathrm{O}$ & & & & & & & & & \\
\hline DG 128 & 3 & 53,463 & & & & & & & & & I & $\mathrm{J}$ & $\mathrm{k}$ & $\mathrm{L}$ & $\mathrm{M}$ & $\mathrm{N}$ & $\mathrm{O}$ & & & & & & & & & \\
\hline DG132 & 3 & 53,327 & & & & & & & & & I & $\mathrm{J}$ & $\mathrm{K}$ & $\mathrm{L}$ & $\mathrm{M}$ & $\mathrm{N}$ & $\mathrm{O}$ & $P$ & & & & & & & & \\
\hline DG130 & 3 & 53.087 & & & & & & & & & & $\mathrm{~J}$ & $\mathrm{~K}$ & $\mathrm{~L}$ & $\mathrm{M}$ & $\mathrm{N}$ & $\mathrm{O}$ & P & & & & & & & & \\
\hline DG124 & 2 & 52,927 & & & & & & & & & & $\mathrm{~J}$ & $\mathrm{~K}$ & $\mathrm{~L}$ & $\mathrm{M}$ & $\mathrm{N}$ & $\mathrm{O}$ & $\mathrm{P}$ & Q & & & & & & & \\
\hline DG67 & 1 & 52,830 & & & & & & & & & & $\mathrm{~J}$ & $\mathrm{~K}$ & $\mathrm{~L}$ & $\mathrm{M}$ & $\mathrm{N}$ & $\mathrm{O}$ & $P$ & $Q$ & $\mathrm{R}$ & & & & & & \\
\hline DG42 & 1 & 52,690 & & & & & & & & & & $\mathrm{~J}$ & $\mathrm{~K}$ & $\mathrm{~L}$ & $\mathrm{M}$ & $\mathrm{N}$ & $\mathrm{O}$ & $\mathrm{P}$ & $\mathrm{Q}$ & $\mathrm{R}$ & & & & & & \\
\hline DG119 & 2 & 52,663 & & & & & & & & & & $\mathrm{~J}$ & $\mathrm{~K}$ & $\mathrm{~L}$ & $\mathrm{M}$ & $\mathrm{N}$ & $\mathrm{O}$ & $P$ & $Q$ & $\mathrm{R}$ & & & & & & \\
\hline DG129 & 3 & 52,487 & & & & & & & & & & & $\mathrm{~K}$ & $\mathrm{~L}$ & $\mathrm{M}$ & $\mathrm{N}$ & $\mathrm{O}$ & $P$ & $\mathrm{Q}$ & $\mathrm{R}$ & & & & & & \\
\hline DG69 & 1 & 52,390 & & & & & & & & & & & & $\mathrm{~L}$ & $\mathrm{M}$ & $\mathrm{N}$ & $\mathrm{O}$ & $\mathrm{P}$ & Q & $\mathrm{R}$ & $S$ & & & & & \\
\hline DG116 & 2 & 52,287 & & & & & & & & & & & & & $\mathrm{M}$ & $\mathrm{N}$ & $\mathrm{O}$ & P & $\mathrm{Q}$ & $\mathrm{R}$ & $S$ & & & & & \\
\hline DG46 & 1 & 52,273 & & & & & & & & & & & & & $\mathrm{M}$ & $\mathrm{N}$ & $\mathrm{O}$ & $\mathrm{P}$ & $Q$ & $\mathrm{R}$ & $\mathrm{S}$ & & & & & \\
\hline DG120 & 2 & 52,267 & & & & & & & & & & & & & $\mathrm{M}$ & $N$ & $\mathrm{O}$ & $P$ & $\mathrm{Q}$ & $\mathrm{R}$ & $S$ & & & & & \\
\hline DG127 & 3 & 51,887 & & & & & & & & & & & & & $\mathrm{M}$ & $\mathrm{N}$ & $\mathrm{O}$ & $\mathrm{P}$ & Q & $\mathrm{R}$ & $\mathrm{S}$ & $\mathrm{T}$ & & & & \\
\hline DG70 & 1 & 51,873 & & & & & & & & & & & & & & $\mathrm{~N}$ & $\mathrm{O}$ & P & Q & $\mathrm{R}$ & $\mathrm{S}$ & $\mathrm{T}$ & & & & \\
\hline DG55 & 1 & 51,707 & & & & & & & & & & & & & & & $\mathrm{O}$ & $P$ & $\mathrm{Q}$ & $\mathrm{R}$ & $S$ & $\mathrm{~T}$ & & & & \\
\hline DG114 & 2 & 51,467 & & & & & & & & & & & & & & & $\mathrm{O}$ & $P$ & $\mathrm{Q}$ & $\mathrm{R}$ & $S$ & $\mathrm{~T}$ & $\mathrm{U}$ & & & \\
\hline DG121 & 2 & 51,113 & & & & & & & & & & & & & & & & $\mathrm{P}$ & Q & $\mathrm{R}$ & $S$ & $\mathrm{~T}$ & $\mathrm{U}$ & & & \\
\hline DG39 & 1 & 50.817 & & & & & & & & & & & & & & & & & Q & $\mathrm{R}$ & $S$ & $\mathrm{~T}$ & $\mathrm{U}$ & & & \\
\hline DG48 & 1 & 50,707 & & & & & & & & & & & & & & & & & $Q$ & $\mathrm{R}$ & $S$ & $\mathrm{~T}$ & $\mathrm{U}$ & & & \\
\hline DG68 & 1 & 50,683 & & & & & & & & & & & & & & & & & & $\mathrm{R}$ & $S$ & $\mathrm{~T}$ & $\mathrm{U}$ & & & \\
\hline DG41 & $i$ & 50,217 & & & & & & & & & & & & & & & & & & & $S$ & $\mathrm{~T}$ & $\mathrm{U}$ & & & \\
\hline DG49 & 1 & 50,167 & & & & & & & & & & & & & & & & & & & $\mathrm{~S}$ & $\mathrm{~T}$ & $\mathrm{U}$ & & & \\
\hline DG131 & 3 & 49,820 & & & & & & & & & & & & & & & & & & & & $\mathrm{~T}$ & $\mathrm{U}$ & V & & \\
\hline DG117 & 2 & 49,397 & & & & & & & & & & & & & & & & & & & & & $\mathrm{U}$ & V & & \\
\hline DG65 & 1 & 47,687 & & & & & & & & & & & & & & & & & & & & & & V & W & \\
\hline DG133 & 3 & 47,013 & & & & & & & & & & & & & & & & & & & & & & & w & \\
\hline DG61 & 1 & 46,060 & & & & & & & & & & & & & & & & & & & & & & & W & \\
\hline DG38 & 1 & 45,573 & & & & & & & & & & & & & & & & & & & & & & & W & $\mathrm{x}$ \\
\hline DG45 & 1 & 43,730 & & & & & & & & & & & & & & & & & & & & & & & & $x$ \\
\hline
\end{tabular}


Tabela 22. Teste de Tukey a $5 \%$ de probabilidade, variável 32 porcentagem de matéria graxa no caule, na base seca, $\Delta_{5 \%}=0,612$.

\begin{tabular}{|c|c|c|c|c|c|c|c|c|c|c|c|c|c|c|c|}
\hline Etnov. & Região & Média & $\mathrm{A}$ & B & $\mathrm{C}$ & D & $E$ & $F$ & $G$ & $\mathrm{H}$ & I & $J$ & $\mathrm{~K}$ & $\mathrm{~L}$ & $\mathrm{M}$ \\
\hline DG121 & 2 & 1,970 & A & & & & & & & & & & & & \\
\hline DG65 & 1 & 1,923 & A & B & & & & & & & & & & & \\
\hline DG130 & 3 & 1.893 & A & B & C & & & & & & & & & & \\
\hline DG38 & 1 & 1,890 & A & B & C & & & & & & & & & & \\
\hline DG114 & 2 & 1,853 & A & B & $\mathrm{C}$ & & & & & & & & & & \\
\hline DG71 & 1 & 1.830 & A & B & $\mathrm{C}$ & D & & & & & & & & & \\
\hline DG113 & 2 & 1,827 & A & B & C & D & & & & & & & & & \\
\hline DG117 & 2 & 1.817 & A & B & C & D & & & & & & & & & \\
\hline MANT & IAC & 1.813 & A & B & C & D & & & & & & & & & \\
\hline DG56 & 1 & 1.797 & A & B & C & D & $\mathrm{E}$ & & & & & & & & \\
\hline DG46 & 1 & 1.797 & A & B & C & D & $E$ & & & & & & & & \\
\hline DG68 & 1 & 1.793 & A & B & $\mathrm{C}$ & D & $\mathrm{E}$ & & & & & & & & \\
\hline DG61 & 1 & 1.790 & $A$ & B & C & D & $\mathrm{E}$ & & & & & & & & \\
\hline DG131 & 3 & 1.777 & A & B & C & D & E & & & & & & & & \\
\hline DG69 & 1 & 1.750 & A & B & C & D & $E$ & $\mathrm{~F}$ & & & & & & & \\
\hline DG59 & 1 & 1.747 & A & B & $\mathrm{C}$ & D & $\mathrm{E}$ & $\mathrm{F}$ & & & & & & & \\
\hline DG124 & 2 & 1.707 & A & B & $\mathrm{C}$ & D & $\mathrm{E}$ & $\mathrm{F}$ & G & & & & & & \\
\hline DG39 & 1 & 1.703 & A & B & C & D & E & $\mathrm{F}$ & G & & & & & & \\
\hline DG47 & 1 & 1,700 & A & B & C & D & $E$ & $\mathrm{~F}$ & G & $\mathrm{H}$ & & & & & \\
\hline DG58 & 1 & 1,693 & A & B & C & D & $E$ & $\mathrm{~F}$ & G & $\mathrm{H}$ & & & & & \\
\hline DG133 & 3 & 1,690 & A & B & C & D & E & $\mathrm{F}$ & G & $\mathrm{H}$ & & & & & \\
\hline DG67 & 1 & 1.687 & A & B & C & D & E & $\mathrm{F}$ & G & $\mathrm{H}$ & & & & & \\
\hline DG129 & 3 & 1,667 & A & B & C & D & E & $\mathrm{F}$ & G & $\mathrm{H}$ & & & & & \\
\hline DG70 & 1 & 1,653 & A & B & C & D & $E$ & $\mathrm{~F}$ & G & $\mathrm{H}$ & I & & & & \\
\hline DG128 & 3 & 1.647 & A & B & C & D & E & $\mathrm{F}$ & G & $\mathrm{H}$ & I & & & & \\
\hline DG52 & 1 & 1.607 & A & B & $\mathrm{C}$ & D & E & $\mathrm{F}$ & $\mathrm{G}$ & $\mathrm{H}$ & I & $J$ & & & \\
\hline DG42 & 1 & 1,583 & A & B & $\mathrm{C}$ & D & $E$ & $\mathrm{~F}$ & G & $\mathrm{H}$ & 1 & $\mathrm{~J}$ & & & \\
\hline DG123 & 2 & 1.547 & A & B & C. & D & E & $\mathrm{F}$ & G & $\mathrm{H}$ & 1 & $\mathrm{~J}$ & $\mathrm{~K}$ & & \\
\hline DG43 & 1 & 1,540 & A & B & C & D & E & $\mathrm{F}$ & G & $\mathrm{H}$ & I & $\mathrm{J}$ & $\mathrm{K}$ & & \\
\hline DG127 & 3 & 1.517 & A & B & C & D & E & $\mathrm{F}$ & G & $\mathrm{H}$ & I & $\mathrm{J}$ & $\mathrm{K}$ & & \\
\hline DG41 & 1 & 1,490 & A & B & C & D & $E$ & $\mathrm{~F}$ & G & $\mathrm{H}$ & 1 & $\mathrm{~J}$ & $\mathrm{~K}$ & & \\
\hline DG5S & 1 & 1.470 & A & B & C & D & E & $\mathrm{F}$ & G & $\mathrm{H}$ & I & $\mathrm{J}$ & $\mathrm{K}$ & & \\
\hline DG132 & 3 & 1,447 & A & B & C & D & $\mathrm{E}$ & $\mathrm{F}$ & G & $\mathrm{H}$ & I & $\mathrm{J}$ & $\mathrm{K}$ & & \\
\hline DG134 & 3 & 1.443 & A & B & C & D & $\mathrm{E}$ & $\mathrm{F}$ & G & $\mathrm{H}$ & I & $\mathrm{J}$ & $\mathrm{K}$ & & \\
\hline DG62 & 1 & 1,420 & A & B & $\mathrm{C}$ & D & $\mathrm{E}$ & $\mathrm{F}$ & $\mathrm{G}$ & $\mathrm{H}$ & 1 & $\mathrm{~J}$ & $\mathrm{~K}$ & & \\
\hline DG116 & 2 & 1,420 & A & B & $\mathrm{C}$ & D & E & $\mathrm{F}$ & G & $\mathrm{H}$ & I & $\mathrm{J}$ & $\mathrm{K}$ & & \\
\hline DG125 & 2 & 1.407 & A & B & $\mathrm{C}$ & D & $\mathrm{E}$ & $\mathrm{F}$ & $\mathrm{G}$ & $\mathrm{H}$ & I & $\mathrm{J}$ & $\mathrm{K}$ & & \\
\hline DG40 & 1 & 1,400 & A & B & $\mathrm{C}$ & D & $E$ & $\mathrm{~F}$ & G & $\mathrm{H}$ & I & $\mathrm{J}$ & $\mathrm{K}$ & & \\
\hline DG120 & 2 & 1.370 & A & B & C & D & $\mathrm{E}$ & $\mathrm{F}$ & G & $\mathrm{H}$ & I & $\mathrm{J}$ & $\mathrm{K}$ & $\mathrm{L}$ & \\
\hline DG119 & 2 & 1.367 & A & B & C & D & E & $\mathrm{F}$ & G & $\mathrm{H}$ & I & $\mathrm{J}$ & $\mathrm{K}$ & $\mathrm{L}$ & \\
\hline DG51 & 1 & 1.357 & & B & C & D & $E$ & $\mathrm{~F}$ & G & $\mathrm{H}$ & I & $\mathrm{J}$ & $\mathrm{K}$ & $\mathrm{L}$ & \\
\hline DG112 & 2 & 1.290 & & & C & D & $E$ & $\mathrm{~F}$ & G & $\mathrm{H}$ & 1 & $J$ & $\mathrm{~K}$ & L & \\
\hline DG115 & 2 & 1,283 & & & C & D & $\mathrm{E}$ & $\mathrm{F}$ & G & $\mathrm{H}$ & I & $\mathrm{J}$ & $\mathrm{K}$ & L & \\
\hline DG60 & 1 & 1.237 & & & & D & $\mathrm{E}$ & $\mathrm{F}$ & G & $\mathrm{H}$ & I & $\mathrm{J}$ & $\mathrm{K}$ & $\mathrm{L}$ & \\
\hline DG48 & 1 & 1,190 & & & & & E & $\mathrm{F}$ & G & $\mathrm{H}$ & I & $\mathrm{J}$ & $\mathrm{K}$ & $\mathrm{L}$ & M \\
\hline DG73 & 1 & 1.187 & & & & & E & $\mathrm{F}$ & G & $\mathrm{H}$ & I & $\mathrm{J}$ & $\mathrm{K}$ & $\mathrm{L}$ & $M$ \\
\hline DG126 & 3 & 1.153 & & & & & & $\mathrm{~F}$ & G & $\mathrm{H}$ & I & $\mathrm{J}$ & $\mathrm{K}$ & L & $M$ \\
\hline DG44 & 1 & 1,123 & & & & & & & G & $\mathrm{H}$ & 1 & $\mathrm{~J}$ & $\mathrm{~K}$ & $\mathrm{~L}$ & $\mathrm{M}$ \\
\hline DG138 & 2 & 1.120 & & & & & & & G & $\mathrm{H}$ & I & $\mathrm{J}$ & $\mathrm{K}$ & $\mathrm{L}$ & $\mathrm{M}$ \\
\hline DG49 & 1 & 1.090 & & & & & & & & $\mathrm{H}$ & I & $\mathrm{J}$ & $\mathrm{K}$ & L & $\mathrm{M}$ \\
\hline DGI118 & 2 & 1,053 & & & & & & & & & I & $\mathrm{J}$ & $\mathrm{K}$ & $\mathrm{L}$ & $\mathrm{M}$ \\
\hline DG122 & 2 & 1,030 & & & & & & & & & & $\mathrm{~J}$ & $\mathrm{~K}$ & $\mathrm{~L}$ & $M$ \\
\hline DG50 & 1 & 0.997 & & & & & & & & & & $\mathrm{~J}$ & $\mathrm{~K}$ & L & $M$ \\
\hline DG54 & 1 & 0.950 & & & & & & & & & & & $\mathrm{~K}$ & $\mathrm{~L}$ & $M$ \\
\hline DG45 & 1 & 0,770 & & & & & & & & & & & & L & $M$ \\
\hline DG111 & 2 & 0,607 & & & & & & & & & & & & & $M$ \\
\hline
\end{tabular}

Região 1: Rio Negro - Bacia Amazônica

Região 2: Rio Solimões - Bacia Amazonnica

Região 3: Litoral 5ul - SP 
Tabela 23 . Teste de Tukey a $5 \%$ de probabilidade, variável 33 porcentagem de carboidratos no caule, na base seca. $\Delta_{5 \%}=8,123$.

\begin{tabular}{|c|c|c|c|c|c|c|c|}
\hline Etnov. & Região & Média & $\mathrm{A}$ & $\mathrm{B}$ & $\mathrm{C}$ & $\mathrm{D}$ & $E$ \\
\hline DG134 & 3 & 37,873 & A & & & & \\
\hline DG65 & 1 & 37.140 & A & B & & & \\
\hline DG61 & 1 & 36,650 & A & B & & & \\
\hline DG133 & 3 & 35,760 & A & $\mathrm{B}$ & C & & \\
\hline DG68 & 1 & 35,537 & $A$ & B & $\mathrm{C}$ & D & \\
\hline DG117 & 2 & 35,520 & A & B & $\mathrm{C}$ & $\mathrm{D}$ & \\
\hline DG38 & 1 & 35,490 & A & B & $\mathrm{C}$ & $\mathrm{D}$ & \\
\hline DG114 & 2 & 35,270 & A & B & $\mathrm{C}$ & D & \\
\hline DG126 & 3 & 35.133 & A & B & C & D & \\
\hline DG49 & 1 & 34,760 & A & B & C & D & E \\
\hline DG119 & 2 & 34.223 & A & B & $\mathrm{C}$ & $\mathrm{D}$ & $\mathrm{E}$ \\
\hline DG70 & 1 & 33.733 & A & B & C & $\mathrm{D}$ & $\mathrm{E}$ \\
\hline DG56 & 1 & 33.723 & A & B & C & D & E \\
\hline MANT & IAC & 33.653 & A & B & C & D & E \\
\hline DG132 & 3 & 33.393 & A & B & C & D & E \\
\hline DG39 & 1 & 33.233 & A & B & C & D & E \\
\hline DG41 & 1 & 33,223 & $A$ & $\mathrm{~B}$ & $\mathrm{C}$ & $\mathrm{D}$ & E \\
\hline DG123 & 2 & 33.170 & A & B & $\mathrm{C}$ & $\mathrm{D}$ & E \\
\hline DG46 & 1 & 33,053 & A & B & $\mathrm{C}$ & $\mathrm{D}$ & E \\
\hline DG113 & 2 & 32,940 & A & B & C & D & E \\
\hline DG118 & 2 & 32,930 & A & B & $\mathrm{C}$ & D & $\mathrm{E}$ \\
\hline DG55 & 1 & 32,853 & A & B & $\mathrm{C}$ & D & E \\
\hline DG43 & 1 & 32.690 & A & B & $\mathrm{C}$ & $\mathrm{D}$ & $E$ \\
\hline DG127 & 3 & 32,667 & A & B & C & D & E \\
\hline DG69 & 1 & 32,640 & A & B & C & D & E \\
\hline DG42 & 1 & 32,557 & A & B & C & D & E \\
\hline DG116 & 2 & 32.553 & A & B & $\mathrm{C}$ & $\mathrm{D}$ & E \\
\hline DG121 & 2 & 32,500 & A & $\mathrm{B}$ & $\mathrm{C}$ & $\mathrm{D}$ & E \\
\hline DG131 & 3 & 32.353 & A & B & $\mathrm{C}$ & $\mathrm{D}$ & E \\
\hline DG58 & 1 & 32,333 & A & B & $\mathrm{C}$ & D & $\mathrm{E}$ \\
\hline DG120 & 2 & 32.253 & A & B & C & D & E \\
\hline DG48 & 1 & 32,120 & A & B & C & D & E \\
\hline DG73 & 1 & 32,070 & A & B & $\mathrm{C}$ & $\mathrm{D}$ & $\mathrm{E}$ \\
\hline DG115 & 2 & 31,940 & A & B & $\mathrm{C}$ & $\mathrm{D}$ & E \\
\hline DG44 & 1 & 31,933 & A & B & C & D & E \\
\hline DG67 & 1 & 31,827 & A & B & C & D & E \\
\hline DG138 & 2 & 31,820 & A & $\mathrm{B}$ & $\mathrm{C}$ & D & E \\
\hline DG129 & 3 & 31,687 & A & B & $\mathrm{C}$ & D & $\mathrm{E}$ \\
\hline DG112 & 2 & 31,513 & A & B & $\mathrm{C}$ & D & E \\
\hline DG125 & 2 & 31,480 & A & B & $\mathrm{C}$ & D & $E$ \\
\hline DG130 & 3 & 30,993 & A & B & $\mathrm{C}$ & D & E \\
\hline DG51 & 1 & 30.827 & A & B & C & D & $E$ \\
\hline DG59 & 1 & 30,510 & A & B & C & D & E \\
\hline DG128 & 3 & 30,143 & A & B & $\mathrm{C}$ & D & E \\
\hline DG62 & 1 & 30,137 & A & B & $\mathrm{C}$ & D & $\mathrm{E}$ \\
\hline DG40 & 1 & 30,040 & A & B & C & D & $E$ \\
\hline DG45 & 1 & 29,967 & A & B & C & D & E \\
\hline DG50 & 1 & 29,650 & & B & C & D & E \\
\hline DG124 & 2 & 29,587 & & B & C & D & E \\
\hline DG60 & 1 & 29.490 & & B & $\mathrm{C}$ & D & E \\
\hline DG111 & 2 & 29.247 & & B & $\mathrm{C}$ & D & $E$ \\
\hline DG52 & 1 & 29,183 & & B & C & D & $\mathrm{E}$ \\
\hline DG47 & 1 & 27,783 & & & C & D & E \\
\hline DG71 & 1 & 27,670 & & & C & D & E \\
\hline DG54 & 1 & 27.550 & & & & D & $E$ \\
\hline DG122 & 2 & 26.917 & & & & & $E$ \\
\hline
\end{tabular}


Tabela 24 . Teste de Tukey a 5\% de probabilidade, variável 34 potencial cianogênico na entrecasca da raiz, em $\mathrm{mg} / \mathrm{kg}$ na base seca, $\Delta_{5 \%}=55,633$.

\begin{tabular}{|c|c|c|c|c|c|c|c|c|c|c|c|c|c|c|c|c|c|c|}
\hline Etnov. & Reg & Uso & Módia & A & B & $\mathrm{C}$ & $\mathrm{D}$ & $E$ & F & G & $\mathrm{H}$ & I & $J$ & $\mathrm{~K}$ & $\mathrm{~L}$ & $M$ & $\mathrm{~N}$ & $\mathrm{O}$ \\
\hline DG43 & 1 & far. & 340,65 & A & & & & & & & & & & & & & & \\
\hline DG126 & 3 & far. & 317,05 & A & B & & & & & & & & & & & & & \\
\hline DG44 & 1 & far. & 294,84 & A & B & C & & & & & & & & & & & & \\
\hline DG73 & 1 & far. & 290.79 & A & $\mathrm{B}$ & $\mathrm{C}$ & & & & & & & & & & & & \\
\hline DG42 & 1 & far. & 282,43 & & B & $\mathrm{C}$ & & & & & & & & & & & & \\
\hline DG116 & 2 & far. & 282,35 & & B & $\mathrm{C}$ & & & & & & & & & & & & \\
\hline DG134 & 3 & mesa & 280,52 & & B & $\mathrm{C}$ & & & & & & & & & & & & \\
\hline DG114 & 2 & far. & 245.66 & & & $\mathrm{C}$ & D & & & & & & & & & & & \\
\hline DG121 & 2 & far. & 204,48 & & & & $\mathrm{D}$ & E & & & & & & & & & & \\
\hline DG115 & 2 & far. & 200.89 & & & & D & $\mathrm{E}$ & & & & & & & & & & \\
\hline DG117 & 2 & far. & 195,39 & & & & $\mathrm{D}$ & $\mathrm{E}$ & & & & & & & & & & \\
\hline DG133 & 3 & mesa & 184.75 & & & & & $\mathrm{E}$ & $\mathrm{F}$ & & & & & & & & & \\
\hline DG60 & 1 & far. & 181,24 & & & & & E & $\mathrm{F}$ & & & & & & & & & \\
\hline DG130 & 3 & mesa & 181.07 & & & & & E & F & & & & & & & & & \\
\hline DG120 & 2 & far. & 157,99 & & & & & E & $\mathrm{F}$ & G & & & & & & & & \\
\hline DG69 & 1 & far. & 148.98 & & & & & E & $\mathrm{F}$ & G & $\mathrm{H}$ & & & & & & & \\
\hline DG48 & 1 & far. & 136,22 & & & & & & $\mathrm{~F}$ & G & $\mathrm{H}$ & I & & & & & & \\
\hline DG55 & 1 & far. & 117,73 & & & & & & & G & $\mathrm{H}$ & 1 & $\mathrm{~J}$ & & & & & \\
\hline MANT & IAC & mesa & 116,55 & & & & & & & G & $\mathrm{H}$ & I & $\mathrm{J}$ & $\mathrm{K}$ & & & & \\
\hline DG71 & 1 & far. & 110,24 & & & & & & & G & $\mathrm{H}$ & I & $\mathrm{J}$ & $\mathrm{K}$ & L & & & \\
\hline DG119 & 2 & far. & 107,85 & & & & & & & G & $\mathrm{H}$ & I & $\mathrm{J}$ & $\mathrm{K}$ & $\mathrm{L}$ & $\mathrm{M}$ & & \\
\hline DG38 & 1 & far. & 104,84 & & & & & & & G & $\mathrm{H}$ & 1 & $\mathrm{~J}$ & $\mathrm{~K}$ & $\mathrm{~L}$ & $\mathrm{M}$ & $\mathrm{N}$ & \\
\hline DG124 & 2 & far. & 104,59 & & & & & & & G & $\mathrm{H}$ & I & $\mathrm{J}$ & $\mathrm{K}$ & $\mathrm{L}$ & $\mathrm{M}$ & $\mathrm{N}$ & \\
\hline DG62 & 1 & far. & 101.97 & & & & & & & & $\mathrm{H}$ & 1 & $\mathrm{~J}$ & $\mathrm{~K}$ & L & $M$ & $\mathrm{~N}$ & \\
\hline DG47 & 1 & far. & 101,49 & & & & & & & & $\mathrm{H}$ & I & $\mathrm{J}$ & $\mathrm{K}$ & $\mathrm{L}$ & $\mathrm{M}$ & $\mathrm{N}$ & \\
\hline DG132 & 3 & mesa & 99,97 & & & & & & & & $\mathrm{H}$ & I & $\mathrm{J}$ & $\mathrm{K}$ & $\mathrm{L}$ & $M$ & $\mathrm{~N}$ & $\mathrm{O}$ \\
\hline DG113 & 2 & far. & 95,74 & & & & & & & & $\mathrm{H}$ & I & $\mathrm{J}$ & $\mathrm{K}$ & $\mathrm{L}$ & $M$ & $\mathrm{~N}$ & $\mathrm{O}$ \\
\hline DG112 & 2 & far. & 95,48 & & & & & & & & $\mathrm{H}$ & 1 & $\mathrm{~J}$ & $\mathrm{~K}$ & $\mathrm{~L}$ & $\mathrm{M}$ & $\mathrm{N}$ & $\mathrm{O}$ \\
\hline DG118 & 2 & far. & 95,14 & & & & & & & & $\mathrm{H}$ & I & $\mathrm{J}$ & $\mathrm{K}$ & $\mathrm{L}$ & $M$ & $\mathrm{~N}$ & $\mathrm{O}$ \\
\hline DG125 & 2 & far. & 91,45 & & & & & & & & & I & $\mathrm{J}$ & $\mathrm{K}$ & $\mathrm{L}$ & $\mathrm{M}$ & $\mathrm{N}$ & $\mathrm{O}$ \\
\hline DG70 & 1 & far. & 89,89 & & & & & & & & & $I$ & $J$ & $\mathrm{~K}$ & $\mathrm{~L}$ & $M$ & $\mathrm{~N}$ & $\mathrm{O}$ \\
\hline DG127 & 3 & far. & 87.32 & & & & & & & & & I & $\mathrm{J}$ & $\mathrm{K}$ & $\mathrm{L}$ & $M$ & $\mathrm{~N}$ & $\mathrm{O}$ \\
\hline DG122 & 2 & far. & 87,32 & & & & & & & & & I & $\mathrm{J}$ & $\mathrm{K}$ & $\mathrm{L}$ & $M$ & $\mathrm{~N}$ & $\mathrm{O}$ \\
\hline DG129 & 3 & mesa & 86,41 & & & & & & & & & I & $\mathrm{J}$ & $\mathrm{K}$ & L & $\mathrm{M}$ & $\mathrm{N}$ & $\mathrm{O}$ \\
\hline DG138 & 2 & far. & 85,69 & & & & & & & & & 1 & $\mathrm{~J}$ & $\mathrm{~K}$ & $\mathrm{~L}$ & $\mathrm{M}$ & $\mathrm{N}$ & $\mathrm{O}$ \\
\hline DG128 & 3 & mesa & 85.22 & & & & & & & & & I & $\mathrm{J}$ & $\mathrm{K}$ & $\mathrm{L}$ & $M$ & $\mathrm{~N}$ & $\mathrm{O}$ \\
\hline DG46 & 1 & far. & 84,24 & & & & & & & & & I & $\mathrm{J}$ & $\mathrm{K}$ & $\mathrm{L}$ & M & $\mathrm{N}$ & $\mathrm{O}$ \\
\hline DG111 & 2 & far. & 82,83 & & & & & & & & & 1 & $\mathrm{~J}$ & $\mathrm{~K}$ & $\mathrm{~L}$ & $M$ & $\mathrm{~N}$ & $\mathrm{O}$ \\
\hline DG65 & 1 & far. & 78,34 & & & & & & & & & & $\mathrm{~J}$ & $\mathrm{~K}$ & $\mathrm{~L}$ & $M$ & $\mathrm{~N}$ & $\mathrm{O}$ \\
\hline DG41 & 1 & far. & 78,01 & & & & & & & & & & $\mathrm{~J}$ & $\mathrm{~K}$ & $\mathrm{~L}$ & $M$ & $\mathrm{~N}$ & $\mathrm{O}$ \\
\hline DG131 & 3 & mesa & 73,25 & & & & & & & & & & $\mathrm{~J}$ & $\mathrm{~K}$ & $\mathrm{~L}$ & $M$ & $\mathrm{~N}$ & $\mathrm{O}$ \\
\hline DG67 & 1 & far. & 69,48 & & & & & & & & & & $\mathrm{~J}$ & $\mathrm{~K}$ & $\mathrm{~L}$ & $\mathrm{M}$ & $\mathrm{N}$ & $\mathrm{O}$ \\
\hline DG56 & 1 & far. & 69,25 & & & & & & & & & & $\mathrm{~J}$ & $\mathrm{~K}$ & $\mathrm{~L}$ & $M$ & $\mathrm{~N}$ & $\mathrm{O}$ \\
\hline DG58 & 1 & far. & 65.97 & & & & & & & & & & $\mathrm{~J}$ & $\mathrm{~K}$ & $\mathrm{~L}$ & $M$ & $\mathrm{~N}$ & $\mathrm{O}$ \\
\hline DG61 & 1 & far. & 65,76 & & & & & & & & & & $\mathrm{~J}$ & $\mathrm{~K}$ & $\mathrm{~L}$ & $\mathrm{M}$ & $\mathrm{N}$ & $\mathrm{O}$ \\
\hline DG50 & 1 & far. & 64,86 & & & & & & & & & & $\mathrm{~J}$ & $\mathrm{~K}$ & $\mathrm{~L}$ & $M$ & $\mathrm{~N}$ & $\mathrm{O}$ \\
\hline DG45 & 1 & mesa & 64,68 & & & & & & & & & & $\mathrm{~J}$ & $\mathrm{~K}$ & $\mathrm{~L}$ & $\mathrm{M}$ & $\mathrm{N}$ & $\mathrm{O}$ \\
\hline DG39 & 1 & mesa & 64,20 & & & & & & & & & & $\mathrm{~J}$ & $\mathrm{~K}$ & $\mathrm{~L}$ & M & $\mathrm{N}$ & $\mathrm{O}$ \\
\hline DG59 & 1 & far. & 62,24 & & & & & & & & & & $\mathrm{~J}$ & $\mathrm{~K}$ & $\mathrm{~L}$ & $M$ & $\mathrm{~N}$ & $\mathrm{O}$ \\
\hline DG49 & 1 & far. & 61,72 & & & & & & & & & & & $\mathrm{~K}$ & $\mathrm{~L}$ & $M$ & $\mathrm{~N}$ & $\mathrm{O}$ \\
\hline DG123 & 2 & far. & 60,03 & & & & & & & & & & & & $\mathrm{~L}$ & $M$ & $\mathrm{~N}$ & $\mathrm{O}$ \\
\hline DG54 & 1 & far. & 58.91 & & & & & & & & & & & & $\mathrm{~L}$ & $M$ & $\mathrm{~N}$ & $\mathrm{O}$ \\
\hline DG52 & 1 & far. & 54,43 & & & & & & & & & & & & & $M$ & $\mathrm{~N}$ & $\mathrm{O}$ \\
\hline DG40 & 1 & far. & 53,56 & & & & & & & & & & & & & $M$ & $\mathrm{~N}$ & $\mathrm{O}$ \\
\hline DG51 & 1 & far. & 51,23 & & & & & & & & & & & & & & $\mathrm{~N}$ & $\mathrm{O}$ \\
\hline DG68 & 1 & far. & 45.68 & & & & & & & & & & & & & & & $\mathrm{O}$ \\
\hline
\end{tabular}


Tabela 25 . Teste de Tukey a $5 \%$ de probabilidade, variável 35 ácido cianídrico livre na entrecasca da raiz, em $\mathrm{mg} / \mathrm{kg}$ na base seca , $\Delta_{5 \%}=5,385$.

\begin{tabular}{|c|c|c|c|c|c|c|c|c|c|c|c|c|c|c|c|c|c|c|c|c|}
\hline Etnov. & Reg. & Uso & Média & $\mathrm{A}$ & B & $\mathrm{C}$ & $\mathrm{D}$ & $E$ & $\mathrm{~F}$ & $G$ & $\mathrm{H}$ & I & $\mathrm{J}$ & $\mathrm{K}$ & $\mathrm{L}$ & $\mathrm{M}$ & $\mathrm{N}$ & $\mathrm{O}$ & $P$ & $\bar{Q}$ \\
\hline DG116 & 2 & far. & 31.377 & $\mathrm{~A}$ & & & & & & & & & & & & & & & & \\
\hline DG126 & 3 & far. & 30,947 & $\mathrm{~A}$ & B & & & & & & & & & & & & & & & \\
\hline DG44 & 1 & far. & 29,963 & $\mathrm{~A}$ & B & & & & & & & & & & & & & & & \\
\hline DG42 & 1 & far. & 28,130 & A & B & & & & & & & & & & & & & & & \\
\hline DG43 & 1 & far. & 27.607 & A & B & C & & & & & & & & & & & & & & \\
\hline DG134 & 3 & mesa & 25,790 & & B & $\mathrm{C}$ & D & & & & & & & & & & & & & \\
\hline DG73 & 1 & far. & 22,557 & & & $\mathrm{C}$ & $\mathrm{D}$ & $\mathrm{E}$ & & & & & & & & & & & & \\
\hline DG114 & 2 & far. & 22.183 & & & & $\mathrm{D}$ & $\mathrm{E}$ & $\mathrm{F}$ & & & & & & & & & & & \\
\hline DG117 & 2 & far. & 19.840 & & & & & $\mathrm{E}$ & $\mathrm{F}$ & G & & & & & & & & & & \\
\hline DG133 & 3 & mesa & 19,247 & & & & & $E$ & $\mathrm{~F}$ & $G$ & & & & & & & & & & \\
\hline DG121 & 2 & far. & 19,213 & & & & & $\mathrm{E}$ & $\mathrm{F}$ & $G$ & & & & & & & & & & \\
\hline DG115 & 2 & far. & 19,050 & & & & & $\mathrm{E}$ & $\mathrm{F}$ & $G$ & & & & & & & & & & \\
\hline DG130 & 3 & mesa & 18.023 & & & & & $E$ & $\mathrm{~F}$ & G & $\mathrm{H}$ & & & & & & & & & \\
\hline DG60 & 1 & far. & 17,033 & & & & & & $\mathrm{~F}$ & G & $\mathrm{H}$ & I & & & & & & & & \\
\hline DG120 & 2 & far. & 15,447 & & & & & & & G & $\mathrm{H}$ & I & $J$ & & & & & & & \\
\hline DG69 & 1 & far. & 13,347 & & & & & & & & $\mathrm{H}$ & I & $J$ & $\mathrm{~K}$ & & & & & & \\
\hline MANT & IAC & mesa & 13.203 & & & & & & & & $\mathrm{H}$ & 1 & $J$ & $\mathrm{~K}$ & $\mathrm{~L}$ & & & & & \\
\hline DG48 & 1 & far. & 11,780 & & & & & & & & & I & $\mathrm{J}$ & $\mathrm{K}$ & $\mathrm{L}$ & $\mathrm{M}$ & & & & \\
\hline DG5S & 1 & far. & 11,473 & & & & & & & & & & $\mathrm{~J}$ & $\mathrm{~K}$ & $\mathrm{~L}$ & $\mathrm{M}$ & & & & \\
\hline DG71 & 1 & far. & 10,613 & & & & & & & & & & $J$ & $\mathrm{~K}$ & $\mathrm{~L}$ & $M$ & $\mathrm{~N}$ & & & \\
\hline DG1 19 & 2 & far. & 10,553 & & & & & & & & & & $\mathrm{~J}$ & $\mathrm{~K}$ & $\mathrm{~L}$ & $M$ & $\mathrm{~N}$ & & & \\
\hline DG128 & 3 & mesa & 10,010 & & & & & & & & & & & $\mathrm{~K}$ & $\mathrm{~L}$ & $\mathrm{M}$ & $\mathrm{N}$ & $\mathrm{O}$ & & \\
\hline DG124 & 2 & far. & 9,810 & & & & & & & & & & & $\mathrm{~K}$ & $\mathrm{~L}$ & $\mathrm{M}$ & $\mathrm{N}$ & $\mathrm{O}$ & $\mathrm{P}$ & \\
\hline DG38 & 1 & far. & 9,783 & & & & & & & & & & & $\mathrm{~K}$ & L & $\mathrm{M}$ & $\mathrm{N}$ & $\mathrm{O}$ & $P$ & \\
\hline DG1 18 & 2 & far. & 9,497 & & & & & & & & & & & K & $\mathrm{L}$ & M & $\mathrm{N}$ & $\mathrm{O}$ & $P$ & \\
\hline DG125 & 2 & far. & 9,333 & & & & & & & & & & & $\mathrm{~K}$ & $\mathrm{~L}$ & $\mathrm{M}$ & $\mathrm{N}$ & $\mathrm{O}$ & P & $\mathrm{Q}$ \\
\hline DG132 & 3 & mesa & 9,000 & & & & & & & & & & & $\mathrm{~K}$ & $\mathrm{~L}$ & $\mathrm{M}$ & $\mathrm{N}$ & $\mathrm{O}$ & $P$ & Q \\
\hline DG46 & 1 & far. & 8.977 & & & & & & & & & & & $\mathrm{~K}$ & $\mathrm{~L}$ & $M$ & $\mathrm{~N}$ & $\mathrm{O}$ & P & Q \\
\hline DG138 & 2 & far. & 8,903 & & & & & & & & & & & K & $\mathrm{L}$ & $\mathrm{M}$ & $\mathrm{N}$ & $\mathrm{O}$ & $P$ & $\mathrm{Q}$ \\
\hline DG47 & 1 & far. & 8,717 & & & & & & & & & & & $\mathrm{~K}$ & $\mathrm{~L}$ & $M$ & $\mathrm{~N}$ & $\mathrm{O}$ & $\mathrm{P}$ & $Q$ \\
\hline DG1 12 & 2 & far. & 8,603 & & & & & & & & & & & $\mathrm{~K}$ & $\mathrm{~L}$ & $\mathrm{M}$ & $\mathrm{N}$ & $\mathrm{O}$ & $\mathrm{P}$ & $\mathrm{Q}$ \\
\hline DG129 & 3 & mesa & 8,257 & & & & & & & & & & & $\mathrm{~K}$ & $\mathrm{~L}$ & $\mathrm{M}$ & $\mathrm{N}$ & $\mathrm{O}$ & $P$ & $\mathrm{Q}$ \\
\hline DG62 & 1 & far. & 8,210 & & & & & & & & & & & $\mathrm{~K}$ & $\mathrm{~L}$ & $\mathrm{M}$ & $\mathrm{N}$ & $\mathrm{O}$ & $\mathrm{P}$ & $\mathrm{Q}$ \\
\hline DG113 & 2 & far. & 7,930 & & & & & & & & & & & & $\mathrm{~L}$ & $\mathrm{M}$ & $\mathrm{N}$ & $\mathrm{O}$ & $\mathrm{P}$ & $\mathrm{Q}$ \\
\hline DG70 & 1 & far. & 7.867 & & & & & & & & & & & & $\mathrm{~L}$ & $\mathrm{M}$ & $\mathrm{N}$ & $\mathrm{O}$ & $P$ & $\mathrm{Q}$ \\
\hline DG111 & 2 & far. & 7,683 & & & & & & & & & & & & & $\mathrm{M}$ & $\mathrm{N}$ & $\mathrm{O}$ & $P$ & Q \\
\hline DG56 & 1 & far. & 7,630 & & & & & & & & & & & & & $\mathrm{M}$ & $\mathrm{N}$ & $\mathrm{O}$ & $P$ & Q \\
\hline DG127 & 3 & far. & 7,430 & & & & & & & & & & & & & $\mathrm{M}$ & $\mathrm{N}$ & $\mathrm{O}$ & $\mathrm{P}$ & $\mathrm{Q}$ \\
\hline DG67 & 1 & far. & 7,340 & & & & & & & & & & & & & $\mathrm{M}$ & $\mathrm{N}$ & $\mathrm{O}$ & $P$ & $\mathrm{Q}$ \\
\hline DG122 & 2 & far. & 7.110 & & & & & & & & & & & & & $\mathrm{M}$ & $\mathrm{N}$ & $\mathrm{O}$ & $\mathrm{P}$ & Q \\
\hline DG58 & 1 & far. & 6,853 & & & & & & & & & & & & & $\mathrm{M}$ & $\mathrm{N}$ & $\mathrm{O}$ & $P$ & $Q$ \\
\hline DG65 & 1 & far. & 6,790 & & & & & & & & & & & & & $\mathrm{M}$ & $N$ & $\mathrm{O}$ & $P$ & $\mathrm{Q}$ \\
\hline DG131 & 3 & mesa & 6,543 & & & & & & & & & & & & & $M$ & $\mathrm{~N}$ & $\mathrm{O}$ & $P$ & $\mathrm{Q}$ \\
\hline DG41 & 1 & far. & 6.517 & & & & & & & & & & & & & $M$ & $\mathrm{~N}$ & $\mathrm{O}$ & $\mathrm{P}$ & $\mathrm{Q}$ \\
\hline DG123 & 2 & far. & 6,417 & & & & & & & & & & & & & $\mathrm{M}$ & $\mathrm{N}$ & $\mathrm{O}$ & $\mathrm{P}$ & $\mathrm{Q}$ \\
\hline DG40 & 1 & far. & 6,020 & & & & & & & & & & & & & &. $\mathrm{~V}$ & $\mathrm{O}$ & $\mathrm{P}$ & $\mathrm{Q}$ \\
\hline DG45 & 1 & mesa & 5,807 & & & & & & & & & & & & & & $\mathrm{~N}$ & $\mathrm{O}$ & $\mathrm{P}$ & Q \\
\hline DG54 & 1 & far. & 5.570 & & & & & & & & & & & & & & $\mathrm{~N}$ & $\mathrm{O}$ & $\mathrm{P}$ & $\mathrm{Q}$ \\
\hline DG61 & 1 & far. & 5,563 & & & & & & & & & & & & & & $\mathrm{~N}$ & $\mathrm{O}$ & $\mathrm{P}$ & $\mathrm{Q}$ \\
\hline DG39 & 1 & mesa & 5.533 & & & & & & & & & & & & & &. $\mathrm{~V}$ & $\mathrm{O}$ & $P$ & Q \\
\hline DG5 1 & 1 & far. & 5,117 & & & & & & & & & & & & & & & $\mathrm{O}$ & $P$ & Q \\
\hline DGS0 & 1 & far. & 5,093 & & & & & & & & & & & & & & & $\mathrm{O}$ & $P$ & $\mathrm{Q}$ \\
\hline DG52 & 1 & far. & 5,090 & & & & & & & & & & & & & & & $\mathrm{O}$ & $\mathrm{P}$ & Q \\
\hline DG49 & 1 & far. & 4,853 & & & & & & & & & & & & & & & $\mathrm{O}$ & $P$ & Q \\
\hline DG59 & 1 & far. & 4,613 & & & & & & & & & & & & & & & & $\mathrm{P}$ & $\mathrm{Q}$ \\
\hline DG68 & 1 & far. & 3,990 & & & & & & & & & & & & & & & & & $\mathrm{Q}$ \\
\hline
\end{tabular}


Tabela 26. Teste de Tukey a 5\% de probabilidade, variável 36 potencial cianogênico na polpa da raiz. em $\mathrm{mg} / \mathrm{kg}$ na base seca $, \Delta_{5 \%}=21,650$.

\begin{tabular}{|c|c|c|c|c|c|c|c|c|c|c|c|c|c|c|c|c|c|c|c|c|c|c|}
\hline Etnov. & Reg. & Uso & Média & $A$ & B & $\mathrm{C}$ & $\mathrm{D}$ & $E$ & $\mathrm{~F}$ & G & $\mathrm{H}$ & $I$ & $J$ & $\mathrm{~K}$ & $\mathrm{~L}$ & $\mathrm{M}$ & $\mathrm{N}$ & $\mathrm{O}$ & $P$ & Q & $\mathrm{R}$ & $\mathrm{S}$ \\
\hline DG44 & 1 & far. & 89,450 & A & & & & & & & & & & & & & & & & & & \\
\hline DG47 & 1 & far. & 75,353 & $A$ & B & & & & & & & & & & & & & & & & & \\
\hline DG126 & 3 & far. & 55,383 & & B & C & & & & & & & & & & & & & & & & \\
\hline DG43 & 1 & far. & 54,260 & & B & C & $\mathrm{D}$ & & & & & & & & & & & & & & & \\
\hline DG38 & 1 & far. & 53,370 & & & $\mathrm{C}$ & $\mathrm{D}$ & E & & & & & & & & & & & & & & \\
\hline DG71 & 1 & far. & 50,577 & & & C & D & E & $\mathrm{F}$ & & & & & & & & & & & & & \\
\hline DG41 & 1 & far. & 49.823 & & & $\mathrm{C}$ & $\mathrm{D}$ & $\mathrm{E}$ & $\mathrm{F}$ & G & & & & & & & & & & & & \\
\hline DG55 & 1 & far. & 49,627 & & & C & D & $E$ & $\mathrm{~F}$ & G & & & & & & & & & & & & \\
\hline DG73 & 1 & far. & 49.297 & & & C & D & $\mathrm{E}$ & $\mathrm{F}$ & G & $\mathrm{H}$ & & & & & & & & & & & \\
\hline DG46 & 1 & far. & 47.753 & & & $\mathrm{C}$ & $D$ & $E$ & $\mathrm{~F}$ & G & $\mathrm{H}$ & I & & & & & & & & & & \\
\hline DG39 & 1 & mesa & 47.580 & & & $\mathrm{C}$ & $\mathrm{D}$ & $\mathrm{E}$ & $\mathrm{F}$ & G & $\mathrm{H}$ & I & & & & & & & & & & \\
\hline DG67 & 1 & far. & 42.697 & & & C & D & E & $\mathrm{F}$ & G & $\mathrm{H}$ & I & $\mathrm{J}$ & & & & & & & & & \\
\hline DG122 & 2 & far. & 41.887 & & & $\mathrm{C}$ & $\mathrm{D}$ & $E$ & $\mathrm{~F}$ & G & $\mathrm{H}$ & I & $\mathrm{J}$ & $\mathrm{K}$ & & & & & & & & \\
\hline DG129 & 3 & mesa & 40.827 & & & C & D & $\mathrm{E}$ & $\mathrm{F}$ & G & $\mathrm{H}$ & I & $\mathrm{J}$ & $\mathrm{K}$ & L & & & & & & & \\
\hline DG121 & 2 & far. & 39,050 & & & C & D & $E$ & $\mathrm{~F}$ & G & $\mathrm{H}$ & I & $\mathrm{J}$ & $\mathrm{K}$ & L & $\mathrm{M}$ & & & & & & \\
\hline DG116 & 2 & far. & 37,507 & & & C & D & $E$ & $\mathrm{~F}$ & G & $\mathrm{H}$ & I & $\mathrm{J}$ & $\mathrm{K}$ & L & $M$ & $N$ & & & & & \\
\hline DG128 & 3 & mesa & 36,437 & & & $\mathrm{C}$ & $\mathrm{D}$ & $E$ & $\mathrm{~F}$ & G & $\mathrm{H}$ & 1 & $\mathrm{~J}$ & $\mathrm{~K}$ & $\mathrm{~L}$ & $M$ & $N$ & & & & & \\
\hline DG51 & 1 & far. & 35.960 & & & $\mathrm{C}$ & $\mathrm{D}$ & $E$ & $\mathrm{~F}$ & G & $\mathrm{H}$ & I & $\mathrm{J}$ & $\mathrm{K}$ & $\mathrm{L}$ & $\mathrm{M}$ & $\mathrm{N}$ & & & & & \\
\hline DG114 & 2 & far. & 34,700 & & & C & $\mathrm{D}$ & $\mathrm{E}$ & $\mathrm{F}$ & G & $\mathrm{H}$ & I & $\mathrm{J}$ & $\mathrm{K}$ & $\mathrm{L}$ & $\mathrm{M}$ & $\mathrm{N}$ & $\mathrm{O}$ & & & & \\
\hline DG54 & 1 & far. & 34,530 & & & C & D & $E$ & $\mathrm{~F}$ & G & $\mathrm{H}$ & I & $\mathrm{J}$ & $\mathrm{K}$ & L & $\mathrm{M}$ & $\mathrm{N}$ & $\mathrm{O}$ & & & & \\
\hline DG49 & 1 & far. & 32,810 & & & & $\mathrm{D}$ & $E$ & $\mathrm{~F}$ & G & $\mathrm{H}$ & I & $\mathrm{J}$ & $\mathrm{K}$ & $\mathrm{L}$ & $M$ & $\mathrm{~N}$ & $\mathrm{O}$ & $P$ & & & \\
\hline DG134 & 3 & mesa & 32.130 & & & & & $E$ & $\mathrm{~F}$ & G & $\mathrm{H}$ & I & $\mathrm{J}$ & $\mathrm{K}$ & $\mathrm{L}$ & $M$ & $\mathrm{~N}$ & $\mathrm{O}$ & $\mathrm{P}$ & & & \\
\hline DG48 & 1 & far. & 31,297 & & & & & & $\mathrm{~F}$ & G & $\mathrm{H}$ & I & $\mathrm{J}$ & $\mathrm{K}$ & $\mathrm{L}$ & $\mathrm{M}$ & $\mathrm{N}$ & $\mathrm{O}$ & $P$ & Q & & \\
\hline DG40 & 1 & far. & 30,140 & & & & & & $\mathrm{~F}$ & G & $\mathrm{H}$ & I & $\mathrm{J}$ & $\mathrm{K}$ & $\mathrm{L}$ & $\mathrm{M}$ & $\mathrm{N}$ & $\mathrm{O}$ & $P$ & $\mathrm{Q}$ & $\mathrm{R}$ & \\
\hline DG112 & 2 & far. & 29,307 & & & & & & $\mathrm{~F}$ & G & $\mathrm{H}$ & I & $\mathrm{J}$ & $\mathrm{K}$ & L & $\mathrm{M}$ & $\mathrm{N}$ & $\mathrm{O}$ & $\mathrm{P}$ & Q & $\mathrm{R}$ & $\mathrm{S}$ \\
\hline DG133 & 3 & mesa & 29,017 & & & & & & $\mathrm{~F}$ & G & $\mathrm{H}$ & I & $\mathrm{J}$ & $\mathrm{K}$ & $\mathrm{L}$ & $\mathrm{M}$ & $\mathrm{N}$ & $\mathrm{O}$ & $P$ & Q & $\mathrm{R}$ & $S$ \\
\hline DG111 & 2 & far. & 28,947 & & & & & & $\mathrm{~F}$ & G & $\mathrm{H}$ & I & $J$ & $\mathrm{~K}$ & $\mathrm{~L}$ & $\mathrm{M}$ & $\mathbf{N}$ & $\mathrm{O}$ & $P$ & Q & $\mathrm{R}$ & $S$ \\
\hline DG138 & 2 & far. & 28,583 & & & & & & & G & $\mathrm{H}$ & I & $\mathrm{J}$ & $\mathrm{K}$ & $\mathrm{L}$ & M & $\mathrm{N}$ & $\mathrm{O}$ & $\mathrm{P}$ & Q & $\mathrm{R}$ & $S$ \\
\hline DG45 & 1 & mesa & 27,710 & & & & & & & & $\mathrm{H}$ & I & $\mathrm{J}$ & $\mathrm{K}$ & $\mathrm{L}$ & $\mathrm{M}$ & $\mathrm{N}$ & $\mathrm{O}$ & $P$ & Q & $\mathrm{R}$ & $S$ \\
\hline DG56 & 1 & far. & 27.187 & & & & & & & & & I & $\mathrm{J}$ & $\mathrm{K}$ & $\mathrm{L}$ & $\mathrm{M}$ & $\mathrm{N}$ & $\mathrm{O}$ & $P$ & $\mathrm{Q}$ & $\mathrm{R}$ & $S$ \\
\hline DG70 & 1 & far. & 26,470 & & & & & & & & & I & $\mathrm{J}$ & $\mathrm{K}$ & $\mathrm{L}$ & $\mathrm{M}$ & $\mathrm{N}$ & $\mathrm{O}$ & $P$ & $\mathrm{Q}$ & $\mathrm{R}$ & $S$ \\
\hline DG60 & 1 & far. & 26,377 & & & & & & & & & I & $\mathrm{J}$ & $\mathrm{K}$ & $\mathrm{L}$ & $\mathrm{M}$ & $\mathrm{N}$ & $\mathrm{O}$ & $\mathrm{P}$ & Q & $\mathrm{R}$ & $\mathrm{S}$ \\
\hline DG115 & 2 & far. & 25,707 & & & & & & & & & & $\mathrm{~J}$ & $\mathrm{~K}$ & $\mathrm{~L}$ & $\mathrm{M}$ & $\mathrm{N}$ & $\mathrm{O}$ & $P$ & Q & $\mathrm{R}$ & $S$ \\
\hline DG59 & 1 & far. & 24.093 & & & & & & & & & & $\mathrm{~J}$ & $\mathrm{~K}$ & $\mathrm{~L}$ & $\mathrm{M}$ & $\mathrm{N}$ & $\mathrm{O}$ & P & Q & $\mathrm{R}$ & S \\
\hline DG123 & 2 & far. & 23,853 & & & & & & & & & & $\mathrm{~J}$ & $\mathrm{~K}$ & $\mathrm{~L}$ & $\mathrm{M}$ & $\mathrm{N}$ & $\mathrm{O}$ & $\mathrm{P}$ & $Q$ & $\mathrm{R}$ & $S$ \\
\hline DG50 & 1 & far. & 22,633 & & & & & & & & & & $\mathrm{~J}$ & $\mathrm{~K}$ & L & M & $\mathrm{N}$ & $\mathrm{O}$ & P & Q & $\mathrm{R}$ & $\mathrm{S}$ \\
\hline DG125 & 2 & far. & 22,410 & & & & & & & & & & $\mathrm{~J}$ & $\mathrm{~K}$ & L & $\mathrm{M}$ & $\mathrm{N}$ & $\mathrm{O}$ & $\mathrm{P}$ & Q & $\mathrm{R}$ & $\mathrm{S}$ \\
\hline DG62 & 1 & far. & 20,763 & & & & & & & & & & & $\mathrm{~K}$ & $\mathrm{~L}$ & $\mathrm{M}$ & $\mathrm{N}$ & $\mathrm{O}$ & P & Q & $\mathrm{R}$ & $\mathrm{S}$ \\
\hline DG119 & 2 & far. & 20,467 & & & & & & & & & & & $\mathrm{~K}$ & $\mathrm{~L}$ & $\mathrm{M}$ & $\mathrm{N}$ & $\mathrm{O}$ & $\mathrm{P}$ & Q & $\mathrm{R}$ & $S$ \\
\hline DG65 & 1 & far. & 19,740 & & & & & & & & & & & & $\mathrm{~L}$ & $\mathrm{M}$ & $\mathrm{N}$ & $\mathrm{O}$ & $\mathrm{P}$ & $Q$ & $\mathrm{R}$ & $S$ \\
\hline DG113 & 2 & far. & 19,630 & & & & & & & & & & & & $\mathrm{~L}$ & $\mathrm{M}$ & $\mathrm{N}$ & $\mathrm{O}$ & $P$ & $Q$ & $\mathrm{R}$ & $S$ \\
\hline DG42 & 1 & far. & 18.680 & & & & & & & & & & & & & $\mathrm{M}$ & $\mathrm{N}$ & $\mathrm{O}$ & $\mathrm{P}$ & $Q$ & $\mathrm{R}$ & $\mathrm{S}$ \\
\hline DG124 & 2 & far. & 18,243 & & & & & & & & & & & & & $\mathrm{M}$ & $\mathrm{N}$ & $\mathrm{O}$ & $P$ & Q & $\mathrm{R}$ & $\mathrm{S}$ \\
\hline DG132 & 3 & mesa & 18,110 & & & & & & & & & & & & & $\mathrm{M}$ & $\mathrm{N}$ & $\mathrm{O}$ & $\mathrm{P}$ & Q & $\mathrm{R}$ & $\mathrm{S}$ \\
\hline DG69 & 1 & far. & 17.387 & & & & & & & & & & & & & & $\mathrm{~N}$ & $\mathrm{O}$ & P & Q & $\mathrm{R}$ & $\mathrm{S}$ \\
\hline DG117 & 2 & far. & 17,367 & & & & & & & & & & & & & & $\mathbf{N}$ & $\mathrm{O}$ & $\mathrm{P}$ & Q & $\mathrm{R}$ & $\mathrm{S}$ \\
\hline DG52 & 1 & far. & 16,057 & & & & & & & & & & & & & & $\mathrm{~N}$ & $\mathrm{O}$ & $P$ & $Q$ & $\mathrm{R}$ & $\mathrm{S}$ \\
\hline DG127 & 3 & far. & 15,913 & & & & & & & & & & & & & & $\mathrm{~N}$ & $\mathrm{O}$ & $P$ & Q & $\mathrm{R}$ & $\mathrm{S}$ \\
\hline DG120 & 2 & far. & 13,777 & & & & & & & & & & & & & & & $\mathrm{O}$ & $\mathrm{P}$ & Q & $\mathrm{R}$ & $\mathrm{S}$ \\
\hline DG130 & 3 & mesa & 11.843 & & & & & & & & & & & & & & & & P & Q & $\mathrm{R}$ & $\mathrm{S}$ \\
\hline DG68 & 1 & far. & 11,803 & & & & & & & & & & & & & & & & $P$ & $\mathrm{Q}$ & $\mathrm{R}$ & $S$ \\
\hline DG58 & 1 & far. & 11.580 & & & & & & & & & & & & & & & & $P$ & Q & $\mathrm{R}$ & $S$ \\
\hline DG118 & 2 & far. & 10,143 & & & & & & & & & & & & & & & & & Q & $\mathrm{R}$ & $S$ \\
\hline MANT & IAC & mesa & 9.503 & & & & & & & & & & & & & & & & & & $\mathrm{R}$ & $\mathrm{S}$ \\
\hline DG131 & 3 & mesa & 8,907 & & & & & & & & & & & & & & & & & & $\mathrm{R}$ & $\mathrm{S}$ \\
\hline DG61 & 1 & far. & 8.410 & & & & & & & & & & & & & & & & & & & $\mathrm{~S}$ \\
\hline
\end{tabular}

Região 1: Rio Negro - Bacia Amazònica

Região 2: Rio Solimões - Bacia Amazònica

Região 3: Litoral 5ul - SP 
Tabela 27. Teste de Tukey a 5\% de probabilidade, variável 37 ácido cianidrico livre na polpa da raiz, em $\mathrm{mg} / \mathrm{kg}$ na base seca, $\Delta_{\$ \%}=2,7636$.

\begin{tabular}{|c|c|c|c|c|c|c|c|c|c|c|c|c|c|c|c|c|}
\hline Etnov. & Reg & Uso & Média & $A$ & $\mathrm{~B}$ & $\mathrm{C}$ & $\mathrm{D}$ & $E$ & $F$ & $G$ & $\mathrm{H}$ & I & $\mathrm{J}$ & $\mathrm{K}$ & $\mathrm{L}$ & $\mathrm{M}$ \\
\hline DG44 & 1 & far. & 7,807 & $A$ & & & & & & & & & & & & \\
\hline DG47 & 1 & far. & 7,783 & $A$ & & & & & & & & & & & & \\
\hline DG126 & 3 & far. & 6.053 & $A$ & B & & & & & & & & & & & \\
\hline DG46 & 1 & far. & 5,723 & $A$ & B & C & & & & & & & & & & \\
\hline DG41 & 1 & far. & 5.640 & $A$ & B & C & & & & & & & & & & \\
\hline DG43 & $i$ & far. & 5,120 & $A$ & B & C & D & & & & & & & & & \\
\hline DG73 & $i$ & far. & 5,047 & $A$ & B & C & $\mathrm{D}$ & $E$ & & & & & & & & \\
\hline DG55 & 1 & far. & 4,963 & & B & C & $\mathrm{D}$ & $E$ & $\mathrm{~F}$ & & & & & & & \\
\hline DG71 & 1 & far. & 4.943 & & B & C & $\mathrm{D}$ & E & $\mathrm{F}$ & G & & & & & & \\
\hline DG122 & 2 & far. & 4.777 & & B & C & $\mathrm{D}$ & $E$ & $\mathrm{~F}$ & G & $\mathrm{H}$ & & & & & \\
\hline DG38 & 1 & far. & 4.583 & & B & C & D & $E$ & $\mathrm{~F}$ & G & $\mathrm{H}$ & I & & & & \\
\hline DG39 & 1 & mesa & 4.507 & & B & C & D & $E$ & $\mathrm{~F}$ & G & $\mathrm{H}$ & 1 & & & & \\
\hline DG128 & 3 & mesa & 4.230 & & B & C & D & E & $\mathrm{F}$ & G & $\mathrm{H}$ & I & $J$ & & & \\
\hline DG48 & 1 & far. & 4.080 & & B & C & D & E & $\mathrm{F}$ & G & $\mathrm{H}$ & I & $\mathrm{J}$ & $\mathrm{K}$ & & \\
\hline DG40 & 1 & far. & 3.980 & & B & C & $\mathrm{D}$ & $E$ & $\mathrm{~F}$ & G & $\mathrm{H}$ & I & $\mathrm{J}$ & $\mathrm{K}$ & $\mathrm{L}$ & \\
\hline DG67 & 1 & far. & 3,667 & & B & C & $\mathrm{D}$ & $E$ & $\mathrm{~F}$ & G & $\mathrm{H}$ & I & $\mathrm{J}$ & $\mathrm{K}$ & $\mathrm{L}$ & $\mathrm{M}$ \\
\hline DG116 & 2 & far. & 3.647 & & B & C & D & $E$ & $\mathrm{~F}$ & G & $\mathrm{H}$ & I & $\mathrm{J}$ & $\mathrm{K}$ & $\mathrm{L}$ & $M$ \\
\hline DG54 & 1 & far. & 3,387 & & B & C & $\mathrm{D}$ & $E$ & $\mathrm{~F}$ & G & $\mathrm{H}$ & 1 & $\mathrm{~J}$ & $\mathrm{~K}$ & $\mathrm{~L}$ & $M$ \\
\hline DG51 & 1 & far. & 3.143 & & & C & D & $E$ & $\mathrm{~F}$ & G & $\mathrm{H}$ & I & $\mathrm{J}$ & $\mathrm{K}$ & $\mathrm{L}$ & $M$ \\
\hline DG129 & 3 & mesa & 3.110 & & & C & $\mathrm{D}$ & $E$ & $\mathrm{~F}$ & G & $\mathrm{H}$ & I & $\mathrm{J}$ & $\mathrm{K}$ & $\mathrm{L}$ & $M$ \\
\hline DG121 & 2 & far. & 3.053 & & & C & D & $\mathrm{E}$ & $\mathrm{F}$ & G & $\mathrm{H}$ & I & $\mathrm{J}$ & $\mathrm{K}$ & $\mathrm{L}$ & $M$ \\
\hline DG114 & 2 & far. & 2,863 & & & & D & E & $\mathrm{F}$ & G & $\mathrm{H}$ & I & $\mathrm{J}$ & $\mathrm{K}$ & $\mathrm{L}$ & $M$ \\
\hline DG134 & 3 & mesa & 2.760 & & & & D & $E$ & $\mathrm{~F}$ & G & $\mathrm{H}$ & I & $\mathrm{J}$ & $\mathrm{K}$ & $\mathrm{L}$ & $M$ \\
\hline DG49 & 1 & far. & 2,743 & & & & D & $E$ & $\mathrm{~F}$ & G & $\mathrm{H}$ & I & $\mathrm{J}$ & $\mathrm{K}$ & L & $M$ \\
\hline DG56 & 1 & far. & 2,690 & & & & D & $E$ & $\mathrm{~F}$ & G & $\mathrm{H}$ & I & $\mathrm{J}$ & $\mathrm{K}$ & $\mathrm{L}$ & $M$ \\
\hline DG70 & 1 & far. & 2,687 & & & & $\mathrm{D}$ & $E$ & $\mathrm{~F}$ & G & $\mathrm{H}$ & I & $\mathrm{J}$ & $\mathrm{K}$ & $\mathrm{L}$ & $M$ \\
\hline DG45 & 1 & mesa & 2,627 & & & & D & $\mathrm{E}$ & $\mathrm{F}$ & G & $\mathrm{H}$ & I & $\mathrm{J}$ & $\mathrm{K}$ & $\mathrm{L}$ & $\mathrm{M}$ \\
\hline DG138 & 2 & far. & 2,613 & & & & D & $\mathrm{E}$ & $\mathrm{F}$ & G & $\mathrm{H}$ & I & $\mathrm{J}$ & $\mathrm{K}$ & $\mathrm{L}$ & $M$ \\
\hline DG133 & 3 & mesa & 2,577 & & & & D & $E$ & $\mathrm{~F}$ & G & $\mathrm{H}$ & I & $\mathrm{J}$ & $\mathrm{K}$ & $\mathrm{L}$ & $M$ \\
\hline DG115 & 2 & far. & 2,540 & & & & D & $E$ & $\mathrm{~F}$ & G & $\mathrm{H}$ & 1 & $\mathrm{~J}$ & $\mathrm{~K}$ & L & $M$ \\
\hline DG119 & 2 & far. & 2.527 & & & & D & $E$ & $\mathrm{~F}$ & G & $\mathrm{H}$ & I & $\mathrm{J}$ & $\mathrm{K}$ & $\mathrm{L}$ & $M$ \\
\hline DG124 & 2 & far. & 2,503 & & & & D & $\mathrm{E}$ & $\mathrm{F}$ & G & $\mathrm{H}$ & I & $\mathrm{J}$ & $\mathrm{K}$ & $\mathrm{L}$ & $M$ \\
\hline DG123 & 2 & far. & 2,350 & & & & & $\mathrm{E}$ & $\mathrm{F}$ & G & $\mathrm{H}$ & I & $\mathrm{J}$ & $\mathrm{K}$ & $\mathrm{L}$ & $M$ \\
\hline DG112 & 2 & far. & 2,317 & & & & & $E$ & $\mathrm{~F}$ & G & $\mathrm{H}$ & I & $\mathrm{J}$ & $\mathrm{K}$ & $\mathrm{L}$ & $M$ \\
\hline DG125 & 2 & far. & 2.250 & & & & & & $\mathrm{~F}$ & G & $\mathrm{H}$ & I & $\mathrm{J}$ & $\mathrm{K}$ & L & $M$ \\
\hline DG59 & 1 & far. & 2,180 & & & & & & & G & $\mathrm{H}$ & I & $\mathrm{J}$ & $\mathrm{K}$ & L & $M$ \\
\hline DG42 & 1 & far. & 2,160 & & & & & & & & $\mathrm{H}$ & I & $\mathrm{J}$ & $\mathrm{K}$ & $\mathrm{L}$ & $M$ \\
\hline DG60 & 1 & far. & 2,143 & & & & & & & & $\mathrm{H}$ & I & $\mathrm{J}$ & $\mathrm{K}$ & $\mathrm{L}$ & $M$ \\
\hline DG65 & 1 & far. & 2.050 & & & & & & & & $\mathrm{H}$ & I & $\mathrm{J}$ & $\mathrm{K}$ & $\mathrm{L}$ & $M$ \\
\hline DG111 & 2 & far. & 1,980 & & & & & & & & & I & $\mathrm{J}$ & $\mathrm{K}$ & $\mathrm{L}$ & $M$ \\
\hline DG62 & 1 & far. & 1,850 & & & & & & & & & I & $\mathrm{J}$ & $\mathrm{K}$ & $\mathrm{L}$ & $M$ \\
\hline DG50 & 1 & far. & 1.723 & & & & & & & & & & $\mathrm{~J}$ & $\mathrm{~K}$ & $\mathrm{~L}$ & $M$ \\
\hline DG117 & 2 & far. & 1,723 & & & & & & & & & & $\mathrm{~J}$ & $\mathrm{~K}$ & $\mathrm{~L}$ & $\mathrm{M}$ \\
\hline DG113 & 2 & far. & 1,647 & & & & & & & & & & $\mathrm{~J}$ & $\mathrm{~K}$ & $\mathrm{~L}$ & $\mathrm{M}$ \\
\hline DG130 & 3 & mesa & 1.637 & & & & & & & & & & $\mathrm{~J}$ & $\mathrm{~K}$ & L & $\mathrm{M}$ \\
\hline DG120 & 2 & far. & 1,583 & & & & & & & & & & $\mathrm{~J}$ & $\mathrm{~K}$ & L & M \\
\hline DG69 & 1 & far. & 1.503 & & & & & & & & & & $\mathrm{~J}$ & $\mathrm{~K}$ & $\mathrm{~L}$ & M \\
\hline DG52 & 1 & far. & 1,360 & & & & & & & & & & & $\mathrm{~K}$ & L & $\mathrm{M}$ \\
\hline MANT & IAC & mesa & 1.320 & & & & & & & & & & & $\mathrm{~K}$ & $\mathrm{~L}$ & $\mathrm{M}$ \\
\hline DG58 & 1 & far. & 1,233 & & & & & & & & & & & & $\mathrm{~L}$ & $\mathrm{M}$ \\
\hline DG132 & 3 & mesa & 1,163 & & & & & & & & & & & & & $\mathrm{M}$ \\
\hline DG68 & 1 & far. & 1,157 & & & & & & & & & & & & & $M$ \\
\hline DG131 & 3 & mesa & 1,150 & & & & & & & & & & & & & $\mathrm{M}$ \\
\hline DG127 & 3 & far. & 1.150 & & & & & & & & & & & & & $M$ \\
\hline DG118 & 2 & far. & 0.973 & & & & & & & & & & & & & $\mathrm{M}$ \\
\hline DG61 & 1 & far. & 0,913 & & & & & & & & & & & & & $\mathrm{M}$ \\
\hline
\end{tabular}

Região 1: Rio Negro - Bacia Amazònica 
Tabela 28 . Teste de Tukey a $\mathbf{5} \%$ de probabilidade, variável 38 teor de umidade na entrecasca das raízes. em porcentagem, $\Delta_{5 \%}=14,070$.

\begin{tabular}{|c|c|c|c|c|}
\hline Etnov. & Região & Média & $\bar{A}$ & B \\
\hline DG45 & 1 & 69,790 & A & \\
\hline DG56 & I & 68.710 & A & B \\
\hline DG73 & 1 & 68,130 & A & B \\
\hline MANT & IAC & 66.497 & A & B \\
\hline DG117 & 2 & 65,893 & A & B \\
\hline DGI15 & 2 & 65,777 & A & B \\
\hline DG67 & 1 & 65,593 & A & B \\
\hline DG118 & 2 & 65.227 & A & B \\
\hline DG62 & 1 & 65,140 & A & B \\
\hline DG69 & 1 & 64.903 & A & B \\
\hline DG123 & 2 & 64.460 & A & B \\
\hline DGS4 & 1 & 64.283 & A & B \\
\hline DG5S & 1 & 64.163 & A & B \\
\hline DG65 & 1 & 64.157 & A & B \\
\hline DG38 & 1 & 64,020 & A & B \\
\hline DG134 & 3 & 63.720 & A & B \\
\hline DG126 & 3 & 63,697 & A & B \\
\hline DG71 & 1 & 63,520 & A & B \\
\hline DG48 & 1 & 63,243 & A & B \\
\hline DG114 & 2 & 62,993 & A & B \\
\hline DG132 & 3 & 62,917 & A & B \\
\hline DG68 & 1 & 62,877 & A & B \\
\hline DG129 & 3 & 62,423 & A & B \\
\hline DG120 & 2 & 62.407 & A & B \\
\hline DG128 & 3 & 62,083 & A & B \\
\hline DG127 & 3 & 62,040 & A & B \\
\hline DG130 & 3 & 61,973 & A & B \\
\hline DG58 & 1 & 61.853 & A & B \\
\hline DG39 & 1 & 61,407 & A & B \\
\hline DG133 & 3 & 61,067 & A & B \\
\hline DG131 & 3 & 61,043 & A & B \\
\hline DG49 & 1 & 60,950 & A & B \\
\hline DG46 & 1 & 60,567 & A & B \\
\hline DG47 & 1 & 60.240 & A & B \\
\hline DG119 & 2 & 60,220 & A & B \\
\hline DG125 & 2 & 60.170 & A & B \\
\hline DG59 & 1 & 59,863 & A & B \\
\hline DG116 & 2 & 59,843 & A & B \\
\hline DG113 & 2 & 59,600 & A & B \\
\hline DG61 & 1 & 59,273 & A & B \\
\hline DG121 & 2 & 58,447 & A & B \\
\hline DG51 & 1 & 58,433 & A & B \\
\hline DG112 & 2 & 58,413 & A & B \\
\hline DG52 & 1 & 58,067 & A & B \\
\hline DG124 & 2 & 57,647 & A & B \\
\hline DG44 & 1 & 57,590 & A & B \\
\hline DG42 & 1 & 57,103 & A & B \\
\hline DG43 & 1 & 56.577 & A & B \\
\hline DG41 & 1 & 56.163 & A & B \\
\hline DGI11 & 2 & 55,990 & A & B \\
\hline DG122 & 2 & 55,943 & A & B \\
\hline DG138 & 2 & 55.797 & A & B \\
\hline DG40 & 1 & 55,760 & A & B \\
\hline DG50 & 1 & 55.620 & & B \\
\hline DG70 & 1 & 55.490 & & B \\
\hline DG60 & 1 & 55.377 & & B \\
\hline
\end{tabular}

Região 1: Rio Negro - Bacia Amazònica

Região 2: Rio Solimões - Bacia Amazònica

Região 3: Litoral Sul - SP 
Tabela 29. Teste de Tukey a 5\% de probabilidade, variável 39 teor de umidade na polpa das raizes, em porcentagem, $\Delta_{5 \%}=12,142$.

\begin{tabular}{|c|c|c|c|c|c|c|c|c|c|c|c|}
\hline Etnov. & Região & Média & A & $\mathrm{B}$ & $\mathrm{C}$ & $\mathrm{D}$ & $E$ & $\mathrm{~F}$ & $G$ & $\mathrm{H}$ & I \\
\hline DG71 & 1 & 75,29 & A & & & & & & & & \\
\hline DG54 & 1 & 72,77 & A & B & & & & & & & \\
\hline DG49 & 1 & 71,92 & A & B & C & & & & & & \\
\hline DG58 & 1 & 71,71 & A & B & C & D & & & & & \\
\hline DG138 & 2 & 69,79 & $A$ & B & $\mathrm{C}$ & $\mathrm{D}$ & E & & & & \\
\hline DG114 & 2 & 68,96 & A & B & $\mathrm{C}$ & $\mathrm{D}$ & $\mathrm{E}$ & $\mathrm{F}$ & & & \\
\hline DG62 & 1 & 67,74 & A & B & $\mathrm{C}$ & $\mathrm{D}$ & $\mathrm{E}$ & $\mathrm{F}$ & G & & \\
\hline DG46 & 1 & 67,59 & A & B & $\mathrm{C}$ & $\mathrm{D}$ & $\mathrm{E}$ & $\mathrm{F}$ & G & & \\
\hline DG59 & 1 & 66.06 & A & B & $\mathrm{C}$ & $\mathrm{D}$ & $\mathrm{E}$ & $\mathrm{F}$ & $\mathrm{G}$ & $\mathrm{H}$ & \\
\hline DG120 & 2 & 65,71 & $A$ & B & C & $\mathrm{D}$ & E & $\mathrm{F}$ & G & $\mathrm{H}$ & \\
\hline DG112 & 2 & 65.66 & A & B & $\mathrm{C}$ & $\mathrm{D}$ & $\mathrm{E}$ & $\mathrm{F}$ & G & $\mathrm{H}$ & \\
\hline DG47 & 1 & 65.38 & $A$ & B & $\mathrm{C}$ & $\mathrm{D}$ & $\mathrm{E}$ & $\mathrm{F}$ & G & $\mathrm{H}$ & \\
\hline DG60 & 1 & 65.12 & $A$ & B & C & $\mathrm{D}$ & $\mathrm{E}$ & $\mathrm{F}$ & G & $\mathrm{H}$ & \\
\hline DG73 & 1 & 65,11 & A & B & C & $\mathrm{D}$ & E & $\mathrm{F}$ & G & $\mathrm{H}$ & \\
\hline DG69 & 1 & 65,03 & A & B & C & D & $\mathrm{E}$ & $\mathrm{F}$ & G & II & \\
\hline DG50 & 1 & 64,91 & $A$ & B & $\mathrm{C}$ & $\mathrm{D}$ & E & $\mathrm{F}$ & G & $\mathrm{H}$ & \\
\hline DG55 & $i$ & 63,68 & $A$ & B & C & $\mathrm{D}$ & $\mathrm{E}$ & $\mathrm{F}$ & G & $\mathrm{H}$ & \\
\hline DG52 & 1 & 62,80 & & B & C & $\mathrm{D}$ & E & $\mathrm{F}$ & G & $\mathrm{H}$ & 1 \\
\hline DG115 & 2 & 62,70 & & B & $\mathrm{C}$ & $\mathrm{D}$ & E & $\mathrm{F}$ & G & $\mathrm{H}$ & I \\
\hline DG48 & 1 & 62.64 & & B & $\mathrm{C}$ & $\mathrm{D}$ & $\mathrm{E}$ & $\mathrm{F}$ & G & $\mathrm{H}$ & I \\
\hline DG44 & 1 & 62.59 & & B & $\mathrm{C}$ & $\mathrm{D}$ & $\mathrm{E}$ & $\mathrm{F}$ & $\mathrm{G}$ & $\mathrm{H}$ & I \\
\hline DG56 & 1 & 62,58 & & B & $\mathrm{C}$ & D & $\mathrm{E}$ & $\mathrm{F}$ & G & $\mathrm{H}$ & I \\
\hline DG121 & 2 & 62,28 & & B & $\mathrm{C}$ & D & E & $\mathrm{F}$ & G & $\mathrm{H}$ & I \\
\hline DG123 & 2 & 62,28 & & B & C & $\mathrm{D}$ & $\mathrm{E}$ & $\mathrm{F}$ & G & $\mathrm{H}$ & I \\
\hline MANT & IAC & 62,19 & & B & C & $\mathrm{D}$ & $\mathrm{E}$ & $\mathrm{F}$ & G & $\mathrm{H}$ & I \\
\hline DG45 & 1 & 61,55 & & B & C & $\mathrm{D}$ & $\mathrm{E}$ & $\mathrm{F}$ & G & $\mathrm{H}$ & I \\
\hline DG125 & 2 & 61,37 & & B & $\mathrm{C}$ & $\mathrm{D}$ & $\mathrm{E}$ & $\mathrm{F}$ & G & $\mathrm{H}$ & 1 \\
\hline DG133 & 3 & 61,08 & & B & $\mathrm{C}$ & $\mathrm{D}$ & $\mathrm{E}$ & $\mathrm{F}$ & G & $\mathrm{H}$ & I \\
\hline DG116 & 2 & 61.03 & & B & $\mathrm{C}$ & D & $\mathrm{E}$ & $\mathrm{F}$ & G & $\mathrm{H}$ & I \\
\hline DG129 & 3 & 60,99 & & B & C & D & E & $\mathrm{F}$ & G & $\mathrm{H}$ & I \\
\hline DG41 & 1 & 60,89 & & B & C & $\mathrm{D}$ & $\mathrm{E}$ & $\mathrm{F}$ & G & $\mathrm{H}$ & I \\
\hline DG51 & 1 & 60,57 & & & C & D & $\mathrm{E}$ & $\mathrm{F}$ & G & $\mathrm{H}$ & I \\
\hline DG122 & 2 & 60,18 & & & $\mathrm{C}$ & $\mathrm{D}$ & $\mathrm{E}$ & $\mathrm{F}$ & G & $\mathrm{H}$ & I \\
\hline DG70 & 1 & 59,97 & & & C & D & $\mathrm{E}$ & $\mathrm{F}$ & G & $\mathrm{H}$ & I \\
\hline DG111 & 2 & 59,78 & & & C & D & $\mathrm{E}$ & $\mathrm{F}$ & G & $\mathrm{H}$ & I \\
\hline DG40 & 1 & 59,59 & & & & D & $\mathrm{E}$ & $\mathrm{F}$ & G & $\mathrm{H}$ & I \\
\hline DG68 & 1 & 59,48 & & & & & $\mathrm{E}$ & $\mathrm{F}$ & G & $\mathrm{H}$ & I \\
\hline DG42 & 1 & 59,28 & & & & & $\mathrm{E}$ & $\mathrm{F}$ & G & $\mathrm{H}$ & I \\
\hline DG117 & 2 & 59.07 & & & & & $\mathrm{E}$ & $\mathrm{F}$ & G & $\mathrm{H}$ & I \\
\hline DG67 & 1 & 58,90 & & & & & $\mathrm{E}$ & $\mathrm{F}$ & G & $\mathrm{H}$ & I \\
\hline DG65 & 1 & 58.39 & & & & & $\mathrm{E}$ & $\mathrm{F}$ & G & $\mathrm{H}$ & I \\
\hline DG43 & 1 & 57,69 & & & & & $\mathrm{E}$ & $\mathrm{F}$ & G & $\mathrm{H}$ & I \\
\hline DG127 & 3 & 57,50 & & & & & & $\mathrm{~F}$ & $G$ & $\mathrm{H}$ & I \\
\hline DG134 & 3 & 56,80 & & & & & & & G & $\mathrm{H}$ & I \\
\hline DG119 & 2 & 56.77 & & & & & & & G & $\mathrm{H}$ & I \\
\hline DG113 & 2 & 56,69 & & & & & & & G & $\mathrm{H}$ & I \\
\hline DG61 & 1 & 56,66 & & & & & & & $\mathrm{G}$ & $\mathrm{H}$ & I \\
\hline DG39 & 1 & 56,50 & & & & & & & G & $\mathrm{H}$ & I \\
\hline DG126 & 3 & 56,48 & & & & & & & G & $\mathrm{H}$ & I \\
\hline DG38 & 1 & 56,41 & & & & & & & G & $\mathrm{H}$ & I \\
\hline DG132 & 3 & 55,34 & & & & & & & & $\mathrm{H}$ & I \\
\hline DG131 & 3 & 55,30 & & & & & & & & $\mathrm{H}$ & I \\
\hline DG130 & 3 & 55.22 & & & & & & & & $\mathrm{H}$ & I \\
\hline DG118 & 2 & 54,68 & & & & & & & & $\mathrm{H}$ & I \\
\hline DG128 & 3 & 54,59 & & & & & & & & $\mathrm{H}$ & I \\
\hline DG124 & 2 & 51,48 & & & & & & & & & I \\
\hline
\end{tabular}

Região 1: Rio Negro - Bacia Amazònica 
Tabela 30. Teste de Tukey a 5\% de probabilidade, variável 40 porcentagem de proteína nas raizes. na base seca, $\Delta_{5 \%}=0,3157$.

\begin{tabular}{|c|c|c|c|c|c|c|c|c|c|c|c|c|c|c|c|c|c|c|c|c|c|c|c|c|c|}
\hline Etnov. & Reg. & Média & A & $\mathrm{B}$ & $C$ & $\mathrm{D}$ & $\mathrm{E}$ & $F$ & $G$ & $\mathrm{H}$ & $I$ & $\mathrm{~J}$ & $\mathrm{~K}$ & $\mathrm{~L}$ & $M$ & $\mathrm{~N}$ & $\mathrm{O}$ & $P$ & $\mathrm{Q}$ & $\mathrm{R}$ & $\mathrm{s}$ & $\mathrm{T}$ & $\mathrm{U}$ & V & $w$ \\
\hline DG71 & 1 & 5.3067 & $\mathrm{~A}$ & & & & & & & & & & & & & & & & & & & & & & \\
\hline DG122 & 2 & 4,1700 & & B & & & & & & & & & & & & & & & & & & & & & \\
\hline DG46 & 1 & 4.1233 & & B & & & & & & & & & & & & & & & & & & & & & \\
\hline DG73 & 1 & 3,7900 & & & C & & & & & & & & & & & & & & & & & & & & \\
\hline DG131 & 3 & 3,6333 & & & $\mathrm{C}$ & D & & & & & & & & & & & & & & & & & & & \\
\hline DG70 & 1 & 3,6100 & & & C & D & & & & & & & & & & & & & & & & & & & \\
\hline DG128 & 3 & 3,5533 & & & $\mathrm{C}$ & $\mathrm{D}$ & & & & & & & & & & & & & & & & & & & \\
\hline DG54 & 1 & 3,5133 & & & C & D & & & & & & & & & & & & & & & & & & & \\
\hline DG127 & 3 & 3.4567 & & & & D & $\mathrm{E}$ & & & & & & & & & & & & & & & & & & \\
\hline DG115 & 2 & 3.3900 & & & & D & $E$ & $F$ & & & & & & & & & & & & & & & & & \\
\hline DG55 & 1 & 3,1933 & & & & & $\mathrm{E}$ & $\mathrm{F}$ & G & & & & & & & & & & & & & & & & \\
\hline DG116 & 2 & 3.1400 & & & & & & $\mathrm{~F}$ & G & H & & & & & & & & & & & & & & & \\
\hline DG113 & 2 & 3.1267 & & & & & & $\mathrm{~F}$ & G & $\mathrm{H}$ & I & & & & & & & & & & & & & & \\
\hline DG60 & 1 & 3.0667 & & & & & & & $G$ & $\mathrm{H}$ & 1 & $J$ & & & & & & & & & & & & & \\
\hline DG129 & 3 & 2,8967 & & & & & & & G & $\mathrm{H}$ & I & $\mathrm{J}$ & $\mathrm{K}$ & & & & & & & & & & & & \\
\hline DG123 & 2 & 2,8767 & & & & & & & & $\mathrm{H}$ & I & $\mathrm{J}$ & $\mathrm{K}$ & & & & & & & & & & & & \\
\hline DG126 & 3 & 2,8633 & & & & & & & & $\mathrm{H}$ & I & $\mathrm{J}$ & $\mathrm{K}$ & & & & & & & & & & & & \\
\hline DG119 & 2 & 2.8500 & & & & & & & & $\mathrm{H}$ & I & $\mathrm{J}$ & $\mathrm{K}$ & L & & & & & & & & & & & \\
\hline DG48 & 1 & 2,8467 & & & & & & & & $\mathrm{H}$ & I & $\mathrm{J}$ & $\mathrm{K}$ & $\mathrm{L}$ & & & & & & & & & & & \\
\hline DG138 & 2 & 2,8267 & & & & & & & & $\mathrm{H}$ & I & $\mathrm{J}$ & $\mathrm{K}$ & L & $\mathrm{M}$ & & & & & & & & & & \\
\hline DG59 & 1 & 2,8233 & & & & & & & & & I & $J$ & $\mathrm{~K}$ & $\mathrm{~L}$ & M & & & & & & & & & & \\
\hline DG117 & 2 & 2.8100 & & & & & & & & & & $\mathrm{~J}$ & $\mathrm{~K}$ & $\mathrm{~L}$ & $\mathrm{M}$ & & & & & & & & & & \\
\hline DG52 & 1 & 2,7100 & & & & & & & & & & & $\mathrm{~K}$ & $\mathrm{~L}$ & $M$ & $\mathrm{~N}$ & & & & & & & & & \\
\hline DG44 & 1 & 2.6200 & & & & & & & & & & & $\mathrm{~K}$ & $\mathrm{~L}$ & $\mathrm{M}$ & $\mathrm{N}$ & $\mathrm{O}$ & & & & & & & & \\
\hline DG49 & 1 & 2,6133 & & & & & & & & & & & $\mathrm{~K}$ & $\mathrm{~L}$ & $M$ & $\mathrm{~N}$ & $\mathrm{O}$ & & & & & & & & \\
\hline DG132 & 3 & 2.5433 & & & & & & & & & & & & $\mathrm{~L}$ & $\mathrm{M}$ & $\mathrm{N}$ & $\mathrm{O}$ & $\mathrm{P}$ & & & & & & & \\
\hline DG50 & 1 & 2,5267 & & & & & & & & & & & & & $\mathrm{M}$ & $\mathrm{N}$ & $\mathrm{O}$ & $\mathrm{P}$ & & & & & & & \\
\hline DG38 & $i$ & 2,4767 & & & & & & & & & & & & & & $\mathrm{~N}$ & $\mathrm{O}$ & $P$ & Q & & & & & & \\
\hline DG134 & 3 & 2,4600 & & & & & & & & & & & & & & $\mathrm{~N}$ & $\mathrm{O}$ & $P$ & $\mathrm{Q}$ & $\mathrm{R}$ & & & & & \\
\hline DG51 & 1 & 2.4267 & & & & & & & & & & & & & & $\mathrm{~N}$ & $\mathrm{O}$ & $P$ & $Q$ & $\mathrm{R}$ & S & & & & \\
\hline DG69 & 1 & 2,4033 & & & & & & & & & & & & & & $\mathrm{~N}$ & $\mathrm{O}$ & $P$ & Q & $\mathrm{R}$ & $S$ & & & & \\
\hline DG42 & 1 & 2.3933 & & & & & & & & & & & & & & & $\mathrm{O}$ & $P$ & $\mathrm{Q}$ & $\mathrm{R}$ & $S$ & & & & \\
\hline DG65 & 1 & 2.3800 & & & & & & & & & & & & & & & $\mathrm{O}$ & $P$ & $\mathrm{Q}$ & $\mathrm{R}$ & $S$ & & & & \\
\hline DG124 & 2 & 2.3700 & & & & & & & & & & & & & & & $\mathrm{O}$ & $P$ & $\mathrm{Q}$ & $\mathrm{R}$ & $S$ & & & & \\
\hline DG125 & 2 & 2,3600 & & & & & & & & & & & & & & & $\mathrm{O}$ & $\mathrm{P}$ & $\mathrm{Q}$ & $\mathrm{R}$ & $S$ & & & & \\
\hline DG130 & 3 & 2,3267 & & & & & & & & & & & & & & & $\mathrm{O}$ & $\mathrm{P}$ & $\mathrm{Q}$ & $\mathrm{R}$ & $S$ & & & & \\
\hline DG68 & 1 & 2,3133 & & & & & & & & & & & & & & & $\mathrm{O}$ & $P$ & $\mathrm{Q}$ & $\mathrm{R}$ & $S$ & & & & \\
\hline DG41 & 1 & 2.3100 & & & & & & & & & & & & & & & $\mathrm{O}$ & $\mathrm{P}$ & Q & $\mathrm{R}$ & $S$ & & & & \\
\hline DG40 & 1 & 2,2700 & & & & & & & & & & & & & & & & $\mathrm{P}$ & Q & $\mathrm{R}$ & $S$ & $\mathrm{~T}$ & & & \\
\hline DG47 & 1 & 2.2567 & & & & & & & & & & & & & & & & $P$ & $\mathrm{Q}$ & $\mathrm{R}$ & $S$ & $\mathrm{~T}$ & & & \\
\hline DG45 & 1 & 2,2533 & & & & & & & & & & & & & & & & $P$ & $Q$ & $\mathrm{R}$ & $S$ & $\mathrm{~T}$ & & & \\
\hline DG111 & 2 & 2.2500 & & & & & & & & & & & & & & & & $\mathrm{P}$ & $\mathrm{Q}$ & $\mathrm{R}$ & $S$ & $\mathrm{~T}$ & & & \\
\hline DG114 & 2 & 2,1667 & & & & & & & & & & & & & & & & & $\mathrm{Q}$ & $\mathrm{R}$ & $S$ & $\mathrm{~T}$ & $\mathrm{U}$ & & \\
\hline DG121 & 2 & 2.1633 & & & & & & & & & & & & & & & & & $\mathrm{Q}$ & $\mathrm{R}$ & $S$ & $\mathrm{~T}$ & $\mathrm{U}$ & & \\
\hline DG133 & 3 & 2.1600 & & & & & & & & & & & & & & & & & & $\mathrm{R}$ & $S$ & $\mathrm{~T}$ & $\mathrm{U}$ & & \\
\hline DG43 & 1 & 2.1267 & & & & & & & & & & & & & & & & & & & $\mathrm{~S}$ & $\mathrm{~T}$ & $\mathrm{U}$ & & \\
\hline DG58 & 1 & 1,9733 & & & & & & & & & & & & & & & & & & & & $\mathrm{~T}$ & $\mathrm{U}$ & $v$ & \\
\hline DG39 & 1 & 1,9567 & & & & & & & & & & & & & & & & & & & & $\mathrm{~T}$ & $\mathrm{U}$ & $V$ & \\
\hline DG62 & 1 & 1.8700 & & & & & & & & & & & & & & & & & & & & & $\mathrm{U}$ & V & \\
\hline DG112 & 2 & 1.8533 & & & & & & & & & & & & & & & & & & & & & $\mathrm{U}$ & V & \\
\hline DG67 & 1 & 1.7733 & & & & & & & & & & & & & & & & & & & & & & $v$ & \\
\hline DG120 & 2 & 1,7367 & & & & & & & & & & & & & & & & & & & & & & $V$ & \\
\hline DG56 & 1 & 1,6800 & & & & & & & & & & & & & & & & & & & & & & V & \\
\hline DG1 18 & 2 & 1.3133 & & & & & & & & & & & & & & & & & & & & & & & W \\
\hline MANT & IAC & 1,3133 & & & & & & & & & & & & & & & & & & & & & & & W \\
\hline DG61 & 1 & 1,2600 & & & & & & & & & & & & & & & & & & & & & & & W \\
\hline
\end{tabular}

Região 1: Rio Negro - Bacia Amazònica Região 2: Rio Solimões - Bacia Amazònica Região 3: Litoral 5ul - SP 
Tabela 31 . Teste de Tukey a $5 \%$ de probabilidade, variável 41 porcentagem de amido nas raizes, na base seca, $\Delta_{5 \%}=0,7884$.

\begin{tabular}{|c|c|c|c|c|c|c|c|c|c|c|c|c|c|c|c|c|c|c|c|c|c|c|c|c|c|c|c|c|c|c|}
\hline Etnov & Rg & Med & $\mathrm{A}$ & B & $\mathrm{C}$ & $\mathrm{D}$ & $E$ & $\mathrm{~F}$ & $G$ & $\mathrm{H}$ & I & $\mathrm{J}$ & $\mathrm{K}$ & $\mathrm{L}$ & $\mathrm{M}$ & $\mathrm{N}$ & $\mathrm{O}$ & $P$ & $\mathrm{Q}$ & $\mathrm{R}$ & $\mathrm{S}$ & $\mathrm{T}$ & $U$ & $\mathrm{~V}$ & $W$ & $x$ & $\bar{Y}$ & $Z$ & $\mathrm{~A}$ & $\bar{B}$ \\
\hline DG67 & 1 & 90,640 & A & & & & & & & & & & & & & & & & & & & & & & & & & & & \\
\hline DG118 & 2 & 90,357 & A & B & & & & & & & & & & & & & & & & & & & & & & & & & & \\
\hline DG132 & 3 & 90.280 & A & B & & & & & & & & & & & & & & & & & & & & & & & & & & \\
\hline DG65 & 1 & 90,003 & A & B & C & & & & & & & & & & & & & & & & & & & & & & & & & \\
\hline DG130 & 3 & 89,850 & & B & C & D & & & & & & & & & & & & & & & & & & & & & & & & \\
\hline DG111 & 2 & 89,647 & & B & C & D & E & & & & & & & & & & & & & & & & & & & & & & & \\
\hline DG39 & 1 & 89,640 & & B & C & D & E & $\mathrm{F}$ & & & & & & & & & & & & & & & & & & & & & & \\
\hline DG134 & 3 & 89,627 & & B & $\mathrm{C}$ & D & E & $F$ & & & & & & & & & & & & & & & & & & & & & & \\
\hline DG61 & 1 & 89,483 & & & C & D & E & $\mathrm{F}$ & G & & & & & & & & & & & & & & & & & & & & & \\
\hline DG38 & 1 & 89,447 & & & C & D & E & $\mathrm{F}$ & $G$ & $\mathrm{H}$ & & & & & & & & & & & & & & & & & & & & \\
\hline MANT & IA & 89,400 & & & $\mathrm{C}$ & D & $\mathrm{E}$ & $\mathrm{F}$ & G & $\mathrm{H}$ & I & & & & & & & & & & & & & & & & & & & \\
\hline DG112 & 2 & 89,270 & & & $\mathrm{C}$ & D & $\mathrm{E}$ & $\mathrm{F}$ & G & $\mathrm{H}$ & i & $J$ & & & & & & & & & & & & & & & & & & \\
\hline DG131 & 3 & 89,240 & & & $\mathrm{C}$ & D & E & $\mathrm{F}$ & $\mathrm{G}$ & $\mathrm{H}$ & 1 & $\mathrm{~J}$ & $\mathrm{~K}$ & & & & & & & & & & & & & & & & & \\
\hline DG124 & 2 & 89.237 & & & C & D & E & $\mathrm{F}$ & G & $\mathrm{H}$ & 1 & $\mathrm{~J}$ & $\mathrm{~K}$ & & & & & & & & & & & & & & & & & \\
\hline DG47 & 1 & 89.130 & & & & D & $\mathrm{E}$ & $\mathrm{F}$ & G & $\mathrm{H}$ & I & $\mathrm{J}$ & $\mathrm{K}$ & L & & & & & & & & & & & & & & & & \\
\hline DG56 & 1 & 89,053 & & & & & $\mathrm{E}$ & $\mathrm{F}$ & $G$ & $\mathrm{H}$ & 1 & $\mathrm{~J}$ & $\mathrm{~K}$ & $\mathrm{~L}$ & & & & & & & & & & & & & & & & \\
\hline DG119 & 2 & 88,927 & & & & & $\mathrm{E}$ & $\mathrm{F}$ & G & $\mathrm{H}$ & I & $\mathrm{J}$ & $\mathrm{K}$ & $\mathrm{L}$ & M & & & & & & & & & & & & & & & \\
\hline DG127 & 3 & 88,907 & & & & & E & $\mathrm{F}$ & G & $\mathrm{H}$ & I & $\mathrm{J}$ & $\mathrm{K}$ & $\mathrm{L}$ & $M$ & & & & & & & & & & & & & & & \\
\hline DG133 & 3 & 88.857 & & & & & & $\mathrm{~F}$ & G & $\mathrm{H}$ & 1 & $\mathrm{~J}$ & $\mathrm{~K}$ & $\mathrm{~L}$ & $M$ & $N$ & & & & & & & & & & & & & & \\
\hline DG42 & 1 & 88,810 & & & & & & & $G$ & $\mathrm{H}$ & I & $\mathrm{J}$ & $\mathrm{K}$ & $\mathrm{L}$ & $\mathrm{M}$ & $\mathrm{N}$ & & & & & & & & & & & & & & \\
\hline DG120 & 2 & 88,810 & & & & & & & $G$ & $\mathrm{H}$ & I & $\mathrm{J}$ & $\mathrm{K}$ & $\mathrm{L}$ & $\mathrm{M}$ & $N$ & & & & & & & & & & & & & & \\
\hline DG43 & 1 & 88,803 & & & & & & & $\mathrm{G}$ & $\mathrm{H}$ & I & $\mathrm{J}$ & $\mathrm{K}$ & $\mathrm{L}$ & $\mathrm{M}$ & $\mathrm{N}$ & & & & & & & & & & & & & & \\
\hline DG117 & 2 & 88,670 & & & & & & & & $\mathrm{H}$ & I & $\mathrm{J}$ & $\mathrm{K}$ & $\mathrm{L}$ & $M$ & $N$ & $\mathrm{O}$ & & & & & & & & & & & & & \\
\hline DG44 & 1 & 88,617 & & & & & & & & & 1 & $\mathrm{~J}$ & $\mathrm{~K}$ & $\mathrm{~L}$ & $M$ & $N$ & $\mathrm{O}$ & $\mathrm{P}$ & & & & & & & & & & & & \\
\hline DG40 & 1 & 88,537 & & & & & & & & & & $\mathrm{~J}$ & $\mathrm{~K}$ & $\mathrm{~L}$ & $\mathrm{M}$ & $\mathrm{N}$ & $\mathrm{O}$ & $P$ & & & & & & & & & & & & \\
\hline DG62 & 1 & 88,457 & & & & & & & & & & & $\mathrm{~K}$ & $\mathrm{~L}$ & $M$ & $\mathrm{~N}$ & $\mathrm{O}$ & P & & & & & & & & & & & & \\
\hline DG128 & 3 & 88,457 & & & & & & & & & & & $\mathrm{~K}$ & $\mathrm{~L}$ & $M$ & $\mathrm{~N}$ & $\mathrm{O}$ & $P$ & & & & & & & & & & & & \\
\hline DG129 & 3 & 88,437 & & & & & & & & & & & & $\mathrm{~L}$ & $M$ & $\mathrm{~N}$ & $\mathrm{O}$ & $\mathrm{P}$ & $\mathrm{Q}$ & & & & & & & & & & & \\
\hline DG41 & 1 & 88,413 & & & & & & & & & & & & $\mathrm{~L}$ & $M$ & $\mathrm{~N}$ & $\mathrm{O}$ & $\mathrm{P}$ & $\mathrm{Q}$ & & & & & & & & & & & \\
\hline DG50 & 1 & 88,393 & & & & & & & & & & & & $\mathrm{~L}$ & $M$ & $\mathrm{~N}$ & $\mathrm{O}$ & $P$ & $\mathrm{Q}$ & & & & & & & & & & & \\
\hline DG52 & 1 & 88,383 & & & & & & & & & & & & $\mathrm{~L}$ & $M$ & $\mathrm{~N}$ & $\mathrm{O}$ & $\mathrm{P}$ & $\mathrm{Q}$ & & & & & & & & & & & \\
\hline DG113 & 2 & 88,343 & & & & & & & & & & & & L & $\mathrm{M}$ & $\mathrm{N}$ & $\mathrm{O}$ & $P$ & $\mathrm{Q}$ & & & & & & & & & & & \\
\hline DG45 & 1 & 88,343 & & & & & & & & & & & & $\mathrm{~L}$ & M & $\mathrm{N}$ & $\mathrm{O}$ & $\mathrm{P}$ & Q & & & & & & & & & & & \\
\hline DG68 & 1 & 88,253 & & & & & & & & & & & & & $M$ & $N$ & $\mathrm{O}$ & $P$ & $\mathrm{Q}$ & $\mathrm{R}$ & & & & & & & & & & \\
\hline DG116 & 2 & 88,200 & & & & & & & & & & & & & $M$ & $N$ & $\mathrm{O}$ & $P$ & $\mathrm{Q}$ & $\mathrm{R}$ & & & & & & & & & & \\
\hline DG51 & 1 & 88,197 & & & & & & & & & & & & & $M$ & $N$ & $\mathrm{O}$ & $P$ & $\mathrm{Q}$ & $\mathrm{R}$ & & & & & & & & & & \\
\hline DG126 & 3 & 88,147 & & & & & & & & & & & & & M & $N$ & $\mathrm{O}$ & $\mathrm{P}$ & Q & $\mathrm{R}$ & $S$ & & & & & & & & & \\
\hline DG125 & 2 & 88,103 & & & & & & & & & & & & & & $\mathrm{~N}$ & $\mathrm{O}$ & $P$ & $\mathrm{Q}$ & $\mathrm{R}$ & $\mathrm{S}$ & & & & & & & & & \\
\hline DG121 & 2 & 88,010 & & & & & & & & & & & & & & & $\mathrm{O}$ & $\mathrm{P}$ & $\mathrm{Q}$ & $\mathrm{R}$ & $S$ & $\mathrm{~T}$ & & & & & & & & \\
\hline DG69 & 1 & 87,833 & & & & & & & & & & & & & & & & $P$ & $\mathrm{Q}$ & $\mathrm{R}$ & $S$ & $\mathrm{~T}$ & $\mathrm{U}$ & & & & & & & \\
\hline DG122 & 2 & 87,650 & & & & & & & & & & & & & & & & & $\mathrm{Q}$ & $\mathrm{R}$ & $S$ & $\mathrm{~T}$ & $\mathrm{U}$ & V & & & & & & \\
\hline DG123 & 2 & 87,497 & & & & & & & & & & & & & & & & & & $\mathrm{R}$ & $\mathrm{S}$ & $T$ & $\mathrm{U}$ & V & & & & & & \\
\hline DG58 & 1 & 87,467 & & & & & & & & & & & & & & & & & & $\mathrm{R}$ & $S$ & $\mathrm{~T}$ & $\mathrm{U}$ & $\mathrm{V}$ & & & & & & \\
\hline DGl14 & 2 & 87,383 & & & & & & & & & & & & & & & & & & & $\mathrm{~S}$ & $\mathrm{~T}$ & $\mathrm{U}$ & V & & & & & & \\
\hline DG70 & I & 87,310 & & & & & & & & & & & & & & & & & & & & $\mathrm{~T}$ & $\mathrm{U}$ & V & & & & & & \\
\hline DG59 & 1 & 87,283 & & & & & & & & & & & & & & & & & & & & $\mathrm{~T}$ & $\mathrm{U}$ & V & & & & & & \\
\hline DG48 & 1 & 87,063 & & & & & & & & & & & & & & & & & & & & & $\mathrm{U}$ & V & W & & & & & \\
\hline DG60 & 1 & 86,977 & & & & & & & & & & & & & & & & & & & & & & V & W & & & & & \\
\hline DG49 & 1 & 86,923 & & & & & & & & & & & & & & & & & & & & & & V & W & $x$ & & & & \\
\hline DG55 & I & 86.430 & & & & & & & & & & & & & & & & & & & & & & & $w$ & $x$ & $\mathrm{Y}$ & & & \\
\hline DG138 & 2 & 86,177 & & & & & & & & & & & & & & & & & & & & & & & & $X$ & $Y$ & & & \\
\hline DG115 & 2 & 85,687 & & & & & & & & & & & & & & & & & & & & & & & & & $\mathrm{Y}$ & Z & & \\
\hline DG73 & 1 & 84,910 & & & & & & & & & & & & & & & & & & & & & & & & & & Z & A & \\
\hline DG54 & 1 & 84,907 & & & & & & & & & & & & & & & & & & & & & & & & & & Z & A & \\
\hline DG46 & 1 & 84.577 & & & & & & & & & & & & & & & & & & & & & & & & & & & A & \\
\hline DG71 & 1 & 79,430 & & & & & & & & & & & & & & & & & & & & & & & & & & & & B \\
\hline
\end{tabular}


Tabela 32. Teste de Tukey a 5\% de probabilidade, variável 42 porcentagem de matéria graxa nas raizes. na base seca, $\Delta_{\varsigma \%}=0,2128$.

\begin{tabular}{|c|c|c|c|c|c|c|c|c|c|c|}
\hline Etnov. & Reg. & Média & $\mathrm{A}$ & $\mathrm{B}$ & $\mathrm{C}$ & $\mathrm{D}$ & $E$ & $\mathrm{~F}$ & $\mathrm{G}$ & $\mathrm{H}$ \\
\hline DG130 & 3 & 0.9933 & A & & & & & & & \\
\hline DG124 & 2 & 0,9833 & A & B & & & & & & \\
\hline DG38 & 1 & 0,9633 & A & B & C & & & & & \\
\hline DG48 & 1 & 0,9433 & A & B & C & D & & & & \\
\hline DG129 & 3 & 0,9433 & A & B & C & D & & & & \\
\hline DG60 & 1 & 0,9400 & A & B & C & D & E & & & \\
\hline DG131 & 3 & 0,9333 & A & B & $\mathrm{C}$ & D & $E$ & & & \\
\hline DG138 & 2 & 0,9200 & A & B & C & $\mathrm{D}$ & $E$ & $\mathrm{~F}$ & & \\
\hline DG115 & 2 & 0,9200 & A & B & $\mathrm{C}$ & $\mathrm{D}$ & $E$ & $\mathrm{~F}$ & & \\
\hline DG45 & 1 & 0,9167 & A & B & $\mathrm{C}$ & D & $E$ & $\mathrm{~F}$ & & \\
\hline DG62 & 1 & 0.9167 & A & B & C & D & E & $\mathrm{F}$ & & \\
\hline DG44 & 1 & 0,9100 & A & B & $\mathrm{C}$ & D & $E$ & $\mathrm{~F}$ & & \\
\hline DG73 & 1 & 0,9067 & A & B & C & D & $E$ & $\mathrm{~F}$ & & \\
\hline DG125 & 2 & 0,9067 & A & B & C & D & $E$ & $\mathrm{~F}$ & & \\
\hline DG111 & 2 & 0.9067 & A & B & $\mathrm{C}$ & $\mathrm{D}$ & E & $\mathrm{F}$ & & \\
\hline DG123 & 2 & 0,9033 & A & B & C & D & E & $\mathrm{F}$ & & \\
\hline DG61 & 1 & 0,8967 & A & B & C & D & E & $\mathrm{F}$ & G & \\
\hline DG120 & 2 & 0,8967 & A & B & C & D & $E$ & $\mathrm{~F}$ & G & \\
\hline DG122 & 2 & 0.8800 & A & B & $\mathrm{C}$ & D & $E$ & $\mathrm{~F}$ & G & \\
\hline DG128 & 3 & 0,8767 & A & B & $\mathrm{C}$ & D & $E$ & $\mathrm{~F}$ & G & \\
\hline DG47 & 1 & 0,8767 & A & B & C & D & $E$ & $\mathrm{~F}$ & G & \\
\hline DG51 & 1 & 0,8767 & A & B & C & D & E & $\mathrm{F}$ & G & \\
\hline DG41 & I & 0,8733 & A & B & C & $\mathrm{D}$ & $E$ & $\mathrm{~F}$ & G & \\
\hline DG126 & 3 & 0,8700 & A & B & C & D & $E$ & $\mathrm{~F}$ & G & \\
\hline DG71 & 1 & 0.8600 & A & B & $\mathrm{C}$ & $\mathrm{D}$ & $E$ & $\mathrm{~F}$ & G & $\mathrm{H}$ \\
\hline DG55 & 1 & 0,8567 & A & B & $\mathrm{C}$ & $\mathrm{D}$ & $E$ & $\mathrm{~F}$ & G & $\mathrm{H}$ \\
\hline DG119 & 2 & 0.8567 & A & B & C & D & E & $\mathrm{F}$ & G & $\mathrm{H}$ \\
\hline DG43 & 1 & 0,8567 & A & B & C & D & $\mathrm{E}$ & $\mathrm{F}$ & G & $\mathrm{H}$ \\
\hline DG39 & 1 & 0,8533 & A & B & C & D & $E$ & $\mathrm{~F}$ & G & $\mathrm{H}$ \\
\hline DG68 & 1 & 0,8533 & A & B & $\mathrm{C}$ & D & $E$ & $\mathrm{~F}$ & G & $\mathrm{H}$ \\
\hline DG121 & 2 & 0.8433 & A & B & $\mathrm{C}$ & D & $E$ & $\mathrm{~F}$ & G & $\mathrm{H}$ \\
\hline DG116 & 2 & 0,8400 & A & B & $\mathrm{C}$ & D & $E$ & $\mathrm{~F}$ & G & $\mathrm{H}$ \\
\hline DG133 & 3 & 0,8333 & A & B & $\mathrm{C}$ & D & $E$ & $\mathrm{~F}$ & G & $\mathrm{H}$ \\
\hline DG40 & 1 & 0,8267 & A & B & $\mathrm{C}$ & D & $E$ & $\mathrm{~F}$ & G & $\mathrm{H}$ \\
\hline DG59 & 1 & 0,8200 & A & B & C & D & $E$ & $\mathrm{~F}$ & G & $\mathrm{H}$ \\
\hline DG65 & 1 & 0,8200 & A & B & C & D & $\mathrm{E}$ & $\mathrm{F}$ & G & $\mathrm{H}$ \\
\hline DG69 & 1 & 0,8200 & A & B & $\mathrm{C}$ & D & $E$ & $\mathrm{~F}$ & G & $\mathrm{H}$ \\
\hline DG132 & 3 & 0,8167 & A & B & $\mathrm{C}$ & $\mathrm{D}$ & $E$ & $\mathrm{~F}$ & G & $\mathrm{H}$ \\
\hline DG70 & 1 & 0,8167 & A & B & C & D & E & $\mathrm{F}$ & G & $\mathrm{H}$ \\
\hline DG56 & 1 & 0,8067 & A & B & C & D & $E$ & $\mathrm{~F}$ & G & $\mathrm{H}$ \\
\hline DG67 & 1 & 0,8033 & A & B & $\mathrm{C}$ & D & $E$ & $\mathrm{~F}$ & G & $\mathrm{H}$ \\
\hline DG54 & 1 & 0,8000 & A & B & $\mathrm{C}$ & D & $E$ & $\mathrm{~F}$ & G & $\mathrm{H}$ \\
\hline DG117 & 2 & 0.7967 & A & B & $\mathrm{C}$ & $\mathrm{D}$ & $E$ & $\mathrm{~F}$ & G & $\mathrm{H}$ \\
\hline DG127 & 3 & 0,7933 & A & B & $\mathrm{C}$ & D & $E$ & $\mathrm{~F}$ & G & $\mathrm{H}$ \\
\hline DG118 & 2 & 0,7900 & A & B & $\mathrm{C}$ & D & $E$ & $\mathrm{~F}$ & G & $\mathrm{H}$ \\
\hline DG49 & 1 & 0,7800 & & B & $\mathrm{C}$ & $\mathrm{D}$ & $E$ & $\mathrm{~F}$ & G & $\mathrm{H}$ \\
\hline MANT & IAC & 0.7767 & & B & C & D & $E$ & $\mathrm{~F}$ & G & $\mathrm{H}$ \\
\hline DG46 & 1 & 0,7667 & & & $\mathrm{C}$ & $\mathrm{D}$ & $E$ & $\mathrm{~F}$ & G & $\mathrm{H}$ \\
\hline DG112 & 2 & 0,7500 & & & & $\mathrm{D}$ & $E$ & $\mathrm{~F}$ & G & $\mathrm{H}$ \\
\hline DG42 & 1 & 0,7400 & & & & D & $E$ & $\mathrm{~F}$ & G & $\mathrm{H}$ \\
\hline DG52 & 1 & 0.7300 & & & & & E & $\mathrm{F}$ & G & $\mathrm{H}$ \\
\hline DG113 & 2 & 0,7200 & & & & & & $\mathrm{~F}$ & G & $\mathrm{H}$ \\
\hline DG50 & 1 & 0,7200 & & & & & & $\mathrm{~F}$ & G & $\mathrm{H}$ \\
\hline DG58 & 1 & 0,7200 & & & & & & $\mathrm{~F}$ & G & $\mathrm{H}$ \\
\hline DG134 & 3 & 0.6900 & & & & & & & G & $\mathrm{H}$ \\
\hline DG114 & 2 & 0.6567 & & & & & & & & $\mathrm{H}$ \\
\hline
\end{tabular}

Região 1: Rio Negro - Bacia Amazònica

Região 2: Rio Solimões - Bacia Amazònica

Região 3: Litoral Sul - SP 
Tabela 33. Teste de Tukey a 5\% de probabilidade, variável 43 porcentagem de cinzas nas raizes. na base seca, $\Delta_{9 \%}=0,3605$.

\begin{tabular}{|c|c|c|c|c|c|c|c|c|c|c|c|c|c|c|c|c|c|c|c|c|c|c|c|c|c|c|c|c|c|c|}
\hline Etnov & $\mathrm{R}$ & Med & $A$ & B & $\mathrm{C}$ & $\mathrm{D}$ & $E$ & $F$ & G & $\mathrm{H}$ & I & $\mathrm{J}$ & $\mathrm{K}$ & $\mathrm{L}$ & $M$ & $\mathrm{~N}$ & $\mathrm{O}$ & $P$ & $\mathrm{Q}$ & $\mathrm{R}$ & $S$ & $\mathrm{~T}$ & $\mathrm{U}$ & $\mathrm{V}$ & W & $\mathrm{X}$ & $Y$ & $Z$ & $A$ & $\bar{B}$ \\
\hline DG71 & 1 & 4.7333 & A & & & & & & & & & & & & & & & & & & & & & & & & & & & \\
\hline DG73 & 1 & 3.7633 & & B & & & & & & & & & & & & & & & & & & & & & & & & & & \\
\hline DG54 & 1. & 3.5867 & & B & & & & & & & & & & & & & & & & & & & & & & & & & & \\
\hline DG5s & 1 & 3,4267 & & B & & & & & & & & & & & & & & & & & & & & & & & & & & \\
\hline DG46 & 1 & 3,0533 & & & C & & & & & & & & & & & & & & & & & & & & & & & & & \\
\hline DG41 & 1 & 3,0133 & & & C & D & & & & & & & & & & & & & & & & & & & & & & & & \\
\hline DG138 & 2 & 2.8533 & & & C & D & $E$ & & & & & & & & & & & & & & & & & & & & & & & \\
\hline DG40 & 1 & 2,7967 & & & C & D & $\mathrm{E}$ & $\mathrm{F}$ & & & & & & & & & & & & & & & & & & & & & & \\
\hline DG38 & 1 & 2,6967 & & & C & D & $\mathrm{E}$ & $\mathrm{F}$ & G & & & & & & & & & & & & & & & & & & & & & \\
\hline DG129 & 3 & 2.6700 & & & & D & $\mathrm{E}$ & $\mathrm{F}$ & G & $\mathrm{H}$ & & & & & & & & & & & & & & & & & & & & \\
\hline DG60 & 1 & 2,6033 & & & & & $\mathrm{E}$ & $\mathrm{F}$ & G & $\mathrm{H}$ & I & & & & & & & & & & & & & & & & & & & \\
\hline DG48 & 1 & 2,5867 & & & & & $\mathrm{E}$ & $\mathrm{F}$ & G & $\mathrm{H}$ & 1 & $\mathrm{~J}$ & & & & & & & & & & & & & & & & & & \\
\hline DG115 & 2 & 2.5767 & & & & & $\mathrm{E}$ & $\mathrm{F}$ & G & $\mathrm{H}$ & I & $\mathrm{J}$ & & & & & & & & & & & & & & & & & & \\
\hline DG58 & 1 & 2,5400 & & & & & $\mathrm{E}$ & $\mathrm{F}$ & G & $\mathrm{H}$ & I & $\mathrm{J}$ & $\mathrm{K}$ & & & & & & & & & & & & & & & & & \\
\hline DG114 & 2 & 2.5267 & & & & & $\mathrm{E}$ & $\mathrm{F}$ & G & $\mathrm{H}$ & 1 & $J$ & $\mathrm{~K}$ & $\mathrm{~L}$ & & & & & & & & & & & & & & & & \\
\hline DG49 & 1 & 2,5167 & & & & & $\mathrm{E}$ & $\mathrm{F}$ & G & $\mathrm{H}$ & I & $\mathrm{J}$ & $\mathrm{K}$ & $\mathrm{L}$ & $\mathrm{M}$ & & & & & & & & & & & & & & & \\
\hline DG70 & 1 & 2,4767 & & & & & & $\mathrm{~F}$ & G & $\mathrm{H}$ & I & $\mathrm{J}$ & $\mathrm{K}$ & $\mathrm{L}$ & $\mathrm{M}$ & $N$ & & & & & & & & & & & & & & \\
\hline DG69 & 1 & 2,4567 & & & & & & $\mathrm{~F}$ & G & $\mathrm{H}$ & I & $\mathrm{J}$ & $\mathrm{K}$ & $\mathrm{L}$ & $\mathrm{M}$ & $\mathrm{N}$ & $\mathrm{O}$ & & & & & & & & & & & & & \\
\hline DG123 & 2 & 2.4533 & & & & & & $\mathrm{~F}$ & G & $\mathrm{H}$ & I & $\mathrm{J}$ & $\mathrm{K}$ & L & $\mathrm{M}$ & $\mathrm{N}$ & $\mathrm{O}$ & $\mathrm{P}$ & & & & & & & & & & & & \\
\hline DG117 & 2 & 2,4267 & & & & & & & G & $\mathrm{H}$ & I & $\mathrm{J}$ & $\mathrm{K}$ & $\mathrm{L}$ & M & $\mathrm{N}$ & $\mathrm{O}$ & $P$ & Q & & & & & & & & & & & \\
\hline DG125 & 2 & 2,4000 & & & & & & & G & $\mathrm{H}$ & I & $\mathrm{J}$ & $\mathrm{K}$ & L & M & $\mathrm{N}$ & $\mathrm{O}$ & $P$ & Q & $\mathrm{R}$ & & & & & & & & & & \\
\hline DG65 & 1 & 2,3967 & & & & & & & G & $\mathrm{H}$ & I & $\mathrm{J}$ & $\mathrm{K}$ & L & M & $\mathrm{N}$ & $\mathrm{O}$ & $P$ & Q & $\mathrm{R}$ & & & & & & & & & & \\
\hline DG59 & 1 & 2,3933 & & & & & & & G & $\mathrm{H}$ & I & $\mathrm{J}$ & $\mathrm{K}$ & L & M & $\mathrm{N}$ & $\mathrm{O}$ & P & Q & $\mathrm{R}$ & $S$ & & & & & & & & & \\
\hline DG134 & 3 & 2,3367 & & & & & & & G & $\mathrm{H}$ & 1 & $\mathrm{~J}$ & $\mathrm{~K}$ & L & M & $\mathrm{N}$ & $\mathrm{O}$ & $P$ & Q & $\mathrm{R}$ & $S$ & $\mathrm{~T}$ & & & & & & & & \\
\hline DG133 & 3 & 2,3300 & & & & & & & & $\mathrm{H}$ & I & $J$ & $\mathrm{~K}$ & $\mathrm{~L}$ & M & $\mathrm{N}$ & $\mathrm{O}$ & $\mathrm{P}$ & Q & $\mathrm{R}$ & $S$ & $\mathrm{~T}$ & $\mathrm{U}$ & & & & & & & \\
\hline DG47 & 1 & 2,3133 & & & & & & & & $\mathrm{H}$ & I & $\mathrm{J}$ & $\mathrm{K}$ & L & $M$ & $\mathrm{~N}$ & $\mathrm{O}$ & $P$ & Q & $\mathrm{R}$ & $S$ & $\mathrm{~T}$ & $\mathrm{U}$ & & & & & & & \\
\hline DG128 & 3 & 2,2833 & & & & & & & & & I & $\mathrm{J}$ & $\mathrm{K}$ & $\mathrm{L}$ & M & $\mathrm{N}$ & $\mathrm{O}$ & $P$ & Q & $\mathrm{R}$ & $S$ & $T$ & $\mathrm{U}$ & V & & & & & & \\
\hline DG50 & 1 & 2,2533 & & & & & & & & & I & $\mathrm{J}$ & $\mathrm{K}$ & L & M & $\mathrm{N}$ & $\mathrm{O}$ & $\mathrm{P}$ & $\mathrm{Q}$ & $\mathrm{R}$ & S & $\mathrm{T}$ & U & V & W & & & & & \\
\hline DG56 & 1 & 2,2300 & & & & & & & & & & $\mathrm{~J}$ & $\mathrm{~K}$ & $\mathrm{~L}$ & $\mathrm{M}$ & $\mathrm{N}$ & $\mathrm{O}$ & $P$ & Q & $\mathrm{R}$ & $S$ & $\mathrm{~T}$ & $\mathrm{U}$ & V & W & & & & & \\
\hline DG122 & 2 & 2,2300 & & & & & & & & & & $\mathrm{~J}$ & $\mathrm{~K}$ & $\mathrm{~L}$ & $M$ & $N$ & $\mathrm{O}$ & $\mathrm{P}$ & Q & $\mathrm{R}$ & $S$ & $T$ & $\mathrm{U}$ & V & W & & & & & \\
\hline DG44 & 1 & 2,2300 & & & & & & & & & & $\mathrm{~J}$ & $\mathrm{~K}$ & $\mathrm{~L}$ & M & $\mathrm{N}$ & $\mathrm{O}$ & $\mathrm{P}$ & Q & $\mathrm{R}$ & $S$ & $T$ & $\mathrm{U}$ & $\mathrm{V}$ & $w$ & & & & & \\
\hline DG62 & 1 & 2.2300 & & & & & & & & & & $\mathrm{~J}$ & $\mathrm{~K}$ & $\mathrm{~L}$ & M & $N$ & $\mathrm{O}$ & $\mathrm{P}$ & Q & R & S & $T$ & $\mathrm{U}$ & V & W & & & & & \\
\hline DG119 & 2 & 2.2267 & & & & & & & & & & $\mathrm{~J}$ & K & $\mathrm{L}$ & M & $N$ & $\mathrm{O}$ & $\mathrm{P}$ & Q & $\mathrm{R}$ & $S$ & $\mathrm{~T}$ & U & V & W & & & & & \\
\hline DG68 & 1 & 2,2000 & & & & & & & & & & & $\mathrm{~K}$ & $\mathrm{~L}$ & M & $\mathrm{N}$ & $\mathrm{O}$ & $\mathrm{P}$ & Q & $\begin{array}{l}\mathrm{R} \\
\mathrm{R}\end{array}$ & $\begin{array}{l}S \\
S\end{array}$ & $\begin{array}{l}\mathrm{T} \\
\mathrm{T}\end{array}$ & $\begin{array}{l}\mathrm{U} \\
\mathrm{U}\end{array}$ & V & $\begin{array}{l}\text { W } \\
W\end{array}$ & & & & & \\
\hline MANT & IA & 2.1967 & & & & & & & & & & & K & $\mathrm{L}$ & M & $\mathrm{N}$ & $\mathrm{O}$ & $P$ & $\begin{array}{l}\mathrm{Q} \\
\mathrm{Q}\end{array}$ & $\begin{array}{l}\mathrm{R} \\
\mathrm{R}\end{array}$ & $\mathrm{S}$ & $\begin{array}{l}1 \\
T\end{array}$ & U & $\begin{array}{l}\mathrm{V} \\
\mathrm{V}\end{array}$ & $\begin{array}{l}\text { W } \\
W\end{array}$ & & & & & \\
\hline DG132 & 3 & 2,1700 & & & & & & & & & & & & $\mathrm{~L}$ & M & $\mathrm{N}$ & $\mathrm{O}$ & P & $\begin{array}{l}\mathrm{Q} \\
\mathrm{Q}\end{array}$ & $\begin{array}{l}\mathrm{R} \\
\mathrm{R}\end{array}$ & $S$ & $\mathrm{~T}$ & $\mathrm{U}$ & $\mathrm{V}$ & W & & & & & \\
\hline DG51 & 1 & 2,1667 & & & & & & & & & & & & $\mathrm{~L}$ & M & $\mathrm{N}$ & $\mathrm{O}$ & P & $\begin{array}{l}\mathrm{Q} \\
\mathrm{Q}\end{array}$ & $\mathrm{R}$ & $S$ & $\mathrm{~T}$ & $\mathrm{U}$ & V & W & & & & & \\
\hline DG52 & 1 & 2,1600 & & & & & & & & & & & & & M & $\mathrm{N}$ & $\mathrm{O}$ & $P$ & $\begin{array}{l}\mathrm{Q} \\
\mathrm{Q}\end{array}$ & $\mathrm{R}$ & $S$ & $\mathrm{~T}$ & $\mathrm{U}$ & V & W & $\mathrm{X}$ & & & & \\
\hline DG121 & 2 & 2,1367 & & & & & & & & & & & & & & $N$ & $\mathrm{O}$ & $P$ & $\begin{array}{l}\mathrm{Q} \\
\mathrm{Q}\end{array}$ & $\mathrm{R}$ & $S$ & $\mathrm{~T}$ & $\mathrm{U}$ & V & W & $\mathrm{X}$ & Y & & & \\
\hline DG120 & 2 & 2,1100 & & & & & & & & & & & & & & & $\mathrm{O}$ & $P$ & $\begin{array}{l}\mathrm{Q} \\
\mathrm{Q}\end{array}$ & $\mathrm{R}$ & $S$ & $\mathrm{~T}$ & $\mathrm{U}$ & V & W & $\mathrm{X}$ & $Y$ & Z & & \\
\hline DG124 & 2 & $\begin{array}{l}2,0933 \\
2,0900\end{array}$ & & & & & & & & & & & & & & & & $\mathrm{P}$ & $\begin{array}{l}\mathrm{Q} \\
\mathrm{Q}\end{array}$ & $\mathrm{R}$ & $S$ & $\mathrm{~T}$ & $\mathrm{U}$ & V & W & $\mathrm{X}$ & Y & Z & & \\
\hline $\begin{array}{l}\text { DG42 } \\
\text { DG39 }\end{array}$ & $\begin{array}{l}1 \\
1\end{array}$ & $\begin{array}{l}2,0900 \\
2,0600\end{array}$ & & & & & & & & & & & & & & & & & & $R$ & $S$ & $\mathrm{~T}$ & $\mathrm{U}$ & $\mathrm{V}$ & W & $x$ & $\mathrm{Y}$ & Z & & \\
\hline DG45 & $\begin{array}{l}1 \\
1\end{array}$ & 2,0333 & & & & & & & & & & & & & & & & & & & $S$ & $\mathrm{~T}$ & $\mathrm{U}$ & V & W & $\mathrm{X}$ & $Y$ & Z & & \\
\hline DG43 & 1 & 2,0300 & & & & & & & & & & & & & & & & & & & & $\mathrm{~T}$ & $\mathrm{U}$ & $\mathrm{V}$ & W & $x$ & $Y$ & Z & & \\
\hline DG112 & 2 & 2,0067 & & & & & & & & & & & & & & & & & & & & $\mathrm{~T}$ & $\mathrm{U}$ & V & W & $\mathrm{X}$ & $\mathrm{Y}^{\prime}$ & Z & & \\
\hline DG113 & 2 & 1,9733 & & & & & & & & & & & & & & & & & & & & & $\mathrm{U}$ & $\mathrm{V}$ & W & $X$ & $Y$ & Z & & \\
\hline DG126 & 3 & 1,9500 & & & & & & & & & & & & & & & & & & & & & & V & $\mathrm{W}$ ? & $\mathrm{X}$ & $\mathrm{Y}$ & Z & A & \\
\hline DG118 & 2 & 1,9167 & & & & & & & & & & & & & & & & & & & & & & & $\mathrm{~W}:$ & $\mathrm{X}$ & $Y$ & $Z$ & A & \\
\hline DG61 & 1 & 1,9033 & & & & & & & & & & & & & & & & & & & & & & & $\mathrm{~W}$ ? & $\mathrm{X}$ & $Y$ & $Z$ & $\mathrm{~A}$ & \\
\hline DG127 & 3 & 1,7933 & & & & & & & & & & & & & & & & & & & & & & & & $x$ & $Y$ & $Z$ & A & \\
\hline DG131 & 3 & 1,7800 & & & & & & & & & & & & & & & & & & & & & & & & $x$ & $\mathrm{Y}$ & Z & A & \\
\hline DG116 & 2 & 1,7700 & & & & & & & & & & & & & & & & & & & & & & & & & $Y$ & $Z$ & A & \\
\hline DG67 & 1 & 1,7467 & & & & & & & & & & & & & & & & & & & & & & & & & & $Z$ & $A$ & \\
\hline DG130 & 3 & 1.6067 & & & & & & & & & & & & & & & & & & & & & & & & & & & A & B \\
\hline DG111 & 2 & 1,3267 & & & & & & & & & & & & & & & & & & & & & & & & & & & & $\mathrm{~B}$ \\
\hline
\end{tabular}


Tabela 34 . Teste de Tukey a $5 \%$ de probabilidade, variável 44 porcentagem de fibras nas raizes, na base seca, $\Delta_{5 \%}=0,3739$.

\begin{tabular}{|c|c|c|c|c|c|c|c|c|c|c|c|c|c|c|c|c|c|c|c|c|c|c|c|c|}
\hline Etnov. & Reg. & Média & $\bar{A}$ & $\mathrm{~B}$ & $\bar{C}$ & $\mathrm{D}$ & $E$ & $F$ & $\mathrm{G}$ & $\mathrm{H}$ & I & $\mathrm{J}$ & $\mathrm{K}$ & $\mathrm{L}$ & $\bar{M}$ & $N$ & $\mathrm{O}$ & $P$ & $\begin{array}{ll}\mathrm{Q} & \mathrm{R}\end{array}$ & $\begin{array}{ll}\mathrm{R} & \mathrm{S}\end{array}$ & $\bar{T}$ & $\mathrm{U}$ & $\mathrm{V}$ & $\bar{W}$ \\
\hline DG71 & 1 & 7,6967 & A & & & & & & & & & & & & & & & & & & & & & \\
\hline DG46 & 1 & 5.5433 & & B & & & & & & & & & & & & & & & & & & & & \\
\hline DG115 & 2 & 5,4733 & & B & C & & & & & & & & & & & & & & & & & & & \\
\hline DG58 & 1 & 5,2100 & & B & $\mathrm{C}$ & $\mathrm{D}$ & & & & & & & & & & & & & & & & & & \\
\hline DG54 & 1 & 5,1667 & & & C & D & E & & & & & & & & & & & & & & & & & \\
\hline DG138 & 2 & 5.1233 & & & C & D & E & & & & & & & & & & & & & & & & & \\
\hline DG60 & 1 & 4.8533 & & & & D & $\mathrm{E}$ & $\mathrm{F}$ & & & & & & & & & & & & & & & & \\
\hline DG121 & 2 & 4.8067 & & & & & $\mathrm{E}$ & $\mathrm{F}$ & G & & & & & & & & & & & & & & & \\
\hline DG59 & 1 & 4.7967 & & & & & E & $\mathrm{F}$ & G & & & & & & & & & & & & & & & \\
\hline DG49 & 1 & 4.7000 & & & & & & $\mathrm{~F}$ & G & $\mathrm{H}$ & & & & & & & & & & & & & & \\
\hline DG114 & 2 & 4.6667 & & & & & & $\mathrm{~F}$ & G & $\mathrm{H}$ & I & & & & & & & & & & & & & \\
\hline DG51 & 1 & 4.6400 & & & & & & $\mathrm{~F}$ & G & $\mathrm{H}$ & I & $J$ & & & & & & & & & & & & \\
\hline DG73 & 1 & 4,6400 & & & & & & $\mathrm{~F}$ & G & $\mathrm{H}$ & I & $\mathrm{J}$ & & & & & & & & & & & & \\
\hline DG48 & 1 & 4.6333 & & & & & & $\mathrm{~F}$ & G & $\mathrm{H}$ & I & $\mathrm{J}$ & & & & & & & & & & & & \\
\hline DG61 & 1 & 4.5600 & & & & & & $\mathrm{~F}$ & G & $\mathrm{H}$ & I & $\mathrm{J}$ & $\mathrm{K}$ & & & & & & & & & & & \\
\hline DG112 & 2 & 4,4700 & & & & & & & G & $\mathrm{H}$ & I & $\mathrm{J}$ & $\mathrm{K}$ & L & & & & & & & & & & \\
\hline DG56 & 1 & 4.4667 & & & & & & & G & $\mathrm{H}$ & I & $\mathrm{J}$ & $\mathrm{K}$ & $\mathrm{L}$ & & & & & & & & & & \\
\hline DG68 & 1 & 4,4200 & & & & & & & & $\mathrm{H}$ & I & $\mathrm{J}$ & $\mathrm{K}$ & $\mathrm{L}$ & & & & & & & & & & \\
\hline DG126 & 3 & 4,3900 & & & & & & & & $\mathrm{H}$ & I & $\mathrm{J}$ & $\mathrm{K}$ & $\mathrm{L}$ & & & & & & & & & & \\
\hline MANT & IAC & 4.3700 & & & & & & & & $\mathrm{H}$ & I & $\mathrm{J}$ & $\mathrm{K}$ & $\mathrm{L}$ & & & & & & & & & & \\
\hline DG125 & 2 & 4,3033 & & & & & & & & & I & $\mathrm{J}$ & $\mathrm{K}$ & $\mathrm{L}$ & & & & & & & & & & \\
\hline DG43 & 1 & 4.2867 & & & & & & & & & & $J$ & $\mathrm{~K}$ & $\mathrm{~L}$ & & & & & & & & & & \\
\hline DG123 & 2 & 4.2533 & & & & & & & & & & & $\mathrm{~K}$ & L & & & & & & & & & & \\
\hline DG50 & 1 & 4.2500 & & & & & & & & & & & $\mathrm{~K}$ & $\mathrm{~L}$ & & & & & & & & & & \\
\hline DG133 & 3 & 4,2033 & & & & & & & & & & & K & $\mathrm{L}$ & M & & & & & & & & & \\
\hline DG116 & 2 & 4,1933 & & & & & & & & & & & $\mathrm{~K}$ & $\mathrm{~L}$ & $\mathrm{M}$ & & & & & & & & & \\
\hline DG69 & 1 & 4.1667 & & & & & & & & & & & & $\mathrm{~L}$ & $\mathrm{M}$ & $\mathrm{N}$ & & & & & & & & \\
\hline DG120 & 2 & 4.1667 & & & & & & & & & & & & $\mathrm{~L}$ & $\mathrm{M}$ & $N$ & & & & & & & & \\
\hline DG40 & 1 & 4,1467 & & & & & & & & & & & & $\mathrm{~L}$ & $\mathrm{M}$ & $\mathrm{N}$ & & & & & & & & \\
\hline DG45 & $i$ & 4.1300 & & & & & & & & & & & & $\mathrm{~L}$ & $\mathrm{M}$ & $\mathrm{N}$ & & & & & & & & \\
\hline DG113 & 2 & 4.1233 & & & & & & & & & & & & $\mathrm{~L}$ & $\mathrm{M}$ & $N$ & & & & & & & & \\
\hline DG55 & 1 & 4.1233 & & & & & & & & & & & & $\mathrm{~L}$ & $\mathrm{M}$ & $\mathrm{N}$ & & & & & & & & \\
\hline DG52 & 1 & 4,1133 & & & & & & & & & & & & L & $\mathrm{M}$ & $\mathrm{N}$ & & & & & & & & \\
\hline DG70 & 1 & 3.8667 & & & & & & & & & & & & & $\mathrm{M}$ & $N$ & $\mathrm{O}$ & & & & & & & \\
\hline DG111 & 2 & 3.8100 & & & & & & & & & & & & & & $\mathrm{~N}$ & $\mathrm{O}$ & & & & & & & \\
\hline DG42 & 1 & 3.8100 & & & & & & & & & & & & & & $\mathrm{~N}$ & O & & & & & & & \\
\hline DG134 & 3 & 3,8067 & & & & & & & & & & & & & & $\mathrm{~N}$ & $\mathrm{O}$ & & & & & & & \\
\hline DG41 & 1 & 3.7333 & & & & & & & & & & & & & & & O & $P$ & & & & & & \\
\hline DG39 & 1 & 3,6367 & & & & & & & & & & & & & & & O & $P$ & & & & & & \\
\hline DG44 & 1 & 3.6267 & & & & & & & & & & & & & & & $\mathrm{O}$ & $P$ & & & & & & \\
\hline DG62 & 1 & 3,6033 & & & & & & & & & & & & & & & O & $\mathrm{P}$ & Q & & & & & \\
\hline DG47 & 1 & 3.5433 & & & & & & & & & & & & & & & O & $\mathrm{P}$ & Q & $\mathrm{R}$ & & & & \\
\hline DG124 & 2 & 3,5067 & & & & & & & & & & & & & & & $\mathrm{O}$ & $\mathrm{P}$ & $\mathrm{Q}$ & $S$ & & & & \\
\hline DG117 & 2 & 3.4300 & & & & & & & & & & & & & & & & P & $\mathrm{Q}$ & $S$ & $\mathrm{~T}$ & & & \\
\hline DG129 & 3 & 3,4200 & & & & & & & & & & & & & & & & $\mathrm{P}$ & $\mathrm{Q}$ & $S$ & $\mathrm{~T}$ & & & \\
\hline DG 130 & 3 & 3.2300 & & & & & & & & & & & & & & & & & $\mathrm{Q}$ & $S$ & $\mathrm{~T}$ & $\mathrm{U}$ & & \\
\hline DG122 & 2 & 3.2167 & & & & & & & & & & & & & & & & & $\mathrm{R}$ & $S$ & $\mathrm{~T}$ & U & & \\
\hline DG 119 & 2 & 3.2067 & & & & & & & & & & & & & & & & & $\mathrm{R}$ & $\mathrm{s}$ & $\mathrm{T}$ & $\mathrm{U}$ & & \\
\hline DG127 & 3 & 3,1667 & & & & & & & & & & & & & & & & & & S & $\mathrm{T}$ & $\mathrm{U}$ & & \\
\hline DG 118 & 2 & 3,1367 & & & & & & & & & & & & & & & & & & $S$ & $\mathrm{~T}$ & $\mathrm{U}$ & & \\
\hline DG67 & 1 & 3,1033 & & & & & & & & & & & & & & & & & & & $\mathrm{~T}$ & $\mathrm{U}$ & & \\
\hline DG128 & 3 & 2.9100 & & & & & & & & & & & & & & & & & & & & $\mathrm{U}$ & $\mathrm{V}$ & \\
\hline DG131 & 3 & 2,6333 & & & & & & & & & & & & & & & & & & & & & V & w \\
\hline DG65 & 1 & 2.5267 & & & & & & & & & & & & & & & & & & & & & & W \\
\hline DG38 & 1 & 2.5267 & & & & & & & & & & & & & & & & & & & & & & w \\
\hline DG132 & 3 & 2,5067 & & & & & & & & & & & & & & & & & & & & & & w \\
\hline
\end{tabular}

Região 1: Rio Negro - Bacia Amazònica

Região 2: Rio Solimões - Bacia Amazônica

Região 3: Litoral 5ul - SP 
Tabela 35. Teste de Tukey a 5\% de probabilidade, variável 45 porcentagem de açúcar solúvel nas raizes. na base seca, $\Delta_{5 \%}=0,3849$.

\begin{tabular}{|c|c|c|c|c|c|c|c|c|c|c|c|}
\hline Etnov. & Região & Média & $\overline{\mathrm{A}}$ & B & $\bar{C}$ & $\bar{D}$ & $\bar{E}$ & $\bar{F}$ & $\bar{G}$ & $\mathrm{H}$ & $\bar{I}$ \\
\hline DG138 & 2 & 1,9633 & A & & & & & & & & \\
\hline DG49 & 1 & 1,9567 & $\mathrm{~A}$ & & & & & & & & \\
\hline DG121 & 2 & 1.9233 & A & B & & & & & & & \\
\hline DG55 & 1 & 1,9200 & A & B & & & & & & & \\
\hline DG111 & 2 & 1,9067 & $\mathrm{~A}$ & B & & & & & & & \\
\hline DG125 & 2 & 1,8967 & A & B & & & & & & & \\
\hline DG46 & 1 & 1,8933 & A & B & & & & & & & \\
\hline DG68 & 1 & 1,8633 & $\mathrm{~A}$ & B & $\mathrm{C}$ & & & & & & \\
\hline DG48 & 1 & 1,8567 & A & B & $\mathrm{C}$ & & & & & & \\
\hline DG43 & 1 & 1,8433 & A & B & C & & & & & & \\
\hline DG73 & 1 & 1,8367 & A & B & $\mathrm{C}$ & & & & & & \\
\hline MANT & $\mathrm{IAC}$ & 1.8333 & i & B & $\mathrm{C}$ & & & & & & \\
\hline DG58 & 1 & 1.8300 & A & B & $\mathrm{C}$ & & & & & & \\
\hline DG38 & 1 & 1,8100 & A & B & $\mathrm{C}$ & D & & & & & \\
\hline DG115 & 2 & 1,8067 & $\mathrm{~A}$ & B & $\mathrm{C}$ & D & & & & & \\
\hline DG65 & 1 & 1,8033 & A & B & $\mathrm{C}$ & D & & & & & \\
\hline DG122 & 2 & 1,8000 & A & B & $\mathrm{C}$ & D & & & & & \\
\hline DG123 & 2 & 1,8000 & A & B & $\mathrm{C}$ & D & & & & & \\
\hline DG69 & 1 & 1,7967 & A & B & $\mathrm{C}$ & D & & & & & \\
\hline DG127 & 3 & 1,7867 & A & B & $\mathrm{C}$ & D & & & & & \\
\hline DG54 & 1 & 1,7833 & $\mathrm{~A}$ & B & $\mathrm{C}$ & D & & & & & \\
\hline DG39 & 1 & 1,7700 & A & B & $\mathrm{C}$ & D & & & & & \\
\hline DG117 & 2 & 1,7700 & A & B & C & D & & & & & \\
\hline DG47 & 1 & 1,7633 & $\mathrm{~A}$ & B & $\mathrm{C}$ & D & $\mathrm{E}$ & & & & \\
\hline DG67 & 1 & 1.7533 & A & B & $\mathrm{C}$ & D & $\mathrm{E}$ & $\mathrm{F}$ & & & \\
\hline DG59 & 1 & 1,7433 & $\mathrm{~A}$ & B & $\mathrm{C}$ & D & $\mathrm{E}$ & $\mathrm{F}$ & & & \\
\hline DG119 & 2 & 1,7433 & A & B & $\mathrm{C}$ & D & $\mathrm{E}$ & $\mathrm{F}$ & & & \\
\hline DG45 & 1 & 1,7400 & A & B & $\mathrm{C}$ & D & $\mathrm{E}$ & $\mathrm{F}$ & & & \\
\hline DG130 & 3 & 1,7333 & A & B & $\mathrm{C}$ & D & $\mathrm{E}$ & $\mathrm{F}$ & & & \\
\hline DG50 & 1 & 1,7233 & A & B & C & D & E & $\mathrm{F}$ & G & & \\
\hline DG116 & 2 & 1.7133 & $\mathrm{~A}$ & B & $\mathrm{C}$ & D & $\mathrm{E}$ & $\mathrm{F}$ & $\mathrm{G}$ & $\mathrm{H}$ & \\
\hline DG128 & 3 & 1,7133 & A & B & $\mathrm{C}$ & D & $\mathrm{E}$ & $\mathrm{F}$ & G & $\mathrm{H}$ & \\
\hline DG71 & 1 & 1,7133 & A & B & C & D & E & $\mathrm{F}$ & G & $\mathrm{H}$ & \\
\hline DG120 & 2 & 1,7133 & A & B & $\mathrm{C}$ & D & $\mathrm{E}$ & $\mathrm{F}$ & $\mathrm{G}$ & $\mathrm{H}$ & \\
\hline DG131 & 3 & 1,7133 & A & B & $\mathrm{C}$ & D & $\mathrm{E}$ & $\mathrm{F}$ & G & $\mathrm{H}$ & \\
\hline DG52 & 1 & 1,6967 & A & B & C & D & E & $\mathrm{F}$ & G & $\mathrm{H}$ & \\
\hline DG113 & 2 & 1,6833 & A & B & $\mathrm{C}$ & D & $\mathrm{E}$ & $\mathrm{F}$ & $\mathrm{G}$ & $\mathrm{H}$ & \\
\hline DG62 & 1 & 1,6700 & A & B & $\mathrm{C}$ & D & $\mathrm{E}$ & $\mathrm{F}$ & G & $\mathrm{H}$ & \\
\hline DG126 & 3 & 1,6667 & A & B & $\mathrm{C}$ & D & $\mathrm{E}$ & $\mathrm{F}$ & G & $\mathrm{H}$ & \\
\hline DG118 & 2 & 1,6333 & $\mathrm{~A}$ & B & $\mathrm{C}$ & D & $\mathrm{E}$ & $\mathrm{F}$ & $\mathrm{G}$ & $\mathrm{H}$ & \\
\hline DG51 & 1 & 1,6300 & A & B & $\mathrm{C}$ & D & $\mathrm{E}$ & $\mathrm{F}$ & G & $\mathrm{H}$ & \\
\hline DG42 & 1 & 1.6200 & A & B & $\mathrm{C}$ & D & E & $\mathrm{F}$ & G & $\mathrm{H}$ & \\
\hline DG61 & 1 & 1,6167 & A & B & $\mathrm{C}$ & D & $\mathrm{E}$ & $\mathrm{F}$ & G & $\mathrm{H}$ & \\
\hline DG41 & 1 & 1,5867 & A & B & $\mathrm{C}$ & D & $\mathrm{E}$ & $\mathrm{F}$ & G & $\mathrm{H}$ & \\
\hline DG70 & 1 & 1,5667 & & B & $\mathrm{C}$ & D & E & $\mathrm{F}$ & G & $\mathrm{H}$ & \\
\hline DG133 & 3 & 1,5633 & & B & $\mathrm{C}$ & D & $E$ & $\mathrm{~F}$ & G & $\mathrm{H}$ & \\
\hline DG112 & 2 & 1,5400 & & B & $\mathrm{C}$ & D & $\mathrm{E}$ & $\mathrm{F}$ & $\mathrm{G}$ & $\mathrm{H}$ & \\
\hline DG44 & 1 & 1,5400 & & B & $\mathrm{C}$ & D & E & $\mathrm{F}$ & G & $\mathrm{H}$ & \\
\hline DG129 & 3 & 1,4900 & & & $\mathrm{C}$ & D & E & $\mathrm{F}$ & G & $\mathrm{H}$ & I \\
\hline DG134 & 3 & 1,4433 & & & & D & $\mathrm{E}$ & $\mathrm{F}$ & G & $\mathrm{H}$ & I \\
\hline DG114 & 2 & 1,4300 & & & & D & E & $\mathrm{F}$ & G & $\mathrm{H}$ & I \\
\hline DG60 & 1 & 1,3833 & & & & & E & $\mathrm{F}$ & G & $\mathrm{H}$ & I \\
\hline DG56 & 1 & 1.3700 & & & & & & $\mathrm{~F}$ & G & $\mathrm{H}$ & I \\
\hline DG132 & 3 & 1,3400 & & & & & & & G & $\mathrm{H}$ & I \\
\hline DG40 & 1 & 1,3367 & & & & & & & & $\mathrm{H}$ & I \\
\hline DG124 & 2 & 1.1433 & & & & & & & & & I \\
\hline
\end{tabular}

Região 1: Rio Negro - Bacia Amazônica

Região 2: Rio Solimões - Bacia Amazònica Região 3: Litoral 5ul - SP 
Tabela 36. Teste de Tukey a 5\% de probabilidade, variável 46 teor de umidade nas raízes. em porcentagem, $\Delta_{5 \%}=11,858$.

\begin{tabular}{|c|c|c|c|c|c|c|c|c|c|c|}
\hline Etnov. & Região & Média & $\mathrm{A}$ & B & $\mathrm{C}$ & $\bar{D}$ & $E$ & $\mathrm{~F}$ & $\mathrm{G}$ & $\mathrm{H}$ \\
\hline DG54 & 1 & 76,133 & A & & & & & & & \\
\hline DG71 & 1 & 75,257 & A & B & & & & & & \\
\hline DG58 & 1 & 72.263 & A & B & C & & & & & \\
\hline DG138 & 2 & 70,910 & A & B & C & D & & & & \\
\hline DG114 & 2 & 69,073 & A & B & $\mathrm{C}$ & D & E & & & \\
\hline DG46 & 1 & 67,407 & A & B & C & D & E & $\mathrm{F}$ & & \\
\hline DG62 & 1 & 67,343 & A & B & C & D & E & $\mathrm{F}$ & & \\
\hline DG112 & 2 & 66.777 & A & B & C & D & E & $\mathrm{F}$ & G & \\
\hline DG49 & 1 & 66.710 & A & B & C & D & E & $\mathrm{F}$ & G & \\
\hline DG59 & 1 & 66.273 & A & B & C & D & $E$ & $\mathrm{~F}$ & G & \\
\hline DG60 & $i$ & 66,080 & A & B & $\mathrm{C}$ & D & $\mathrm{E}$ & $\mathrm{F}$ & G & \\
\hline DG120 & 2 & 65.750 & A & B & C & D & E & $\mathrm{F}$ & G & \\
\hline DG55 & 1 & 65.553 & A & B & C & D & E & $\mathrm{F}$ & G & \\
\hline DG50 & i & 65,537 & A & B & $\mathrm{C}$ & D & E & $\mathrm{F}$ & G & \\
\hline DG47 & 1 & 65,183 & A & B & C & D & E & $\mathrm{F}$ & G & $\mathrm{H}$ \\
\hline DG69 & 1 & 64,610 & A & B & C & D & E & $\mathrm{F}$ & G & $\mathrm{H}$ \\
\hline DG73 & 1 & 64,600 & A & B & $\mathrm{C}$ & D & $\mathrm{E}$ & $\mathrm{F}$ & G & $\mathrm{H}$ \\
\hline DG115 & 2 & 64.247 & & B & C & D & E & $\mathrm{F}$ & G & $\mathrm{H}$ \\
\hline DG52 & 1 & 64,110 & & B & C & D & E & $\mathrm{F}$ & G & $\mathrm{H}$ \\
\hline DG56 & 1 & 63.957 & & B & $\mathrm{C}$ & D & $\mathrm{E}$ & $\mathrm{F}$ & G & $\mathrm{H}$ \\
\hline DG48 & 1 & 63,753 & & B & C & D & $\mathrm{E}$ & $\mathrm{F}$ & G & $\mathrm{H}$ \\
\hline DG41 & 1 & 62,973 & & & C & D & E & $\mathrm{F}$ & G & $\mathrm{H}$ \\
\hline DG121 & 2 & 62,753 & & & $\mathrm{C}$ & D & E & $\mathrm{F}$ & G & $\mathrm{H}$ \\
\hline MANT & IAC & 62,587 & & & C & D & E & $\mathrm{F}$ & G & $\mathrm{H}$ \\
\hline DG45 & 1 & 62,443 & & & C & D & E & $\mathrm{F}$ & G & $\mathrm{H}$ \\
\hline DG44 & 1 & 62,390 & & & $\mathrm{C}$ & D & $\mathrm{E}$ & $\mathrm{F}$ & G & $\mathrm{H}$ \\
\hline DG125 & 2 & 62,377 & & & $\mathrm{C}$ & D & E & $\mathrm{F}$ & G & $\mathrm{H}$ \\
\hline DG133 & 3 & 62,313 & & & C & D & E & $\mathrm{F}$ & G & $\mathrm{H}$ \\
\hline DG40 & 1 & 61,983 & & & C & D & E & $\mathrm{F}$ & G & $\mathrm{H}$ \\
\hline DG51 & 1 & 61.843 & & & $\mathrm{C}$ & D & E & $\mathrm{F}$ & G & $\mathrm{H}$ \\
\hline DG116 & 2 & 61,780 & & & C & D & $\mathrm{E}$ & $\mathrm{F}$ & G & $\mathrm{H}$ \\
\hline DG123 & 2 & 61,767 & & & C & D & E & $\mathrm{F}$ & G & $\mathrm{H}$ \\
\hline DG65 & 1 & 61,363 & & & $\mathrm{C}$ & D & $\mathrm{E}$ & $\mathrm{F}$ & G & $\mathrm{H}$ \\
\hline DG122 & 2 & 60.810 & & & C & D & $\mathrm{E}$ & $\mathrm{F}$ & G & $\mathrm{H}$ \\
\hline DG129 & 3 & 60,607 & & & C & D & E & $\mathrm{F}$ & G & $\mathrm{H}$ \\
\hline DG70 & 1 & 60,537 & & & $\mathrm{C}$ & D & $\mathrm{E}$ & $\mathrm{F}$ & G & $\mathrm{H}$ \\
\hline DG42 & 1 & 60,040 & & & & D & $\mathrm{E}$ & $\mathrm{F}$ & G & $\mathrm{H}$ \\
\hline DG67 & 1 & 59.997 & & & & D & E & $\mathrm{F}$ & G & $\mathrm{H}$ \\
\hline DG68 & 1 & 59,767 & & & & D & $\mathrm{E}$ & $\mathrm{F}$ & G & $\mathrm{H}$ \\
\hline DG127 & 3 & 59,567 & & & & D & $\mathrm{E}$ & $\mathrm{F}$ & G & $\mathrm{H}$ \\
\hline DG117 & 2 & 59,467 & & & & D & E & $\mathrm{F}$ & G & $\mathrm{H}$ \\
\hline DG111 & 2 & 59.313 & & & & D & E & $\mathrm{F}$ & G & $\mathrm{H}$ \\
\hline DG118 & 2 & 59,137 & & & & D & $\mathrm{E}$ & $\mathrm{F}$ & G & $\mathrm{H}$ \\
\hline DG113 & 2 & 58,643 & & & & & E & $\mathrm{F}$ & G & $\mathrm{H}$ \\
\hline DG134 & 3 & 58.593 & & & & & E & $\mathrm{F}$ & G & $\mathrm{H}$ \\
\hline DG119 & 2 & 58.190 & & & & & $\mathrm{E}$ & $\mathrm{F}$ & G & $\mathrm{H}$ \\
\hline DG126 & 3 & 57,987 & & & & & E & $\mathrm{F}$ & G & $\mathrm{H}$ \\
\hline DG61 & 1 & 57,953 & & & & & $\mathrm{E}$ & $\mathrm{F}$ & G & $\mathrm{H}$ \\
\hline DG38 & 1 & 57,843 & & & & & $\mathrm{E}$ & $\mathrm{F}$ & G & $\mathrm{H}$ \\
\hline DG43 & 1 & 57.817 & & & & & E & $\mathrm{F}$ & G & $\mathrm{H}$ \\
\hline DG130 & 3 & 57,783 & & & & & $\mathrm{E}$ & $\mathrm{F}$ & G & $\mathrm{H}$ \\
\hline DG132 & 3 & 57,320 & & & & & $\mathrm{E}$ & $\mathrm{F}$ & G & $\mathrm{H}$ \\
\hline DG39 & 1 & 56,823 & & & & & & $\mathrm{~F}$ & G & $\mathrm{H}$ \\
\hline DG131 & 3 & 56.123 & & & & & & $\mathrm{~F}$ & G & $\mathrm{H}$ \\
\hline DG128 & 3 & 55,343 & & & & & & & G & $\mathrm{H}$ \\
\hline DG124 & 2 & 53.390 & & & & & & & & $\mathrm{H}$ \\
\hline
\end{tabular}

Região 1: Rio Negro - Bacia Amazònica

Região 2: Rio Solimões - Bacia Amazònica

Região 3: Litoral 5ul - SP 
Tabela 37.1 Estimativas da correlações fenotipicas entre os descritores contínuos.

\begin{tabular}{|c|c|c|c|c|c|c|c|c|c|c|c|c|c|c|c|c|}
\hline Descritor & 15 & 16 & 17 & 18 & 19 & 20 & 21 & 22 & 23 & 24 & 25 & 26 & 28 & 29 & 30 & 31 \\
\hline 15 (PR) & 1,00 & 0,74 & 0,66 & 0,84 & 0,99 & $-0,36$ & 0,26 & $-0,14$ & 0,01 & $-0,01$ & 0,26 & 0,08 & 0,17 & $-0,06$ & 0,16 & $-0,23$ \\
\hline 16 (PA) & 0,74 & 1,00 & 0,06 & 0,73 & 0,74 & $-0,14$ & 0,31 & $-0,08$ & 0,13 & 0,10 & 0,09 & 0,19 & 0,07 & $-0,19$ & $-0,04$ & $-0,03$ \\
\hline 17 (IC) & 0,66 & 0,06 & 1,00 & 0,50 & 0,64 & $-0,37$ & 0,06 & $-0,10$ & $-0,19$ & $-0,12$ & 0,23 & $-0,17$ & 0,15 & 0,05 & 0.34 & -0.30 \\
\hline 18 (NR) & 0,84 & 0,73 & 0,50 & 1.00 & 0,83 & -0.39 & 0,26 & $-0,20$ & 0,07 & 0,10 & 0.17 & 0,08 & 0.06 & -0.07 & 0.07 & -0.19 \\
\hline 19 (AS) & 0,99 & 0,74 & 0.64 & 0.83 & 1,00 & -0.40 & 0.22 & $-0,13$ & 0,03 & $-0,02$ & 0.26 & 0,06 & 0.18 & -0.03 & 0,17 & $-0,23$ \\
\hline 20( & $-0,36$ & $-0,14$ & $-0,37$ & -0.39 & $-0,40$ & 1,00 & 0.29 & $-0,19$ & 0,02 & 0,02 & -0.33 & 0,09 & -0.13 & $-0,21$ & -0.16 & 0.28 \\
\hline 21 (CNLF) & 0,26 & 0,31 & 0,06 & 0,26 & 0.22 & 0,29 & 1,00 & -0.29 & 0.01 & 0,09 & -0.05 & $-0,01$ & 0.12 & $-0,18$ & 0,01 & -0.08 \\
\hline 2 (MSF) & $-0,14$ & $-0,08$ & $-0,10$ & $-0,20$ & $-0,13$ & $-0,19$ & $-0,29$ & 1,00 & 0,16 & $-0,03$ & $-0,05$ & 0,05 & $-0,06$ & $-0,09$ & $-0,08$ & 0,20 \\
\hline $3(\mathrm{PrF})$ & 0,01 & 0,13 & $-0,19$ & 0,07 & 0,03 & 0,02 & 0,01 & 0,16 & 1,00 & 0,15 & $-0,01$ & 0,15 & $-0,03$ & $-0,08$ & $-0,13$ & 0.23 \\
\hline & 01 & 10 & $-0,12$ & 0,10 & $-0,02$ & 0,02 & 0,09 & $-0,03$ & 0,15 & 00 & 0,22 & $-0,08$ & $-0,07$ & 0 & $-0,04$ & 0,11 \\
\hline & 26 & 0,09 & 0,23 & 0,17 & 0,26 & $-0,33$ & $-0,05$ & $-0,05$ & $-0,01$ & 0.22 & 1,00 & 0,10 & 0,09 & 0,03 & $-0,03$ & 0,11 \\
\hline $6(\mathrm{~F}$ & 0,08 & 0,19 & $-0,17$ & 0,08 & 0,06 & 0,09 & $-0,01$ & 0,05 & 0,15 & $-0,08$ & 0,10 & 1,00 & 0,11 & $-0,26$ & $-0,27$ & 0,19 \\
\hline $28(\mathrm{~L}$ & 17 & 0,07 & 0,15 & 0,06 & 0,18 & $-0,13$ & 0,12 & $-0,06$ & $-0,03$ & $-0,07$ & 0,09 & 0,11 & 1,00 & 0,23 & 0,25 & $-0,43$ \\
\hline $\mathrm{zC})$ & $-0,06$ & $-0,19$ & 0,05 & $-0,07$ & $-0,03$ & $-0,21$ & $-0,18$ & $-0,09$ & $-0,08$ & 0,01 & 0,03 & $-0,26$ & 0,23 & 1,00 & 0,46 & $-0,36$ \\
\hline & & $-0,04$ & 0,34 & 0,07 & 0,17 & $-0,16$ & 0,01 & $-0,08$ & $-0,13$ & $-0,04$ & $-0,03$ & $-0,27$ & 0,25 & 0,46 & 1,00 & $-0,46$ \\
\hline $31(\mathrm{~F}$ & $-0,23$ & $-0,03$ & $-0,30$ & $-0,19$ & $-0,23$ & 0,28 & $-0,08$ & 0,20 & 0,23 & 0,11 & 0,11 & 0,19 & $-0,43$ & $-0,36$ & $-0,46$ & 1,00 \\
\hline $32(\mathrm{~N}$ & & 0,05 & 0,12 & 0,06 & 0,13 & $-0,23$ & $-0,04$ & $-0,17$ & -0.12 & $-0,11$ & $-0,01$ & $-0,03$ & 0,25 & 0,15 & 0,41 & $-0,41$ \\
\hline 33( & 0,39 & 0,36 & 0,23 & 0,34 & 0,38 & $-0,28$ & $-0,01$ & $-0,17$ & $-0,10$ & $-0,20$ & $-0,06$ & $-0,06$ & 0.21 & 0,05 & 0,01 & $-0,55$ \\
\hline $34(6)$ & 0,18 & 0,24 & 0,03 & 0,04 & 0,15 & 0,12 & 0,06 & 0,25 & 0.32 & $-0,02$ & 0,00 & 0,13 & 0,07 & $-0,13$ & 0,07 & 0,02 \\
\hline 35( & 0,19 & 0,25 & 0,04 & 0,06 & 0,17 & 0,10 & 0,06 & 0,23 & 0,30 & $-0,01$ & 0,03 & 0,17 & 0,10 & $-0,14$ & 0.06 & 0,02 \\
\hline 36( & $-0,12$ & $-0,09$ & $-0,03$ & $-0,10$ & $-0,15$ & 0,20 & 0,16 & 0,10 & 0,29 & 0,11 & $-0,04$ & $-0,20$ & $-0,11$ & 0,03 & 0,08 & 0,12 \\
\hline 37 (CNLPR) & $-0,13$ & $-0,11$ & 0,01 & $-0,10$ & $-0,15$ & 0,14 & 0,11 & 0,12 & 0,28 & 0,08 & 0,01 & $-0,24$ & $-0,07$ & 0,12 & 0.14 & 0,08 \\
\hline 38 (UER) & & 0,41 & 0,17 & 0,46 & 0,36 & $-0,26$ & 0,25 & 0,06 & 0,01 & 0,15 & 0,05 & 0,08 & 0.40 & 0,02 & 0.02 & $-0,38$ \\
\hline & $-0,54$ & $-0,39$ & $-0,45$ & $-0,49$ & $-0,64$ & 0,43 & $-0,04$ & 0,00 & $-0,08$ & 0,23 & $-0,08$ & 0,08 & -0.11 & $-0,03$ & $-0,16$ & 0,23 \\
\hline 40 (PrR) & $-0,01$ & $-0,20$ & 0,20 & $-0,17$ & $-0,04$ & 0,06 & $-0,13$ & 0,08 & 0,07 & 0,02 & 0,11 & 0,07 & 0,08 & 0,14 & 0,29 & 0,13 \\
\hline $41(\mathrm{AR})$ & 0,36 & 0,38 & 0,17 & 0,43 & 0,43 & $-0,29$ & 0,09 & $-0,05$ & 0,01 & $-0,20$ & $-0,04$ & $-0,06$ & $-0,09$ & $-0,06$ & $-0,08$ & $-0,17$ \\
\hline 42( & 0,14 & $-0,09$ & 0,38 & 0,22 & 0,15 & $-0,06$ & 0,12 & $-0,09$ & 0.03 & 0,18 & 0,12 & $-0,18$ & $-0,03$ & 0,07 & 0,22 & -0.07 \\
\hline 43 (CzR) & $-0,27$ & $-0,29$ & $-0,13$ & $-0,29$ & $-0,34$ & 0,18 & 0,02 & $-0,10$ & 0,00 & 0,16 & $-0,05$ & $-0,01$ & 0,18 & 0,26 & 0,12 & 0,05 \\
\hline 44 (FR) & $-0,48$ & $-0,33$ & $-0,41$ & $-0,52$ & $-0,55$ & 0,39 & $-0,08$ & 0,03 & $-0,09$ & 0,22 & 0,03 & 0,03 & $-0,02$ & $-0,16$ & $-0,10$ & 0,24 \\
\hline 45 (AçR) & $-0,03$ & $-0,13$ & 0,06 & 0,00 & $-0,10$ & $-0,04$ & 0,08 & 0,05 & 0,05 & 0,10 & 0.08 & 0,07 & $-0,15$ & 0,08 & $-0,05$ & $-0,08$ \\
\hline 46 (UR) & $-0,53$ & $-0,37$ & $-0,49$ & $-0,48$ & $-0,61$ & 0,42 & $-0,06$ & 0,01 & -0.01 & 0,25 & $-0,08$ & 0,09 & $-0,08$ & 0,00 & $-0,18$ & 0.26 \\
\hline
\end{tabular}


Tabela 37.2 Estimativas das correlações fenotípicas entre os descritores contínuos. Continuação.

\begin{tabular}{|c|c|c|c|c|c|c|c|c|c|c|c|c|c|c|c|}
\hline Descritor & 32 & 33 & 34 & 35 & 36 & 37 & 38 & 39 & 40 & 41 & 42 & 43 & 44 & 45 & 46 \\
\hline 15 (PR) & & 0.39 & 0,18 & & & $-0,13$ & & & $-0,01$ & 0.36 & & & & & \\
\hline & .05 & 0,36 & 0,24 & 25 & $-0,09$ & $-0,11$ & 0,41 & $-0,39$ & $-0,20$ & 0,38 & -0 & .29 & 0,33 & 0,15 & $-0,37$ \\
\hline 17 (I & 12 & 0.23 & 0.03 & 0.04 & $-0,03$ & 0.01 & 0,17 & $-0,45$ & 0,20 & 0.17 & 0,38 & .13 & .41 & 0.06 & $-0,49$ \\
\hline 18( & .06 & 0,34 & 0.04 & 0,06 & -0.10 & -0.10 & 0,46 & $-0,49$ & $-0,17$ & 0.43 & 0.22 & -0.29 & -0.52 & 0.00 & -0.48 \\
\hline $19(A$ & 0,13 & 0.38 & 0,15 & 0.17 & -0.15 & $-0,15$ & 0.36 & $-0,64$ & $-0,04$ & 0.43 & 0,15 & -0.34 & -0.55 & $-0,10$ & -0.61 \\
\hline 20 & -0.23 & -0.28 & 0.12 & 0,10 & 0.20 & 0.14 & -0.26 & 0,43 & 0,06 & $-0,29$ & $-0,06$ & 0.18 & 0.39 & -0.04 & 0.42 \\
\hline & -0.04 & $-0,01$ & 0,06 & 0,06 & 0.16 & 11 & 0,25 & $-0,04$ & $-0,13$ & 0,09 & 0.12 & 0.02 & -0.08 & 0,08 & -0.06 \\
\hline $22(1$ & $-0,17$ & $-0,17$ & 0,25 & 0.23 & 0.10 & 0,12 & 0,06 & 0,00 & 0,08 & $-0,05$ & $-0,09$ & -0.10 & 0.03 & 0.05 & 0.01 \\
\hline $3(\mathrm{P}$ & $-0,12$ & $-0,10$ & 0,32 & 0,30 & 0.29 & 0,28 & 0,01 & $-0,08$ & 0,07 & 0,01 & 0.03 & 0,00 & $-0,09$ & 0,05 & $-0,01$ \\
\hline 1GF) & $-0,11$ & $-0,20$ & $-0,02$ & $-0,01$ & 0,11 & 0,08 & 0,15 & 0,23 & 0,02 & $-0,20$ & 0,18 & 0,16 & 0,22 & 0,10 & 0,25 \\
\hline & $-0,01$ & $-0,06$ & 0,00 & 0,03 & $-0,04$ & 0,01 & 0,05 & $-0,08$ & 0,11 & $-0,04$ & 0,12 & -0.05 & .03 & 0,08 & $-0,08$ \\
\hline & $-0,03$ & $-0,06$ & 0,13 & 0,17 & $-0,20$ & $-0,24$ & 0,08 & 0,08 & 0,07 & $-0,06$ & $-0,18$ & $-0,01$ & 0,03 & 0,07 & 0,09 \\
\hline & & 0,21 & 0,07 & 0,10 & $-0,11$ & $-0,07$ & 0,40 & $-0,11$ & 0,08 & & $-0,03$ & 0,18 & $-0,02$ & $-0,15$ & $-0,08$ \\
\hline $29(\mathrm{CzC})$ & 0,15 & 0,05 & $-0,13$ & $-0,14$ & 0,03 & 0,12 & 0,02 & $-0,03$ & 0,14 & $-0,06$ & 0,07 & 0,26 & $-0,16$ & 0,08 & 0,00 \\
\hline & & 0,01 & 0,07 & 0,06 & 0,08 & 0,14 & 0,02 & $-0,16$ & 0,29 & $-0,08$ & 0,22 & 0,12 & $-0,10$ & $-0,05$ & $-0,18$ \\
\hline & 0,41 & $-0,55$ & 0,02 & 0,02 & 0,12 & 0,08 & $-0,38$ & 0,23 & 0,13 & $-0,17$ & $-0,07$ & 0.05 & 24 & $-0,08$ & 0,26 \\
\hline SC) & 1.00 & 0,37 & $-0,03$ & $-0,01$ & $-0,13$ & $-0,10$ & 0,13 & $-0,16$ & $-0,06$ & 08 & -0.14 & 0.03 & -0.07 & $-0,10$ & -0.17 \\
\hline 33( & & 1,00 & 0,25 & 0,26 & $-0,17$ & $-0,20$ & 0,27 & -0.30 & $-0,33$ & 0 , & $-0,25$ & -0.17 & $-0,21$ & $-0,01$ & -0.33 \\
\hline NTER) & $-0,03$ & 0,25 & 1,00 & 0,98 & 0,34 & 0,31 & 0,02 & $-0,09$ & 0,04 & $-0,04$ & $-0,02$ & -0.03 & 0,07 & $-0,09$ & $-0,11$ \\
\hline NLER) & $-0,01$ & 0,26 & 0,98 & 1,00 & 0.32 & 0,30 & 0,03 & $-0,10$ & 0,03 & $-0,02$ & $-0,02$ & $-0,06$ & 0.06 & $-0,11$ & $-0,12$ \\
\hline NTPR) & $-0,13$ & $-0,17$ & 0,34 & 0,32 & 1,00 & 0,96 & $-0,11$ & 0,17 & 0,26 & $-0,25$ & 0,17 & 0.33 & .10 & 0,06 & 0,12 \\
\hline NLPR) & $-0,10$ & $-0,20$ & 0,31 & 0,30 & 0,96 & 1,00 & $-0,10$ & 0,13 & 0,31 & $-0,29$ & 0.21 & 0.37 & 0,11 & 0,06 & 0,10 \\
\hline 38( & & 0,27 & 0,02 & 0,03 & $-0,11$ & $-0,10$ & 1,00 & 0,06 & $-0,08$ & $-0,06$ & 0,00 & 0,17 & $-0,01$ & 0,15 & 0.07 \\
\hline & $-0,16$ & $-0,30$ & $-0,09$ & $-0,10$ & 0,17 & 0,13 & 0,06 & 1,00 & 0,23 & $-0,70$ & $-0,23$ & 0.60 & 0.73 & 0,29 & 0,97 \\
\hline 40 (PrR) & $-0,06$ & $-0,33$ & 0,04 & 0,03 & 0,26 & 0,31 & $-0,08$ & 0,23 & 1,00 & $-0,73$ & 0,11 & 0.56 & 0,30 & 0,17 & 0,22 \\
\hline AR) & 0,08 & 0,33 & $-0,04$ & $-0,02$ & $-0,25$ & $-0,29$ & $-0,06$ & $-0,70$ & $-0,73$ & 1,00 & $-0,02$ & $-0,84$ & $-0,82$ & $-0,26$ & $-0,69$ \\
\hline 42 (MGR) & $-0,14$ & $-0,25$ & $-0,02$ & $-0,02$ & 0.17 & 0,21 & 0,00 & $-0,23$ & 0,11 & $-0,02$ & 1,00 & 0,01 & $-0,14$ & 0,06 & -0.26 \\
\hline & & $-0,17$ & $-0,03$ & $-0,06$ & 0,33 & 0,37 & 0,17 & 0,60 & 0,56 & $-0,84$ & 0,01 & 1.00 & 0,58 & 0,10 & 0,64 \\
\hline & -0.07 & $-0,21$ & 0,07 & 0,06 & 0,10 & 0,11 & $-0,01$ & 0.73 & 0,30 & $-0,82$ & $-0,14$ & 0.58 & 1,00 & 0,18 & 0.72 \\
\hline 45 (AçR) & $-0,10$ & $-0,01$ & $-0,09$ & $-0,11$ & 0,06 & 0,06 & 0,15 & 0,29 & 0,17 & $-0,26$ & 0,06 & 0.10 & 0,18 & 1,00 & 0,23 \\
\hline 46 (UR) & $-0,17$ & $-0,33$ & $-0,11$ & $-0,12$ & 0,12 & 0,10 & 0,07 & 0,97 & 0,22 & $-0,69$ & $-0,26$ & 0.64 & 0,72 & 0,23 & 1,00 \\
\hline
\end{tabular}


Tabela 38.1 Estimativas das correlações genéticas entre os descritores contínuos.

\begin{tabular}{|c|c|c|c|c|c|c|c|c|c|c|c|c|c|c|c|c|}
\hline Descritor & 15 & 16 & 17 & 18 & 19 & 20 & 21 & 22 & 23 & 24 & 25 & 26 & 28 & 29 & 30 & 31 \\
\hline 5 (PR) & 1,00 & 0,75 & 0,73 & $\mathbf{0 , 8 7}$ & 0,99 & $-0,53$ & & $-0,28$ & 0,00 & $-0,01$ & 0,31 & 0,08 & 0,21 & $-0,08$ & 0,18 & $-0,24$ \\
\hline & 0,75 & 1,00 & 0,15 & 0,76 & 0,75 & $-0,24$ & 0,43 & -0.08 & 0,15 & 0,09 & 0,11 & 0,22 & 0,16 & $-0,22$ & & $-0,05$ \\
\hline 17 (I & 0,73 & 0,15 & 1.00 & 0,58 & 0,72 & $-0,55$ & 0,13 & -0.30 & $-0,23$ & $-0,12$ & 0,28 & $-0,20$ & 0.15 & 0.04 & 0.36 & 0.32 \\
\hline 18 (NR) & 0,87 & 0,76 & 0.58 & 1,00 & 0,87 & $-0,58$ & 0.37 & $-0,31$ & 0.10 & 0,12 & 0,17 & 0,07 & 0.13 & -0.07 & 0,08 & -0.20 \\
\hline 19 (AS) & 0,99 & 0,75 & 0,72 & $\mathbf{0 , 8 7}$ & 1.00 & -0.58 & 0.31 & $-0,28$ & 0.01 & -0.04 & 0.32 & 0.06 & 0.23 & -0.04 & 0.18 & -0.24 \\
\hline 20 (CNTF) & -0.53 & $-0,24$ & $-0,55$ & -0.58 & $-0,58$ & 1.00 & -0.02 & 0,21 & 0.08 & 0.02 & $-0,49$ & 0.14 & -0.26 & -0.30 & -0.25 & 0.40 \\
\hline & 36 & 0,43 & 0,13 & 0,37 & 0,31 & $-0,02$ & 1,00 & $-0,37$ & 13 & 0.10 & -0.07 & -0.02 & 0.24 & $-0,26$ & .01 & $-0,10$ \\
\hline 22( & $-0,28$ & $-0,08$ & $-0,30$ & $-0,31$ & $-0,28$ & 0,21 & $-0,37$ & 1,00 & 0,40 & 0,01 & $-0,16$ & 0,04 & $-0,29$ & $-0,18$ & $-0,11$ & 0,36 \\
\hline & 0,00 & 0,15 & $-0,23$ & 0,10 & 0,01 & 0,08 & 0,13 & 0,40 & 1,00 & 0,26 & 0,08 & 0,21 & $-0,08$ & $-0,10$ & -0.17 & 0,30 \\
\hline 24 (MGF) & $-0,01$ & 0,09 & $-0,12$ & 0,12 & $-0,04$ & 0,02 & 0,10 & 0,01 & 0,26 & 1,00 & 0,30 & $-0,10$ & $-0,07$ & 0,02 & $-0,04$ & 0,13 \\
\hline$\Gamma$ & 0,31 & 0,11 & 0,28 & 0,17 & 0,32 & $-0,49$ & $-0,07$ & $-0,16$ & 0,08 & 0.30 & 1,00 & 0,12 & 0,11 & 0,03 & $-0,03$ & 0,14 \\
\hline & 08 & 22 & $-0,20$ & 0,07 & 0,06 & 0,14 & $-0,02$ & 0,04 & 0,21 & $-0,10$ & 0,12 & 00 & 0,15 & $-0,28$ & $-0,29$ & 0,20 \\
\hline 28 & 0,21 & 0,16 & 0.15 & 0,13 & 0,23 & $-0,26$ & 0,24 & $-0,29$ & $-0,08$ & $-0,07$ & 0,11 & 0,15 & 1,00 & 0,31 & 0,32 & $-0,59$ \\
\hline $29(\mathrm{CzC})$ & $-0,08$ & $-0,22$ & 0,04 & $-0,07$ & $-0,04$ & $-0,30$ & $-0,26$ & $-0,18$ & $-0,10$ & 0,02 & 0,03 & $-0,28$ & 0,31 & 1,00 & 0,47 & $-0,37$ \\
\hline C) & 18 & $-0,04$ & 0,36 & 0,08 & 0,18 & $-0,25$ & 0,01 & $-0,11$ & $-0,17$ & $-0,04$ & $-0,03$ & $-0,29$ & 0,32 & 0,47 & 1,00 & $-0,47$ \\
\hline & $-0,24$ & $-0,05$ & $-0,32$ & $-0,20$ & $-0,24$ & 0,40 & $-0,10$ & 0,36 & 0,30 & 0,13 & 0,14 & 0,20 & $-0,59$ & $-0,37$ & -0.47 & 1,00 \\
\hline GC) & 0,13 & 0,07 & 0,14 & 0,08 & 0,15 & $-0,42$ & $-0,10$ & $-0,23$ & $-0,12$ & $-0,17$ & $-0,01$ & $-0,04$ & 0,40 & 0,17 & 0.43 & $-0,43$ \\
\hline 33( & 51 & 0,49 & 0,31 & 0,46 & 0,48 & $-0,56$ & $-0,03$ & $-0,37$ & $-0,06$ & $-0,28$ & $-0,05$ & $-0,04$ & 0,38 & 0,06 & 0,01 & $-0,66$ \\
\hline NTER) & 0,18 & 0.26 & 0,03 & 0,04 & 0,16 & 0,18 & 0,07 & 0,44 & 0,42 & $-0,03$ & $-0,01$ & 0,15 & 0,10 & $-0,13$ & 0,07 & 0,02 \\
\hline & 0,20 & 0,27 & 0,04 & 0,06 & 0,18 & 0,15 & 0,09 & 0,39 & 0,41 & $-0,01$ & 0,03 & 0,18 & 0,14 & $-0,14$ & 0.06 & 0,02 \\
\hline (NTPR) & $-0,11$ & $-0,07$ & $-0,05$ & $-0,08$ & $-0,14$ & 0,27 & 0,21 & 0,20 & 0,44 & 0,13 & $-0,04$ & $-0,23$ & $-0,19$ & 0,03 & 0.08 & 0.12 \\
\hline NLPR) & $-0,12$ & $-0,10$ & 0,00 & $-0,09$ & $-0,15$ & 0,21 & 0,17 & 0,24 & 0,39 & 0,09 & 0,02 & $-0,27$ & $-0,15$ & 0,12 & 0.14 & 0,09 \\
\hline 38 (UER) & 0,55 & 0,59 & 0,20 & 0,61 & 0,47 & $-0,67$ & 0,30 & 0,18 & $-0,04$ & 0.24 & 0.07 & 0.16 & 0,60 & 0,02 & 0.04 & $-0,52$ \\
\hline 39( & $-0,64$ & $-0,49$ & $-0,55$ & $-0,59$ & $-0,71$ & 0,63 & $-0,08$ & 0,08 & $-0,06$ & 0,29 & -0.12 & 0,08 & $-0,16$ & $-0,03$ & $-0,18$ & 0.25 \\
\hline & $-0,01$ & $-0,22$ & 0,22 & $-0,18$ & $-0,05$ & 0,09 & $-0,16$ & 0,14 & 0.09 & 0,03 & 0,12 & 0,07 & 0,10 & 0,14 & 0,29 & 0,13 \\
\hline 41 (AR) & 0,38 & 0,43 & 0,18 & 0,45 & 0,46 & $-0,42$ & 0,12 & $-0,11$ & 0,01 & $-0,24$ & $-0,05$ & $-0,07$ & $-0,12$ & $-0,06$ & $-0,08$ & $-0,17$ \\
\hline 1GR) & 0,18 & $-0,07$ & 0,46 & 0,30 & 0,18 & $-0,06$ & 0,15 & $-0,15$ & 0,04 & 0,23 & 0,11 & $-0,20$ & $-0,09$ & 0,08 & 0,26 & $-0,07$ \\
\hline $43(\mathrm{CzR})$ & $-0,30$ & $-0,33$ & $-0,15$ & $-0,32$ & $-0,36$ & 0,26 & 0,03 & $-0,16$ & $-0,01$ & 0,20 & $-0,06$ & $-0,01$ & 0,23 & 0,27 & 0,12 & 0,05 \\
\hline & $-0,51$ & $-0,37$ & $-0,45$ & $-0,55$ & $-0,58$ & 0,58 & $-0,10$ & 0,06 & $-0,13$ & 0,26 & 0,04 & 0,03 & $-0,02$ & $-0,16$ & $-0,10$ & 0,25 \\
\hline 45 (AçR) & $-0,03$ & $-0,15$ & 0,08 & 0,00 & $-0,11$ & $-0,05$ & 0,08 & 0.04 & 0,10 & 0,13 & 0,10 & 0,08 & $-0,20$ & 0,08 & $-0,06$ & $-0,09$ \\
\hline 46 (UR) & $-0,64$ & $-0,46$ & $-0,64$ & $-0,58$ & $-0,70$ & 0,61 & $-0,10$ & 0,11 & 0,03 & 0,31 & $-0,11$ & 0,11 & $-0,12$ & $-0,01$ & -0.20 & 0,29 \\
\hline
\end{tabular}


Tabela 38.2 Estimativas das correlações genéticas entre os descritores contínuos. Continuação.

\begin{tabular}{|c|c|c|c|c|c|c|c|c|c|c|c|c|c|c|c|}
\hline & 32 & 33 & 34 & 35 & 36 & 37 & 38 & 39 & 40 & 41 & 42 & 43 & 44 & 45 & 46 \\
\hline 15 (PR) & & 0,51 & 0,18 & & & $-0,12$ & & $-0,64$ & $-0,01$ & & & & & & \\
\hline $16(\mathrm{PA})$ & 0,07 & 0,49 & 0,26 & 0,27 & & $-0,10$ & 0,59 & $-0,49$ & $-0,22$ & 0,43 & & $-0,33$ & & $-0,15$ & $-0,46$ \\
\hline 17 (IC) & 0,14 & 0,31 & 0,03 & 0,04 & -0.05 & 0,00 & 0,20 & -0.55 & 0.22 & 0.18 & 0,46 & -0.15 & $-0,45$ & 0.08 & $-0,64$ \\
\hline $18(\mathrm{NR})$ & 0,08 & 0,46 & 0,04 & 0,06 & $-0,08$ & $-0,09$ & 0,61 & $-0,59$ & $-0,18$ & 0,45 & 0,30 & $-0,32$ & -0.55 & 0,00 & -0.58 \\
\hline 19 (AS) & 0.15 & 0,48 & 0.16 & 0.18 & $-0,14$ & $-0,15$ & 0,47 & $-0,71$ & $-0,05$ & 0.46 & 0.18 & -0.36 & -0.58 & $-0,11$ & $-0,70$ \\
\hline $20(\mathrm{C})$ & $-0,42$ & $-0,56$ & 0,18 & 0,15 & 27 & 0,21 & $-0,67$ & 0,63 & 0,09 & -0.42 & $-0,06$ & 0,26 & 0.58 & $-0,05$ & 0,61 \\
\hline & $-0,10$ & $-0,03$ & 0.07 & 0,09 & 0.21 & 0,17 & 0,30 & $-0,08$ & $-0,16$ & 0,12 & 0,15 & 0,03 & $-0,10$ & 0,08 & -0.10 \\
\hline $22(1$ & $-0,23$ & $-0,37$ & 0,44 & 0,39 & 0,20 & 0,24 & 0,18 & 0,08 & 0,14 & $-0,11$ & $-0,15$ & $-0,16$ & 0.06 & 0,04 & 0.11 \\
\hline 23 (PrF) & $-0,12$ & $-0,06$ & 0,42 & 0,41 & 0,44 & 0,39 & $-0,04$ & $-0,06$ & 0,09 & 0,01 & 0,04 & $-0,01$ & $-0,13$ & 0,10 & 0,03 \\
\hline 24 (MGF) & $-0,17$ & $-0,28$ & $-0,03$ & $-0,01$ & 0,13 & 0,09 & 0,24 & 0,29 & 0,03 & $-0,24$ & 0,23 & 0,20 & 0,26 & 0,13 & 0,31 \\
\hline & $-0,0$ & $-0,05$ & $-0,01$ & 0,03 & $-0,04$ & 0,02 & 0,07 & $-0,12$ & 0,12 & $-0,0$ & 0,11 & $-0,06$ & 04 & 0,10 & $-0,11$ \\
\hline & $-0,04$ & $-0,04$ & 0,15 & 0,18 & $-0,23$ & $-0,27$ & 0,16 & 0,08 & 0,07 & $-0,07$ & $-0,20$ & $-0,01$ & 0,03 & 0,08 & 0,11 \\
\hline & 0,40 & 0,38 & 0,10 & 0,14 & $-0,19$ & $-0,15$ & 0,60 & $-0,16$ & 0,10 & & $-0,09$ & 0,23 & $-0,02$ & $-0,20$ & $-0,12$ \\
\hline 29 ( & 0,17 & 0,06 & $-0,13$ & $-0,14$ & 0,03 & 0,12 & 0,02 & $-0,03$ & 0,14 & $-0,06$ & 0,08 & 0,27 & $-0,16$ & 0,08 & $-0,01$ \\
\hline $30(\mathrm{~F}$ & 0,43 & 0,01 & 0,07 & 0,06 & 0,08 & 0,14 & & $-0,18$ & 0,29 & $-0,08$ & 0,26 & 0,12 & $-0,10$ & $-0,06$ & -0.20 \\
\hline 311 & $-0,43$ & $-0,66$ & 0,02 & 0,02 & 0,12 & 0,09 & $-0,52$ & 0,25 & 0,13 & $-0,17$ & $-0,07$ & 0,05 & 0,25 & $-0,09$ & 0,29 \\
\hline 32( & & 0,50 & $-0,02$ & 0,00 & $-0,14$ & $-0,12$ & 0 & $-0,21$ & $-0,07$ & & $-0,16$ & 0,04 & -0.07 & $-0,08$ & $-0,21$ \\
\hline 33( & & 1,00 & 0,31 & 0,32 & $-0,20$ & $-0,22$ & 0,43 & $-0,35$ & $-0,40$ & 0,40 & -0 & $-0,21$ & $-0,26$ & $-0,01$ & $-0,40$ \\
\hline $34(C$ & $-0,02$ & 0,31 & 1,00 & 0,99 & 0,36 & 0,33 & 0,04 & $-0,09$ & 0,04 & $-0,04$ & -0.02 & -0.03 & 0,07 & $-0,11$ & $-0,12$ \\
\hline (NLER) & 0,00 & 0.32 & 0,99 & 1,00 & 0,34 & 0,32 & & & 0,03 & $-0,02$ & $-0,02$ & $-0,06$ & 06 & $-0,13$ & $-0,12$ \\
\hline NTPR) & $-0,14$ & $-0,20$ & 0,36 & 0,34 & 1,00 & 0,98 & $-0,14$ & 0,18 & 0,27 & $-0,26$ & 0.20 & 0.34 & 10 & 0,07 & 0.13 \\
\hline (NLPR) & $-0,12$ & $-0,22$ & 0,33 & 0,32 & 0,98 & 1,00 & $-0,13$ & 0,14 & 0,33 & $-0,31$ & 0,26 & 0,39 & 0,12 & 0,08 & 0.11 \\
\hline 38 ( & 0,19 & 0,43 & 0,04 & 0,04 & -0.14 & $-0,13$ & 1,00 & 0,01 & $-0,10$ & $-0,08$ & 0,02 & 0.22 & $-0,02$ & 0,22 & 0,01 \\
\hline 39( & $-0,2$ & $-0,35$ & $-0,09$ & $-0,10$ & & 0,14 & 0,01 & 1,00 & 0,25 & $-0,77$ & $-0,26$ & 0,66 & $\mathbf{0 , 8 0}$ & 0,38 & 1,00 \\
\hline R) & $-0,07$ & $-0,40$ & 0,04 & 0,03 & 0,27 & 0,33 & $-0,10$ & 0,25 & 1,00 & $-0,73$ & 0,12 & 0,57 & 0,30 & 0,19 & 0,25 \\
\hline AR) & 0,08 & 0,40 & $-0,04$ & $-0,02$ & $-0,26$ & $-0,31$ & $-0,08$ & $-0,77$ & $-0,73$ & 1,00 & $-0,04$ & $-0,85$ & $-0,82$ & $-0,28$ & $-0,77$ \\
\hline 42 (MGR) & $-0,16$ & $-0,41$ & $-0,02$ & $-0,02$ & 0,20 & 0,26 & 0,02 & $-0,26$ & 0,12 & $-0,04$ & 1,00 & 0,01 & $-0,16$ & 0,11 & $-0,32$ \\
\hline $43(C$ & 0,04 & $-0,21$ & $-0,03$ & $-0,06$ & 0,34 & 0,39 & 0,22 & 0,66 & 0,57 & $-0,85$ & 0,01 & 1.00 & 0,58 & 0,11 & 0,71 \\
\hline $44(\mathrm{I}$ & $-0,07$ & $-0,26$ & 0,07 & 0,06 & 0,10 & 0,12 & $-0,02$ & 0,80 & 0.30 & $-0,82$ & $-0,16$ & 0,58 & 1,00 & 0.19 & $\mathbf{0 , 8 0}$ \\
\hline 45 (AçR) & $-0,08$ & $-0,01$ & $-0,11$ & $-0,13$ & 0,07 & 0,08 & 0,22 & 0,38 & 0,19 & $-0,28$ & 0,11 & 0,11 & 0,19 & 1,00 & 0,31 \\
\hline 46 (UR) & $-0,21$ & $-0,40$ & $-0,12$ & $-0,12$ & 0,13 & 0,11 & 0,01 & 1,00 & 0,25 & $-0,77$ & $-0,32$ & 0,71 & $\mathbf{0 , 8 0}$ & 0,31 & 1,00 \\
\hline
\end{tabular}


Tabela 39.1 Estimativas das correlaçōes ambientais entre os descritores contínuos.

\begin{tabular}{|c|c|c|c|c|c|c|c|c|c|c|c|c|c|c|c|c|}
\hline Descritor & 15 & 16 & 17 & 18 & 19 & 20 & 21 & 22 & 23 & 24 & 25 & 26 & 28 & 29 & 30 & 31 \\
\hline 15 (PR) & 1,00 & 0,73 & 0,16 & 0,56 & 0,95 & $-0,06$ & 0,01 & 0,03 & 0,06 & 0,03 & $-0,01$ & 0,07 & 0,06 & 0,18 & $-0,13$ & 0,04 \\
\hline $16(\mathrm{PA})$ & 0,73 & 1,00 & $-0,38$ & 0,61 & 0,68 & 0,03 & 0,09 & $-0,12$ & 0,11 & 0,11 & 0,00 & 0,00 & $-0,13$ & $-0,03$ & $-0,09$ & 0,16 \\
\hline 17 (IC) & 0,16 & $-0,38$ & 1,00 & $-0,05$ & 0,13 & $-0,08$ & $-0,11$ & 0.17 & $-0,12$ & $-0,12$ & 0,02 & 0,06 & $5 \quad 0,19$ & 0.20 & 0.07 & -0.28 \\
\hline 18 (NR) & 0,56 & 0,61 & $-0,05$ & 1.00 & 0.48 & $-0,05$ & $-0,04$ & $-0,16$ & 0,00 & 0,06 & 0,17 & 0.16 & $-0,14$ & -0.04 & -0.03 & 0.03 \\
\hline 19 (AS) & 0,95 & 0,68 & 0,13 & 0,48 & 1.00 & -0.07 & 0,01 & 0,07 & 0,08 & 0,06 & -0.03 & 0.02 & 0.05 & 0.13 & -0.10 & 0.03 \\
\hline 20 (CNTF) & $-0,06$ & 0,03 & $-0,08$ & $-0,05$ & $-0,07$ & 1,00 & 0,63 & $-0,45$ & $-0,05$ & 0,03 & $-0,08$ & 0.00 & 0,01 & -0.01 & 0,21 & 0,16 \\
\hline $21(C$ & 0,01 & 0,09 & $-0,11$ & $-0,04$ & 0,01 & 0,63 & 1,00 & $-0,24$ & $-0,14$ & 0,09 & $-0,01$ & $-0,01$ & $-0,03$ & 0,16 & 0,05 & 0,01 \\
\hline 22( & 0,03 & $-0,12$ & 0,17 & $-0,16$ & 0,07 & $-0,45$ & $-0,24$ & 1,00 & 0,00 & $-0,08$ & 0,06 & 0,09 & 0,11 & 0,10 & -0.17 & $-0,01$ \\
\hline 23 (PrF) & 0,06 & 0,11 & $-0,12$ & 0,00 & 0,08 & $-0,05$ & $-0,14$ & 0,00 & 1,00 & $-0,04$ & $-0,19$ & 0,02 & 0,03 & $-0,08$ & $-0,05$ & 0,14 \\
\hline 24 (MGF) & 0,03 & 0,11 & $-0,12$ & 0,06 & 0,06 & 0,03 & 0,09 & $-0,08$ & $-0,04$ & 1,00 & $-0,04$ & 0,00 & $-0,07$ & $-0,02$ & $-0,12$ & $-0,01$ \\
\hline $25(\mathrm{CzF})$ & $-0,01$ & 0,00 & 0,02 & 0,17 & $-0,03$ & $-0,08$ & $-0,01$ & 0,06 & $-0,19$ & $-0,04$ & 1,00 & 0,02 & 0,07 & 0,04 & $-0,04$ & $-0,12$ \\
\hline 26( & 0,07 & 0,00 & 0,06 & 0,16 & 0,02 & 0,00 & $-0,01$ & 0,09 & 0,02 & 0,00 & 0,02 & 1,00 & 0,01 & $-0,02$ & $-0,03$ & 0,07 \\
\hline 28( & 0,06 & $-0,13$ & 0,19 & $-0,14$ & 0,05 & 0,01 & $-0,03$ & 0,11 & 0,03 & $-0,07$ & 0,07 & 0,01 & 1,00 & $-0,01$ & 0,09 & 0,16 \\
\hline $29(\mathrm{CzC})$ & 0,18 & $-0,03$ & 0,20 & $-0,04$ & 0,13 & $-0,01$ & 0,16 & 0,10 & $-0,08$ & $-0,02$ & 0,04 & $-0,02$ & $-0,01$ & 1,00 & $-0,11$ & $-0,07$ \\
\hline $30(1$ & $-0,13$ & $-0,09$ & 0,07 & $-0,03$ & $-0,10$ & 0,21 & 0,05 & $-0,17$ & $-0,05$ & $-0,12$ & $-0,04$ & $-0,03$ & 0,09 & $-0,11$ & 1,00 & $-0,18$ \\
\hline $31(\mathrm{~F}$ & 0,04 & 0,16 & $-0,28$ & 0,03 & 0,03 & 0,16 & 0,0 & $-0,01$ & 0,14 & $-0,01$ & $-0,12$ & 0,07 & 0,16 & $-0,07$ & $-0,18$ & 1,00 \\
\hline & $-0,10$ & $-0,06$ & $-0,03$ & $-0,08$ & $-0,12$ & 0,16 & 0,1 & $-0,20$ & $-0,13$ & 0,13 & $-0,02$ & 0,03 & $-0,15$ & $-0,11$ & 0,02 & $-0,14$ \\
\hline 33( & $-0,04$ & 0,01 & 0,00 & $-0,06$ & 0,02 & 0,09 & 0,04 & $-0,01$ & $-0,15$ & $-0,03$ & $-0,06$ & $-0,11$ & $-0,07$ & 0,01 & 0,10 & $-0,14$ \\
\hline NTER) & 0,12 & 0,10 & $-0,08$ & 0,10 & 0.14 & $-0,03$ & 0,05 & 0,09 & 0,08 & 0,11 & 0,11 & $-0,17$ & 0,00 & 0,04 & $-0,07$ & 0,02 \\
\hline NLER) & 0,10 & 0,08 & $-0,08$ & 0,14 & 0,15 & $-0,10$ & $-0,06$ & 0,16 & $-0,02$ & 0,05 & 0,11 & $-0,11$ & $-0,04$ & $-0,07$ & $-0,09$ & 0,07 \\
\hline 36( & $-0,33$ & $-0,28$ & 0,14 & $-0,32$ & $-0,35$ & 0,10 & 0,05 & $-0,05$ & $-0,17$ & 0.02 & $-0,07$ & 0,08 & 0,19 & 0,04 & 0,06 & 0.01 \\
\hline 371 & $-0,16$ & $-0,18$ & 0,11 & $-0,18$ & $-0,16$ & 0,03 & $-0,08$ & $-0,02$ & 0,03 & 0,00 & $-0,09$ & 0,05 & 0,18 & $-0,02$ & 0,19 & $-0,05$ \\
\hline 38 (UER) & 0,16 & 0,04 & 0,14 & 0,09 & 0,11 & 0,19 & 0,18 & $-0,02$ & 0,06 & $-0,01$ & 0,02 & -0.13 & 0.13 & 0,08 & -0.15 & 0,15 \\
\hline 39 (L & 0,11 & 0,06 & 0,10 & 0,15 & $-0,16$ & 0,11 & 0,07 & $-0,11$ & $-0,14$ & $-0,01$ & 0,08 & 0,06 & 0,00 & 0,08 & $-0,04$ & 0,06 \\
\hline 40 (PrR) & 0,09 & 0,01 & 0,04 & $-0,06$ & 0,11 & 0,09 & $-0,09$ & 0,00 & 0,13 & $-0,14$ & 0,22 & 0,09 & 0.13 & $-0,03$ & $-0,04$ & $-0,15$ \\
\hline 41( & $-0,11$ & $-0,12$ & 0,12 & $-0,02$ & $-0,16$ & 0,03 & 0,02 & 0,11 & $-0,07$ & 0,09 & $-0,05$ & 0,04 & 0,05 & $-0,09$ & $-0,05$ & 0,15 \\
\hline 42 (MGR) & $-0,04$ & $-0,14$ & 0,06 & $-0,14$ & $-0,04$ & $-0,06$ & 0,08 & $-0,04$ & 0,02 & 0,04 & 0,15 & $-0,10$ & 0,12 & 0,00 & $-0,15$ & $-0,16$ \\
\hline 43 (CzR) & 0,15 & 0,10 & 0,11 & 0,26 & 0,13 & $-0,08$ & $-0,03$ & $-0,09$ & 0,05 & $-0,13$ & 0,01 & 0,01 & 0,04 & $-0,04$ & $-0,01$ & $-0,14$ \\
\hline 44 (FR) & $-0,05$ & 0,03 & $-0,03$ & $-0,02$ & $-0,06$ & $-0,12$ & $-0,09$ & $-0,06$ & 0,06 & $-0,13$ & $-0,07$ & 0,08 & $-0,06$ & 0,05 & 0,05 & 0,01 \\
\hline 45 (AçR) & $-0,04$ & $-0,02$ & $-0,06$ & 0,03 & 0,01 & $-0,02$ & 0,10 & 0,11 & $-0,08$ & $-0,04$ & $-0,02$ & 0,02 & $-0,04$ & 0,10 & 0,08 & 0,03 \\
\hline 46 (UR) & 0,14 & 0,04 & 0,24 & 0,09 & $-0,08$ & 0,12 & 0,04 & $-0,13$ & $-0,10$ & 0,04 & 0,03 & -0.02 & 0.01 & 0.11 & $-0,01$ & $-0,02$ \\
\hline
\end{tabular}


Tabela 39.2 Estimativas das correlações ambientais entre os descritores contínuos. Continuação.

\begin{tabular}{|c|c|c|c|c|c|c|c|c|c|c|c|c|c|c|c|}
\hline & 32 & 33 & 34 & 35 & 36 & 37 & 38 & 39 & 40 & 41 & 42 & 43 & 44 & 45 & \\
\hline & & & & & & & & & & & & & & & \\
\hline & & & & & & & & & & & & & & 0.02 & \\
\hline & & .00 & $-0,08$ & -0.08 & & & & & 0,04 & & & & & $-0,06$ & 0.2 \\
\hline & & -0.06 & 0.10 & 0.14 & -0.32 & & 09 & 0.15 & -0.06 & & & 0.26 & & .03 & 0.0 \\
\hline & & 0,02 & 0,14 & & & & & $-0,16$ & & & & & & 01 & -0.0 \\
\hline & & & & & & & & & & & & & & & 0,1 \\
\hline & & & & & & & & & & & & & & 10 & 0,0 \\
\hline & & -0 , & 0,09 & 0,16 & & & & & & & & & & 11 & $-0,13$ \\
\hline & & $-0,15$ & 0,08 & $-0,02$ & $-0,17$ & 0,03 & & $-0,14$ & 0,13 & & 02 & 0,05 & 0,06 & $-0,08$ & $-0,10$ \\
\hline & & & & & & & & $-0,01$ & $-0,14$ & & & & & $-0,04$ & 0,0 \\
\hline & & & & & $-0,07$ & & & & & & & & & & 0,03 \\
\hline & & & -0 , & & & & & & & & & & & 02 & $-0,02$ \\
\hline & & & & & & & & & & & & & & & 0,01 \\
\hline & & & & & & & & & -0 , & & & & & 10 & 0,1 \\
\hline & & & & & & & & & & & & & & & -0.0 \\
\hline & & -0 & & 0,07 & 0,01 & & & 0,06 & & & & & 01 & .03 & $-0,02$ \\
\hline & & & & $-0,21$ & & & & & & & & & & 23 & 0,1 \\
\hline & & & -0 & $-0,0$ & & & & & & -0 , & & & & 00 & $-0,1$ \\
\hline & & -0, & & & & & & & $-0,03$ & -0 & & $-0,06$ & & 20 & $-0,1$ \\
\hline & & -0 & & & & & & & & & & & & 27 & -0.1 \\
\hline & & & & & & & & & & & & & 0 & 05 & 0.0 \\
\hline & & & & & & & & & & & & & $-0,03$ & & 0,0 \\
\hline & & & & $-0,02$ & $-0,01$ & & & & & & & & & & 0,2 \\
\hline & & & & & & & & 1 & -0 , & & & & & & 0,8 \\
\hline & & & & $-0,06$ & $-0,12$ & & $-0,03$ & $-0,02$ & & $-0,46$ & & 6 & 16 & & 0.0 \\
\hline & & $-0,0$ & & & & & & 0 & & & 22 & & -0 & -0 & 0,0 \\
\hline & & & & $-0,11$ & -0, & $-0,0$ & $-0,03$ & -0 , & & & & 0 & & $-0,18$ & $-0,0$ \\
\hline & & & & & & & & & & & & & & & 0,0 \\
\hline & & & & $-0,04$ & & $-0,03$ & & & & & & 0,10 & & 0,05 & 0,0 \\
\hline & $-0,23$ & 0,00 & 0,20 & 0,27 & $-0,05$ & $-0,08$ & $-0,03$ & $-0,22$ & $-0,10$ & $-0,15$ & $-0,18$ & $-0,12$ & 0,05 & 1.00 & $-0,18$ \\
\hline 46 (UR) & 0,10 & $-0,14$ & $-0,16$ & $-0,18$ & 0,05 & 0,01 & 0,23 & 0,81 & 0,00 & 0,04 & $-0,01$ & 0,08 & 0,05 & $-0,18$ & 1.0 \\
\hline
\end{tabular}


Tabela 40.1. Estimativa das variâncias genéticas, para cada desdobramento, dos descritores 15 a 25 .

\begin{tabular}{|c|c|c|c|c|c|c|c|c|c|c|c|}
\hline & 15 & 16 & 17 & 18 & 19 & 20 & 21 & 22 & 23 & 24 & 25 \\
\hline Etnovar (geral) & 1,351 & 1,301 & 0,007 & 0,177 & 0,219 & 57483,4 & 2828,0 & 3,405 & 1,693 & 0,960 & 1,009 \\
\hline Regiões (A) & 1,200 & 0,546 & 0,003 & 0,093 & 0,202 & 9932,9 & $-94,5$ & -0.073 & 0,057 & 0,047 & 0,111 \\
\hline Roças/A & 0,229 & 0,056 & 0,002 & 0,002 & 0,038 & 25867,1 & 116,7 & -1.476 & $-0,079$ & $-0,200$ & $-0,087$ \\
\hline Etnovar/R/A & 0,408 & 0,917 & 0,004 & 0,132 & 0,061 & 27653.3 & 2778,3 & 4,806 & 1,732 & 1,115 & 1,021 \\
\hline Etnovar/Al ${ }^{(1)}$ & 0,743 & 0,642 & 0.006 & 0,167 & 0,107 & 69769,8 & 3025,0 & 3,185 & 2,223 & 0,737 & 0,472 \\
\hline Roças/Al & 0,386 & $-0,018$ & 0,003 & 0,023 & 0,066 & 27422,3 & $-487,4$ & $-1,113$ & $-0,382$ & 0.041 & $-0,033$ \\
\hline Etnovar/R/Al & 0,357 & 0,660 & 0,003 & 0,144 & 0,041 & 42347,5 & 3512,4 & 4,298 & 2,605 & 0,696 & 0,505 \\
\hline Etnovar/A2 $2^{(1)}$ & $-1,623$ & 0,820 & 0,004 & 0,145 & 0,074 & 78745,2 & 2872,8 & 0,276 & 0,520 & 1,293 & 1,268 \\
\hline Roças/A2 & $-2,132$ & 0,006 & $-0,001$ & 0,014 & $-0,022$ & 52372,7 & 1142,3 & $-2,330$ & 0,234 & $-0,159$ & 0,000 \\
\hline Etnovar/R/A2 & 0,509 & 0,814 & 0,005 & 0,131 & 0,096 & 26372,5 & 1730,5 & 2.606 & 0,286 & 1,452 & 1,268 \\
\hline Etnovar/A $3^{(1)}$ & 0,628 & 2,170 & 0,005 & 0,028 & 0,112 & $-28557,5$ & 2624,2 & 8.363 & 1,699 & 0,911 & 1,789 \\
\hline Roças/A3 & 0,227 & $-0,532$ & 0,000 & $-0,043$ & 0,038 & 24436,9 & 923,0 & -5.962 & 0,650 & $-1,603$ & $-1,463$ \\
\hline Etnovar/R/A3 & 0,401 & 2,702 & 0,005 & 0,071 & 0,074 & $-52994,4$ & 1701,2 & 14,325 & 1,049 & 2,514 & 3,252 \\
\hline
\end{tabular}

A: Regiões, efeito aleatório

Al: Rio Negro - Bacia Amazônica

A2: Rio Solimões - Bacia Amazônica

A3: Litoral sul - SP

R: Roça, efeito aleatório

$\mathrm{V}$ : etnovariedades, efeito aleatório

(1): variâncias calculadas através da soma dos seus desdobramentos

obs: as variâncias em negrito, correspondem aos QM que foram significativos pelo menos a $5 \%$ de probabilidade. 
Tabela 40.2. Estimativa das variâncias genéticas, para cada desdobramento, dos descritores 26 a 37.

\begin{tabular}{|c|c|c|c|c|c|c|c|c|c|c|c|}
\hline & 26 & 28 & 29 & 30 & 31 & 32 & 33 & 34 & 35 & 36 & 37 \\
\hline Etnovar. & 2,107 & 8,652 & 1,418 & 2,086 & 12,516 & $\mathbf{0 , 0 8 8}$ & 3,901 & 6185,8 & 56,661 & 258,7 & 2,487 \\
\hline Regiões (A) & -0.076 & 3,068 & 0.024 & 0,017 & 0,442 & 0,002 & 0.024 & -56.8 & 1,788 & 10.1 & 0.051 \\
\hline Roças/A & 0,244 & $-0,677$ & $-0,022$ & 0,211 & $-1,735$ & $-0,006$ & 0,309 & 397.9 & 3,778 & 54.7 & 0,931 \\
\hline Etnovar/R/A & 1,930 & 7,400 & 1,424 & 1,882 & 13,841 & 0,093 & 3,602 & 5854,9 & 52,099 & 202,2 & 1,599 \\
\hline Etnovar/Al ${ }^{(1)}$ & 2,234 & 3,305 & 1.850 & 1,218 & 15,421 & 0,088 & 4,471 & 6821.7 & 55,129 & 362.0 & 3.607 \\
\hline Roças/A1 & 0,365 & $-0,739$ & 0,053 & 0,143 & 0,324 & 0,011 & 0,175 & 975,2 & 8.693 & 97,7 & 1,762 \\
\hline Etnovar/R/Al & 1,869 & 4,044 & 1,797 & 1,075 & 15,097 & 0,077 & 4,296 & 5846,5 & 46,436 & 264,3 & 1,845 \\
\hline Etnovar/A2 ${ }^{(1)}$ & 3,465 & 11,762 & 1,675 & 3,734 & 10,183 & 0,113 & 2,637 & +372.5 & 49,585 & 66.0 & 0,532 \\
\hline Roças/A2 & 0,876 & 1,134 & 0,628 & $-0,013$ & $-1,968$ & $-0,036$ & $-0,851$ & -+14.2 & $-0,566$ & $-22,8$ & -0.139 \\
\hline Etnovar/R/A2 & 2,589 & 10,628 & 1,047 & 3,747 & 12,151 & 0,149 & 3,488 & 4786,7 & 50,151 & 88,8 & 0,671 \\
\hline Etnovar/A3 $3^{(1)}$ & 0,143 & 9,467 & 0,308 & 2,120 & 5,503 & 0,039 & 3,970 & 7401,5 & 67,825 & 231,3 & 2.350 \\
\hline Roças/A3 & $-0,158$ & $-7,552$ & $-0,096$ & 1,197 & $-6,183$ & 0,024 & 4,021 & -1706.0 & $-22,680$ & 45,4 & $-0,626$ \\
\hline Etnovar/R/A3 & 0,301 & 17,019 & 0,404 & 0,923 & 11,686 & 0,015 & $-0,051$ & 9107,5 & 90,505 & 185,9 & 2,976 \\
\hline
\end{tabular}

A: Regiões, efeito aleatório

Al: Rio Negro - Bacia Amazônica

A2: Rio Solimões - Bacia Amazônica

A3: Litoral sul - SP

R: Roça, efeito aleatório

$\mathrm{V}$ : etnovariedades, efeito aleatório

(1): variâncias calculadas através da soma dos seus desdobramentos

obs: as variâncias em negrito, correspondem aos QM que foram significativos pelo menos a 5\% de probabilidade. 
Tabela 40.3. Estimativa das variâncias genéticas, para cada desdobramento, dos descritores 38 a 46.

\begin{tabular}{|c|c|c|c|c|c|c|c|c|c|}
\hline & 38 & 39 & 40 & 41 & 42 & 43 & 44 & 45 & 46 \\
\hline Etnovar & 7,787 & 21,487 & 0,568 & 3,132 & 0,0044 & 0,301 & 0,781 & 0,02608 & 17,508 \\
\hline Regiōes (A) & 0,446 & 5,862 & -0.069 & 0,051 & $-0,0006$ & 0,038 & 0,067 & $-0,00004$ & 4,572 \\
\hline Roças/A & $-1,825$ & 1,888 & 0,186 & 1,102 & 0.0013 & 0.061 & 0,208 & 0.00037 & 1,476 \\
\hline Etnovar/R/A & 9,192 & 16,176 & 0,439 & 2,088 & 0,0036 & 0,222 & 0,550 & 0,02576 & 13,357 \\
\hline Etnovar/Al ${ }^{(1)}$ & 11,406 & 22,555 & 0,730 & 5,032 & 0,003 & 0,422 & 0,988 & 0.021 & 19,204 \\
\hline Roças/Al & $-1,077$ & 8,313 & 0,346 & 2,395 & $-0,001$ & 0,118 & 0,394 & 0,001 & 6,326 \\
\hline Etnovar/R/Al & 12,483 & 14,242 & 0,384 & 2,637 & 0,004 & 0,304 & 0,594 & 0,020 & 12,878 \\
\hline Etnovar/A2 ${ }^{(1)}$ & 6,472 & 18,510 & 0,463 & 1,369 & 0,007 & 0,126 & 0,462 & 0.037 & 14,745 \\
\hline Roças/A2 & $-0,927$ & $-5,667$ & $-0,122$ & $-0,304$ & 0,003 & $-0,007$ & $-0,093$ & -0.006 & $-3,382$ \\
\hline Etnovar/R/A2 & 7,399 & 24,177 & 0,585 & 1,673 & 0,004 & 0,133 & 0,555 & 0,043 & 18,127 \\
\hline Etnovar/A3 ${ }^{(1)}$ & $-2,986$ & 3,752 & 0.535 & 0,475 & 0,007 & 0,109 & 0,505 & 0.024 & 1,916 \\
\hline Roças/A3 & 1,365 & 0,460 & 0,215 & 0,300 & 0,004 & 0,087 & 0,225 & 0,018 & 0,113 \\
\hline Etnovar/R/A3 & $-4,351$ & 3,292 & 0,320 & 0,175 & 0,003 & 0,022 & 0,280 & 0.006 & 1,803 \\
\hline
\end{tabular}

\section{A: Regiões, efeito aleatório}

A 1: Rio Negro - Bacia Amazônica

A2: Rio Solimões - Bacia Amazônica

A3: Litoral sul - SP

R: Roça, efeito aleatório

$\mathrm{V}$ : etnovariedades, efeito aleatório

${ }^{(1)}$ : variâncias calculadas através da soma dos seus desdobramentos

obs: as variâncias em negrito, correspondem aos QM que foram significativos pelo menos a $5 \%$ de probabilidade. 
Tabela 41. Distribuição das variâncias genéticas em porcentagem entre regiões (A), entre roças dentro de regiões (R/A) e entre etnovariedades dentro de roças dentro de regiōes (V/R/A).

\begin{tabular}{|c|c|c|c|c|c|c|c|c|c|}
\hline & 15 & 16 & 17 & 18 & 19 & 20 & 21 & 22 & 23 \\
\hline $\begin{array}{l}\text { Regiōes (A) } \\
\text { Roças/A } \\
\text { Etnovar/R/A }\end{array}$ & $\begin{array}{l}65,33 \% \\
12,45 \% \\
22,22 \%\end{array}$ & $\begin{array}{r}35,94 \% \\
3,69 \% \\
60,37 \%\end{array}$ & $\begin{array}{c}34,85 \% \\
18,91 \% \\
46,24 \%\end{array}$ & $\begin{array}{c}40,82 \% \\
0,88 \% \\
58.30 \%\end{array}$ & $\begin{array}{l}67,05 \% \\
12,65 \% \\
20,29 \%\end{array}$ & $\begin{array}{l}15,65 \% \\
40,77 \% \\
43,58 \%\end{array}$ & $\begin{array}{r}0.00 \% \\
4.03 \% \\
95,97 \%\end{array}$ & $\begin{array}{r}0,00 \% \\
0,00 \% \\
100,00 \%\end{array}$ & $\begin{array}{r}3,16 \% \\
0.00 \% \\
96,84 \%\end{array}$ \\
\hline & 24 & 25 & 26 & 28 & 29 & 30 & 31 & 32 & 33 \\
\hline $\begin{array}{l}\text { Regiōes (A) } \\
\text { Roças/A } \\
\text { Etnovar/R/A }\end{array}$ & $\begin{array}{r}4,01 \% \\
0,00 \% \\
95,99 \%\end{array}$ & $\begin{array}{r}9,83 \% \\
0,00 \% \\
90,17 \%\end{array}$ & $\begin{array}{r}0,00 \% \\
11,21 \% \\
88,79 \%\end{array}$ & $\begin{array}{r}29,31 \% \\
0,00 \% \\
70,69 \%\end{array}$ & $\begin{array}{r}1,62 \% \\
0,00 \% \\
98,38 \%\end{array}$ & $\begin{array}{r}0,80 \% \\
9,99 \% \\
89,21 \%\end{array}$ & $\begin{array}{r}3,09 \% \\
0.00 \% \\
96,91 \%\end{array}$ & $\begin{array}{r}2,01 \% \\
0,00 \% \\
97,99 \%\end{array}$ & $\begin{array}{r}0.62 \% \\
7.86 \% \\
91.52 \%\end{array}$ \\
\hline & 34 & 35 & 36 & 37 & 38 & 39 & 40 & 41 & 42 \\
\hline Regiões (A) & $0,00 \%$ & $3,10 \%$ & $3,78 \%$ & $1,99 \%$ & $4,63 \%$ & $24.50 \%$ & $0.00 \%$ & $1,57 \%$ & $0,00 \%$ \\
\hline Roças/A & $6,36 \%$ & $6,55 \%$ & $20,50 \%$ & $36,07 \%$ & $0,00 \%$ & $7,89 \%$ & $29.76 \%$ & $34,01 \%$ & $25.87 \%$ \\
\hline Etnovar/R/A & $93,64 \%$ & $90,35 \%$ & $75.72 \%$ & $61,94 \%$ & $95,37 \%$ & $67,61 \%$ & $70.24 \%$ & $64,42 \%$ & $74,13 \%$ \\
\hline
\end{tabular}

\begin{tabular}{lcrrrrrrrr}
\hline & 43 & 44 & 45 & 46 & $\begin{array}{r}\text { Média } \\
(\mathbf{1 5} \text { a 19) }\end{array}$ & $\begin{array}{r}\text { Média } \\
(\mathbf{2 0} \text { a 26) }\end{array}$ & $\begin{array}{r}\text { Média } \\
(\mathbf{2 8} \text { a 33) }\end{array}$ & $\begin{array}{r}\text { Média } \\
\text { (34 a 46) }\end{array}$ & $\begin{array}{c}\text { Média } \\
\text { (geral) }\end{array}$ \\
\hline & & & & & & & & & \\
Regiões (A) & $11,88 \%$ & $8,13 \%$ & $0,00 \%$ & $23,56 \%$ & $\mathbf{4 8 , 8 0 \%}$ & $\mathbf{4 , 6 6 \%}$ & $\mathbf{6 , 2 4 \%}$ & $\mathbf{6 , 3 9 \%}$ & $\mathbf{1 2 , 8 1 \%}$ \\
Roças/A & $18,92 \%$ & $25,21 \%$ & $1,42 \%$ & $7,61 \%$ & $\mathbf{9 , 7 2 \%}$ & $\mathbf{8 , 0 0 \%}$ & $\mathbf{2 , 9 8 \%}$ & $\mathbf{1 6 , 9 4 \%}$ & $\mathbf{1 1 , 0 5 \%}$ \\
Etnovar/R/A & $69,20 \%$ & $66,66 \%$ & $98,58 \%$ & $68,83 \%$ & $\mathbf{4 1 , 4 9 \%}$ & $\mathbf{8 7 , 3 3 \%}$ & $\mathbf{9 0 , 7 8 \%}$ & $\mathbf{7 6 , 6 7 \%}$ & $\mathbf{7 6 , 1 3 \%}$ \\
\hline
\end{tabular}
A: Regiões
R: Roças
V: Etnovariedade

obs: para o cálculo das porcentagens, considerou-se os valores negativos como variância genética zero. 
Tabela 42. Distribuição da variância genética dentro de roças, em porcentagem para cada região separadamente, para os descritores 15 a 46 e a média do conjunto.

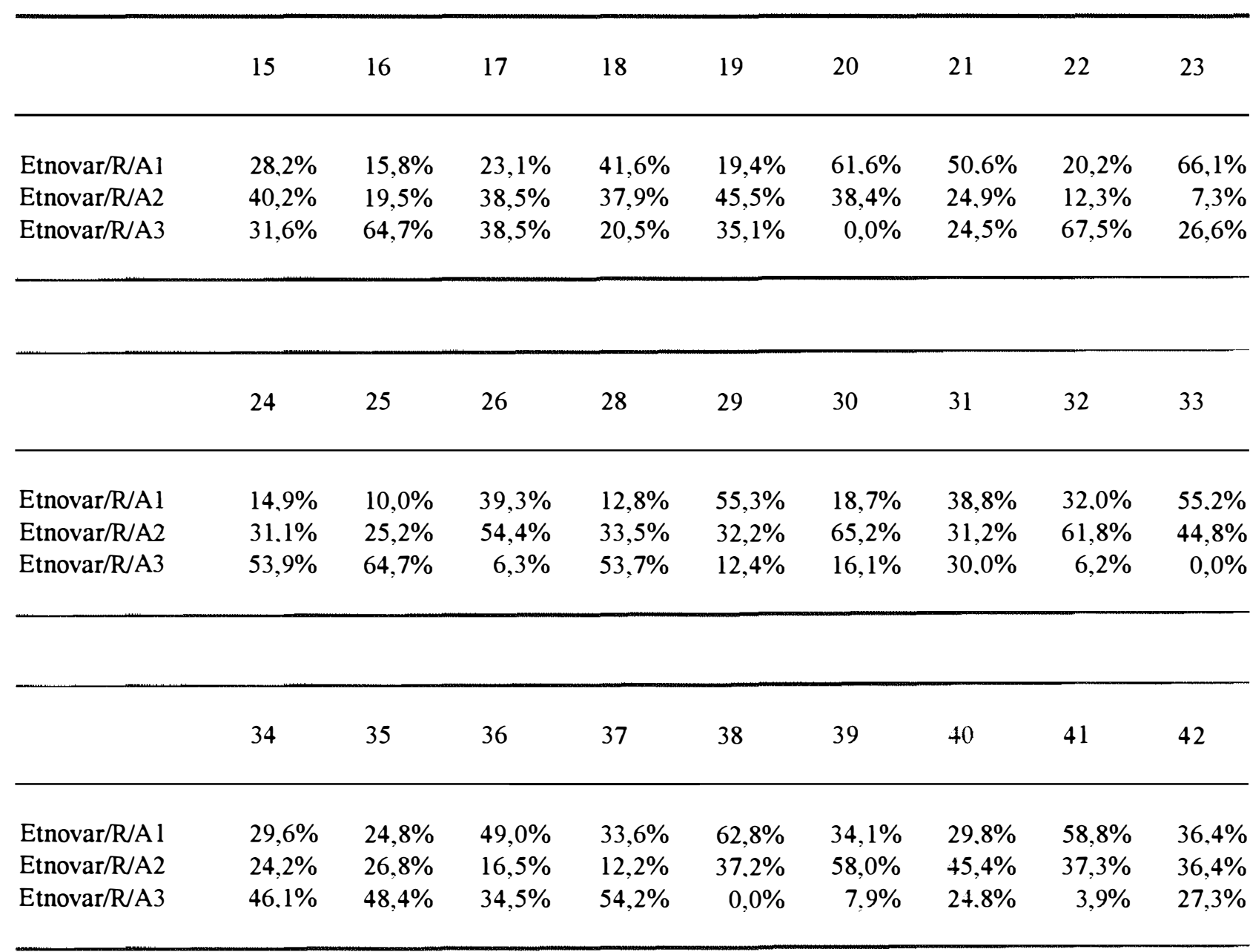

\begin{tabular}{lrrrrrrrrr}
\hline & 43 & 44 & 45 & 46 & $\begin{array}{c}\text { Média } \\
\text { (15 a 19) }\end{array}$ & $\begin{array}{c}\text { Média } \\
\text { (20 a 26) }\end{array}$ & $\begin{array}{c}\text { Média } \\
\text { (28 a 33) }\end{array}$ & $\begin{array}{c}\text { Média } \\
\text { (34 a 46) }\end{array}$ & $\begin{array}{c}\text { Média } \\
\text { (geral) }\end{array}$ \\
\hline & & & & & & & & & \\
Etnovar/R/A1 & $66.2 \%$ & $41,6 \%$ & $29,0 \%$ & $39,3 \%$ & $\mathbf{2 5 , 6 2 \%}$ & $\mathbf{3 7 , 5 5 \%}$ & $\mathbf{3 5 , 4 5 \%}$ & $\mathbf{4 1 , 1 5 \%}$ & $\mathbf{3 6 , 7 3 \%}$ \\
Etnovar/R/A2 & $29,0 \%$ & $38,8 \%$ & $62,3 \%$ & $55,3 \%$ & $\mathbf{3 6 , 3 0 \%}$ & $\mathbf{2 7 , 6 6 \%}$ & $\mathbf{4 4 , 8 1 \%}$ & $\mathbf{3 6 , 8 7 \%}$ & $\mathbf{3 6 , 2 4 \%}$ \\
Etnovar/R/A3 & $4,8 \%$ & $19,6 \%$ & $8,7 \%$ & $5,5 \%$ & $\mathbf{3 8 , 0 8 \%}$ & $\mathbf{3 4 , 8 0 \%}$ & $\mathbf{1 9 , 7 4 \%}$ & $\mathbf{2 1 , 9 7 \%}$ & $\mathbf{2 7 , 0 4 \%}$ \\
\hline
\end{tabular}

R: roça

Al: Rio Negro - Bacia Amazônica

A2: Rio Solimões - Bacia Amazônica

A3: Litoral sul - SP

obs: para o cálculo das porcentagens, considerou-se os valores negativos como variância genética zero. 
Tabela 43. Distribuição da variância genética, em porcentagem dentro de cada região, considerando as variáveis 15 a 46 e a média do conjunto.

\begin{tabular}{|c|c|c|c|c|c|c|c|c|c|}
\hline & 15 & 16 & 17 & 18 & 19 & 20 & 21 & 22 & 23 \\
\hline Etnovar/Al & $54,19 \%$ & $17,68 \%$ & $40,00 \%$ & $49,12 \%$ & $36,52 \%$ & $46,98 \%$ & $35,50 \%$ & $26,94 \%$ & $50.05 \%$ \\
\hline Etnovar/A2 & $0,00 \%$ & $22,58 \%$ & $26,67 \%$ & $42,65 \%$ & $25,26 \%$ & $53,02 \%$ & $33,71 \%$ & $2,33 \%$ & $11,71 \%$ \\
\hline \multirow[t]{2}{*}{ Etnovar/A3 } & $45,81 \%$ & $59,75 \%$ & $33,33 \%$ & $8,24 \%$ & $38,23 \%$ & $0,00 \%$ & $30,79 \%$ & $70,73 \%$ & $38,25 \%$ \\
\hline & 24 & 25 & 26 & 28 & 29 & 30 & 31 & 32 & 33 \\
\hline Etnovar/Al & $25,06 \%$ & $13,37 \%$ & $38,24 \%$ & $13,47 \%$ & $48,27 \%$ & $17,22 \%$ & $49,57 \%$ & $36,67 \%$ & $40,36 \%$ \\
\hline Etnovar/A2 & $43,96 \%$ & $35,93 \%$ & $59,31 \%$ & $47,94 \%$ & $43,70 \%$ & $52,80 \%$ & $32,74 \%$ & $47,08 \%$ & $23,80 \%$ \\
\hline \multirow[t]{2}{*}{ Etnovar/A3 } & $30,98 \%$ & $50,69 \%$ & $2,45 \%$ & $38,59 \%$ & $8,03 \%$ & $29,98 \%$ & $17,69 \%$ & $16,25 \%$ & $35,84 \%$ \\
\hline & 34 & 35 & 36 & 37 & 38 & 39 & 40 & 41 & 42 \\
\hline Etnovar/Al & $36,68 \%$ & $31,95 \%$ & $54,91 \%$ & $55,59 \%$ & $63,80 \%$ & $50,33 \%$ & $42.25 \%$ & $73,18 \%$ & $17.65 \%$ \\
\hline Etnovar/A2 & $23.51 \%$ & $28,74 \%$ & $10,01 \%$ & $8,20 \%$ & $36.20 \%$ & $41,30 \%$ & $26,79 \%$ & $19.91 \%$ & $41.18 \%$ \\
\hline Etnovar/A3 & $39,80 \%$ & $39,31 \%$ & $35,09 \%$ & $36,22 \%$ & $0,00 \%$ & $8,37 \%$ & $30,96 \%$ & $6,91 \%$ & $41,18 \%$ \\
\hline
\end{tabular}

\begin{tabular}{lrrrrr}
\hline & 43 & 44 & 45 & 46 & Média \\
& & & & & \\
\hline & & & & & \\
Etnovar/A1 & $64,23 \%$ & $50,54 \%$ & $25,61 \%$ & $53,55 \%$ & $\mathbf{4 0 , 6 3 \%}$ \\
Etnovar/A2 & $19,18 \%$ & $23,63 \%$ & $45,12 \%$ & $41,11 \%$ & $\mathbf{3 1 , 2 9 \%}$ \\
Etnovar/A3 & $16,59 \%$ & $25,83 \%$ & $29,27 \%$ & $5,34 \%$ & $\mathbf{2 8 , 0 8 \%}$ \\
\hline
\end{tabular}

Etnovar/A1: porcentagem da variância genética total dentro da região do Rio Negro Etnovar/A2: porcentagem da variância genética total dentro da região do Rio Solimões Etnovar/A3: porcentagem da variância genética total dentro da região do litoral sul do Est de São Paulo obs: para o cálculo das porcentagens, considerou-se os valores negativos como variância genética zero 
Tabela 44. Estimativas dos autovalores da análise por variáveis canônicas.

\begin{tabular}{|c|c|c|c|}
\hline Var. Can. & Raiz & Raiz (\%) & Var. Acum. (\%) \\
\hline $\mathrm{VCl}$ & 141,6325 & 33.23 & 33.23 \\
\hline VC2 & 105,1234 & 24,66 & 57.89 \\
\hline VC3 & 50,2359 & 11.79 & 69.68 \\
\hline VC4 & 40,2178 & 9,44 & 79.11 \\
\hline VC5 & 21,0934 & 4,95 & 84.06 \\
\hline VC6 & 19,2718 & 4,52 & 88,58 \\
\hline VC7 & 10,9687 & 2,57 & 91,16 \\
\hline VC8 & 7,1998 & 1,69 & 92.85 \\
\hline VC9 & 5,7027 & 1,34 & 94,18 \\
\hline $\mathrm{VC} 10$ & 4,1174 & 0,97 & 95,15 \\
\hline $\mathrm{VC} 11$ & 3,2989 & 0,77 & 95,92 \\
\hline $\mathrm{VC} 12$ & 2,5378 & 0,60 & 96,52 \\
\hline VC13 & 2,3324 & 0,55 & 97,07 \\
\hline $\mathrm{VCl} 4$ & 1,8673 & 0,44 & 97.51 \\
\hline $\mathrm{VC} 15$ & 1,7040 & 0,40 & 97,91 \\
\hline $\mathrm{VCl}$ & 1,3874 & 0,33 & 98,23 \\
\hline $\mathrm{VCl} 17$ & 1,2963 & 0,30 & 98,53 \\
\hline VC18 & 1,0794 & 0,25 & 98,79 \\
\hline VC19 & 0,8663 & 0,20 & 98,99 \\
\hline VC20 & 0,7716 & 0,18 & 99,17 \\
\hline VC21 & 0,6140 & 0.14 & 99,32 \\
\hline VC22 & 0,5970 & 0,14 & 99,46 \\
\hline $\mathrm{VC} 23$ & 0,4831 & 0,11 & 99,57 \\
\hline $\mathrm{VC} 24$ & 0,3988 & 0,09 & 99,66 \\
\hline $\mathrm{VC} 25$ & 0,3689 & 0,09 & 99,75 \\
\hline VC26 & 0.2971 & 0,07 & 99,82 \\
\hline VC27 & 0,2249 & 0,05 & 99,87 \\
\hline VC28 & 0,2068 & 0,05 & 99,92 \\
\hline VC29 & 0,1605 & 0,04 & 99,96 \\
\hline VC30 & 0,0988 & 0,02 & 99,98 \\
\hline VC31 & 0,0775 & 0,02 & 100,00 \\
\hline
\end{tabular}


Tabela 45. Distância Generalizada de Mahalanobis entre as etnovariedades.

\begin{tabular}{|c|c|c|c|c|c|c|c|c|c|c|c|}
\hline Etnov. & DG38 & DG39 & DG40 & DG41 & DG42 & DG43 & DG44 & DG45 & DG46 & DG47 & DG48 \\
\hline DG38 & 0.00 & 580.06 & 1123.03 & 461.88 & 801.92 & 1318.73 & 1234.09 & 1450.06 & 1670.86 & 821.27 & 754.30 \\
\hline DG39 & 580.06 & 0.00 & 332.08 & 195.83 & 461.39 & ๓35.98 & 848.68 & 575.73 & 1146.81 & 337.18 & 422.87 \\
\hline DG40 & 1123.03 & 332.08 & 0.00 & 220.81 & 461.73 & 651.44 & 755.37 & 992.62 & 762.06 & 360.49 & 381.44 \\
\hline DG41 & 461.88 & 195.83 & 220.81 & 0.00 & 402.40 & 725.03 & 797.56 & 868.78 & 808.49 & 384.48 & 218.19 \\
\hline DG42 & 801.92 & 461.39 & 461.73 & 402.40 & 0.00 & 265.33 & 469.00 & 1081.18 & 1008.67 & 556.40 & 386.17 \\
\hline DG43 & 1318.73 & ๔5.98 & 651.44 & $725 . ธ 3$ & 265.33 & 0.00 & 351.60 & 1124.77 & 1137.78 & 525.ఝ3 & 592.52 \\
\hline DG44 & 1234.09 & 848.68 & 755.37 & 797.56 & 469.00 & 351.60 & 0.00 & 1007.23 & & & \\
\hline DG45 & 1459.06 & 575.73 & 992.62 & 868.78 & 1081.18 & 1124.77 & 1607.23 & 0.00 & 1622.44 & 1307.75 & 999.09 \\
\hline DG46 & 1670.86 & 1146.81 & 762.06 & 808.49 & 1008.67 & 1137.78 & 1038.49 & 1622.44 & 0.00 & 878.15 & 484.13 \\
\hline DG47 & 821.27 & 337.18 & 360.49 & 384.48 & 556.40 & & 389.20 & 1307.75 & 878.15 & 0.00 & 505.03 \\
\hline DG48 & 54.30 & 422.87 & 381.44 & 218.19 & 386.17 & & 844.42 & 990.00 & 484.13 & 505.03 & 0.00 \\
\hline DG49 & 990.55 & 322.15 & 297.73 & 257.92 & 565.84 & 605.49 & 1031.20 & 550.85 & 643.22 & 07.82 & 224.44 \\
\hline DG50 & 1350.50 & 392.22 & 123.49 & 425.01 & 546.56 & 699.93 & & 886.75 & 851.03 & & 556.60 \\
\hline DG51 & 1700.02 & 455.51 & 204.79 & 589.42 & 777.44 & 689.81 & 827.87 & 873.50 & 740.76 & 47.09 & 624.01 \\
\hline DG52 & 954.02 & 319.26 & 161.28 & 296.04 & 376.21 & ळ1.67 & 867.ஐ3 & 927.53 & 689.39 & 30.10 & 288.92 \\
\hline DG54 & 1595.75 & 1241.92 & 583.47 & $676 . ๘ 3$ & 1058.54 & 1355.10 & 1267.ఝ3 & 1996.53 & & & 527.94 \\
\hline DG55 & 736.72 & 619.06 & 400.57 & 254.92 & 406.94 & 723.07 & 615.16 & 1253.23 & 373.09 & & 259.08 \\
\hline DG56 & 1445.ఝ & 334.49 & & 533.02 & & 525.65 & & 515.58 & & & \\
\hline DG58 & 1675.56 & 475.32 & 325.62 & 556.35 & 721 & 676.57 & 124 & 76.08 & & .12 & 507.75 \\
\hline DG59 & 1402.20 & 431.04 & 152.91 & 412.91 & 591 & ळ7.51 & & 909.73 & & 77.60 & 371.60 \\
\hline DG60 & 30.61 & 1011.44 & 396.97 & 858.66 & 66 & 618.52 & 12 & 1600.86 & 533.32 & & 679.66 \\
\hline DG61 & 54.94 & 504.37 & 997.69 & 781.86 & & & & 5.90 & & & 777.09 \\
\hline G62 & 768.02 & 262.59 & 284.93 & 266.12 & 367.37 & 518.82 & & 841.02 & 1111.38 & & \\
\hline DG65 & 378.96 & 298.89 & 722.21 & 427.19 & 607.77 & 976.65 & 1058.04 & 798.30 & 1545.27 & 12.95 & 796.70 \\
\hline DG67 & 560.52 & 90.41 & 474.76 & 363 & 527.81 & 739.71 & 5.52 & 843.19 & & & 643.66 \\
\hline DG68 & 1097.37 & 208.47 & 301.95 & 385.41 & 34 & 663.60 & 1095.40 & 403.55 & 0.58 & 3.87 & 429.94 \\
\hline DG69 & 76.43 & 278.85 & 0.47 & 229.92 & & 354.99 & & 17.85 & & 26.81 & 213.30 \\
\hline DG70 & 843.04 & 529.01 & 375.73 & 351.42 & 502.03 & 840.14 & 721.40 & 1036.65 & 407.81 & .46 & 347.95 \\
\hline G71 & 4997.06 & 4515.76 & 3383.29 & 3543.27 & 3910.98 & 3916.59 & 3653.04 & 5287.85 & 1370.39 & 3575.31 & 2663.55 \\
\hline G73 & 41.98 & 1562.24 & 1088.00 & 1036.96 & 976.51 & 5.21 & & 6.34 & & .53 & $\pi 73.09$ \\
\hline DG111 & 29.44 & 893.70 & 619.40 & 1204.85 & 121 & $10 x$ & 101 & 1342.88 & 148 & .48 & 1312.27 \\
\hline $\mathrm{G} 112$ & 38.89 & & & & & & & 4.70 & & & 411.67 \\
\hline DG113 & & 393.91 & 324.70 & 522.70 & & 5.01 & & 44.83 & & & 560.28 \\
\hline G1 & & & & & & & & 24.12 & & & \\
\hline DG115 & 88.00 & 989.41 & 689.74 & & 771 & & 70.98 & .93 & & & 449.01 \\
\hline DG116 & 1057.45 & 805.68 & 849.41 & 790. & 279. & 387.56 & & & 767.58 & & 511.11 \\
\hline $\mathrm{DGl}$ & 438.44 & & & & & & & & & & 449.71 \\
\hline DG118 & 1490.61 & 527.60 & 501.26 & & & 860.19 & 116 & 55.22 & 2023.82 & 28.70 & 1191.24 \\
\hline & & & & & & 4.19 & & & & & 458.82 \\
\hline G1 & 18.75 & & 346.62 & 360 & & 460.99 & & 9.02 & 1254.09 & & 381.25 \\
\hline DG1 & 47.95 & 390.70 & 463.43 & & & 240.49 & & 866.74 & & 568.01 & 230.34 \\
\hline DGl & & 1796.54 & & & & 2273.39 & & & & & 1343.72 \\
\hline DG123 & 95.14 & 503.56 & 1.19 & 533.27 & & 680.13 & 654.96 & 942.94 & 541.59 & 23.58 & 543.90 \\
\hline & & & & & & & & & & & \\
\hline DG1 & & & & 3 & & 32.68 & & & & & 289.92 \\
\hline DG1 & 24.94 & & & & 374.57 & 257.53 & & & & & 504.07 \\
\hline & & & & & & & & & & & 739.96 \\
\hline DG128 & 581.77 & 744.93 & 790.16 & & 777.46 & 1254.81 & 828.64 & 1751.20 & 883.81 & 82.50 & 699.66 \\
\hline & & & & & & & & & & & \\
\hline DG1 & & & & & & & & 1075.94 & 1194 & & 490.80 \\
\hline & 583.64 & 885.70 & 1202.46 & 884.19 & 960.94 & 1576.09 & 1375.72 & 1729.77 & & & 928.90 \\
\hline & & & & & & & & & & & 847.23 \\
\hline DG133 & 738.92 & 304.98 & 4.22 & $401 . C$ & 314. & 2.89 & 865.39 & $\propto 88.01$ & 1156.25 & 666.19 & 392.56 \\
\hline & & & & & & & & & & & \\
\hline DG138 & 2119.38 & 945.06 & & 816.03 & 994.109 & 832.31 & 913.00 & 1283.47 & 562.74 & 726.83 & 723.82 \\
\hline MANT & 1629.12 & 427.82 & 425.60 & 670.90 & 712.70 & 641.52 & 1200.78 & 680.86 & 1550.37 & 847.53 & 817.78 \\
\hline
\end{tabular}


Tabela 45. Distância Generalizada de Mahalanobis entre as etnovariedades. Continuação.

\begin{tabular}{|c|c|c|c|c|c|c|c|c|c|c|c|}
\hline & DG49 & DG50 & DG51 & DG52 & DG54 & DG55 & DG56 & DG58 & DG59 & DG60 & DG61 \\
\hline DG38 & 993.55 & 1350.50 & 1700.02 & 954.02 & 1595.75 & 736.72 & 1445.ஐ & 1675.56 & 1402.20 & 2030.61 & 1254.94 \\
\hline DG39 & 322.15 & 392.22 & 455.51 & 319.26 & 1241.92 & 619.06 & 334.49 & 475.32 & 431.04 & 1011.44 & 504.37 \\
\hline DG40 & 297.73 & 123.49 & 204.79 & 161.28 & 583.47 & 409.57 & 313.27 & 325.62 & 152.91 & 396.97 & 997.69 \\
\hline DG41 & 257.92 & 425.01 & 589.42 & 296.04 & 676.ஐ3 & 254.92 & 533.02 & 556.35 & 412.91 & 858.66 & 781.86 \\
\hline DG42 & 565.84 & 546.56 & 777.44 & 376.21 & 1058.54 & 496.94 & 586.91 & 721.11 & 591.72 & 714.66 & 970.85 \\
\hline DG43 & 695.49 & 699.93 & 689.81 & $\infty 1.67$ & 1355.10 & 723.07 & 525.65 & 676.57 & 657.51 & 618.52 & 1143.90 \\
\hline DG44 & 1031.20 & 851.05 & 827.87 & 867.ஐ & 1267.ஐ3 & 615.16 & 1044.13 & 1243.22 & 878.80 & 588.12 & 2030.32 \\
\hline DG45 & 550.85 & 886.75 & 873.50 & 927.53 & 1995.53 & 1253.23 & 515.58 & 676.08 & 900.73 & 1603.86 & 805.90 \\
\hline DG46 & 643.22 & 851.03 & 740.76 & 689.39 & 423.58 & 373.09 & 12ฒ3.27 & 920.05 & 491.78 & 533.32 & 2041.48 \\
\hline DG47 & 607.82 & 483.53 & 447.09 & 390.10 & 967.11 & 440.91 & 681.34 & $\pi 72.12$ & 477.60 & 601.48 & 1299.01 \\
\hline DG48 & 224.44 & 556.60 & 624.01 & 288.92 & 527.94 & 259.08 & 640.85 & 507.75 & 371.60 & 679.66 & 777.00 \\
\hline DG49 & 0.00 & 307.75 & 391.32 & 276.75 & $\sigma 23.64$ & 407.76 & 341.27 & 236.91 & 195.73 & 726.30 & 694.67 \\
\hline DG50 & 307.75 & 0.00 & 172.71 & 146.07 & 711.67 & 581.52 & 341.00 & 347.69 & 117.28 & 440.37 & 1129.81 \\
\hline DG51 & 391.32 & 172.71 & 0.00 & 336.04 & 892.54 & 718.79 & 303.88 & 272.08 & 114.43 & 310.61 & 1204.93 \\
\hline DG52 & 276.75 & 146.07 & 336.04 & 0.00 & 655.21 & 399.02 & & 414.51 & 180.53 & 529.78 & 886.10 \\
\hline DG54 & 623.64 & 711.67 & 892.54 & 65.21 & 0.00 & 386.89 & 1277.67 & 949.02 & 523.59 & 670.54 & 2063.55 \\
\hline DG55 & 407.76 & 581.52 & 718.79 & 390.02 & 386.89 & 0.00 & 879.32 & 800.50 & & & 1486.87 \\
\hline DG56 & 341.27 & 341.00 & 303.88 & 431.65 & 1277.67 & 879.32 & 0.00 & 161.66 & 344.08 & 786.45 & 582.37 \\
\hline DG58 & 236.91 & 347.69 & 272.08 & 414.51 & 949.02 & 800.50 & 161.66 & 0.00 & 214.26 & $\varpi 4.12$ & 611.49 \\
\hline DG59 & 195.73 & 117.28 & 114.43 & 180.53 & 523.59 & 462.08 & 344.08 & 214.26 & 0.00 & 309.93 & 1063.36 \\
\hline DG60 & 726.30 & 440.37 & 310.61 & 529.78 & 670.54 & ๔0.75 & 786.45 & 654.12 & 309.93 & 0.00 & 1958.44 \\
\hline DG61 & 694.67 & 1129.81 & 1204.93 & 886.10 & 2063.55 & 1486.87 & 582.37 & 611.49 & 1063.36 & 1958.44 & 0.00 \\
\hline DG62 & 300.48 & 382.82 & 524.37 & 250.78 & 894.89 & 485.77 & 344.77 & 421.01 & 401.25 & 785.52 & 654.35 \\
\hline DG65 & 716.57 & 737.97 & 1041.44 & 536.35 & 1671.27 & 698.44 & 832.26 & 1097.27 & 20.95 & 1508.45 & 1021.46 \\
\hline DG67 & 594.73 & 504.18 & 640.92 & 395.38 & 1561.43 & 818.16 & 526.36 & 750.20 & 49.25 & 1194.32 & 672.79 \\
\hline DG68 & 160.24 & 274.35 & 276.ळ5 & 274.53 & 1063.52 & 645.19 & 175.52 & 183.99 & .87 & 788.38 & 533.13 \\
\hline DG69 & 178.14 & 268.56 & 382.11 & 162.09 & 739.21 & 311.21 & 287.39 & 274.54 & 200.60 & 508.33 & 705.12 \\
\hline DG70 & 404.07 & 399.48 & 533.21 & 243.44 & 608.60 & 260.75 & 845.46 & 829.13 & 344.57 & 528.58 & 1507.81 \\
\hline DG71 & 3274.08 & 3755.66 & 3366.51 & 3403.84 & 1750.53 & 2403.22 & 4443.84 & 3460.55 & 2891.29 & 2383.17 & 5374.38 \\
\hline DG73 & 1190.38 & 1322.24 & 1282.99 & 1103.08 & 740.26 & 396.42 & 1778.71 & 1560.61 & 1055.26 & 65.38 & 2718.54 \\
\hline DG111 & 962.66 & 410.53 & 297.19 & 711.82 & 1582.00 & 1350.01 & 757.74 & 889.21 & 540.22 & 582.29 & 1906.50 \\
\hline DG112 & 277.23 & 235.27 & 234.25 & 259.93 & 1018.26 & 744.33 & 197.97 & 195.42 & 42.88 & 678.48 & 514.05 \\
\hline DG113 & 435.52 & 232.90 & 234.09 & 244.46 & 962.36 & 571.55 & 540.01 & 579.98 & 17.91 & 428.46 & 1334.56 \\
\hline DG114 & 450.26 & 628.64 & 571.65 & 618.79 & 1181.75 & 641.99 & $304 . \varpi 3$ & 356.21 & 08.06 & ๔33.83 & 889.33 \\
\hline DG115 & 686.69 & 803.91 & 568.06 & ๔36.68 & 797.60 & 547.94 & 1007.78 & 704.68 & 465.73 & 334.54 & 1600.22 \\
\hline DG116 & 867.87 & 917.03 & 949.44 & 616.19 & 1254.23 & & 1032.25 & & & $œ 97.71$ & 1504.25 \\
\hline DG117 & 597.81 & 674.21 & 961.94 & 409.03 & 1121.65 & 376.31 & 780.99 & 963.16 & 727.64 & 1045.37 & 1098.27 \\
\hline DG118 & 744.53 & 418.32 & 590.46 & 668.12 & 1736.36 & 1253.57 & 322.95 & 692.66 & 691.40 & 1135.90 & 1143.32 \\
\hline DG119 & 410.26 & 321.37 & 573.67 & 264.97 & 860.33 & 402.14 & §ం.ஐ3 & 834.80 & 427.46 & 800.21 & 1245.19 \\
\hline DG120 & 248.73 & 414.85 & 556.96 & 385.20 & 1030.25 & 690.69 & 208.02 & 299.02 & 105.11 & 895.25 & 467.59 \\
\hline DG121 & 316.83 & 573.76 & 584.40 & 391.78 & 978.99 & 545.84 & 362.36 & 318.74 & 16.16 & 719.69 & 536.37 \\
\hline DG122 & 1979.01 & 1835.67 & 2021.10 & 1294.77 & 1570.94 & 1171.13 & 2862.64 & 2702.85 & 1771.94 & 1674.86 & 3215.98 \\
\hline DG123 & 398.49 & 239.19 & 149.48 & 294.66 & 776.58 & 442.77 & 516.05 & 472.13 & 170.12 & 264.04 & 1451.88 \\
\hline DG124 & 564.02 & 557.08 & 688.74 & 242.45 & 1092.12 & 570.35 & & 764.71 & & 851.88 & 756.22 \\
\hline DG125 & 348.91 & 341.91 & 250.17 & 207.23 & 853.28 & 442.55 & 443.35 & 329.44 & 42.03 & 422.46 & 841.67 \\
\hline DG126 & 718.98 & 688.77 & 602.20 & 700.37 & & ๔38.06 & 784.02 & 864.09 & 85.72 & 465.53 & 1558.37 \\
\hline DG12 & 870.89 & 745.78 & 919.26 & 478.51 & 1384.14 & 722.43 & 1261.35 & 1344.68 & 810.88 & 1124.05 & 1500.45 \\
\hline DG128 & 984.96 & 879.12 & 1082.47 & 503.52 & 1069.17 & 497.96 & 1500.00 & 1584.45 & 892.69 & 1070.87 & 1979.76 \\
\hline DG129 & & & & & & & & & & 730.85 & 1361.16 \\
\hline DG130 & 647.41 & 557.44 & $œ 80.46$ & 328.35 & 1371.71 & 663.34 & 669.68 & 818.76 & 596.83 & 891.90 & 871.70 \\
\hline DG131 & 1228.95 & 1211.04 & 1528.81 & 740.47 & 1644.47 & 919.76 & 1767.93 & 1899.91 & 1271.55 & 1628.55 & 1889.93 \\
\hline DG132 & & & 822.60 & & & 737.02 & 806.20 & 1133.93 & 786.56 & 1125.50 & 1336.26 \\
\hline DG133 & 503.82 & 751.10 & 837.96 & 507.92 & 1471.41 & 672.50 & 524.30 & 580.52 & 711.44 & 1129.09 & 426.49 \\
\hline DG134 & & & & & & & & 1004.16 & & 800.69 & 1317.73 \\
\hline DG138 & 483.85 & 356.75 & 212.44 & 589.03 & 550.95 & $\propto 50.92$ & 612.64 & 398.30 & 197.99 & 203.58 & 1783.91 \\
\hline MANT & 480.84 & 455.69 & 406.17 & 621.35 & 1553.48 & 1115.40 & 116.46 & 219.41 & 465.34 & 934.41 & 626.74 \\
\hline
\end{tabular}


Tabela 45. Distância Generalizada de Mahalanobis entre as etnovariedades. Continuação.

\begin{tabular}{|c|c|c|c|c|c|c|c|c|c|c|c|}
\hline & DG62 & DG65 & DG67 & DG68 & DG69 & DG70 & DG71 & DG73 & DG111 & DG112 & DG113 \\
\hline DG38 & 768.02 & 378.96 & 560.52 & 1097.37 & 876.43 & 843.04 & 4997.06 & 1641.98 & 2229.44 & 1188.89 & 1198.25 \\
\hline DG39 & 262.59 & 298.89 & 90.41 & 208.47 & 278.85 & 529.01 & 4515.76 & 1562.24 & 893.70 & 196.91 & 390.91 \\
\hline DG40 & 284.93 & 722.21 & 474.76 & 301.95 & 210.47 & 375.73 & 3383.29 & 1088.00 & 619.40 & 210.71 & 324.70 \\
\hline DG41 & 266.12 & 427.19 & 363.25 & 385.41 & 229.92 & 351.42 & 3543.27 & 1036.96 & 1204.85 & 338.42 & 522.70 \\
\hline DG42 & 367.37 & $\infty 7.77$ & 527.81 & 590.34 & 223.65 & 502.03 & 3910.98 & 976.51 & 1210.61 & 500.17 & 553.62 \\
\hline DG43 & 518.82 & 976.ळ5 & 739.71 & 663.60 & 354.99 & 840.14 & 3916.59 & 1025.21 & 1029.54 & 574.78 & 675.01 \\
\hline DG44 & 811.71 & 1058.04 & 865.52 & 1095.40 & 670.70 & 721.40 & 3653.04 & 717.95 & 1013.49 & 931.42 & 716.56 \\
\hline DG45 & 841.02 & 798.30 & 843.19 & 403.55 & 717.85 & 1036.65 & 5287.85 & 2236.34 & 1342.88 & 694.70 & 844.83 \\
\hline DG46 & 1111.38 & 1545.27 & 1496.33 & 916.58 & 706.09 & 407.81 & 1370.39 & 446.41 & 1488.54 & 1055.20 & $\$ 35.51$ \\
\hline DG47 & 369.18 & 612.95 & 335.99 & 598.87 & 406.81 & 498.46 & 3575.31 & 940.53 & 714.48 & 470.69 & 433.47 \\
\hline DG48 & 335.24 & 796.70 & 643.66 & 429.94 & 213.30 & 347.95 & 2663.55 & 773.09 & 1312.27 & 411.67 & 500.28 \\
\hline DG49 & 300.48 & 716.57 & 594.73 & 160.24 & 178.14 & 404.07 & 3274.08 & 1190.38 & 962.66 & 277.23 & 435.52 \\
\hline DG50 & 382.82 & 737.97 & 504.18 & 274.35 & 268.56 & 399.48 & 3755.66 & 1322.24 & 410.53 & 235.27 & 232.90 \\
\hline DG51 & 524.37 & 1041.44 & 640.92 & $276 . \infty 5$ & 382.11 & 533.21 & 3366.51 & 1282.99 & 297.19 & 234.25 & 234.09 \\
\hline DG52 & 250.78 & 536.35 & 395.38 & 274.53 & 162.09 & 243.44 & 3403.84 & 1103.08 & 711.82 & 259.93 & 244.46 \\
\hline DG54 & 894.89 & 1671.27 & 1561.43 & $10 \Subset 3.52$ & 739.21 & 608.60 & 1750.53 & 740.26 & 1582.09 & 1018.26 & 962.36 \\
\hline DG55 & 485.77 & 698.44 & 818.16 & 645.19 & 311.21 & 260.75 & 2403.22 & 396.42 & 1350.01 & 744.33 & 571.55 \\
\hline DG56 & 344.77 & 832.26 & 526.36 & 175.52 & 287.39 & 845.46 & 4443.84 & 1778.71 & & 197.97 & 540.01 \\
\hline DG58 & 421.01 & 1097.27 & 750.20 & 183.99 & 274.54 & 829.13 & 3460.55 & 1560.61 & 889.21 & 95.42 & 579.98 \\
\hline DG59 & 401.25 & 920.95 & 649.25 & 205.87 & 203.60 & 344.57 & 2891.29 & 1055.26 & 549.22 & 242.88 & 217.91 \\
\hline DG60 & 785.52 & 1508.45 & 1194.32 & 788.38 & 508.33 & 528.58 & 2383.17 & $\$ 55.38$ & 582.29 & 678.48 & 428.46 \\
\hline DG61 & 654.35 & 1021.46 & 672.79 & 533.13 & 705.12 & 1507.81 & 5374.38 & 2718.54 & 1906.50 & 514.05 & 1334.56 \\
\hline DG62 & 0.00 & 518.20 & 332.95 & 328.49 & 140.07 & 581.42 & 3970.66 & 1275.55 & 924.76 & 290.70 & 591.38 \\
\hline DG65 & 518.20 & 0.00 & 247.20 & 565.75 & 523.38 & 588.21 & 5296.49 & 1664.03 & 1330.74 & 747.38 & 607.44 \\
\hline DG67 & 332.95 & 247.20 & 0.00 & 396.47 & 416.62 & 681.64 & 5146.10 & 1791.10 & 883.91 & 341.25 & 508.49 \\
\hline DG68 & 328.49 & 565.75 & 396.47 & 0.00 & 194.80 & 513.97 & 3969.38 & 1517.26 & 719.24 & 185.19 & 312.ఝ3 \\
\hline DG69 & 140.07 & 523.38 & 416.62 & 194.80 & 0.00 & 350.99 & 3351.83 & 926.42 & 859.99 & 251.31 & 354.15 \\
\hline DG70 & 581.42 & 588.21 & 681.64 & 513.97 & 350.99 & 0.00 & 2936.71 & 676.84 & 895.89 & 629.85 & 186.85 \\
\hline DG71 & 3970.66 & 5295.49 & 5146.10 & 3969.38 & 3351.83 & 2936.71 & 0.00 & 1627.35 & 4712.72 & 3983.07 & 3565.30 \\
\hline DG73 & 1275.55 & 1664.ఝ & 1791.10 & 1517.26 & 926.42 & 676.84 & 1627.35 & 0.00 & 1870.37 & 1576.04 & 1062.52 \\
\hline DG111 & 924.76 & 1330.74 & 883.91 & 719.24 & 859.99 & 895.89 & 4712.72 & 1870.37 & 0.00 & 679.53 & 430.40 \\
\hline DG 112 & 299.70 & 747.38 & 341.25 & 185.19 & 251.31 & 629.85 & 3983.07 & 1576.04 & 679.53 & $0 . \infty$ & 401.84 \\
\hline DG113 & 591.38 & 607.44 & 508.49 & $312 . ๘ 3$ & 354.15 & 186.85 & 3565.30 & 1062.52 & 430.40 & 401.84 & 0.00 \\
\hline DG114 & 438.22 & 950.64 & 796.40 & 422.39 & 247.34 & 778.55 & 3570.81 & 1009.65 & 1142.55 & 450.95 & $\infty 50.73$ \\
\hline DG115 & 872.50 & 1485.77 & 1217.07 & 760.26 & 522.95 & 596.08 & 1787.17 & 494.45 & 1170.00 & 770.37 & $\varpi 01 . \varnothing 0$ \\
\hline DG116 & 774.16 & 915.53 & 844.80 & 891.96 & 518.10 & 513.74 & 3269.11 & 705.93 & 1303.77 & $8 ๘ 3.19$ & 600.49 \\
\hline DG117 & 450.27 & 307.36 & 460.59 & 577.54 & 317.74 & & 4040.59 & 959.37 & 1374.14 & 720.51 & 565.66 \\
\hline DG118 & 494.11 & $7 ळ .41$ & 518.84 & 485.68 & 586.91 & 1075.96 & 5974.10 & 2296.84 & 564.16 & 524.52 & 710.00 \\
\hline DG119 & 407.87 & 324.24 & 361.94 & 428.78 & 330.72 & 181.30 & 4156.15 & 1127.70 & 790.08 & 510.55 & 255.39 \\
\hline DG120 & 186.85 & 742.85 & 486.96 & 243.69 & 172.51 & 758.76 & 4289.45 & 1592.86 & 1017.89 & 218.49 & 679.71 \\
\hline DG121 & 320.43 & 858.41 & 590.04 & 360.86 & 172.86 & 686.48 & 3370.76 & 1131.11 & 1242.33 & 304.20 & ๒34.19 \\
\hline DG122 & 1783.29 & 1629.47 & 1009.24 & 2223.76 & 1708.84 & 906.84 & & 1197.10 & 2261.99 & 2112.90 & 1370.51 \\
\hline DG123 & 498.82 & 783.48 & 641.00 & 321.95 & 308.09 & 284.76 & 3045.55 & 836.35 & 364.03 & 446.46 & 140.86 \\
\hline DG124 & 267.88 & 476.53 & 278.80 & 503.66 & 304.48 & 458.61 & 3908.75 & 1206.66 & 1080.70 & 432.53 & 525.49 \\
\hline DG125 & 281.84 & 682.93 & 407.44 & 280.16 & 192.17 & 417.26 & 3060.93 & 917.80 & 670.62 & 244.70 & 324.04 \\
\hline DG126 & 776.24 & 1063.16 & 802.34 & 722.70 & 481.88 & 594.47 & 3305.07 & 782.64 & 875.75 & $\$ 9.09$ & 482.58 \\
\hline DG127 & 826.ஐ3 & & 474.34 & 778.42 & 726.82 & 323.89 & 4160.82 & 1250.85 & 1059.54 & 881.04 & 360.85 \\
\hline DG128 & 852.71 & 580.80 & 672.32 & 1037.58 & 770.30 & 291.33 & 3579.53 & 915.74 & 1294.ఝ & 1109.70 & 556.09 \\
\hline DG129 & 482.54 & 422.64 & 439.37 & 676.55 & 407.25 & 272.01 & 3267.66 & 713.33 & 1077.61 & 687.98 & 421.97 \\
\hline DG130 & & & & 489.43 & & & 4373.07 & 1309.66 & & 446.07 & 456.66 \\
\hline DG131 & 1052.17 & 543.21 & 776.76 & 1214.70 & 1007.60 & 502.82 & 4507.09 & 1486.82 & 1707.66 & 1371.00 & 769.09 \\
\hline DG132 & 532.64 & 160.12 & 258.60 & & $541 . ð 3$ & 459.94 & 5152.12 & 1537.79 & 881.56 & 683.33 & 422.80 \\
\hline DG133 & & 509.64 & 385.20 & & 300.81 & 734.74 & 4154.10 & 1369.33 & 1504.72 & 412.68 & 715.38 \\
\hline DG134 & ๔36.52 & 752.02 & 573.61 & 926.07 & 490.40 & 597.08 & 3710.80 & 900.33 & 1326.12 & 672.17 & 660.24 \\
\hline DG138 & 749.76 & 1541.37 & 1238.49 & 561.60 & 515.28 & 659.53 & 2516.90 & 973.96 & 556.75 & 602.97 & 510.82 \\
\hline MANT & 490.76 & 969.72 & 567.99 & 244.57 & 395.54 & 1083.54 & 4881.05 & 2029.62 & 778.72 & 266.07 & 684.51 \\
\hline
\end{tabular}


Tabela 45. Distância Generalizada de Mahalanobis entre as etnovariedades. Continuação.

\begin{tabular}{|c|c|c|c|c|c|c|c|c|c|c|c|}
\hline & DG114 & DG115 & DG116 & DG117 & DG118 & DG119 & DG120 & DG121 & DG122 & DG123 & DG124 \\
\hline DG38 & 1367.80 & 1788.00 & 1057.45 & 438.44 & 1409.61 & 550.60 & 1018.75 & 1047.95 & 1456.76 & 1395.14 & 606.42 \\
\hline DG39 & 571.30 & 989.41 & 805.68 & 459.14 & 527.60 & 304.45 & 331.64 & 390.70 & 1796.54 & 503.56 & 315.73 \\
\hline DG40 & 538.91 & 689.74 & 849.41 & 618.36 & 501.26 & 323.76 & 346.62 & 463.43 & 1606.78 & 251.19 & 380.15 \\
\hline DG41 & 598.59 & 877.16 & 790.07 & 399.50 & 796.33 & 255.69 & 360.11 & 414.99 & 1485.38 & 533.27 & 333.12 \\
\hline DG42 & 347.38 & 771.00 & 279.50 & 225.00 & 810.66 & 383.82 & 355.50 & 255.56 & 1682.84 & 687.76 & 361.87 \\
\hline DG43 & 216.93 & 689.88 & 387.56 & 545.46 & 860.19 & 764.19 & 460.99 & 240.49 & 2273.39 & 680.13 & 661.45 \\
\hline DG44 & 612.91 & 770.98 & 380.24 & 626.08 & 1164.36 & 699.69 & 966.07 & 737.33 & 1643.02 & $\$ 54.96$ & 810.92 \\
\hline DG45 & 724.12 & 1510.93 & 1333.45 & 978.49 & 855.22 & 909.47 & 699.02 & 866.74 & 3179.33 & 942.94 & 1133.94 \\
\hline DG46 & 968.65 & 312.93 & 767.58 & 975.84 & 2023.82 & 899.66 & 1254.00 & 844.45 & 1283.21 & 541.59 & 1070.47 \\
\hline DG47 & 709.83 & 678.42 & 602.79 & 551.76 & 828.70 & 431.90 & 675.39 & 568.01 & 1163.66 & 353.58 & 345.23 \\
\hline DG48 & 532.51 & 449.01 & 511.11 & 449.71 & 1191.24 & 458.82 & 381.25 & 230.34 & 1343.72 & 543.99 & 344.09 \\
\hline DG49 & 450.26 & 686.69 & 867.87 & 597.81 & 744.53 & 410.26 & 248.73 & 316.83 & 1979.01 & 398.49 & 564.02 \\
\hline DG50 & 628.64 & 803.91 & 917.03 & 674.21 & 418.32 & 321.37 & 414.85 & 573.76 & 1835.67 & 239.19 & 557.08 \\
\hline DG51 & 571.65 & 568.06 & 949.44 & 961.94 & 590.46 & 573.67 & 556.96 & 584.40 & 2021.10 & 149.48 & $\propto 88.74$ \\
\hline DG52 & 618.79 & ๗36.68 & 616.19 & 409.03 & 668.12 & 264.97 & 385.20 & 391.78 & 1294.77 & 294.66 & 242.45 \\
\hline DG54 & 1181.75 & 797.69 & 1254.23 & 1121.65 & 1736.36 & 860.33 & 1030.25 & 978.99 & 1570.94 & 776.58 & 1092.12 \\
\hline DG55 & 641.99 & 547.94 & 595.53 & 376.31 & 1258.57 & 402.14 & 690.69 & 545.84 & 1171.13 & 442.77 & 570.35 \\
\hline DG56 & 304.63 & 1007.78 & 1032.25 & 780.99 & 322.95 & œం.ఝో & 208.02 & 362.36 & 2862.64 & 516.05 & 655.39 \\
\hline DG58 & 356.21 & 704.68 & 1098.16 & 963.16 & 192.66 & 834.80 & 290.02 & 318.74 & 2702.85 & 472.13 & 64.71 \\
\hline DG59 & 508.06 & 465.73 & 828.94 & 727.64 & 691.40 & 427.46 & 405.11 & 416.16 & 1771.94 & 170.12 & 564.90 \\
\hline DG60 & 633.83 & 334.54 & 697.71 & 1045.37 & 1135.93 & 800.21 & 895.25 & 719.69 & 1674.86 & 264.04 & 851.88 \\
\hline DG61 & 889.33 & 1600.22 & 1504.25 & 1098.27 & 1143.32 & 1245.19 & 467.59 & 536.37 & 3215.98 & 1451.88 & 756.22 \\
\hline DG62 & 438.22 & 872.50 & 774.16 & 450.27 & 494.11 & 407.87 & 186.85 & 320.43 & 1783.29 & 498.82 & 267.88 \\
\hline DG65 & 950.64 & 1485.77 & 915.53 & 307.36 & $7 ळ 5.41$ & 324.24 & 742.85 & 858.41 & 1629.47 & 783.48 & 476.53 \\
\hline DG67 & 796.40 & 1217.07 & 844.80 & 460.59 & 518.84 & 361.94 & 486.96 & 590.04 & 1609.24 & 641.03 & 278.80 \\
\hline DG68 & 422.39 & 760.26 & 891.96 & 577.54 & 485.68 & 428.78 & 243.69 & 360.86 & 2223.76 & 321.95 & 503.66 \\
\hline DG69 & 247.34 & 522.95 & 518.10 & 317.74 & 586.91 & 330.72 & 172.51 & 172.86 & 1708.84 & 308.69 & 304.48 \\
\hline DG70 & 778.55 & 596.08 & 513.74 & 405.65 & 1075.96 & 181.30 & 758.76 & 686.48 & 906.84 & 284.76 & 458.61 \\
\hline DG71 & 3570.81 & 1787.17 & 3269.11 & 4040.59 & 5974.10 & 4156.15 & 4289.45 & 3370.76 & 3175.49 & 3045.55 & 3908.75 \\
\hline DG73 & 1069.65 & 494.45 & 705.93 & 959.37 & 2296.84 & 1127.70 & 1592.86 & 1131.11 & 1197.10 & 836.35 & 1206.66 \\
\hline DG111 & 1142.55 & 1170.00 & 1303.77 & 1374.14 & 564.16 & 790.08 & 1017.89 & 1242.33 & 2261.99 & 364.03 & 1080.70 \\
\hline DG112 & 450.95 & 770.37 & $8 \varpi 3.19$ & 720.51 & 524.52 & 510.55 & 218.49 & 304.20 & 2112.90 & 446.46 & 432.53 \\
\hline DG113 & $\llbracket 0.73$ & 601.60 & 600.49 & 565.66 & 710.00 & 255.39 & 679.71 & ๔4.19 & 1370.51 & 140.86 & 525.49 \\
\hline DG 114 & 0.00 & జ33.ఝె & 572.37 & 598.85 & 786.58 & 789.76 & 340.55 & 219.04 & 2615.51 & 594.47 & 729.69 \\
\hline DG115 & జ3.ఝ3 & 0.00 & 506.21 & 925.57 & 1713.09 & 1015.94 & 983.52 & 554.79 & 1436.11 & 434.78 & 766.70 \\
\hline DG116 & 572.37 & 506.21 & 0.00 & 346.29 & 1449.81 & 59.75 & 857.83 & 481.06 & 1254.19 & 713.41 & 523.58 \\
\hline DG117 & 598.85 & 925.57 & 346.29 & 0.00 & 926.13 & 275.90 & 542.34 & 497.97 & 1402.43 & 691.39 & 347.55 \\
\hline DG118 & 786.58 & 1713.69 & 1449.81 & 926.13 & 0.00 & 579.36 & 441.51 & 945.55 & 3018.39 & 712.92 & 847.71 \\
\hline DG119 & 789.76 & 1015.94 & 659.75 & 275.90 & 579.36 & 0.00 & 500.32 & 680.09 & 1272.00 & 407.57 & 389.20 \\
\hline DG 120 & 340.55 & & & 542.34 & 441.51 & 500.32 & 0.00 & 218.82 & & $6 \infty 3.71$ & 485.16 \\
\hline DG121 & 219.04 & 554.79 & 481.06 & 497.97 & 945.55 & 680.09 & 218.82 & 0.00 & 2134.53 & 644.12 & 458.68 \\
\hline DG122 & 2615.51 & 1436.11 & 1254.19 & 1402.43 & 3018.39 & 1272.00 & 2510.59 & 2134.53 & 0.00 & 1481.92 & 1146.51 \\
\hline DG123 & 594.47 & 434.78 & 713.41 & 691.39 & 712.92 & 407.57 & 663.71 & 644.12 & 1481.92 & 0.00 & 590.89 \\
\hline DG124 & 729.69 & 766.70 & 523.58 & 347.55 & 847.71 & 39.20 & 485.16 & 458.68 & 1146.51 & 593.89 & 0.00 \\
\hline DG 12 & 480.51 & 334.86 & 561.91 & 577.77 & 817.58 & 519.46 & 472.60 & 340.52 & 1368.22 & 203.30 & 276.45 \\
\hline DG126 & 422.00 & 465.85 & 296.26 & 586.09 & 1062.32 & & & & & 517.78 & 701.57 \\
\hline DG127 & 1284.51 & 991.19 & ๙36.89 & 476.20 & 1285.15 & 351.25 & 1164.34 & 1056.69 & 691.75 & 606.96 & 434.35 \\
\hline & 1419.76 & 1000.19 & 650.76 & 470.82 & 1495.15 & & 1265.22 & 1174.53 & 410.85 & & 459.57 \\
\hline DG129 & 874.21 & 622.26 & 484.83 & 370.63 & 1170.99 & 378.98 & 878.59 & 993.78 & $6 \infty 9.81$ & 411.11 & 221.40 \\
\hline DG130 & 699.24 & 808.69 & & 275.17 & 741.89 & 355.43 & 474.73 & 452.10 & 1302.10 & 565.28 & 148.81 \\
\hline DG131 & & & & & & 523.07 & 1495.76 & & 530.81 & 1082.71 & 565.88 \\
\hline DG132 & 991.13 & 1386.43 & 805.92 & 362.86 & 591.03 & 211.36 & $7 \pi 9.01$ & 951.49 & 1378.89 & 623.23 & 382.08 \\
\hline DG133 & & 795.26 & 507.28 & 356.62 & 1009.88 & 661.43 & 409.63 & & 2044.16 & 815.70 & 365.67 \\
\hline DG134 & 761.10 & 775.91 & 338.00 & 358.23 & 1205.16 & 535.30 & 757.54 & 544.32 & 1143.67 & 824.40 & 321.75 \\
\hline DG138 & 647.68 & 531.91 & 1121.85 & 1215.10 & 963.77 & 845.97 & 759.92 & 759.95 & 2269.30 & 238.02 & 1117.40 \\
\hline MANT & 430.73 & 1157.74 & 1254.33 & 973.75 & 329.64 & 798.99 & 260.27 & 467.05 & 3226.12 & 628.15 & 832.49 \\
\hline
\end{tabular}


Tabela 45. Distância Generalizada de Mahalanobis entre as etnovariedades. Continuação.

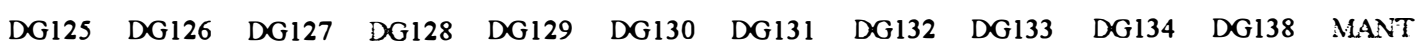

\begin{tabular}{|c|c|c|c|c|c|c|c|c|c|c|c|c|}
\hline & 1091.45 & 1324.94 & 689.70 & 581.77 & 610.75 & 666.81 & 583.64 & 593.07 & 738.92 & 815.32 & 2119.38 & 1629.12 \\
\hline DG39 & 313.22 & 711.18 & 562.06 & 744.93 & 455.07 & & & & & ๔3.41 & & 427.82 \\
\hline DG40 & 240.02 & ஐ2.82 & 811.30 & 790.16 & 471.25 & 519.89 & 1202.46 & 6.71 & & & & 425.60 \\
\hline G41 & & 736.15 & 687.05 & 600.21 & 363.89 & 466.85 & & 494.11 & & & & 670.90 \\
\hline G42 & 507.52 & 374.57 & $\pi 72.60$ & $\pi 7.46$ & 527.41 & & & & & 55.24 & & 712.70 \\
\hline G43 & 532.68 & 257.53 & 1151.92 & 1254.81 & 806.86 & 506.30 & 1576.00 & & & & & \\
\hline 344 & 709.14 & 214.44 & 958.75 & 828.64 & $\widetilde{\sigma} 27.93$ & 641.58 & 1375.72 & 817.98 & 865.39 & 526.49 & 913.00 & 1200.78 \\
\hline DG45 & 914.96 & 1260.55 & 1303.36 & 1751.20 & 1284.49 & 1075.94 & 1729.77 & 998.98 & 688.01 & 1682.61 & 1283.47 & 680.86 \\
\hline DG46 & 656.39 & 802.18 & 1029.06 & 883.81 & & 1194.24 & 1350.02 & 1473.66 & & 1066.13 & & 1550.37 \\
\hline G47 & 243.09 & 517.82 & 528.48 & 482.50 & 249.24 & 316.95 & 883.86 & & 666.19 & & 726.83 & 847.53 \\
\hline 348 & 289.92 & 594.07 & 739.96 & 699.66 & & 490.80 & & & & & & \\
\hline G49 & 348.91 & 718.98 & 870.89 & 984.96 & 653.04 & 647.41 & 1228.95 & & & & & \\
\hline G50 & 341.91 & 688.77 & 745.78 & 879.12 & 624.42 & 557.44 & 1211 & 534.07 & & & & 455.69 \\
\hline 351 & 250.17 & 602.20 & 919.26 & 1082.47 & 713.08 & 680.46 & 1528.81 & & & & & 406.17 \\
\hline 552 & 207.23 & 700.37 & 478.51 & 563.52 & & 328.35 & & 433.09 & & & & 621.35 \\
\hline 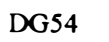 & 853.28 & 1162.10 & 1384.14 & 1069.17 & & 1371.71 & 1644.47 & 1500.79 & 147 & & & \\
\hline 5 & 442.55 & ๔38.06 & 722.43 & 497.96 & 324.17 & 663.34 & 919.76 & & & & .92 & 1115.40 \\
\hline 556 & & 784.02 & 1261.35 & 1500.00 & & 669.68 & 176 & & & & & \\
\hline & 320.44 & 864.09 & & 1584.45 & & & & 113 & & & & \\
\hline 9 & & 585.72 & 810.88 & 892.09 & & 506.83 & 1271.55 & & & & & 34 \\
\hline & 422.46 & 465.53 & 1124 & 1070.87 & & 891.99 & 162 & 112 & & & & \\
\hline & 841.67 & 1558.37 & 1593 & 1979.76 & & & 188 & & & & & 626.74 \\
\hline 6 & & 776.24 & 826 & 852.71 & & & 105 & & & & & \\
\hline & & 1063. & & 580.80 & & & & & & & & \\
\hline 6 & & 802 & & & & & & & & & & \\
\hline D & & 722 . & 778.42 & 1037.58 & & & 121 & & & & & \\
\hline & & 481. & 726.82 & $\pi 70.30$ & & & & & & & & 36.54 \\
\hline & 7.26 & 594.47 & 323.89 & 291 & & & & & & & & \\
\hline D & 3060.93 & 3395.07 & 4160.82 & 3579.53 & & 437 & 4507.09 & 515 & 4.10 & & & \\
\hline & & & & & & & & & & & & \\
\hline & & & 1059.54 & 1294 & & & 170 & & & & & \\
\hline & & & & & & & & & & & & \\
\hline & & 482.58 & & & & & & & & & & \\
\hline & & 422.00 & 1284.51 & 141 & & $\infty 9$ & & & & & & \\
\hline & & & & & & & & 138 & & & & \\
\hline & & 296. & & & & & & & & & & \\
\hline & & 586.09 & & & & & & & & & & \\
\hline & & 1062.32 & & 149 & & & & & & & & \\
\hline & & 618.88 & & & & & & & & & & 86.99 \\
\hline & & & & & & & & & & & & \\
\hline & & & $105 x$ & & & & 140 & 951 & & & & .05 \\
\hline & 68.22 & 1815.99 & & & & 130 & 530 & 137 & & & 22 & \\
\hline & & & & & & & & & & & & \\
\hline & & & & & & & & & & & 111 & 832.49 \\
\hline & & & & & & & & & & & & \\
\hline & & & & & & & & & & & & \\
\hline & 4 & 858.2 & & 165.81 & & & & & & & & \\
\hline & & & & & & & & & & & & \\
\hline & & 687.3 & & 201. & & 306. & & 35 & & & 7.06 & 1177.74 \\
\hline & & & & & & & & & & & & \\
\hline & & & & & & & & & & & & \\
\hline & & 869 & 296 & 427.58 & & 309 & & & 686.30 & & & \\
\hline & & & & & & & & & & & & \\
\hline & & 489.64 & & & & & & 558 & 495.54 & 0.00 & 1279.57 & 1122.10 \\
\hline & & & & & & & & & & & 0.00 & 710.06 \\
\hline & & & 1450.82 & 1732.50 & 1177.74 & & 2062.65 & 975.32 & 588.15 & 1122.10 & 710.06 & 0.00 \\
\hline
\end{tabular}


Tabela 46: Média, mínimo e máximo para os componentes quimicos das raizes, caule e folhas das 56 etnovariedades de mandioca avaliadas.

\begin{tabular}{|c|c|c|c|c|c|c|c|c|c|}
\hline \multirow[b]{3}{*}{ Umidade \% } & \multicolumn{3}{|c|}{ Raizes $^{1}$} & \multicolumn{3}{|c|}{ Caule } & \multicolumn{3}{|c|}{ Folhas $^{2}$} \\
\hline & \multirow{2}{*}{$\begin{array}{r}\text { Min. } \\
53,4\end{array}$} & Med. & Max. & Min. & Med. & Max. & Min. & Med. & Max. \\
\hline & & 62,5 & 76,1 & 55,2 & 64,0 & 72.3 & 56.2 & 66,2 & 75,3 \\
\hline \multicolumn{10}{|l|}{$\%$ M. Seca } \\
\hline Proteína & 1,26 & 2,63 & 5.31 & 1.86 & $\mathbf{5 , 0 7}$ & 8.76 & 18.66 & 24,40 & 28,67 \\
\hline Carboidrato & & & & 26,92 & 32,28 & 37,87 & 7.19 & 15,76 & 21,96 \\
\hline Amido & 79,43 & 88,12 & 90,64 & & & & & & \\
\hline Açucar Sol. & 1,14 & 1,70 & 1,96 & & & & & & \\
\hline M. Graxa & 0,66 & 0,85 & 0,99 & 0,61 & 1,50 & 1,97 & 4,87 & 6,70 & 10,37 \\
\hline Cinzas & 1,33 & 2,37 & 4,73 & 2,79 & 5,10 & 8,45 & 5,37 & 7,42 & 10,87 \\
\hline Fibras & 2,51 & 4,09 & 7,70 & 43,73 & 53,33 & 62,88 & 14,34 & 17,88 & 23,10 \\
\hline $\mathrm{HCN}^{p(3)}$ & 8,41 & 30,769 & 89,45 & & & & 393,0 & 1105,0 & 2017,0 \\
\hline $\mathrm{HCN}^{\mathrm{L}(3)}$ & 0,913 & 2,998 & 7,807 & & & & 44,2 & 192,7 & 389,3 \\
\hline
\end{tabular}

1: raiz: sem casca. No caso $\mathrm{HCN}$, raiz sem casca e entrecasca (polpa)

2: folha sem pecíolo 